\title{
Secreted glycoproteins and proteoglycans orchestrate inflammation in cardiac disease
}

Citation for published version (APA):

Rienks, M. (2016). Secreted glycoproteins and proteoglycans orchestrate inflammation in cardiac disease. [Doctoral Thesis, Maastricht University]. Maastricht University. https://doi.org/10.26481/dis.20160226mr

Document status and date:

Published: 01/01/2016

DOI:

10.26481/dis.20160226mr

Document Version:

Publisher's PDF, also known as Version of record

\section{Please check the document version of this publication:}

- A submitted manuscript is the version of the article upon submission and before peer-review. There can be important differences between the submitted version and the official published version of record.

People interested in the research are advised to contact the author for the final version of the publication, or visit the DOI to the publisher's website.

- The final author version and the galley proof are versions of the publication after peer review.

- The final published version features the final layout of the paper including the volume, issue and page numbers.

Link to publication

\footnotetext{
General rights rights.

- You may freely distribute the URL identifying the publication in the public portal. please follow below link for the End User Agreement:

www.umlib.nl/taverne-license

Take down policy

If you believe that this document breaches copyright please contact us at:

repository@maastrichtuniversity.nl

providing details and we will investigate your claim.
}

Copyright and moral rights for the publications made accessible in the public portal are retained by the authors and/or other copyright owners and it is a condition of accessing publications that users recognise and abide by the legal requirements associated with these

- Users may download and print one copy of any publication from the public portal for the purpose of private study or research.

- You may not further distribute the material or use it for any profit-making activity or commercial gain

If the publication is distributed under the terms of Article $25 \mathrm{fa}$ of the Dutch Copyright Act, indicated by the "Taverne" license above, 


\section{Secreted Glycoproteins and Proteoglycans Orchastrate Inflammation in Cardiac Disease}




\section{Cover design Marieke Rienks}

De combinatie van analytsisch denkvermogen en creativiteit komt nergens zo tot zijn recht als in de wetenschap. Deze cover illustreert niet alleen deze prachtige synergie maar geeft daarnaast ook een abstracte weergave van de fascinerende extracellulaire matrix in het hart. Waar deze thesis is begonnen zonder dat zijn uiteindelijke bestemming gekend was, zo ook is dit schilderij ontstaan. Art meets science. Ontdekken zonder doel. Gemaakt van olieverf op doek.

The research described in this thesis was supported by the European Commission's Seventh Framework programme under grant agreement $\mathrm{N}^{\circ} 305507$ (HOMAGE), N 305507 (FIBROTARGETS) and $\mathrm{N}^{\circ} 261409$ (MEDIA), and the Marie-Curie Industry. It was further supported by research grants from the Netherlands Organization for Scientific Research (NWO) VIDI 91796338 (dr. Heymans). We acknowledge the support from the Netherlands Cardiovascular Research Initiative: the Dutch Heart Foundation, the Dutch Federation of University Medical Centers, the Netherlands Organization for Health Research and Development and the Royal Netherlands Academy of Sciences (CVON 2011-11 ARENA). Also, financial support for the publication of this thesis by Bayer Health Care and Rescar Hartsvrienden Foundation Maastricht is gratefully acknowledged.

\section{Copyright (C) 2016 by Marieke Rienks}

All rights reserved. No part of the material protected by this copyright notice may be reproduced or utilized in any form or by any means, electronic or mechanical, including photocopying, recording or by any information storage and retrieval system, without the prior permission of the author.

Printed by proefschridtmaken.nl, 's-Hertogenbosch, the Netherlands 


\section{Secreted Glycoproteins and Proteoglycans Orchastrate Inflammation in Cardiac Disease}

\section{PROEFSCHRIFT}

ter verkrijging van de graad van doctor aan de Universiteit Maastricht op gezag van de Rector Magnificus, Prof. dr. L.L.G. Soete, volgens het besluit van het College van Decanen in het openbaar te verdedigen op vrijdag 26 februari 2016 om 12.00 uur

MARIEKE RIENKS, MD

Maastricht University, Maastricht, Nederland geboren te Leeuwarden, Nederland 


\section{Promotor}

Prof. dr. S. Heymans

\section{Copromotor}

Dr. A.P. Papageorgiou

\section{BEOORDELINGSCOMMISSIE}

Prof. dr. C. Schalkwijk (voorzitter)

Prof. Dr. T.M. Hackeng

Dr. P. van Paassen

Prof. dr. M. Mayr, King's College London, England

Prof. dr. M.J.Th.H. Goumans, Leids Universitair Medisch Centrum, Nederland 


\section{Contents}

$\begin{array}{lll}\text { CHAPTER } 1 \quad \text { General Introduction } & 7\end{array}$

$\begin{array}{lll}\text { Chapter } 2 \text { The Immune System } & 15\end{array}$

Chapter 3 The Myocardial Extracellular Matrix: an

Ever Changing and Diverse Entity 29

Chapter 4 A novel 72-kDa Leukocyte-Derived Osteoglycin

Enhances the Activation of Toll-Like Receptor 4

and Exacerbates Cardiac Inflammation during

Viral Myocarditis

65

Chapter 5 The Extracellular Matrix Protein SPARC is Crucial in Maintaining Endothelial

Barrier Function and Prevents Adverse

Cardiac Inflammation

87

Chapter 6 Semaphorin 3A Promotes the Resolution of Cardiac Inflammation after Myocardial Infarction

Chapter 7 Discussion

SumMary

SAMENVATTING 137

VALORIZATION

Nonstandard AbbreViations ANd ACronyms 147

DANKWOORD 151

Curriculum Vitae 157

$\begin{array}{ll}\text { Publication List } & 161\end{array}$ 
Heart failure (HF) is major public health issue affecting over 20 million people globally and remains the number one cause of death in the world ${ }^{1}$. The first longitudinal studies examining cardiovascular disease began during the fifties in the United States and resulted in the Framingham and Olmsted county cohorts ${ }^{2,3}$. This led to the finding that the incidence of HF increases with age in both North America and Europe ${ }^{4,5}$, and is getting more pronounced. Indeed, a recent American Heart Association report stated that HF is a chronic condition currently affecting over 5.7 million people in the United States and costing around 30.7 billion dollar every year ${ }^{6}$. These numbers will rise to an estimated 8 million affected individuals costing approximately 70 billion dollars by 2030 , emphasizing the immense societal burden of this disease. European studies reveal similar annual health care expenditure on HF patients ${ }^{7,8}$ with a rising incidence to $10-22$ per 1000 for people over 65 years of age ${ }^{9-11}$.

HF is a clinical syndrome diagnosed according to the guidelines defined by the European Society for HF in $2012^{12}$.It is characterized by either an abnormal structure or function of the heart at rest, with typical clinical symptoms like shortness of breath at rest or during exertion, fatigue and fluid retention such as pulmonary congestion or peripheral edema ${ }^{12}$. These clinical symptoms together with electrocardiogram, laboratory testing and echocardiography help in determining appropriate therapeutic strategy and also provide substantial prognostic information. The current standard for treating HF patients, consisting of ACE-inhibitors, diuretics, $\beta$-blockers and mineralocorticoid-receptor antagonist (MRA) mainly focus on fighting clinical symptoms without having any evident effect of the underlying pathophysiology. Because HF is such a complex syndrome where many underlying etiologies may affect pericardium, myocardium, endocardium, cardiac valves, vasculature, or metabolism, the identification of new effective therapies has been very challenging these past decades ${ }^{13}$. As a result, the prognosis of HF is still poor, underlining the clinical need for drugs designed for improving clinical outcome ${ }^{14}$. The major challenge here is identifying the pathophysiological mechanisms that contribute to the development of HF, triggering either systolic or diastolic dysfunction. This distinction is critical as they require a different pharmacological approach despite their similar clinical presentation ${ }^{15}$. Where systolic HF is characterized by reduced ejection fraction on echocardiography (contraction incapacities; left ventricular ejection fraction EF $\leq 40$ percent; HEFrEF), the ejection fraction in diastolic dysfunction is preserved (relaxation incapacities; meaning a left ventricular EF $\geq 50$ percent; HEFpEF) ${ }^{13}$. Though etiology does not allow for proper discrimination, risk factors like increased age ${ }^{16}$ and gender are more observed in HEFpEF patient populations $(\approx 80 \%$ woman in HEFpEF with $\approx 50 \%$ in HEFrEF ${ }^{17-19}$ ) (Figure 1). While the extent of pathophysiological overlap between these syndromes needs to be properly established, studies have already revealed that many shared triggers lead to several shared fundamental pathophysiological changes such as cardiomyocyte death, cardiomyocyte hypertrophy, cardiac inflammation followed by (reactive) fibrosis. Whilst the contributions of inflammation and reactive fibrosis are established for systolic $\mathrm{HF}^{20-22}$, they are only starting to become recognized in the pathogenesis of diastolic $\mathrm{HF}^{23,24}$.

Systolic heart failure is the result of coronary (ischemic) heart disease, idiopathic dilated cardiomyopathy (DCM), hypertension or valvular disease. While myocardial infarction is the most common cause for the development of $\mathrm{HF}^{25}$, it is closely followed by idiopathic DCM. Interestingly, in DCM misdiagnosing is quite common ${ }^{26,27}$ as about 10 percent of these patients actually suffer from myocarditis ${ }^{28}$. Though, the true incidence of myocarditis is unknown because of sporadic endo-myocardial biopsy collection and the overall difficulty 
to diagnose this disease ${ }^{29}$, it still remains a serious cause for HF development particularly in previously healthy individuals, with guidelines for diagnosis and treatment still lacking ${ }^{30}$.

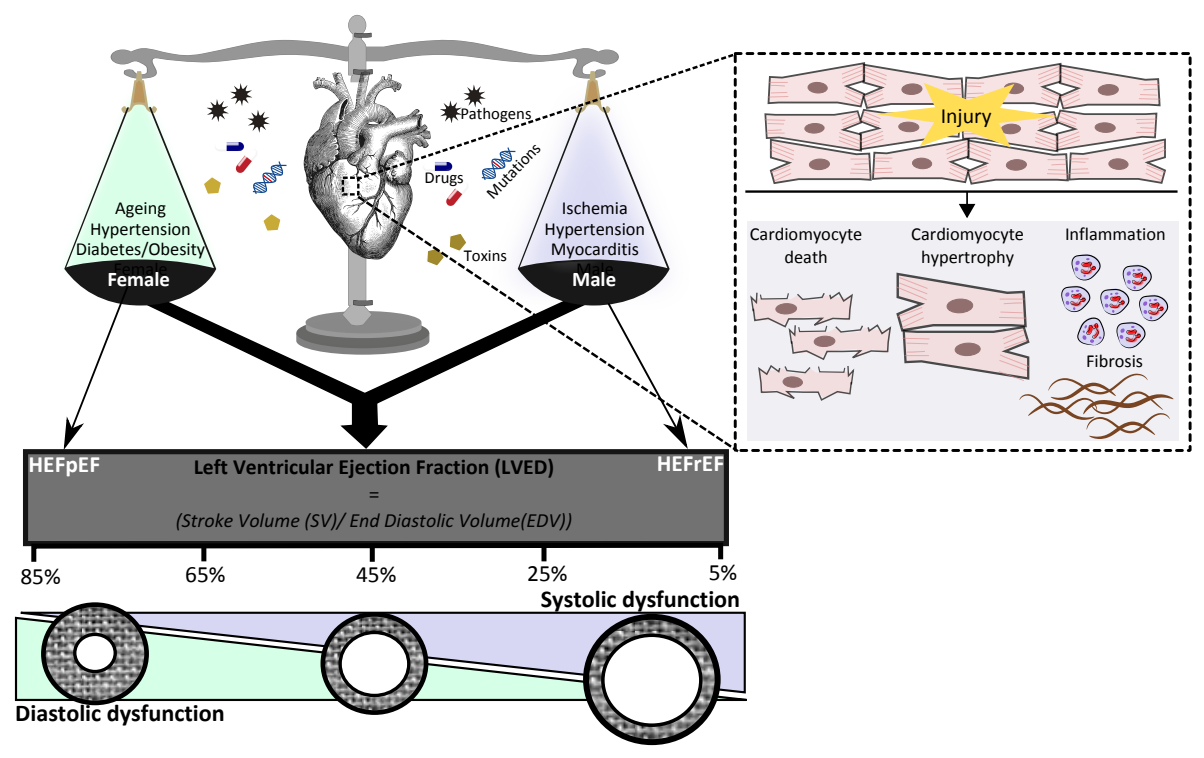

Figure 1 This schematic OVerview illustrates the complexity of the heart failure syndrome. Many triggers like drugs, toxins, pathogens and mutations can result in damage to the myocardium. This damage will lead to four pathophysiological changes that advocate cardiac remodeling and subsequent heart failure development: cardiomyocyte death, inflammation, fibrosis and cardiomyocyte hypertrophy. The combination of environmental triggers with genetic mutations or genetic susceptibly, such as gender or ageing, can further promote cardiac damage and heart failure development. Finally, added existence of comorbidities will enhance the ongoing changes in the myocardium. Where some risk factor like diabetes, obesity and female gender are more associated with the development of HEFpEF, others such as cardiac ischemia, myocarditis or male gender have been shown to be more associated with the development of HEFrEF. Though, all triggers can cause the development of the entire range of heart failure, which is characterized by the morphological appearance of the heart as well as the functional characteristics (LVEF). HEFPEF : Heart Failure with preserved Ejection Fraction, HEFrEF : Heart Failure with reduced Ejection Fraction. 


\section{Aim and Outline of this Thesis}

The main aim of this thesis is to unravel the role of the extracellular environment to cardiac inflammation during HF development. The pathophysiological contribution of secreted proteins osteoglycin, SPARC and semaphorin $3 \mathrm{~A}$ on the development and maintenance of cardiac inflammation as a consequence of viral myocarditis or myocardial infarction will be addressed.

Chapter 1 gives a concise introduction to the functions of the immune system. The basic innate and adaptive immune response towards pathogens will be discussed and provide the necessary background for understanding how the immune system contribution to HF development. Chapter 2 will elaborate on how the extracellular compartment in the myocardium can have diverse, and sometimes opposing, functions in cardiac disease. Not only the composition and plasticity will be discussed, also the current knowledge on the role of several individual proteins in cardiac inflammation and fibrosis will be addressed. Chapter 3, 4 and 5 will reveal experimental evidence of three individual extracellular proteins that regulate cardiac inflammation either during virus or ischemia induced cardiac disease. These chapters will demonstrate the role of the extracellular milieu in regulating cardiac inflammation through either affecting (1) immune cell activation, (2) recruitment, (3) immune cell resolution; the pillars of immunity. The value of these findings to our current knowledge of the immune system as well as its clinical utility for HF patients will be addressed in Chapter 6 . 


\section{REFERENCES}

$1 \quad$ Murphy SL, Xu J, Kochanek KD. Deaths: Final data for 2010. Natl Vital Stat Rep. 2013;61:1-117

2 McKee PA, Castelli WP, McNamara PM, Kannel WB. The natural history of congestive heart failure: The framingham study. N Engl J Med. 1971;285:1441-1446

3 Senni M, Tribouilloy CM, Rodeheffer RJ, Jacobsen SJ, Evans JM, Bailey KR, Redfield MM. Congestive heart failure in the community: A study of all incident cases in olmsted county, minnesota, in 1991. Circulation. 1998;98:2282-2289

4 Eriksson H, Svardsudd K, Larsson B, Ohlson LO, Tibblin G, Welin L, Wilhelmsen L. Risk factors for heart failure in the general population: The study of men born in 1913. Eur Heart J. 1989;10:647656

5 Guha K, McDonagh T. Heart failure epidemiology: European perspective. Curr Cardiol Rev. 2013;9:123-127

6 Mozaffarian D, Benjamin EJ, Go AS, Arnett DK, Blaha MJ, Cushman M, de Ferranti S, Despres JP, Fullerton HJ, Howard VJ, Huffman MD, Judd SE, Kissela BM, Lackland DT, Lichtman JH, Lisabeth LD, Liu S, Mackey RH, Matchar DB, McGuire DK, Mohler ER, 3rd, Moy CS, Muntner P, Mussolino ME, Nasir K, Neumar RW, Nichol G, Palaniappan L, Pandey DK, Reeves MJ, Rodriguez CJ, Sorlie PD, Stein J, Towfighi A, Turan TN, Virani SS, Willey JZ, Woo D, Yeh RW, Turner MB. Heart disease and stroke statistics--2015 update: A report from the american heart association. Circulation. 2015;131:e29322

7 Liao L, Allen LA, Whellan DJ. Economic burden of heart failure in the elderly. Pharmacoeconomics. 2008;26:447-462

8 Mant J, Al-Mohammad A, Swain S, Laramee P, Guideline Development G. Management of chronic heart failure in adults: Synopsis of the national institute for health and clinical excellence guideline. Ann Intern Med. 2011;155:252-259

9 Murphy NF, Simpson CR, McAlister FA, Stewart S, Maclntyre K, Kirkpatrick M, Chalmers J, Redpath A, Capewell S, McMurray JJ. National survey of the prevalence, incidence, primary care burden, and treatment of heart failure in scotland. Heart. 2004;90:1129-1136

10 Cowie MR, Wood DA, Coats AJ, Thompson SG, Poole-Wilson PA, Suresh V, Sutton GC. Incidence and aetiology of heart failure; a population-based study. Eur Heart J. 1999;20:421-428

11 de Giuli F, Khaw KT, Cowie MR, Sutton GC, Ferrari R, Poole-Wilson PA. Incidence and outcome of persons with a clinical diagnosis of heart failure in a general practice population of 696,884 in the united kingdom. Eur J Heart Fail. 2005;7:295-302

12 McMurray JJ, Adamopoulos S, Anker SD, Auricchio A, Bohm M, Dickstein K, Falk V, Filippatos G, Fonseca C, Gomez-Sanchez MA, Jaarsma T, Kober L, Lip GY, Maggioni AP, Parkhomenko A, Pieske BM, Popescu BA, Ronnevik PK, Rutten FH, Schwitter J, Seferovic P, Stepinska J, Trindade PT, Voors AA, Zannad F, Zeiher A, Task Force for the D, Treatment of A, Chronic Heart Failure of the European Society of C, Bax JJ, Baumgartner H, Ceconi C, Dean V, Deaton C, Fagard R, Funck-Brentano C, Hasdai D, Hoes A, Kirchhof P, Knuuti J, Kolh P, McDonagh T, Moulin C, Popescu BA, Reiner Z, Sechtem U, Sirnes PA, Tendera M, Torbicki A, Vahanian A, Windecker S, McDonagh T, Sechtem U, Bonet LA, Avraamides P, Ben Lamin HA, Brignole M, Coca A, Cowburn P, Dargie H, Elliott P, Flachskampf FA, Guida GF, Hardman S, lung B, Merkely B, Mueller C, Nanas JN, Nielsen OW, Orn S, Parissis JT, Ponikowski P, Guidelines ESCCfP. Esc guidelines for the diagnosis and treatment of acute and chronic heart failure 2012: The task force for the diagnosis and treatment of acute and chronic heart failure 2012 of the european society of cardiology. Developed in collaboration with the heart failure association (hfa) of the esc. Eur J Heart Fail. 2012;14:803-869

13 Gupta A, Ghimire G, Hage FG. Guidelines in review: 2013 accf/aha guideline for the management of heart failure. J Nucl Cardiol. 2014;21:397-399

14 Aronson D, Krum H. Novel therapies in acute and chronic heart failure. Pharmacol Ther. 2012;135:117

15 Aronow WS. Drug treatment of systolic and of diastolic heart failure in elderly persons. J Gerontol A Biol Sci Med Sci. 2005;60:1597-1605

16 Zile MR, Brutsaert DL. New concepts in diastolic dysfunction and diastolic heart failure: Part i: Diagnosis, prognosis, and measurements of diastolic function. Circulation. 2002;105:1387-1393

17 Masoudi FA, Havranek EP, Smith G, Fish RH, Steiner JF, Ordin DL, Krumholz HM. Gender, age, and heart failure with preserved left ventricular systolic function. Journal of the American College of Cardiology. 2003;41:217-223

18 Yusuf S, Pfeffer MA, Swedberg K, Granger CB, Held P, McMurray JJ, Michelson EL, Olofsson B, 
Ostergren J, Investigators C, Committees. Effects of candesartan in patients with chronic heart failure and preserved left-ventricular ejection fraction: The charm-preserved trial. Lancet. 2003;362:777-781

19 Lam CS, Carson PE, Anand IS, Rector TS, Kuskowski M, Komajda M, McKelvie RS, McMurray JJ, Zile MR, Massie BM, Kitzman DW. Sex differences in clinical characteristics and outcomes in elderly patients with heart failure and preserved ejection fraction: The irbesartan in heart failure with preserved ejection fraction (i-preserve) trial. Circulation. Heart failure. 2012;5:571-578

Bouras G, Giannopoulos G, Hatzis G, Alexopoulos D, Leventopoulos G, Deftereos S. Inflammation and chronic heart failure: From biomarkers to novel anti-inflammatory therapeutic strategies. Med Chem. 2014;10:682-699

21 Bozkurt B, Mann DL, Deswal A. Biomarkers of inflammation in heart failure. Heart Fail Rev. 2010;15:331-341

22 Lok DJ, Van Der Meer P, de la Porte PW, Lipsic E, Van Wijngaarden J, Hillege HL, van Veldhuisen DJ. Prognostic value of galectin-3, a novel marker of fibrosis, in patients with chronic heart failure: Data from the deal-hf study. Clin Res Cardiol. 2010;99:323-328

23 Glezeva N, Voon V, Watson C, Horgan S, McDonald K, Ledwidge M, Baugh J. Exaggerated inflammation and monocytosis associate with diastolic dysfunction in heart failure with preserved ejection fraction: Evidence of $\mathrm{m} 2$ macrophage activation in disease pathogenesis. J Card Fail. 2015;21:167-177

24 Chrysohoou C, Pitsavos C, Barbetseas J, Kotroyiannis I, Brili S, Vasiliadou K, Papadimitriou L, Stefanadis C. Chronic systemic inflammation accompanies impaired ventricular diastolic function, detected by doppler imaging, in patients with newly diagnosed systolic heart failure (hellenic heart failure study). Heart Vessels. 2009;24:22-26

25 He J, Ogden LG, Bazzano LA, Vupputuri S, Loria C, Whelton PK. Risk factors for congestive heart failure in us men and women: Nhanes i epidemiologic follow-up study. Arch Intern Med. 2001;161:996-1002

26 Luk A, Metawee M, Ahn E, Gustafsson F, Ross H, Butany J. Do clinical diagnoses correlate with pathological diagnoses in cardiac transplant patients? The importance of endomyocardial biopsy. Can J Cardiol. 2009;25:e48-54

27 Luk A, Metawee M, Ahn E, Gustafsson F, Ross H, Butany J. Do clinical diagnoses correlate with pathological diagnoses in cardiac transplant patients? The importance of endomyocardial biopsy. Can J Cardiol. 2009;25:e48-54

28 Felker GM, Thompson RE, Hare JM, Hruban RH, Clemetson DE, Howard DL, Baughman KL, Kasper EK. Underlying causes and long-term survival in patients with initially unexplained cardiomyopathy. N Engl J Med. 2000;342:1077-1084

29 Esfandiarei M, McManus BM. Molecular biology and pathogenesis of viral myocarditis. Annu Rev Pathol. 2008;3:127-155

30 Magnani JW, Dec GW. Myocarditis: Current trends in diagnosis and treatment. Circulation. $2006 ; 113: 876-890$ 

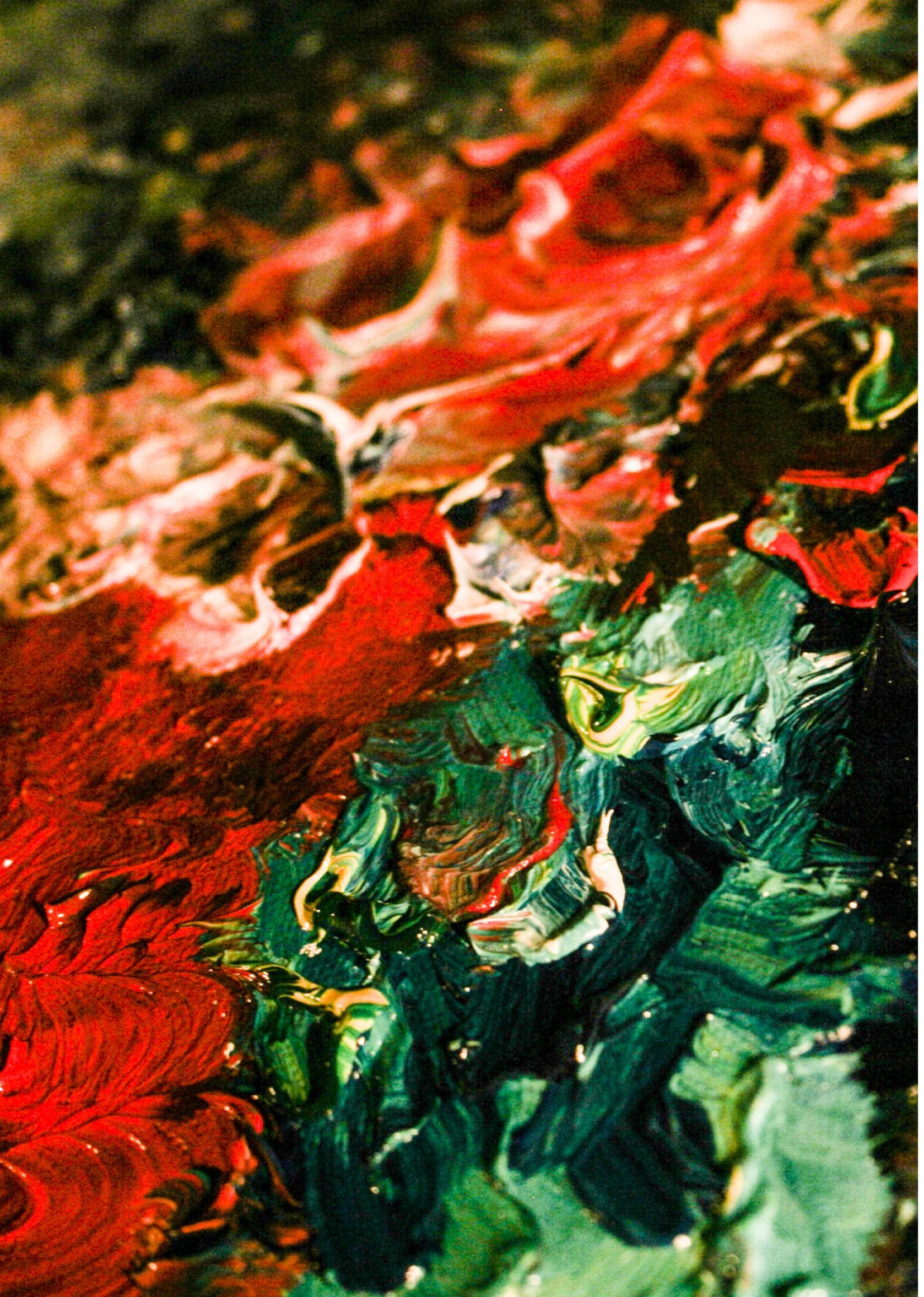


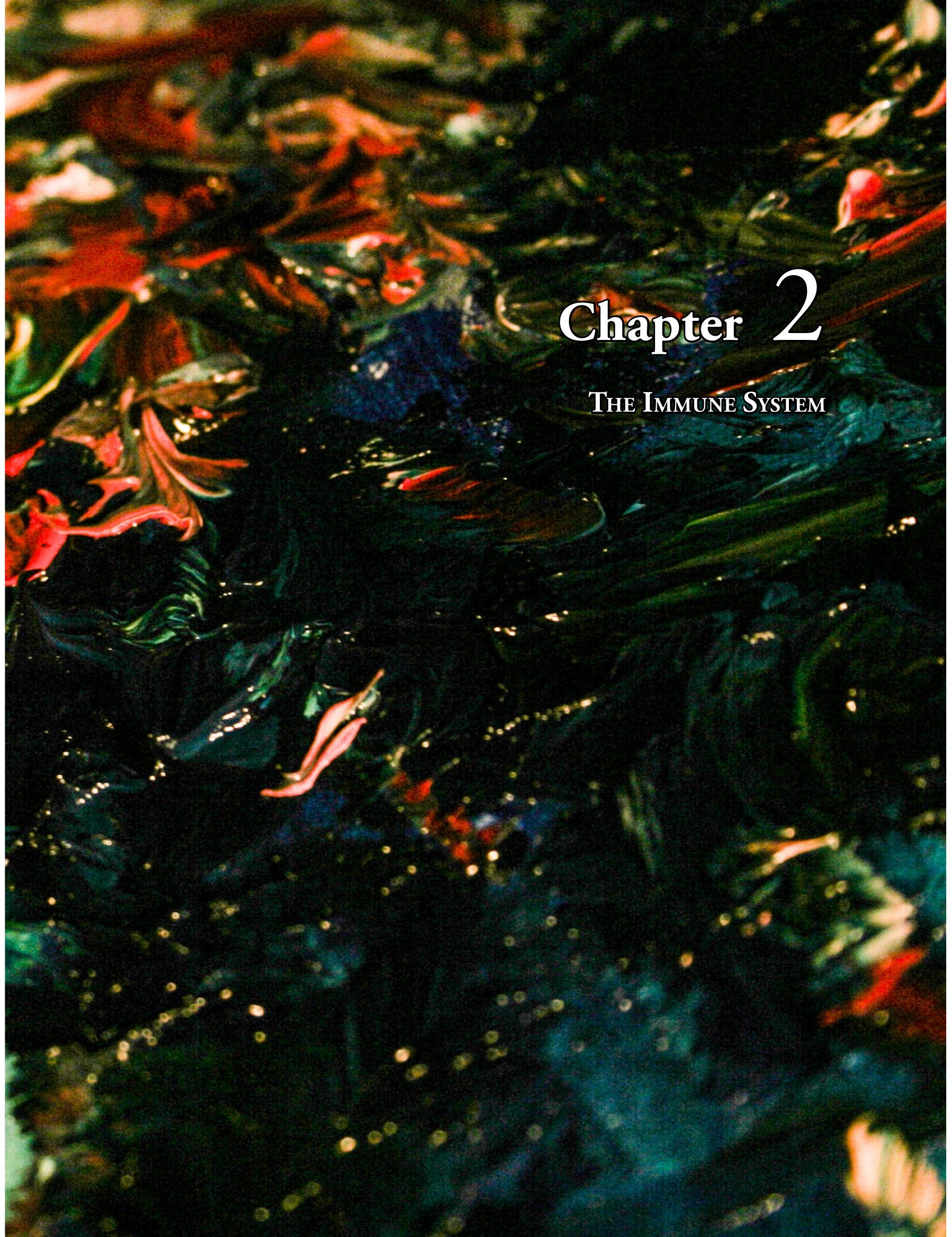




\section{The Equilibrium Compatible with Life}

Homeostasis is one of the fundamental characteristics of any living organism and defines the line between life and death. It implies a situation where all systems within a living organism are in perfect balance and the internal milieu does not change albeit the changing external milieu. Therefore every threat that endangers homeostasis has to be eradicated by the immune system in order to return to a 'steady-state' situation. When dealing with multifaceted human diseases, the many complex pathophysiological processes that occur simultaneously call for the continuous pursuit for a new immunological balance. As immune cells patrol tissues with the purpose of alarming and recruiting other immune cells when homeostasis is compromised, they have to be mobile, fast and effective and most importantly very vigilant of their environment. To better appreciate and comprehend our sophisticated immune system in relation to complex diseases such as heart failure (HF) we should go back to where the immune system originated.

\section{The Evolution of Immunity}

The first described ancestors of the modern immune system are unicellular microorganisms like the amoeba. Amoebas possessed a specific surface receptor that allowed them to distinguish food (micro-organisms) from other amoebas (also micro-organisms). Through an unknown evolutionary mechanism, they developed a basic unicellular immune response which prevented their own extinction ${ }^{1}$. The present innate immune cells such as neutrophils and macrophages, still owe their ontogenesis and phylogenesis to the amoeba. As a consequence of evolutionary changes in the earth's atmosphere from oxygen-poor to oxygen-rich, aerobic metabolism originated producing up to eighteen times more energy than the thus far used anaerobic metabolism. This new source of energy enabled many more biological reactions to take place simultaneously, promoting organelle formation and cell compartmentalization, ensuing the birth of the eukaryotes ${ }^{2}$. However, this shift towards multi-cellularity required the emergence of a more complex system of self-surveillance than that of unicellular organisms, as the detection and removal of altered or damaged 'self' became as important for survival as the necessity to recognize and remove pathogens ${ }^{3}$.

Since the ancient amoeba-like macrophage a large variety of different immune cells have entered the arena, forming the intricate human immune system that we know today. However a unifying feature characterizes innate immunity throughout evolution: the conserved molecular pattern recognition by receptors such as nucleotide-binding oligomerization domain receptors (NOD-like receptors or NLRs), retinoic acid-inducible gene I-like RNA helicases (RIG-I-like receptors or RLRs), C-type lectin receptors (CLRs) and the Toll-Like receptors (TLRs) ${ }^{4,5}$. In fact, extensive genomic analysis of invertebrates, vertebrates, and plants suggests that before separating their routes on the phylogenetic tree, they possessed refined defense mechanisms comprised of the shared Toll pathway ${ }^{6}$. The origination of innate immunity was founded by the discovery of this specific Toll pathway, and encompasses the Toll-like receptors that we know today. As multi-cellular organisms kept evolving, their complexity increased and triggered them to acquire an even more advanced immune system. The rise of adaptive immunity in vertebrates not only enhanced the immune systems response to pathogens, it also created a memory towards them ${ }^{7}$. Though homologue forms of immunoglobulin ${ }^{8}$ and highly diverse lymphocytes with unique anticipatory receptors 9,10 have been found in jawless vertebrates 
(hagfish and lamprey), adaptive immunity is limited to the jawed vertebrates. It is characterized by the presence of a thymus and secondary lymphoid tissues as well as immunoglobulins, T-cell receptors (TCRs) and polymorphic major histocompatibility complex (MHC) class I and class II molecules ${ }^{11,12}$.

\section{Self/Non-Self versus Danger}

As keepers of general homeostasis, the immune system must be primed and respond quickly to anything endangering the precious balance. For many years the precept on what would alarm the immune system in case of danger has been 'non-self'. This perception is easily supported when thinking of the main threat of our unicellular ancestors in their struggle for life, which are pathogens. However, when considering intricate multi-cellular organisms like human and complicates diseases like HF, this belief may fall short. Therefore, not long ago the dictum was challenged by a novel perception stating that it is not 'non-self' but rather 'danger' that sets the alarm. Was this the beginning of an ongoing revolution in the world of immunology?

While the conceptual foundation for the 'self' versus 'non-self' theory was made by Ellie Metchnikoff ${ }^{13}$, the theory was established by Macfarlane Burnet and Peter Medawar ${ }^{14}$, for which they received the Nobel Prize in $1960^{15}$. The theory assumes that from birth multicellular organisms know what 'self' looks like and only attack what they have not seen before. This explains how foreign pathogens are recognized and eliminated and is perfectly in line with the unicellular immune response observed in the amoeba. However, several problems with this theory surfaced in the nineties and entailed basic concerns regarding cancer, transplant surgery and physiological changes like puberty and pregnancy ${ }^{16}$. If the immune system only tolerates what it has encountered in neonatal life then all new 'self' antigens, endogenous or exogenous, should be eliminated. However, in reality the immune system develops a specific immune response towards certain new 'self' antigens while tolerating others. This hiatus was the core for Polly Matzinger to formulate a new theory centralizing 'danger' instead of 'non-self' as the driving force behind immunity ${ }^{16}$. Rather than responding to 'non-self', the immune system gets alarmed by 'danger-signals' that are coming from stressed or necrotic cells, and not form the invading pathogen. While this theory seems very plausible, similar shortcomings are present given that bacterial LPS, bacterial DNA and mimics of viral RNA can activate the immune system without directly causing cell damage ${ }^{17}$. The 'self' versus 'non-self' theory may not be false; it may just be that the definition for 'self' and 'non-self' needs to be refined. On the other hand, if we accept that the immune system has been stitched together throughout evolution and uses a diverse collection of innate and adaptive defense mechanisms, it may be impossible to explain immunity within one 'theory' or another. Furthermore explaining the multifaceted immune system by one single paradigm is an oversimplification as each organ identifies and responds differently to approaching danger based on their relative sterility ${ }^{18}$. As a result, not only the location of sentinel cells can differ, also their activation threshold and PRR expression profiles may vary between organs ${ }^{19,20}$. Finally, besides using the shared TLRs for detecting environmental changes, each organ utilizes additional yet specialized innate immune instruments and regulatory mechanisms ${ }^{21}$. Pluralistic approaches therefore seem inescapable when dealing with human immunity. 


\section{INNATE VERSUS AdAptive IMMUNity}

The primal innate immune system establishes the first line of defense against pathogens in metazoans, playing a vital role in early pathogen recognition and removal and the subsequent pro-inflammatory responses. Instead, the adaptive immune system is responsible for eliminating pathogens in the later phase of infection and in the generation of immunological memory. Where the adaptive immune response is characterized by specificity created by clonal gene rearrangements from a broad repertoire of antigen-specific receptors on lymphocytes, the innate immune response is considered as rather nonspecific and is controlled primarily by phagocytic cells and antigen-presenting cells, such as macrophages, neutrophils and dendritic cells ${ }^{1,22}$. However due to the close relations between adaptive and innate immune, the classification is rather artificial (Figure 1).

\section{Detecting Threats: Pattern Associated Recognition}

Molecular pattern recognition by the innate immune system comprises a family of fairly universal and well-conserved receptors (pattern recognition receptors or PRRs) that recognize repeating patterns in common and well-conserved ligands. These receptors detect pathogenassociated molecular patterns (PAMPs) but also recognize molecules that are produced as a result of tissue injury; the aptly named damage associated molecular pattern molecules (DAMPs) (Figure 1). This places the detection and removal of damaged 'self' equally as important as the recognition and removal of pathogens. These high affinity, low specificity innate immune receptors (e.g. CLRs, RLRs, NLRs and TLRs) are comprised of protein domains that are specific for the type of ligand they recognize. Most classes of human pathogens are recognized by the carbohydrate-recognition domains in the transmembrane or secreted CLRs, as they recognize highly complex structures composed of carbohydrate residues ${ }^{23}$. Importantly, as both pathogen and host can contain carbohydrate residues, it has been observed that these receptors are capable of detecting intricate differences in the arrangement and branching of carbohydrate residues which is the direct result of differential protein glycosylation ${ }^{24}$. Furthermore, RLRs recognize double stranded RNA, the replication intermediate of RNA viruses, via their C-terminal domain and helicase domain ${ }^{25}$. Transmembrane TLRs and cytoplasmic NLRs recognize molecular patterns from a fundamentally diverse collection of bacterial, fungal, viral and parasite-derived elements but also degradation products of extracellular matrix proteins via their leucine rich repeat (LRR) domain ${ }^{26,27,28}$. The LRR domains are common to proteins associated with innate immunity in many phylogenetically distant lineages (e.g. prokaryotes versus eukaryotes) ${ }^{29,30}$. In jawless vertebrates, they even form the foundation of the adaptive immune response as the combinatorial assembly of LRR gene segments in adaptable lymphocyte receptors creates the physical diversity for antigen recognition ${ }^{10,31}$. These LRRs are important for protein-protein interactions and have been found in over two hundred different proteins, including bacterial virulence factors, cell-adhesion molecules, enzymes, hormone receptors, tyrosine kinase receptors and extracellular matrix binding proteoglycans and glycoproteins ${ }^{32}$, ${ }^{33}$. However, the evolution of LRRs is not well understood and it is not even known whether all LRRs share a common ancestor ${ }^{34}$. Currently mutations or polymorphisms in over thirty LRRgenes have been implicated in human diseases with inflammatory components, e.g. frameshift mutations in NOD2 in Crohn disease ${ }^{35,36}$, e.g. polymorphisms in the MHC class II transactivator (MHC2TA) in rheumatoid arthritis, multiple sclerosis and myocardial infarction ${ }^{37}$ and mutation in TLR5 in Legionnaire disease ${ }^{38}$. 


\section{The Innate Response: Complement and Phagocytosis}

The fast elimination of pathogens is primarily based on PRR-induced immune activation, complement activation and phagocytosis. All metazoans possess one of the earliest and universal elements of innate immunity that is mucosal epithelia. Mucosal epithelia is vital in protecting the host from invasion as well as in establishing a symbiotic relationship with the commensal microflora such as that found in the gut ${ }^{39}$. The necessity for the mucosal immune system to strike a balance between tolerance and immunity encouraged the existence of compartmentspecific immunity. In fact, in mucosal epithelium there is differential expression of PRRs depending on basolateral and intracellular localization allowing for innate immune recognition of commensal bacteria yet confining innate immune activation ${ }^{39,40}$.

Along with mucosae, the first line of defense in humans is skin. Pathogen colonization in the skin is limited due to its low water content, acidic $\mathrm{pH}$, resident commensal microflora and surface-deposited antimicrobial lipids ${ }^{41}$. The production of mucins by epithelial cells however confines pathogenic colonization in the mucosae. Mucins are comprised of heavily glycosylated proteins forming a secreted gel-like sheet covering the epithelium. This mucus coating not only serves as a chemical barrier and epithelial lubricant, it also protects the mucosal lining from pathogen invasion as it contains a variety of host-derived molecules like immunoglobulin A (IgA) and anti-microbial peptides ${ }^{42,43}$. If pathogenic bacteria successfully manage to cross the mucus coating and invade the epithelium, neutrophils and macrophages are responsible for their phagocytic uptake and elimination as well as the secretion of proinflammatory cytokines such as IL- $1 \beta$ and IL- ${ }^{26}$. Not only do they activate the endothelium hence facilitate the recruitment of more phagocytes, upon entering the circulation these proinflammatory cytokines promote the secretion of acute phase proteins by hepatocytes in the liver. These acute phase proteins in their turn enhance phagocytosis (opsonizing) and activate the complement system ${ }^{44}$. The complement system helps to rapidly attract more macrophages and neutrophils (chemotaxis), to opsonize microbial infected cells for phagocytosis and to induce targeted cells lysis by rupturing the cell membrane of foreign cells ${ }^{44}$. Though these mechanisms seem apt at protecting us from pathogen invasion, innate immunity does not always prevail in effectively eliminating the invasion of countless pathogens in intricate multicellular organisms like humans. Therefore the immune system acquired of an extra level complexity; adaptive immunity.

\section{Continuous Interplay: InNATE ANd AdAPTIVE}

Lymphocytes (T-cells and B-cells) express antigen receptors that are incredibly specific and effective in recognizing and eliminating pathogens and infected/ or damaged cells. However, as conventional lymphocyte antigen receptors are assembled essentially at random, they are in essence incapable of pathogen recognizing and elimination. Therefore, they require instructions specifying the source and appearance of the antigen they need to recognize and eliminate. These instructions come from the innate immune system during phagocytosis. Phagocytosis is the consequence of the close interaction of several high affinity, low specificity phagocyticreceptors (PRRs, scavenger receptors, integrin's, complement receptors and Fc receptors) ${ }^{45}$, ${ }^{46}$ (Figure 1). As antigen presentation to intracellular NLRs and TLRs is occurring in the phagosome while the pathogen is being eliminated, antigens derived from the pathogen are also degraded and processed in order to be presented to the adaptive immune system through the major histocompatibility complex (MHC) ${ }^{47}$. Interestingly, the immunological effect of engagement of the phagocytic-receptors is not only dependent on the engaged ligand, it also 
depends greatly on the cellular context ${ }^{48}$, meaning the specific environmental conditions at that give time. This suggests that subtraction of the specific immunological meaning introduces a particular challenge for these high affinity, low specificity receptors and results in highly pliable immune responses ${ }^{49}$. However, it is not fully understood whether this immunological effect is determined by the receptor that is involved, by the cargo that is internalized or whether phagocytic-receptors affect signaling from other receptors involved during phagocytosis, such as TLRs ${ }^{47,50}$.

\section{The Adaptive Response: Cell Lysis and Antibody Response}

Presentation of antigens in MHC-complexes on the surface of antigen-presenting cells is how high affinity, high specificity lymphocyte-antigen receptors come into contact with the pathogens. In order to find each other, specialized lymphoid tissues have evolved as a central meeting point. Lymphocytes circulate through these lymphoid tissues, which drain most bodily tissues and organs, until they encounter the antigen presenting cell presenting an antigen for which they have a high affinity and high specificity ${ }^{51}$. This encounter will in both B- and T-lymphocytes initiate antibody responses and cell-mediated immune responses respectively. In antibody responses, antigen recognition by B-lymphocyte leads to activation, expansion and subsequent secretion of antibodies also known as immunoglobulins. The lavish of these antibodies circulate in the bloodstream and bind specifically to the antigen that initiated their production. Antibody-antigen binding not only inactivates viruses and microbial toxins by hindering their ability to bind to receptors on host cells, it also helps the innate immune system in recognizing invading pathogens for phagocytosis. In cell-mediated immune responses on the other hand, activated T-lymphocytes expand exponentially and interact directly with the specific pathogenic antigen that is presented on the surface of host cells in MHC complexes. Consequently, the T-lymphocytes eliminate the infected host cell thereby attempting to halt the spread of the intracellular pathogens. T-lymphocytes also produce lymphokines that enhance the killing of pathogens in the phagosomes ${ }^{52}$ (Figure 1). Most importantly, the human immune system can remember every antigen encountered by the development of memory B and/or T-cells. This unique feature of mammalian immunity promotes the immediate recognition and rapid yet specific response when encountering a particular antigen for the second time, without recurring debilitating disease ${ }^{1}$.

The minute immunity prevails, it needs to be resolved to prevent further collateral damage

53. Immune resolution is already initiated in the first hours after the onset of the immune response through both chemical mediators (lipoxins) as well as cellular programs (apoptosis and ingestion of neutrophils) ${ }^{54}$. It is only after complete termination of immunity that the damage can be inventoried and the tissue repaired in order to reestablish homeostasis.

\section{The Immune System and the Heart: Sterile versus Nonsterile}

Though pathogens are the most ancient threats to organisms and have therefore been the driving force behind the evolutionary development of the immune system, recognition and elimination of altered or damaged 'self' turned out to be just as vital for survival of multi-cellular organisms. Since the initial aim of the immune system is rather imprecise and unspecific, collateral damage is often faced. Whilst in pathogens-induced inflammation this imposed collateral damage is an acceptable price to pay, in situations where the provoking stimulus is non-pathogenic the cost-benefit ratio may be high ${ }^{55}$.

'Danger' or 'nonself' (for example pathogens, toxins, drugs or ischemia) can damage the heart at the expense of homeostasis hence demand for the pursuit of a new balance, led by 
the immune system. Where in infectious or non-sterile disease the elimination of the invader is evolutionary prioritized and needs to be addressed vigorously, sterile diseases require a more subtle approach. However, because in both diseases the organism relies on the shared high affinity, low specificity PRRs for recognizing the environmental changes, interpreting the underlying cause of damage, translating it into a well-tailored immune response seems challenging. However challenging, PRR recognition of PAMPs does result in added tailoring of the innate immune response towards viruses, bacteria or fungi. The consecutive production of type I interferons, in addition to the common cytokines and chemokines, is what distinguishes nonsterile from sterile immune activation as type I interferons modulate cell growth, establish an anti-viral state and influence the activation of various innate immune cells 56-59. Unfortunately, cardiotropic viruses have evolved a repertoire of tactics that allow them to antagonize interferons and thus evade the protective innate response of the host and replicate effectively in the cardiomyocytes ${ }^{60}$. Because cardiotropic viruses invading the myocardium induce cardiomyocytes death, DAMPs are also produced which amplify the immune response. Though it might seem compelling to think that attenuating inflammatory activity allows for increased viral replication, the opposite is the case. More inflammation supports virus-driven cellular signaling for successful replication ${ }^{61,62}$. Therefore, our increased understanding of the contribution of inflammation to cardiac injury during viral myocarditis implies that effective therapies should aim for selective intervention instead of broad immunosuppression ${ }^{63}$.

In sterile cardiac diseases like atherosclerosis or ischemia-induced cardiac injury, several endogenous TLR activators are involved in initiation and progression of the disease ${ }^{64}$. Here, sustained TLR activation by endogenous DAMPs, related to cell necrosis or matrix degradation, support inflammation and accompanying collateral damage. This continuing PRR activation in sterile diseases like cardiac ischemic injury or pressure overload is followed by the recruitment of numerous neutrophils from the circulation to the myocardium ${ }^{65}$. It has been shown that lack of neutrophils is devastating in infectious diseases due to the destructive spread of microbial particles ${ }^{66}$. However, while neutrophils are vital for fighting pathogens, in sterile diseases their value is negligible and even promotes collateral damage by protease secretion. Inhibiting the recruitment of neutrophils in sterile cardiac injury was shown to be favorable for proper wound healing after ischemia ${ }^{67,68}$. Therefore, hindering their presence in the heart may prohibit ongoing maladaptive changes leading to the development of HF ${ }^{69}$. In normal pathophysiology, the timely clearance of recruited neutrophils is the duty of macrophages and indispensable in promoting the shift towards tissue healing. Once more phagocytosis lays the groundwork seeing that macrophages that have ingested apoptotic cells increase their production of anti-inflammatory and pro-fibrotic cytokines, while decreasing the production of pro-inflammatory cytokines ${ }^{70,71}$. Certainly, hindrance of phagocytosis by macrophages promotes the continuing of inflammation in myocardial infarction ${ }^{72,73}$. The transition from inflammation to healing is believed to be the result of a shift in the macrophage phenotype from inflammatory ('M1') to healing ('M2'). However, whether macrophages can be classified as phenotypically fixed rather that a continuously changing and heterogeneous cell population needs still to be defined ${ }^{74}$. The identification of two immune phases in response to ischemic injury does imply the existence of distinct monocyte and macrophages phenotypes 75-77. Where pro-inflammatory immune cells are crucial in the first phase of cardiac repair, a timely shift towards an anti-inflammatory phase is critical for clearing inflammation and promoting subsequent healing ${ }^{78,79}$. So promoting the shift towards immune resolution presents an interesting new therapeutic avenue for suppressing HF development ${ }^{77}$. 


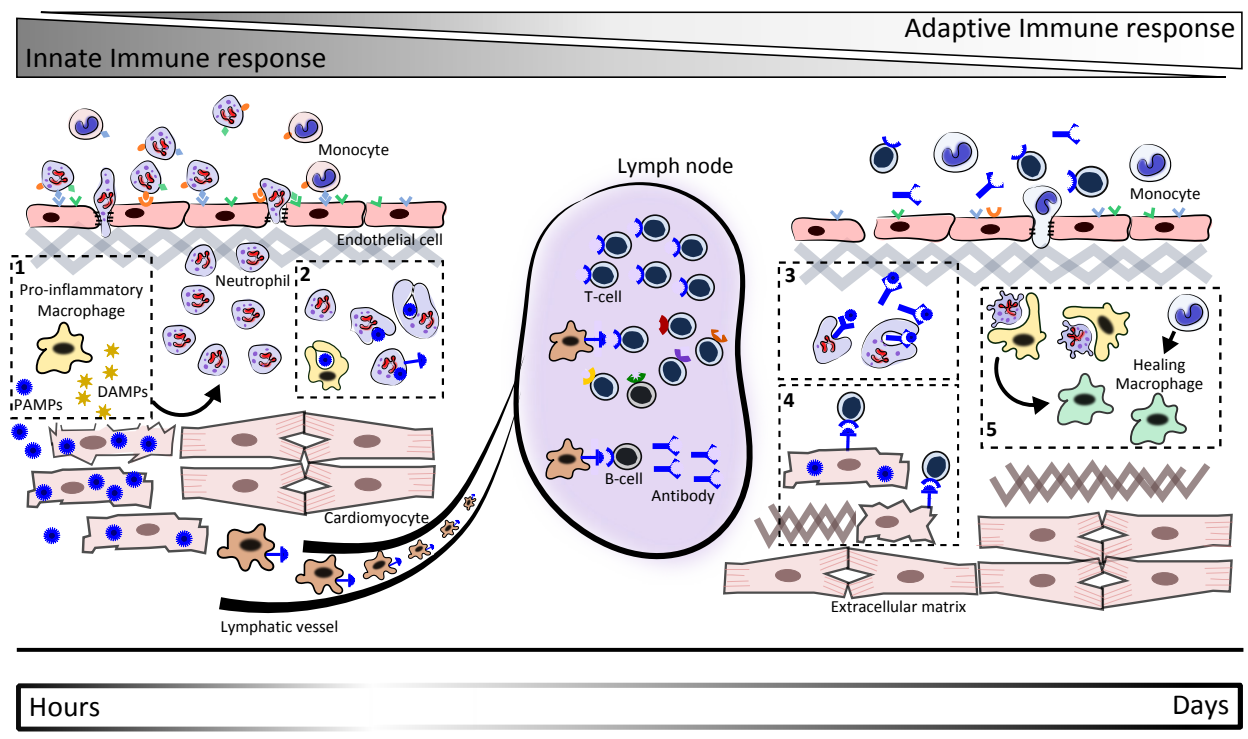

Figure 2 The immune system

The schematic overview illustrates the core modalities of the innate immune system. In response to cardiomyocyte injury or damage, eithers DAMPs or DAMPs and PAMPs are produced to alarm the immune system. Resident macrophages or dendritic cells containing Pattern Recognition Receptors (PRRs) recognize these molecular patterns and as a consequence start producing cytokines and chemokines (1.). These cytokines and chemokines activate the endothelium by increasing the expression of adhesion molecules. Recognition of adhesion molecules by circulating monocytes and neutrophils results in their recruitment to the site of injury (2.). The recruited monocytes transform into tissue macrophages which, together with neutrophil, clear all necrotic debris and pathogenic intruders by means of phagocytosis (3.). This vital step allows for antigen presentation which mobilizes the adaptive immune system. Phagocytosis is also a crucial initiator of immune resolution. Consequently, neutrophils become apoptotic, the phenotype of resident macrophages changes and a distinct monocyte subset is recruited. These healing macrophages clear the apoptotic neutrophils and promote the deposition of ECM components for proper scar formation (4.). Noteworthy, the innate immune responses and adaptive immune responses are tightly linked. A clear distinction between them on the basis of time is therefore extremely artificial.

PRR : Pathogen Recognition Receptor, DAMP : Danger Associated Molecular Pattern, PAMP : Pathogen Associated Molecular Pattern, ECM : extracellular matrix 
Finally, even without the presence of pathogenic invaders the involvement of adaptive immunity often follows, with varying outcomes ${ }^{80}$. As MHC class II molecules present degradation products originating from the lysosomal compartments, they present both 'nonself' and 'self'-antigens. Fusion of the phagosome with the lysosome is vital for effective pathogen clearance as the lysosome contains an array of enzymes capable of breaking down proteins, nucleic acids, carbohydrates and lipids. As these membrane enclosed organelles form the digestive system of the cell, they digest not only on material taken up via phagocytosis (pathogens) but also material taken up via endocytosis (extracellular material) or obsolete intracellular components (autophagy) ${ }^{81,82}$. Whereas in homeostasis the presentation of 'self' antigens is vital for ensuring immune tolerance at surface barriers (skin and mucosae) ${ }^{83}$, upon injury it might result in transient autoimmunity with subsequent collateral damage. Illustratively, lack of B- and T-lymphocytes reduced myocardial infarct size in mice after ischemic injury ${ }^{84}$. Unsupportively however, improved wound healing after ischemic injury was found in mice lacking MHC class II complexes suggesting a protective role for autoantigen presentation ${ }^{85}$.

\section{Conclusion}

Protecting organisms form both internal and external threats, is the sole mission of our ancient immune system. Assembling tools throughout its evolutionary life in order to keep up with rapid and constantly growing demands of evolving metazoans, was a requisite for fulfilling this mission. To date, our immune system is the most vigilant and vibrant organ closely collaborating with the endocrine and nervous system. Intimate relations with both the cellular and extracellular component are vital and provide indispensable information to the immune system. Misleading the immune system by pharmacologically rewiring this information coming from dying cells and extracellular components may form the key for curing life threatening human diseases like HF. In this, deciphering all endogenous immuneinformants and/ or regulators introduces an exhilarating challenge for fundamental research. 


\section{REFERENCES}

Janeway C. Immunobiology : The immune system in health and disease. New York: Garland Science; 2005.

2

Stamati K, Mudera V, Cheema U. Evolution of oxygen utilization in multicellular organisms and implications for cell signalling in tissue engineering. Journal of tissue engineering. 2011;2:2041731411432365

Danilova N. The evolution of immune mechanisms. Journal of experimental zoology. Part B, Molecular and developmental evolution. 2006;306:496-520 Hoffmann JA, Kafatos FC, Janeway CA, Ezekowitz RA. Phylogenetic perspectives in innate immunity. Science. 1999;284:1313-1318 (aneway CA, Jr, Medzhitov 2002;20:197-216 Han M, Qin S, Song X, Li Y, Jin P, Chen L, Ma F. Evolutionary rate patterns of genes involved in the drosophila toll and imd signaling pathway. BMC evolutionary biology. 2013;13:245 2006;24:497-518 , Rast JP, Shamblott MJ, Haire RN, Hulst M, Roess W, Litman RT, Hinds-Frey KR, Zilch A Amemiya CT. Phylogenetic diversification of immunoglobulin genes and the antibody repertoire. Molecular biology and evolution. 1993;10:60-72 Pancer Z, Amemiya CT, Ehrhardt GR, Ceitlin J, Gartland GL, Cooper MD. Somatic diversification of variable lymphocyte receptors in the agnathan sea lamprey. Nature. 2004;430:174-180 Alder MN, Rogozin IB, Iyer LM, Glazko GV, Cooper MD, Pancer Z. Diversity immune receptors in a jawless vertebrate. Science. 2005;310:1970-1973 topics in microbiology and immunology. 2000;248:67-107

Flajnik MF. Comparative analyses of immunoglobulin genes: Surprises and portents. Nature reviews. Immunology. 2002;2:688-698

Tauber Al. The immune self: Theory or metaphor? Immunology today. 1994;15:134-136

Silverstein AM. The clonal selection theory: What it really is and why modern challenges are misplaced. Nature immunology. 2002;3:793-796

Billingham RE, Brent L, Medawar PB. Actively acquired tolerance of foreign cells. Nature. 1953;172:603-606

Matzinger P. Tolerance, danger, and the extended family. Annual review of immunology. 1994;12:9911045

Vance RE. Cutting edge: Cutting edge commentary: A copernican revolution? Doubts about the danger theory. Journal of immunology. 2000;165:1725-1728

Raz E. Organ-specific regulation of innate immunity. Nature immunology. 2007;8:3-4

Smythies LE, Sellers M, Clements RH, Mosteller-Barnum M, Meng G, Benjamin WH, Orenstein JM, Smith PD. Human intestinal macrophages display profound inflammatory anergy despite avid phagocytic and bacteriocidal activity. J Clin Invest. 2005;115:66-75

Iwasaki A, Medzhitov R. Control of adaptive immunity by the innate immune system. Nature immunology. 2015;16:343-353

Cross AS. Endotoxin tolerance-current concepts in historical perspective. Journal of endotoxin research. 2002;8:83-98

Iwasaki A, Medzhitov R. Toll-like receptor control of the adaptive immune responses. Nature immunology. 2004;5:987-995

Figdor CG, van Kooyk Y, Adema GJ. C-type lectin receptors on dendritic cells and langerhans cells. Nature reviews. Immunology. 2002;2:77-84

Mitchell DA, Fadden AJ, Drickamer K. A novel mechanism of carbohydrate recognition by the c-type lectins dc-sign and dc-signr. Subunit organization and binding to multivalent ligands. The Journal of biological chemistry. 2001;276:28939-28945

Beckham SA, Brouwer J, Roth A, Wang D, Sadler AJ, John M, Jahn-Hofmann K, Williams BR, Wilce JA, Wilce MC. Conformational rearrangements of rig-i receptor on formation of a multiprotein:Dsrna assembly. Nucleic acids research. 2013;41:3436-3445

Mogensen TH. Pathogen recognition and inflammatory signaling in innate immune defenses. Clinical microbiology reviews. 2009;22:240-273, Table of Contents

Akira S, Uematsu S, Takeuchi O. Pathogen recognition and innate immunity. Cell. 2006;124:783-801 

that contributes to cpg-DNA-mediated receptor activation. Journal of immunology. 2009;182:76907697 Leulier F, Lemaitre B. Toll-like receptors--taking an evolutionary approach. Nature reviews. Genetics. 2008;9:165-178

$30 \mathrm{Ng} \mathrm{AC}$, Eisenberg JM, Heath RJ, Huett A, Robinson CM, Nau GJ, Xavier RJ. Human leucine-rich repeat proteins: A genome-wide bioinformatic categorization and functional analysis in innate immunity. Proceedings of the National Academy of Sciences of the United States of America. 2011;108 Suppl 1:4631-4638

31 Nagawa F, Kishishita N, Shimizu K, Hirose S, Miyoshi M, Nezu J, Nishimura T, Nishizumi H, Takahashi Y, Hashimoto S, Takeuchi M, Miyajima A, Takemori T, Otsuka AJ, Sakano H. Antigen-receptor genes of the agnathan lamprey are assembled by a process involving copy choice. Nature immunology. 2007;8:206-213

32 Kobe B, Deisenhofer J. Proteins with leucine-rich repeats. Current opinion in structural biology. 1995;5:409-416

33 Kobe B, Deisenhofer J. The leucine-rich repeat: A versatile binding motif. Trends in biochemical sciences. 1994;19:415-421

34 Matsushima N, Ohyanagi T, Tanaka T, Kretsinger RH. Super-motifs and evolution of tandem leucinerich repeats within the small proteoglycans--biglycan, decorin, lumican, fibromodulin, prelp, keratocan, osteoadherin, epiphycan, and osteoglycin. Proteins. 2000;38:210-225

35 Hugot JP, Chamaillard M, Zouali H, Lesage S, Cezard JP, Belaiche J, Almer S, Tysk C, O'Morain CA, Gassull M, Binder V, Finkel Y, Cortot A, Modigliani R, Laurent-Puig P, Gower-Rousseau C, Macry J, Colombel JF, Sahbatou M, Thomas G. Association of nod2 leucine-rich repeat variants with susceptibility to crohn's disease. Nature. 2001;411:599-603

36 Ogura Y, Bonen DK, Inohara N, Nicolae DL, Chen FF, Ramos R, Britton H, Moran T, Karaliuskas R, Duerr RH, Achkar JP, Brant SR, Bayless TM, Kirschner BS, Hanauer SB, Nunez G, Cho JH. A frameshift mutation in nod2 associated with susceptibility to crohn's disease. Nature. 2001;411:603-606

37 Swanberg M, Lidman O, Padyukov L, Eriksson P, Akesson E, Jagodic M, Lobell A, Khademi M, Borjesson $\mathrm{O}$, Lindgren $\mathrm{CM}$, Lundman $\mathrm{P}$, Brookes AJ, Kere J, Luthman $\mathrm{H}$, Alfredsson L, Hillert J, Klareskog L, Hamsten A, Piehl F, Olsson T. Mhc2ta is associated with differential mhc molecule expression and susceptibility to rheumatoid arthritis, multiple sclerosis and myocardial infarction. Nature genetics. 2005;37:486-494

38 Hawn TR, Verbon A, Lettinga KD, Zhao LP, Li SS, Laws RJ, Skerrett SJ, Beutler B, Schroeder L, Nachman A, Ozinsky A, Smith KD, Aderem A. A common dominant tlr5 stop codon polymorphism abolishes flagellin signaling and is associated with susceptibility to legionnaires' disease. The Journal of experimental medicine. 2003;198:1563-1572

39 Artis D. Epithelial-cell recognition of commensal bacteria and maintenance of immune homeostasis in the gut. Nature reviews. Immunology. 2008;8:411-420

40 Macpherson AJ, Harris NL. Interactions between commensal intestinal bacteria and the immune system. Nature reviews. Immunology. 2004;4:478-485

41 Elias PM. The skin barrier as an innate immune element. Seminars in immunopathology. 2007;29:314

42 Hasnain SZ, Gallagher AL, Grencis RK, Thornton DJ. A new role for mucins in immunity: Insights from gastrointestinal nematode infection. The international journal of biochemistry \& cell biology. 2013;45:364-374

43 Medzhitov R. Recognition of microorganisms and activation of the immune response. Nature. 2007;449:819-826

44 Dunkelberger JR, Song WC. Complement and its role in innate and adaptive immune responses. Cell research. 2010;20:34-50

45 Doyle SE, O'Connell RM, Miranda GA, Vaidya SA, Chow EK, Liu PT, Suzuki S, Suzuki N, Modlin RL, Yeh WC, Lane TF, Cheng G. Toll-like receptors induce a phagocytic gene program through p38. The Journal of experimental medicine. 2004;199:81-90

46 Aderem A, Underhill DM. Mechanisms of phagocytosis in macrophages. Annual review of immunology. 1999;17:593-623

47 Blander JM, Medzhitov R. On regulation of phagosome maturation and antigen presentation. Nature immunology. 2006; 7:1029-1035

48 Canton J, Neculai D, Grinstein S. Scavenger receptors in homeostasis and immunity. Nature reviews. Immunology. 2013;13:621-634

49 Stuart LM, Ezekowitz RA. Phagocytosis: Elegant complexity. Immunity. 2005;22:539-550 
50 Tricker E, Cheng G. With a little help from my friends: Modulation of phagocytosis through tlr activation. Cell research. 2008;18:711-712

51 Alberts B. Molecular biology of the cell. New York: Garland Science; 2002.

52 Tubo NJ, Jenkins MK. Cd4+t cells: Guardians of the phagosome. Clinical microbiology reviews. 2014;27:200-213

53 Goldszmid RS, Trinchieri G. The price of immunity. Nature immunology. 2012;13:932-938

54 Serhan CN, Savill J. Resolution of inflammation: The beginning programs the end. Nature immunology. 2005;6:1191-1197

55 Rock KL, Latz E, Ontiveros F, Kono H. The sterile inflammatory response. Annual review of immunology. 2010;28:321-342

56 Bowles NE, Vallejo J. Viral causes of cardiac inflammation. Current opinion in cardiology. 2003;18:182188

57 Fairweather D, Frisancho-Kiss S, Rose NR. Viruses as adjuvants for autoimmunity: Evidence from coxsackievirus-induced myocarditis. Reviews in medical virology. 2005;15:17-27

58 Triantafilou K, Orthopoulos G, Vakakis E, Ahmed MA, Golenbock DT, Lepper PM, Triantafilou M. Human cardiac inflammatory responses triggered by coxsackie $b$ viruses are mainly toll-like receptor (tIr) 8-dependent. Cellular microbiology. 2005;7:1117-1126 Yajima T, Knowlton KU. Viral myocarditis: From the perspective of the virus. Circulation. 2009;119:26152624

60 Versteeg GA, Garcia-Sastre A. Viral tricks to grid-lock the type i interferon system. Current opinion in microbiology. 2010;13:508-516

61 Marchant D, Si X, Luo H, McManus B, Yang D. The impact of cvb3 infection on host cell biology. Current topics in microbiology and immunology. 2008;323:177-198

62 Si X, Luo H, Morgan A, Zhang J, Wong J, Yuan J, Esfandiarei M, Gao G, Cheung C, McManus BM. Stress-activated protein kinases are involved in coxsackievirus b3 viral progeny release. Journal of virology. 2005;79:13875-13881

63 Corsten MF, Schroen B, Heymans S. Inflammation in viral myocarditis: Friend or foe? Trends in molecular medicine. 2012;18:426-437

64 Ionita MG, Arslan F, de Kleijn DP, Pasterkamp G. Endogenous inflammatory molecules engage toll-like receptors in cardiovascular disease. Journal of innate immunity. 2010;2:307-315 Kolaczkowska E, Kubes P. Neutrophil recruitment and function in health and inflammation. Nature reviews. Immunology. 2013;13:159-175

66 Dreyer WJ, Michael LH, Nguyen T, Smith CW, Anderson DC, Entman ML, Rossen RD. Kinetics of c5a release in cardiac lymph of dogs experiencing coronary artery ischemia-reperfusion injury. Circ Res. 1992;71:1518-1524 Romson JL, Hook BG, Kunkel SL, Abrams GD, Schork MA, Lucchesi BR. Reduction of the extent of ischemic myocardial injury by neutrophil depletion in the dog. Circulation. 1983;67:1016-1023 Jolly SR, Kane WJ, Hook BG, Abrams GD, Kunkel SL, Lucchesi BR. Reduction of myocardial infarct size by neutrophil depletion: Effect of duration of occlusion. American heart journal. 1986;112:682-690 Mann DL. The emerging role of innate immunity in the heart and vascular system: For whom the cell tolls. Circ Res. 2011;108:1133-1145

70 Fadok VA, McDonald PP, Bratton DL, Henson PM. Regulation of macrophage cytokine production by phagocytosis of apoptotic and post-apoptotic cells. Biochemical Society transactions. 1998;26:653656

71 Voll RE, Herrmann M, Roth EA, Stach C, Kalden JR, Girkontaite I. Immunosuppressive effects of apoptotic cells. Nature. 1997;390:350-351

72 Nahrendorf M, Swirski FK, Aikawa E, Stangenberg L, Wurdinger T, Figueiredo JL, Libby P, Weissleder $\mathrm{R}$, Pittet MJ. The healing myocardium sequentially mobilizes two monocyte subsets with divergent and complementary functions. J Exp Med. 2007;204:3037-3047

73 Wan E, Yeap XY, Dehn S, Terry R, Novak M, Zhang S, Iwata S, Han X, Homma S, Drosatos K, Lomasney J, Engman DM, Miller SD, Vaughan DE, Morrow JP, Kishore R, Thorp EB. Enhanced efferocytosis of apoptotic cardiomyocytes through myeloid-epithelial-reproductive tyrosine kinase links acute inflammation resolution to cardiac repair after infarction. Circ Res. 2013;113:1004-1012

74 Xue J, Schmidt SV, Sander J, Draffehn A, Krebs W, Quester I, De Nardo D, Gohel TD, Emde M, Schmidleithner L, Ganesan H, Nino-Castro A, Mallmann MR, Labzin L, Theis H, Kraut M, Beyer M, Latz E, Freeman TC, Ulas T, Schultze JL. Transcriptome-based network analysis reveals a spectrum model of human macrophage activation. Immunity. 2014;40:274-288

75 Nahrendorf M, Swirski FK. Regulating repair: Regulatory t cells in myocardial infarction. Circ Res. 2014;115:7-9 
76 Nahrendorf M, Pittet MJ, Swirski FK. Monocytes: Protagonists of infarct inflammation and repair after myocardial infarction. Circulation. 2010;121:2437-2445

77 Nahrendorf M. Macrophages in the infarct: Fiery friends or friendly fire? Journal of molecular and cellular cardiology. 2012;53:591-592

78 Courties G, Heidt T, Sebas M, Iwamoto Y, Jeon D, Truelove J, Tricot B, Wojtkiewicz G, Dutta P, Sager HB, Borodovsky A, Novobrantseva T, Klebanov B, Fitzgerald K, Anderson DG, Libby P, Swirski FK, Weissleder R, Nahrendorf $M$. In vivo silencing of the transcription factor irf5 reprograms the macrophage phenotype and improves infarct healing. Journal of the American College of Cardiology. 2014;63:1556-1566

79 Zhou LS, Zhao GL, Liu Q, Jiang SC, Wang Y, Zhang DM. Silencing collapsin response mediator protein-2 reprograms macrophage phenotype and improves infarct healing in experimental myocardial infarction model. Journal of inflammation. 2015;12:11

80 Epelman S, Liu PP, Mann DL. Role of innate and adaptive immune mechanisms in cardiac injury and repair. Nature reviews. Immunology. 2015;15:117-129

81 Cooper GM, Hausman RE. The cell : A molecular approach. Sunderland, MA: Sinauer Associates; 2013.

82 Munz C. Antigen processing for mhc class ii presentation via autophagy. Frontiers in immunology. 2012;3:9

83 Hopp AK, Rupp A, Lukacs-Kornek V. Self-antigen presentation by dendritic cells in autoimmunity. Frontiers in immunology. 2014;5:55

84 Yang Z, Day YJ, Toufektsian MC, Xu Y, Ramos SI, Marshall MA, French BA, Linden J. Myocardial infarctsparing effect of adenosine a2a receptor activation is due to its action on cd4+ $t$ lymphocytes. Circulation. 2006;114:2056-2064

85 Hofmann U, Beyersdorf N, Weirather J, Podolskaya A, Bauersachs J, Ertl G, Kerkau T, Frantz S. Activation of $\mathrm{cd} 4+\mathrm{t}$ lymphocytes improves wound healing and survival after experimental myocardial infarction in mice. Circulation. 2012;125:1652-1663 
$58 \times-2=$

T.

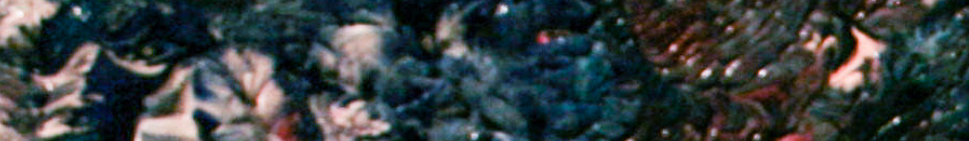

is 19

M. 3 - $13=$

$5 x^{2}-165=$

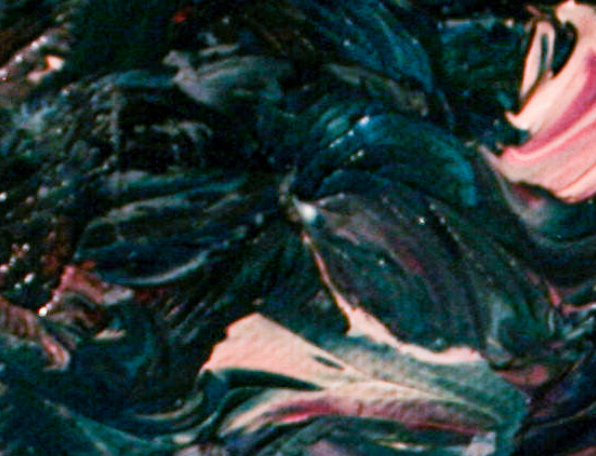

10

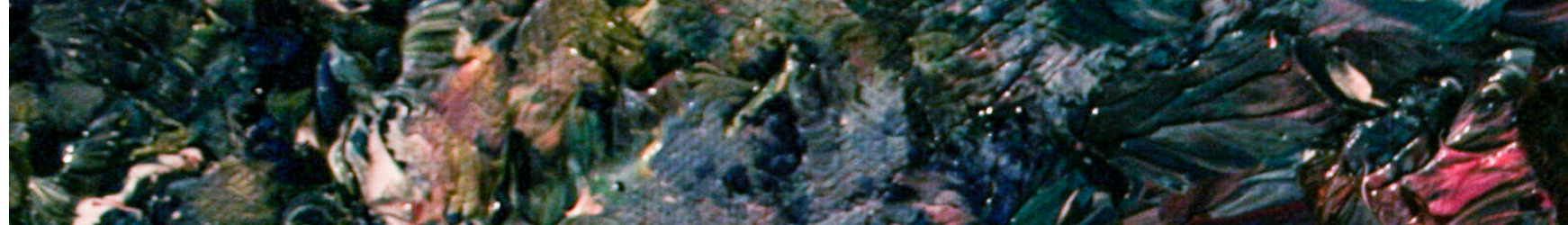

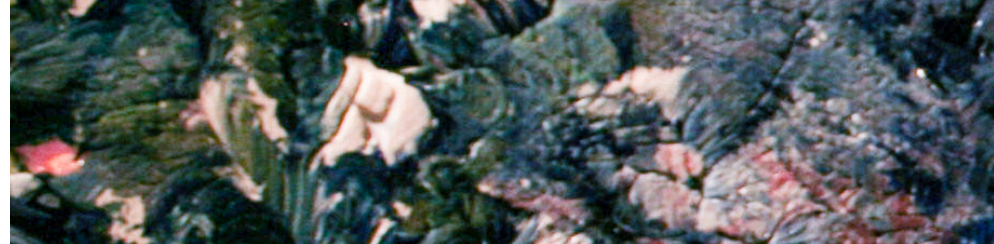
of

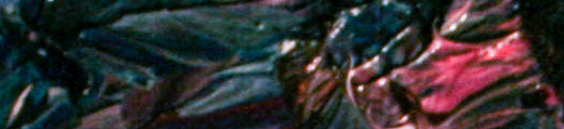

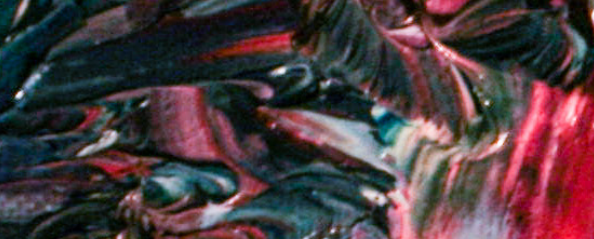

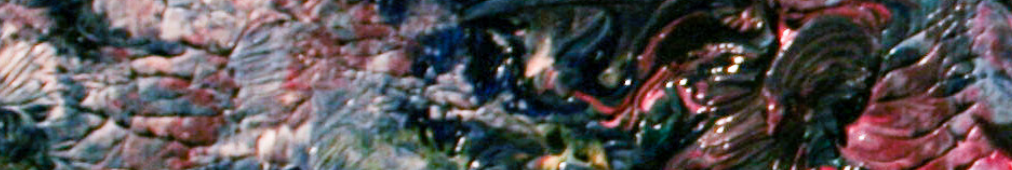
S1. - 4 .

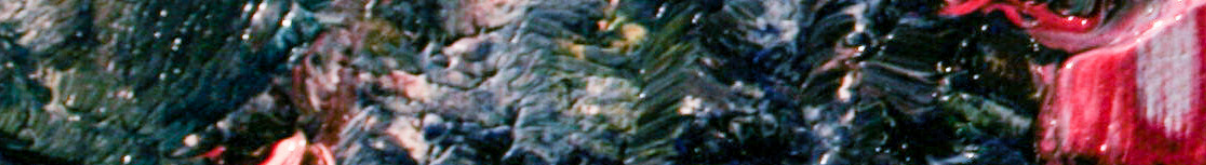
$\left(\frac{1}{2}\right)^{2}$ 


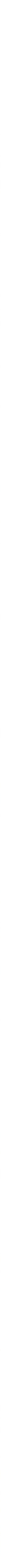




\section{Abstract}

Structural and non-structural proteins, creating strength and plasticity. The non-structural compartment of the ECM houses a variety of proteins which are vital for ECM plasticity, and can be divided into three major groups: glycoproteins, proteoglycans and glycosaminoglycans (GAGs). The common denominator for these groups is glycosylation, which refers to the decoration of proteins or lipids with sugars. This review will discuss the fundamental role of the matrix in cardiac development, homeostasis and remodeling, from a glycobiology point of view. Glycoproteins (e.g. thrombospondins, SPARC, tenascins), proteoglycans (e.g. versican, syndecans, biglycan) and GAGs (e.g. hyaluronan, heparan sulfate) are upregulated upon cardiac injury and regulate key processes in the remodeling myocardium like inflammation, fibrosis and angiogenesis. Albeit, some parallels can be made regarding the processes these proteins are involved in, their specific functions are extremely diverse. In fact, under varying conditions, individual proteins can even have opposing functions, making the spatiotemporal contribution of these proteins in the rearrangement of the multifaceted ECM very hard to grasp. Alterations of protein characteristics by the addition of sugars may explain the immense, yet tightly regulated, variability of the remodeling cardiac matrix. Understanding the role of glycosylation in altering the ultimate function of glycoproteins, proteoglycans and GAGs in the myocardium, may lead to the development of new biochemical structures or compounds with great therapeutic potential for patients with heart disease. 


\section{INTRODUCTION}

The cardiac extracellular matrix (ECM) is a complex meshwork of fibers comprised of matrix proteins in which cardiac myocytes, fibroblasts, leukocytes and cardiac vascular cells reside. Beside its structural role giving strength and support to the cardiac cells, the cardiac ECM also has important non-structural properties by accommodating multiple proteins with growth factor- and cell-receptor-binding properties. The present review will describe in detail the central involvement of the non-structural proteins in cardiac development and 'cardiac remodeling'. Our focus will mainly be on glycosylation, the decoration of proteins with added sugars that results in diversification of protein functionality, creating proteoglycans and glycoproteins, such as the well-known matricellular proteins ${ }^{1,2}$. To facilitate understanding of the functional diversity that added sugars contribute to the cardiac ECM, we will briefly describe some basic biochemical concepts regarding their biosynthesis and structure. Subsequently, we will discuss established functions, and will speculate on probable functions, of essential sugars and of the most important extracellular proteoglycans and glycoproteins (Figure 1).

\section{Cardiac Extracellular Matrix}

\begin{tabular}{|c|c|c|c|c|c|c|c|}
\hline \multicolumn{3}{|c|}{ GLYCOPROTEINS } & GAGS & \multicolumn{4}{|c|}{ PROTEOGLYCANS } \\
\hline $\begin{array}{l}\text { Prototypical } \\
\text { matricellular } \\
\text { proteins }\end{array}$ & Fibers & Others & Hyaluronan & Hyalectans & $\begin{array}{c}\text { Basement } \\
\text { Membrane } \\
\text { proteoglycans }\end{array}$ & $\begin{array}{l}\text { Cell Surface } \\
\text { proteoglycans }\end{array}$ & $\begin{array}{c}\text { Small Leucine } \\
\text { Rich Proteoglycans }\end{array}$ \\
\hline $\begin{array}{l}\text { Thrombospondin } \\
\text { SPARC } \\
\text { Tenascin } \\
\text { Osteopontin } \\
\text { Periostin } \\
\text { CCN }\end{array}$ & $\begin{array}{c}\text { Collagens } \\
\text { Elastins } \\
\text { (not glycosylated) }\end{array}$ & $\begin{array}{l}\text { Fibronectin } \\
\text { Laminin }\end{array}$ & & $\begin{array}{l}\text { Versican } \\
\text { Neurocan } \\
\text { Brevican } \\
\text { Aggrecan }\end{array}$ & $\begin{array}{c}\text { Perlecan } \\
\text { Collagen XVIII } \\
\text { Agrin }\end{array}$ & $\begin{array}{l}\text { Syndecan } \\
\text { Glypican }\end{array}$ & $\begin{array}{l}\text { Class I Biglycan, Decorin, Asporin } \\
\text { Class II Lumican, Fibromodulin, } \\
\text { PRELP, Keratocan, Osteoadherin } \\
\text { Class III Osteoglycin, Epiphycan, } \\
\begin{array}{c}\text { Optican } \\
\text { Class IV Chondroadherin, Nyctalopin, } \\
\text { Tsukushi }\end{array} \\
\text { Class V Podocan, Podocan-like protein } 1\end{array}$ \\
\hline
\end{tabular}

Figure 1 Classification of extracellular matrix (ECM) proteins.

The cardiac ECM is a complex meshwork of structural and non structural proteins and sugars that are further subdivided into glycoproteins, proteoglycans, and glycosaminoglycans. Some proteins serve a structural (blue) function in the ECM (eg, collagens), whereas others have nonstructural (pink) roles, such as matricellular proteins. In addition, there are glycoproteins such as fibronectin that are able to do both (purple). This reservoir of glycosylated proteins allows for flexibility and diversity in how cardiac ECM functions in health and disease. GAG indicates glycosaminoglycan; and SPARC, secreted protein acidic and rich in cysteine.

\section{Orchestrating the Ever-Changing Appearance of The Cardiac ECM}

Cardiac remodeling is the adaptive response of the cellular and extracellular compartments of the heart to mechanical or hormonal activation leading to changes in shape, volume and mass of the left ventricle ${ }^{3}$. Key initiators of this remodeling process are ischemia, pressure overload, ageing and viral infection ${ }^{4}$. Non-structural proteins are important modulators of ECM rearrangement in response to cardiac injury, demonstrated by their increased expression upon cardiac injury ${ }^{5}$. The numerous functions of these proteins are generally ascribed to their different structural protein domains, yet 'when' and 'why' these protein domains have such 
diverse and sometimes even opposing functions, is rarely addressed. Part of the explanation lies in proteolytic processing of non-structural proteins by MMPs, which can release previously masked epitopes increasing functionality ${ }^{6}$. This well accepted concept however doesn't explain 'why', under pathophysiological conditions, these core protein domains are released at very specific times by very ubiquitously expressed enzymes. Glycosylation on the other hand, may expand the functional plasticity of these proteins by influencing protein folding, through protection from degradation or even by altering epitope recognition. Moreover, some sugars even have independent functionalities hence are accountable for many important biological protein functions. We believe our attention must shift towards the prominent biological process of glycosylation, which increases the functional range of the ECM and allows for a more complete explanation of spatiotemporal, functional variability of core protein domains. For the purpose of this review, we would like to place glycobiology at the heart of our reassessment of the cardiac ECM.

\section{Glycosylation: What is IT and Why is it Important?}

Glycosylation, the addition of sugars prior to protein secretion, is one of the most prominent and complex forms of post-translational modification in biology ${ }^{7,8}$. More than $50 \%$ of the proteins in vertebrates are predicted to be glycosylated, allowing for enormous diversity in both structure and function ${ }^{9}$. Sugars were first demonstrated in eukaryotes in 1930 and about 40 years later in bacteria and archaea ${ }^{10}$. However, they are also present in 'living fossils' (cyanobacteria isolated from marine stromatolites), suggesting that eukaryotes may have inherited this glycosylation machinery from bacteria ${ }^{8,11}$. Accordingly, sugars are one of the four basic components of eukaryotic cells, and are present intracellular, extracellular or on the surface ${ }^{10}$. They modulate various biological processes like cell adhesion, signal transduction, immunity, embryonic development and microbial recognition, to name a few ${ }^{12}$, 13. The most common forms of glycosylation in mammalian cells are $\mathrm{N}$-linked and O-linked, and can modify both intracellular and extracellular proteins and lipids. N-linked and O-linked glycosylation of nascent proteins takes place in the Endoplasmic Reticulum (ER) as well as the Golgi Apparatus, and entails many different enzymes ${ }^{14}{ }^{15}$. The difference between N-linked and O-linked glycosylation lies in which amino acid they bind to, either the amide nitrogen 'N-H' of an Asparagine residue (N- linked) or hydroxyl '-OH' group of Serine or Threonine residues (O-linked). Via either $\mathrm{N}$-linked or O-linked glycosylation, different sugar chains like glycans and glycosaminoglycans (GAGs) are bound to proteins. Branched oligosaccharides (glycans) alter protein function by influencing protein folding, stability, activity, distribution, targeting and recognition ${ }^{16,17}$ by forming glycoproteins. Unbranched linear polysaccharides consisting of repeating disaccharide units (GAGs) add biological function to proteins 7,16 , ${ }^{17}$ by forming proteoglycans (Figure 2). Recapitulating, glycans are biologically active sugars that don't have independent functions but merely alter original protein function, creating glycoproteins. GAGs are biologically active sugars with independent functions that can be found on their own or bound to a core protein in the cardiac ECM, creating proteoglycans. GAGs thereby can both influence and enrich protein functionality. However, their biological function is not dependent on their attachment to a protein. 


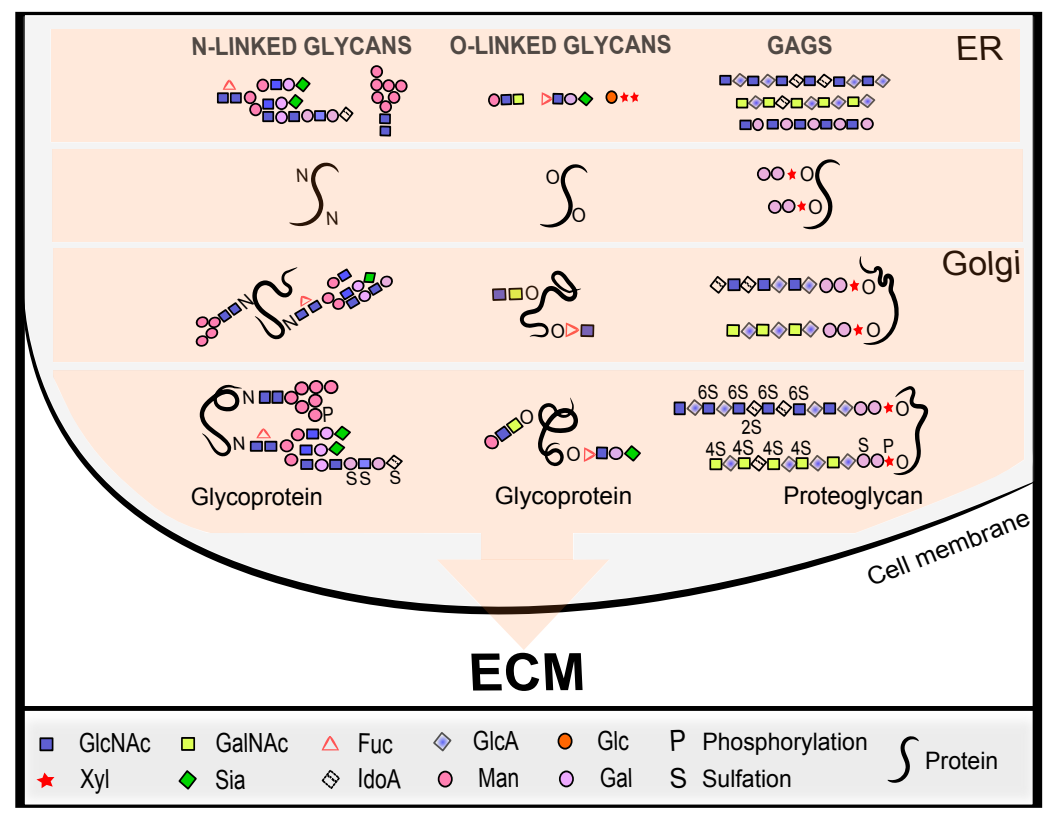

Figure 2 Glycosylation.

Glycolsylation of matrix proteins is a post-translational modification taking place in the endoplasmatic reticulum (ER) and the Golgi apparatus of mammalian cells. Glycosylation is the addition of either glycans or glycosaminoglycans (GAGs) to the protein backbone. Glycans are bound via O-linked and N-linked glycosylation, whereas GAGs are mostly bound via O-linked glycosylation. Multiple enzymes enable the addition of these chains to the protein and are responsible for chain elongation and modification, such as sulfation $(\mathrm{S})$ and phosphorylation $(\mathrm{P})$, resulting in the formation of proteoglycans and glycoproteins. Depending on protein characteristics and enzymatic availability, any sugar chains can potentially be bound to any protein backbone, forming diverse proteoglycan or glycoprotein structures, as found in the extracellular matrix (ECM). Fuc indicates fucose; Gal, galactose; GalNAc, N-acetylgalactosamine; Glc, glucose; GlcA, glucuronic acid; GlcNAc, N-acetylglucosamine; IdoA, iduronic acid; Man, mannose; Sia, sialic acid; and Xyl, xylose.

\section{GAGs: Great Potential for Sugars in Cardiac Matrix Biology}

GAGs are among the most negatively charged molecules in mammalian tissues, allowing reversible and irreversible interaction with other matrix proteins, growth factors and growth factor receptors in the ECM that bear positive charges on their surface. Their varied intracellular production and seemingly random attachment to proteins, allows for wide-ranging protein functionality by altering or adding specific protein functions/characteristics. Before we consider the broad range of functions of the most important bound GAGs in the cardiac ECM, we will attempt to introduce some key biochemical concepts to facilitate understanding of their functional variability.

GaGs and Proteoglycans: Biosynthesis of Variable Polysaccharide Structures The broad range in functions of the different GAGs can be attributed to their distinct 
assembly of sugars. Based on their core disaccharide structure, GAGs are subdivided into four major groups: chondroitin-(CS)/ dermatan sulfate (DS), heparin, heparan sulfate (HS), keratan sulfate $(\mathrm{KS})$ and hyaluronan, also known as hyaluronic acid. All GAGs are produced in the ER and Golgi apparatus except for hyaluronan, which is not generated in the Golgi but formed at the plasma membrane. It therefore is not attached to a core protein and also not sulfated in contrast to the other GAGs ${ }^{18,19}$. In order to fully understand the importance of variation in GAG structures for GAG and proteoglycan function, we will briefly discuss O-linked GAG synthesis, exemplifying variability for all $\mathrm{N}$-linked and O-linked GAGs and glycans. For more detailed information regarding $\mathrm{N}$-linked or O-linked glycosylation we would like to refer to specialized biochemical reviews ${ }^{7,8}$.

Translated proteins entering the ER are first modified by xylosyltransferases, adding xylose (Xyl) to a serine or threonine residue. Subsequently, in the Golgi apparatus different enzymes are responsible for adding two galactose $(\mathrm{Gal})$ residues and a glucuronic acid (GlcA), which completes the tetrasaccharide linker unit (Figure 2). Addition of the fifth monosaccharide determines whether the sugar chain will become heparin/ HS or CS/ DS. Several enzymes like EXT1 and EXT2 (glucuronyl/N-acetylglucosaminyl transferases) further elongate the heparin/ HS chain by adding repeating disaccharide units after which epimerase converts GlcA to Iduronic acid (IdoA). Epimerization is an important step in the formation of these GAG structures, since IdoA can change important functional characteristic of the sugar chain. Elongation of the CS/ DS chain on the other hand, is being coordinated by 6 different chondroitin glycotransferases. Further, epimerization of GlcA to IdoA is required to form DS, although this is not a requisite for the formation of CS. Lastly, chains are modified by multiple $\mathrm{N}$-, O-sulfotransferases and $\mathrm{N}$-deacetylase ${ }^{20}$, which can further influence ultimate functional properties. The importance of all these specific enzymes in overall protein function is supported by the broad clinical manifestation of inherited glycosylation disorders in humans, such as carbohydrate-deficient glycoprotein syndromes and congenital disorders of glycosylation $(\mathrm{CDG})^{21}$.

\section{GaGs and Proteoglycans: Customizing Sugars and Sugar-Protein Structures to Meet EnVironmental NeEds?}

The functional plasticity of GAG and proteoglycan structures is illustrated by the nontemplate driven synthesis in the Golgi apparatus, which we described briefly in the previous section. Hence, what decides whether a sugar chain will become HS or DS and to what extent the chain is modified? Up to now, studies have mainly focused on investigating the role of total protein content in cardiac disease; as a result, the effect of proteoglycan/GAG composition and proteolytic processing on protein function is not often addressed. However, several important concepts have been established regarding GAG chain extension and modification. Besides important protein characteristics ${ }^{22}$, the spatiotemporal distribution of the enzymes in the ER and Golgi apparatus can influence the eventual 'GAG-protein' structure produced by the cell 23, 24. In spite of extensive research, the sequential and mutual role of these sixteen currently identified and differentially expressed enzymes, together with their co-localization in the Golgi apparatus, hasn't been completely clarified. Nevertheless, the significance of enzymatic chain modifications (sulfation) for ultimate functional characteristics of the GAG chain is well established, as illustrated by HS in HS proteoglycans syndecan and perlecan. HS is required for bFGF-receptor binding and activity, in both these HS proteoglycans ${ }^{25}$. Affinity purified testing of several HS proteoglycan species however, demonstrates high affinity of perlecan in 
promoting and activating bFGF-receptor binding, whereas the affinity of syndecan- 4 appears to be very low ${ }^{26}$. As it appears, bFGF binding by HS is dependent on differential structural requirements of the HS chain, like the sulfation pattern, creating functional variability ${ }^{25}$. Still, whether there is a pre-determined fixed GAG-sequence remains elusive ${ }^{27-29}$. Yet, this vibrant glycosylation machinery in the Golgi enables production of unfixed GAG or glycan structures, leading to unfixed proteoglycan or glycoprotein structures, thereby significantly increasing biological variability of these proteins adjustable to environmental needs.

Besides increasing functional variability by creating unfixed proteoglycan or glycoprotein structures, spatiotemporal proteolytic processing further increases the functional range of these single proteins. The significance of proteolytic processing in protein functionality is suggested by the membrane bound HS proteoglycan syndecan-4. In the remodeling heart, full-length membrane-bound syndecan- 4 and its shed extracellular ectodomain have very distinct effects 30. Enzymatic shedding or degradation of syndecan- 4 alters its structural conformation and thereby its function. This emphasizes again protein plasticity by tailoring GAG/proteoglycan production and proteolytic processing in response to environmental needs.

\section{Gags and Proteoglycans: Clinical Relevance of Studying Customized Sugars or Sugar-Protein STructures}

The clinical relevance of glycosylation was first recognized in the early 1930 by the discovery of blood groups, for which different sugars are responsible ${ }^{31}$. Furthermore, heparin is one of the most commonly used anti-thrombotic drugs worldwide ${ }^{32}$. The importance of GAGs and proteoglycans for clinical practice is illustrated by the recall of heparin in 2008. In late 2007 and early 2008, administration of anticoagulant heparin in hemodialysis patients caused serious adverse effects, including hypotension, swelling of the larynx and angioedema and in some cases even death ${ }^{33}$. Oversulfated CS was later identified as a contaminant, explaining the anaphylactic response ${ }^{33}$. Further examination of the heparin samples demonstrated the presence of $\mathrm{N}$-acetyl glucosamine residues in a small heparin fraction ${ }^{34}$. Previous analysis already showed that substitution of the amino group of the glucosamine residue with an acetyl group can subsequently change the function of heparin, confirmed by the clear non-anticoagulant properties of $\mathrm{N}$-acetyl heparin ${ }^{35,36}$. In fact, the substitute groups on the glucosamine residue determine its anticoagulant activity and in vivo deposition ${ }^{35}$, which illustrates the importance of the understanding GAG biosynthesis and chain structure for clinical use.

\section{GaGs in the Heart: Challenging Candidates for Future Research}

\section{HYALURONAN AND HEPARIN}

Hyaluronan is the largest GAG in the cardiac ECM, and is the only one not attached to a core protein. It is known to form non-covalently linked complexes with proteoglycans. It was the first GAG to be discovered in 1934 by Karl Meyer and John W. Palmer ${ }^{37}$ and therefore the most comprehensively described in the heart ${ }^{38-50}$. Expression of hyaluronan is upregulated in experimental models of myocardial infarction ${ }^{50}$, myocarditis ${ }^{51}$ and cardiac hypertrophy ${ }^{43,49}$.

In 1985, West et al demonstrated, that oligosaccharides derived from high molecular weight hyaluronan can have very distinct functions compared with the large hyaluronan variants ${ }^{52}$. In the intact ECM, hyaluronan exists mainly as a high molecular weight polysaccharide, whereas upon injury, low molecular weight fragments are generated ${ }^{53}$. These hyaluronan fragments induce pro-inflammatory signaling in endothelial cells and leukocytes; their clearance through 
a CD44-dependent mechanism is a major step in resolution of the inflammatory response 54 . Moreover, hyaluronan/CD44 signaling plays an important role in promoting wound healing.55 Hyaluronan is essential for TGF-beta induced myofibroblast differentiation ${ }^{56-60}$. CD44 null fibroblasts exhibit impaired responses to TGF-beta ${ }^{54}$, highlighting the potential involvement of hyaluronan/CD44 signaling in cardiac repair. Lastly, an in vitro study suggests protective effects of hyaluronan on peroxide-treated cardiomyocytes ${ }^{40}$.

Implications in cardiac remodeling have also been demonstrated for heparin, a GAG secreted by mast cells. Beneficial effects of $\mathrm{N}$-acetyl heparin administration have been demonstrated in rodent myocardial infarction as suggested by preserved cardiac function and reduced infarct size ${ }^{61-65}$.

\section{Heparan Sulfate, CHONDRoitin Sulfate AND DERMATAN Sulfate}

Published evidence suggests that HS, CS and DS are important in cardiac development and in the pathogenesis of valvular heart disease ${ }^{66-74}$. Also, GAGs are important in cardiac remodeling ${ }^{75}$, more specifically in cardiac hypertrophy ${ }^{76}$, age-related degeneration of the myocardium ${ }^{77}$, ${ }^{78}$ and myocardial infarction ${ }^{79,80}$. Their importance is suggested by the increased expression of xylotransferase I, the enzyme responsible for attaching the GAG tertrasaccharide linker unit, and CS in patients with dilated cardiomyopathy ${ }^{75}$. This upregulation is also seen in fibroblasts stimulated with TGF-beta or subjected to mechanical stress ${ }^{75}$. Some experimental studies support a potential role for GAGs in cardiac remodeling following myocardial infarction, demonstrated by the increase of CS and DS expression in the myocardial scars of dogs and rats ${ }^{80,81}$. In fact, rats receiving gene transfer therapy with VEGF immediately after myocardial infarction, show increased presence of CS and HS, and a clear downregulation of heparanase (a HS degrading enzyme) ${ }^{79}$, which has been associated with improved cardiomyocyte survival and enhanced revascularization, recovery and function ${ }^{82}$. The significance of GAGs in tissue organization and repair is further supported by the association of tissue degeneration with decreased GAG content in porcine aortic valves ${ }^{78}$. Remarkably, in the aged rat myocardium, alterations occur in the sulfation pattern of the HS side chains leading to structural and functional changes, such as the altered capacity of potentiating growth factor function ${ }^{77}$. Most importantly, heparin and HS can inhibit angiotensin II-induced hypertrophy in rat neonatal cardiomyocyte, indicating great therapeutic potential for these GAGs in hypertrophic cardiomyopathies ${ }^{83}$.

\section{Proteoglycans in the Heart}

Matrix proteoglycans are divided into subgroups according to their extracellular localization, size and their structural properties (figure 1); they include the hyalectans (versican, aggrecan, neurocan and brevican), the basement membrane proteoglycans (perlecan, collagen type XVIII and agrin), cell surface proteoglycans, (syndecans and glypicans) and small leucine rich proteoglycans (such as biglycan, decorin, lumican and osteoglycin) ${ }^{84}$. Although studies into the role of matrix proteoglycans in the heart are limited, we will focus on the proteoglycans that have been implicated in cardiac pathology and will briefly discuss their effects in other systems that may be relevant to cardiac pathophysiologic conditions (see Table 1).

\section{Cell Surface Proteoglycans: Syndecans}

Syndecans are a family of four transmembrane receptors consisting of a conserved extracellular ectodomain, a transmembrane domain and a very short cytoplasmic domain ${ }^{85}$. 
The extracellular ectodomain is unique for every syndecan, yet it contains conserved GAG attachment sites, of which HS is the most prevalent ${ }^{86}$. The extracellular domain of syndecan, with its HS/CS side chains, can modulate interactions with other matrix proteins, growth factors or growth factor receptors.

Transcript levels of all four syndecan members increase in the myocardium of mice and rats upon injury ${ }^{85,87-89}$. Increased syndecan-1 and -4 expression is of great significance in infarct healing ${ }^{90}$, protecting against cardiac dysfunction and dilatation ${ }^{30,91}$. Indeed, loss-of-function studies show an important role for syndecan-1 in proper infarct healing. Fourteen days after myocardial infarction, mice lacking syndecan-1 demonstrate increased leukocyte recruitment and impaired formation of collagen fibers in the infarct area ${ }^{91}$. In fact, overexpressing syndecan-1 further protects against cardiac dysfunction and dilatation by reducing inflammation and by improving collagen quality in the infarct ${ }^{91}$; these findings may suggest therapeutic potential. However, the effects of syndecan-1 in experimental models of cardiac remodeling are not always protective, reflecting the diverse functions of the molecule. Increased syndecan-1 expression during angiotensin II-induced pressure overload, increases cardiac fibrosis by increasing CCN2 and collagen expression, thereby inducing cardiac dysfunction ${ }^{92,93}$.

Evidence from loss-of-function studies suggest that syndecan- 4 also plays an important role in cardiac remodeling following myocardial infarction. Syndecan-4 null mice demonstrate increased cardiac rupture and worse cardiac function after myocardial infarction by impaired granulation tissue formation ${ }^{30}$. Lack of syndecan- 4 also impairs fibroblast function and bFGF induced endothelial cell proliferation and tube formation ${ }^{30}$. Overexpressing syndecan- 4 with an adenoviral (Ad) vector in a rat myocardial infarction model further supports the protective role of this proteoglycan, possibly mediated by inducing angiogenesis, and by inhibiting inflammation and fibrosis ${ }^{94}$. On the other hand, overexpression of the syndecan-4 ectodomain appears to be deleterious. As mentioned previously, overexpressing the extracellular domain of syndecan- 4 impairs cardiac function and increases cardiac rupture after myocardial infarction by impairing granulation tissue formation ${ }^{30}$. This syndecan- 4 ectodomain produced by the adenoviral overexpressing vector, similar to syndecan- 4 produced by enzymatic shedding, acts as a dominant-negative inhibitor of endogenous syndecan- $4{ }^{30}$. While lack of syndecan- 4 is associated with impaired wound healing after myocardial infarction mainly by influencing fibroblast/leukocyte recruitment and function, a cardiomyocyte-specific function may affect the outcome simultaneously. In a model of ischemia-reperfusion injury, syndecan- 4 null mice exhibited increased myocardial damage due to enhanced cardiomyocyte apoptosis ${ }^{95}$. Hence lack of syndecan- 4 is associated with increased infarct size. However, 7 days after ischemia-reperfusion syndecan- 4 loss is also associated with increased cardiomyocyte area and enhanced nuclear factor of activated T-cell (NFAT) activity in the border infarct and remote left ventricle, with accompanying improved cardiac function ${ }^{95}$. In fact, by inhibiting NFAT signaling syndecan-4 null mice develop left ventricular dilatation and dysfunction in response to aortic banding, instead of concentric hypertrophy as found in the wild type animals ${ }^{96}$. The effects of syndecan- 4 on both cardiomyocytes and fibroblasts/leukocytes demonstrate different functions during different stages of the disease. This might be a consequence of differential glycosylation patterns demonstrating its flexibility as a cell surface proteoglycan, however further research is needed to confirm this hypothesis.

\section{Hyalectans: Versican}

The dynamic ECM comprises various multifunctional proteins which confer not only structural integrity but also the bioavailability of growth factors and cytokines to the 
surrounding tissue. Hyalectans, a group of proteoglycans named after their lectin-binding properties and their ability to bind hyaluronan ${ }^{97}$, are amongst these multifunctional ECM proteins. The size of the core protein of these proteoglycans varies between $50-400 \mathrm{kDa}$ and contains around 100-150 GAGs. Hence, glycosylation further increases their molecular weight, as a result of which they are found in the ECM with sizes ranging from 1000 to 2500 $\mathrm{kDa}{ }^{98-100}$. Further alternative splicing of the versican gene which encodes the GAG chain binding sites generates at least 4 isoforms with different molecular weights, creating even more variation. These large matrix components interact with other matrix proteins, growth factor and cell surface receptors.

Versican is ubiquitously expressed throughout the body and was first appreciated in the joints and cartilage for its hygroscopic properties. Attracting or holding water in the ECM is very important for enabling cell motility during development and disease. Studies regarding the functions of versican in the heart show that it is a much-needed component in the cardiac ECM during cardiac development ${ }^{66,67,101,102}$ and may be involved in the pathogenesis of valvular disease ${ }^{102-104}$. Unfortunately, not much is known regarding specific functions of versican in conditions associated with cardiac remodeling, such as myocardial infarction, angiotensin-induced cardiac hypertrophy, ageing or myocarditis. However, versican may exert important actions on the remodeling heart by modulating cytokine and growth factor responses and through interactions with other components of the extracellular matrix. Versican can bind many matrix components and inflammatory mediators, including hyaluronan, type I collagen, tenascin-R, fibulin-1 and -2, fibrillin-1, fibronectin and chemokines ${ }^{105}$. Moreover, versican binds several cell surface receptors such as CD44, beta1 integrin epidermal growth factor receptor (EGFR), L and P-selectin ${ }^{106}$, low density lipoprotein (LDL), glycoprotein ligand- ${ }^{105,107}$ and TLR $2{ }^{108}$, and may modulate a wide range of cellular responses, such as cell proliferation, motility and inflammatory activation. In vitro studies have suggested important actions of versican in modulating inflammatory responses; these actions could be important in a wide range of cardiac pathophysiologic conditions including myocardial infarction and myocarditis. For instance, versican binding to hyaluronan may promote leukocyte adhesion to the ECM ${ }^{106,109,110}$ which may trigger CD44 signaling ${ }^{106}$. Also, versican-mediated stimulation of TLRs following injury elicits pro-inflammatory cytokine production and therefore enhances leukocyte attraction ${ }^{111}$. Recruited leukocytes comprising monocytes show a clear induction of versican expression, which is further induced upon differentiation towards macrophages ${ }^{112}$. In the heart, versican induction is also observed in monocytes that infiltrate the myocardial infarct ${ }^{113}$. It has even been proposed that versican is related to macrophage polarization, a key cellular event in myocardial inflammation and repair, suggested by decreased versican gene expression in M2 versus M1 human macrophages ${ }^{114}$.

\section{Basement Membrane Proteoglycans: Perlecan}

Perlecan is a large basement membrane proteoglycan most predominantly found in the vascular ECM. It contains both pro- and anti-angiogenic properties, which are partly mediated through the binding capacities of its HS with FGF2 ${ }^{115,116}$. The specific role of perlecan and its HS side chains in angiogenesis remains to be elucidated. It has been speculated that varied biochemical GAG and protein-GAG structures together with their proteolytic processing may be responsible for the broad and seemingly inconsistent functional range of perlecan. Our knowledge on the role of perlecan in the myocardium is limited to studies demonstrating its crucial role in cardiac development ${ }^{117-119}$. Whether perlecan is involved in regulation of angiogenesis following myocardial ischemia and/or infarction, remains unknown. 


\section{Small Leucine Rich Proteoglycans}

Small leucine rich proteoglycans (SLRPs) represent a group of extracellular proteins with similar low molecular weight $(36-42 \mathrm{kDa})$ and structural organization comprising leucine rich repeats flanked by cysteine residues. The SLRPs are divided into 5 different protein classes (figure 1) based on their unique composition of tandem leucine rich repeats (LRRs) ${ }^{120}$. Each SLRP can be differentially glycosylated by the attachment of various types of glycans and GAGs. After original identification of these proteoglycans in the bone and cartilage ${ }^{121}$, their involvement has expanded to cancer biology, immunity and embryonic development ${ }^{122-124}$. As a result of their diverse protein cores and GAG side chains, SLRPs interact with various cytokines, growth factors, cell surface receptors as well as other matrix proteins. Indeed they can bind different types of collagens ${ }^{125}$, TLRs ${ }^{123}$, epidermal growth factor receptor (EGFR) and insulin growth factor receptor (IGFR) ${ }^{126}$, LDL receptor ${ }^{127}$ and TGF-beta ${ }^{128}$. These interactions illustrate the involvement of SLRPs in a wide range of cellular functions and pathophysiologic responses, including collagen fibril assembly ${ }^{125}$, inflammation ${ }^{123}$, cell proliferation ${ }^{126}$, atherosclerosis ${ }^{127}$ and fibrosis ${ }^{128}$, hence emphasizing their potential role in cardiac matrix biology.

The expression pattern of SLRPs supports their possible involvement in cardiac homeostasis and remodeling. Indeed, SLRPs decorin, biglycan and lumican are ubiquitously expressed in mitral valves ${ }^{70,129}$. Following mitral regurgitation, decorin expression increases in the mitral valve leaflets ${ }^{130}$ whereas in the left ventricle decorin and lumican expression decreases ${ }^{131}$. Remodeling of the left ventricle in response to mechanical or hormonal activation leads to changes in the expression of matrix components, like these SLRPs. In patients with aortic stenosis, expression of the SLRP osteoglycin is markedly increased and shows a strong correlation with left ventricular mass illustrating the association between SLRPs and cardiac remodeling ${ }^{132}$. Although all members of the SLRPs are important regulatory ECM components ${ }^{132,}{ }^{133}$, we will only focus on the main members that have been implicated in myocardial pathology. However, published evidence on the specific functions of SLRPs in cardiac remodeling is limited.

\section{CLASS I SLRPS: NIGLYCAN AND DECORIN}

Biglycan and Decorin are members of Class I SLRPs and contain either CS or DS sidechains, which are often highly sulfated. These SLRPs modulate ECM organization, cellular adhesion and migration ${ }^{133}$. Their expression is ubiquitous in the normal heart ${ }^{134-136}$, and increases in response to pressure overload ${ }^{137-139}$ and myocardial infarction ${ }^{140-142}$. Biglycan appears crucial in infarct healing by ensuring proper collagen scar formation through stimulating collagen fibril assembly and thereby prevents infarct dilatation and overall dysfunction ${ }^{143}$, 144. Transgenic mice overexpressing human biglycan upregulate the expression of proteins like TGF-beta and the NOS family, suggesting a potential role for biglycan in cardiac remodeling and cardioprotection ${ }^{145}$. In vitro studies suggest a cytoprotective effect for biglycan in neonatal rat cardiomyocytes mediated through upregulation of eNOS transcript and protein levels, and a subsequent increase in cardiomyocyte nitric oxide content ${ }^{146}$. Biglycan may modulate the inflammatory response by binding with TLR2 and TLR $4{ }^{147-150}$ and may be involved in fibrosis by binding to collagen fibrils ${ }^{125}$.

Myocardial decorin expression increases after infarction and correlates with collagen deposition, TGF-beta levels and SMAD expression ${ }^{140,142,151}$. Decorin may negatively regulate fibrosis. In vitro, addition of exogenous decorin significantly decreased collagen production 
by TGF-beta-stimulated human cardiac fibroblasts ${ }^{152}$. In vivo, decorin overexpression with an adeno-associated viral vector post myocardial infarction leads to reduced cardiac fibrosis and improves cardiac function ${ }^{153}$. Decorin may be implicated in the pathogenesis of cardiac fibrosis through binding to TGF-beta ${ }^{128}$ and by associating with collagens I and III ${ }^{154}, 155$, thus playing an important role in collagen cross-linking. Decorin DS side chain is involved in proper collagen assembly and mediates cellular adhesion to the ECM ${ }^{156}$. The biological relevance of this GAG in matrix structure is illustrated by thinner collagen fibers and increased focal adhesion in mice lacking decorin. In contrast, mice lacking only the DS side chain have thicker collagen fibrils ${ }^{156}$. Much like biglycan, decorin can act as an endogenous ligand for TLR2 and -4 stimulating the production of pro-inflammatory cytokines in macrophages ${ }^{157}$, and may play a role in activation of the myocardial inflammatory responses.

\section{CLASS II SLRPS: LUMICAN}

Lumican is ubiquitously expressed in adult mice where the heart and the eye showed the highest levels of expression ${ }^{158}$. Modification of lumican with KS to form a proteoglycan is crucial for corneal transparency ${ }^{159}$. Attachment of KS to lumican mainly occurs in the eye, whereas in other organs like the heart, lumican is present as a glycoprotein without any GAGs attached. However, increased lumican expression in the rat heart after ischemia-reperfusion does consist of both the proteoglycan and the glycoprotein, which are differentially expressed during the different phases of wound healing ${ }^{160}$. Indeed, alterations in glycosylation of decorin and lumican core protein in response to pressure overload might be important in cardiac remodeling, with a potential important role for CS/DS GAG chain-synthesizing enzymes ${ }^{161}$. Interestingly, both lumican and decorin can be cleaved by MMP-1, suggesting that proteolytic processing is very precisely regulated and crucial for proteoglycan-mediated spatiotemporal functions ${ }^{162}$.

Like biglycan and decorin, lumican is also important in modulating the inflammatory response by presenting LPS to CD14, thereby activating TLR4 in macrophages ${ }^{163}$. Further, lumican regulates neutrophil infiltration in a murine keratitis model, by interacting with CXCL1 thus creating a chemokine gradient along which these neutrophils infiltrate the injured tissue ${ }^{164}$. By interacting with collagens and other matrix components, like aggrecan and integrins, 125 lumican modulates matrix rearrangement and collagen assembly, as supported by decreased hepatic fibrosis, impaired collagen fibrillogenesis and increased matrix turnover upon liver injury in mice lacking lumican ${ }^{165}$. The diversity of this SLRP and its potential to interact with many matrix components, cytokines and growth factors together with the upregulation of lumican in experimental and clinical heart failure ${ }^{166-168}$, makes it a very interesting candidate for future research.

\section{Glycoproteins in the Heart: the Matricellular Proteins}

As described above, part of the non-structural role of the ECM is assigned to a family of structurally unrelated glycoproteins, which have been termed 'matricellular proteins' by Paul Bornstein ${ }^{169,170}$. The first proteins classified in this group of proteins were SPARC (secreted protein acidic and rich in cysteine or osteonectin), Thrombospondin-1 (TSP1) and Tenascin C; osteopontin (OPN), periostin, TSP2, TSP4, tenascin-X, CCN1 (Cyr61) and CCN2 (CTGF) were later added to this group of prototypical matricellular proteins. For the purpose of this 
review we will focus on selected matricellular proteins with a key role in cardiac remodeling (see Table 1), as a comprehensive review can be found elsewhere ${ }^{1}$.

\section{Thrombospondins}

This family of large secreted glycoproteins, consisting of five members, is subdivided into two different groups based on their structural organization and oligomerization status. Members of the first group, thrombospondin (TSP) 1 and 2, form trimers whereas the remaining members, TSP 3-5, arrange as pentamers ${ }^{171}$. Up to now, research has focused more on the extensive role of the trimeric TSPs in the heart, though some recent studies have unveiled the involvement of the pentameric TSPs -in particular TSP4- in cardiac disease. As typical matricellular proteins, TSPs are not present in the normal adult ECM, but their expression increases greatly in response to injury and during cardiac development. TSP1 is transiently expressed during cardiac development whereas TSP2 expression is abundant in connective tissues of many organs ${ }^{172}$. TSP3-5 expression during development is restricted to specific organs, such as the brain, cartilage, lung and nervous system ${ }^{172-174}$.

TSPs are of key importance in cardiac pathology. TSP1 and 2 are protective after myocardial infarction and pressure overload by preserving the cardiac matrix possibly via inhibition of MMP activity and by facilitating TGF-beta activation (specific for TSP1) ${ }^{175-177}$.TSP-1 is a potent angiostatic mediator; in the diabetic heart TSP1 has been shown to promote vascular rarefaction by enhancing angiopoietin- 2 expression ${ }^{178}$. In the ageing heart TSP2 has protective effects by activating pro-survival Akt signaling and by inhibiting MMP activity ${ }^{179}$.

Further the functional domains of TSP1 and 2 can interact with collagens and with a variety of other matrix components, like cytokines, growth factors and proteases, altering their activity ${ }^{180}$. Also, TSP1 and 2 are capable of changing focal ('strong') adhesion to a more intermediate state as suggested by its typical de-adhesive properties, similar to those of other matricellular proteins like SPARC and tenascin-C ${ }^{181}$. Lastly TSP1 and 2 demonstrate antiinflammatory properties ${ }^{182,}{ }^{183}$, mainly by increasing regulatory T-cell activation ${ }^{182,}{ }^{184}$. The increased number of regulatory T-cells was shown in murine hearts of wild type mice suffering from viral myocarditis compared to their knock out littermates ${ }^{182}$. More specifically, a CD47specific TSP peptide containing the C-terminal domain, promotes the generation of human regulatory T-cells that suppress the proliferation and cytokine production of autologous T-cells ${ }^{184}$. Other effects of TSPs on modulating the immune response are mostly prompted by TSP1/ CD36 interaction, which regulates clearance of apoptotic neutrophils ${ }^{185}$, and TSP1 initiated TGF-beta activation.

TSP4 displays similar protective effects, like TSP1 and 2, in a murine trans-aortic constriction model, suggested by the increased heart weight and accentuated reactive fibrosis observed in TSP 4 null mice ${ }^{186}$. Interestingly, Lynch et al recently suggested that the protective effects of TSP4 in the remodeling myocardium may be due to augmentation of cardiomyocyte endoplasmic reticulum function through effects on nuclear shuttling of activating transcription factor Galpha (AtfGalpha), leading to reduced protein synthesis, enhanced degradation of damaged or misfolded proteins, and selectively induced expression of protective proteins ${ }^{187}$. Upregulation of TSPs in human patients suffering from aortic stenosis (TSP2) ${ }^{176}$ or end-stage dilated cardiomyopathy (TSP4) ${ }^{188}$, further supports the importance of TSPs during cardiac remodeling. The involvement of TSPs in human cardiac disease was supported by findings demonstrating an association between single nucleotide polymorphisms (SNP) in TSPs and premature coronary athero-thrombotic disease ${ }^{189}$. 


\section{SPARC}

The classical matricellular protein SPARC also known as osteonectin, due to its original detection in the bone ${ }^{190}$, consists of a EF-hand calcium binding domain, a follistatin like domain and a kazal serine protease inhibitor domain ${ }^{191}$. SPARC has a high affinity for collagen, and facilitates collagen cross-linking. The latter is needed for proper infarct healing, as the absence of SPARC in mice caused increased cardiac rupture and dysfunction after myocardial infarction ${ }^{192}$. In contrast, this increased collagen cross-linking is detrimental in pressure overload ${ }^{193}$ and ageing ${ }^{194}$, as it induces increased diastolic dysfunction. Hence, expression of SPARC after myocardial infarction ${ }^{195}$ is beneficial whereas expression in response to pressure overload ${ }^{193}$ and as a consequence of ageing ${ }^{194}$, can be detrimental for maintaining cardiac function.

Proteolytic cleavage of SPARC by several MMPs (including MMP-2, -3, -7 and -13) modulates its function thereby increasing the affinity for collagen ${ }^{196,197}$ or releasing smaller proteolytic protein fragments that can, for instance, modulate angiogenesis ${ }^{198}$. As a classical matricellular protein, SPARC features de-adhesion properties ${ }^{181}$ and modulates the activity of various growth factors crucially involved in tissue repair, angiogenesis and fibrosis such as FGF2 ${ }^{199}$, VEGF ${ }^{200}$, platelet derived growth factor (PDGF) ${ }^{201}$, insulin like growth factor (IGF) I ${ }^{202}$ and TGF-beta ${ }^{203,204}$.

\section{TENASCINS}

Tenascins are a group of proteins consisting of four highly conserved hexameric glycoproteins termed tenascin C, X, R and W. Two members of the tenascin family, (tenascin $\mathrm{C}$ and $\mathrm{X}$ ) modulate cell migration, adhesion and growth in a typical matricellular manner ${ }^{205-}$ ${ }^{207}$. Several common functional domains are present in this group, such as EGF-like repeats, fibronectin type-III domains and a fibrinogen globe ${ }^{208}$. Tenascin $\mathrm{C}$ is markedly expressed during embryonic development, mainly in connective tissues; however its expression is suppressed in adult tissues and re-appears upon injury or remodeling, and in response to mechanical strain in fibroblasts ${ }^{209}$. Various factors, released during cardiac remodeling, like FGF2 and TGF-beta, increase tenascin $\mathrm{C}$ expression, which suggests that it may be important for regulating fibrosis and inflammation. Tenascin $\mathrm{C}$ is strongly induced in inflammatory processes and may regulate leukocyte recruitment in a context-dependent manner ${ }^{210,211}$. Moreover, it can activate TLR4 as an endogenous ligand ${ }^{212}$. Tenascin $\mathrm{C}$ loss has protective effects in post-infarction remodeling ${ }^{213}$, however, the mechanisms responsible for these actions remain poorly understood. Like all matricellular proteins, tenascin $\mathrm{C}$ can induce a de-adhesive state in fibroblasts, potentially by prohibiting integrin mediated attachment by binding fibronectin ${ }^{214}{ }^{215}$. In the heart, upregulation of tenascin $\mathrm{C}$ after myocardial infarction ${ }^{216}$, pressure overload ${ }^{217}$ or myocarditis ${ }^{218}$ is a characteristic of cardiac remodeling. Consequently, when this upregulated glycoprotein is released into the blood stream of human patients with a wide range of cardiac conditions, it becomes a reliable biomarker predicting the degree of cardiac remodeling and subsequent mortality ${ }^{219-222}$.

\section{OSTEOPONTIN}

First identified in the bone in $1985^{223}$, osteopontin (OPN) also known as bone sialoprotein I (BSP-1 or BNSP) or early T-lymphocyte activation (ETA-1), has all the characteristics of a matricellular protein and is highly up-regulated upon injury ${ }^{224}$. OPN, consists of a calcium binding domain and larger integrin-binding domains, which is cleaved by thrombin ${ }^{225}$, 
releasing an integrin binding site that is involved in leukocyte adherence ${ }^{226}$. Experimental models of cardiac fibrosis and hypertrophy resulted in marked OPN up-regulation ${ }^{227,228}$ which results in pro-hypertrophic ${ }^{229}$ and pro-fibrotic ${ }^{230}$ responses. Further, OPN expression increases upon myocardial infarction ${ }^{231}$, ageing ${ }^{232}$ and valvular disease ${ }^{233}$. This secreted glycoprotein functions as a classical non-structural matricellular protein but also has apparent cytokine-like properties ${ }^{234,235}$. OPN can interact with integrin-receptors, including the vitronectin receptor, and CD44 and hence is involved in bone mineralization, cancer biology, inflammation, wound healing, leukocyte function and recruitment, and cell survival ${ }^{234}$. Specifically in the heart, OPN up-regulation in response to myocardial infarction, primarily localized in macrophages ${ }^{236}$, is crucial for proper collagen deposition and reduction of chamber dilatation thereby protecting from adverse cardiac remodeling ${ }^{231}$. Most importantly, in patients with heart failure ${ }^{237}$, myocardial infarction ${ }^{238}$ or stenotic valvular ${ }^{239-241}$ disease, OPN plasma levels appears to be a very promising biomarker for prediction ${ }^{242}$ or progression ${ }^{243}$ of heart diseases related to adverse cardiac remodeling.

\section{Periostin}

This recently discovered glycoprotein was originally named 'osteoblast specific factor 2' due to its bone function, and later renamed due to its high abundance in the periosteum and periodontal ligament to periostin ${ }^{244}$. Periostin shares structural homology with axon guidance protein fasciclin1, containing similar sequences that allow binding to integrin's and GAGs ${ }^{245}$. Therefore, due to its high expression upon injury ${ }^{246-248}$, and potential to interact with other matrix components and integrins, periostin became accepted as a matricellular protein. Periostin is consistently elevated in response to myocardial injury ${ }^{249-252}$ and associated with fibrosis. Its up-regulation prevents cardiac rupture by stimulating fibroblast recruitment, myofibroblast transdifferentation and collagen deposition ${ }^{253,254}$. Indeed, experimentally controlled delivery of recombinant periostin peptide into the pericardial space in swine after myocardial infarction, results in increased fibrosis in the remote region one and twelve weeks after treatment ${ }^{255}$. In response to pressure overload, periostin also enables fibroblast recruitment, myofibroblast transdifferentation and collagen deposition, yet also induces slight cardiomyocyte hypertrophy without leading to decompensation ${ }^{253}$. Interestingly, periostin re-expression in mice after cardiac injury is selective for pathological stimuli as it is not reexpressed in response to physiological stimuli like hypertrophy induced forced swimming or voluntary wheel running exercise ${ }^{253}$. Although, levels of periostin in human patients with heart failure ${ }^{251}$ or acute myocardial infarction ${ }^{250}$ are elevated, research regarding its diagnostic or therapeutic potential in humans is still warranted.

\section{CCNs}

The CCN family consists of 6 members and owes its name to its first members: Cysteine rich protein 61 (Cyr61), Connective tissue growth factor (CTGF) and Nephroblastoma overexpressed protein (Nov), also known as CCN1, CCN2 and CCN3. They consist of an Insulin-like growth factor binding domain, a von Willebrand factor type $\mathrm{C}$ repeat and a single TSR domain ${ }^{256}$. Although originally considered as growth factors, many studies over the past decades have demonstrated them to act as modulators of cell-ECM adhesion through their interactions with integrins, HS proteoglycans, growth factors and cytokines ${ }^{257}$. Since their identification as matricellular proteins, $\mathrm{CCN}$ s have been studied quite extensively in heart disease. Almost all CCNs members show marked up-regulation in response to injury. $\mathrm{CCN} 2$ is the most comprehensively studied member of the $\mathrm{CCN}$ family in relation to 
cardiac disease. The evident up-regulation of CCN2 in response to myocardial infarction 258 and pressure overload ${ }^{259-261}$ is essential for potentiating TGF-beta signaling, stimulating survival of cardiomyocytes and enabling proper angiogenic and fibrotic responses, both in myocardial infarction ${ }^{262-264}$ and in response to pressure overload ${ }^{265-269}$. In contrast, CCN5 over-expression, diminishes the hypertrophic and fibrotic response following pressure overload by influencing TGF-beta/ SMAD3 signaling ${ }^{268}$. Further, increased expression of CCN1 in response to myocardial infarction or pressure overload ${ }^{270}$ may modulate phenotype and function of leukocytes, cardiomyocytes and fibroblasts ${ }^{271}$. Overexpression of CCN1 in experimental autoimmune myocarditis confirms the potential role of CCN1 on leukocyte behavior by decreasing cardiac inflammation ${ }^{272,273}$. Finally, although the in vivo effects of CCN4 up-regulation after myocardial infarction remain unclear, in vitro studies suggest a role for CCN4 in fibroblast proliferation and transduction of pro-hypertrophic and pro-survival signals in cardiomyocytes ${ }^{274-276}$. 


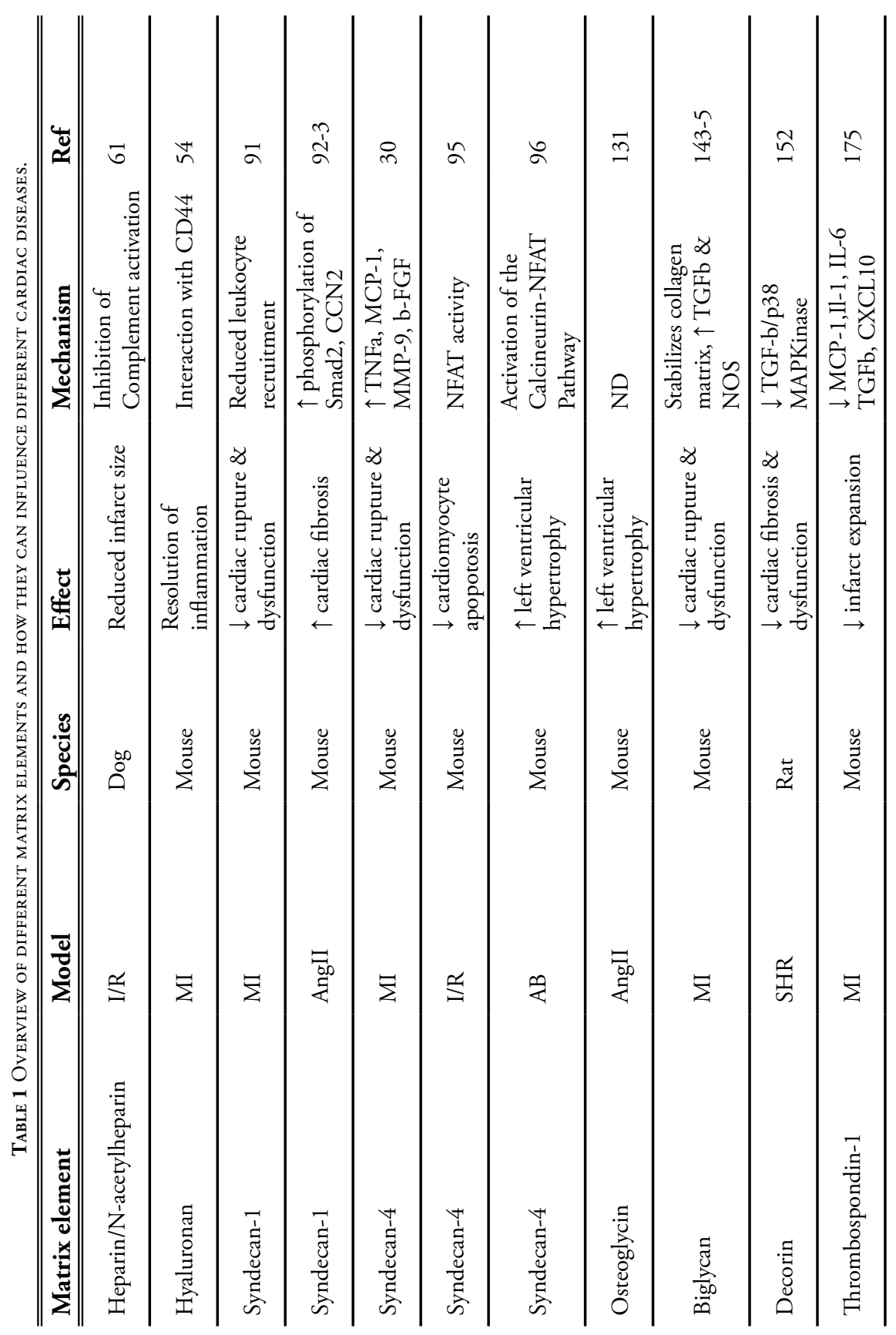




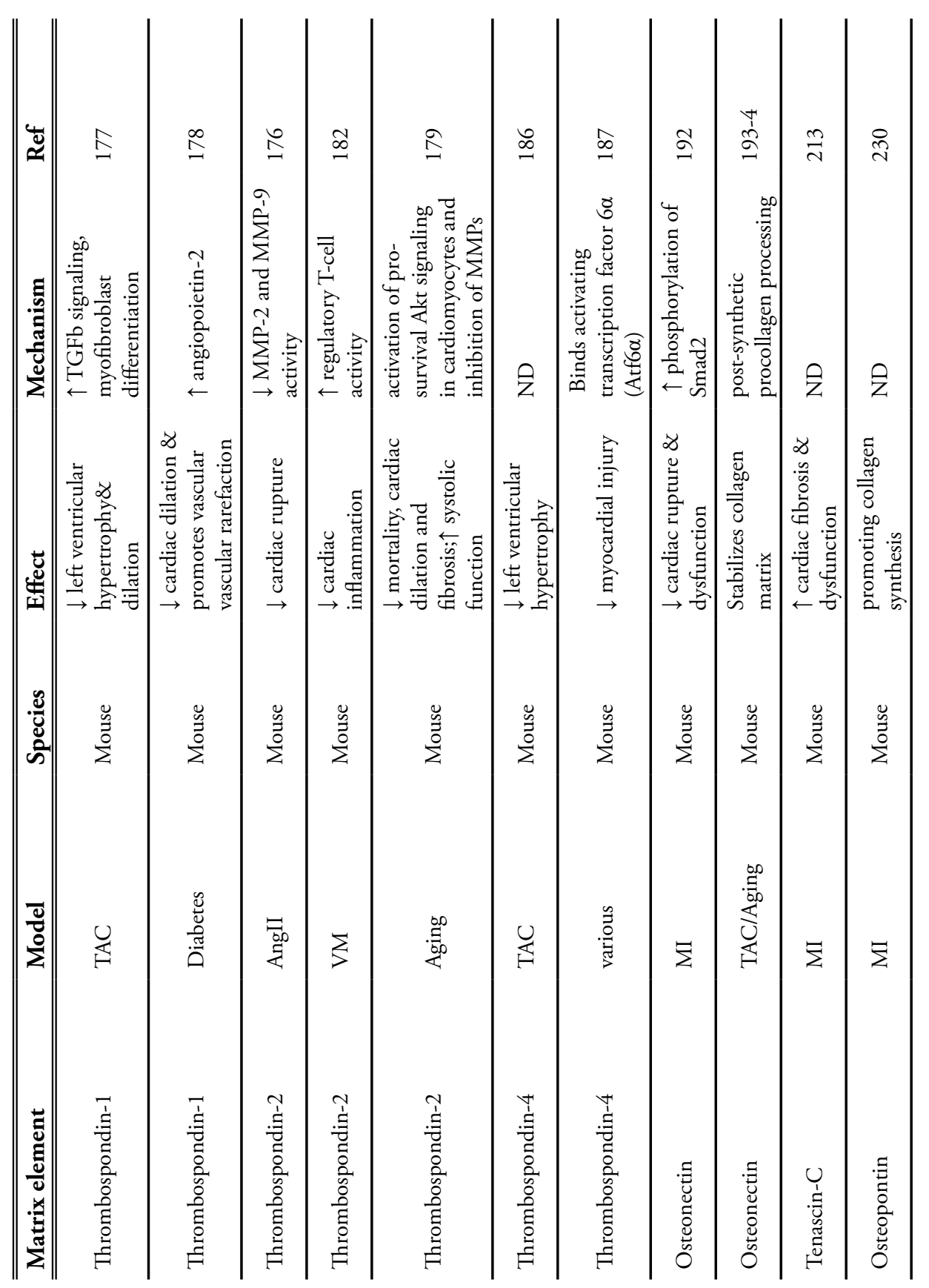




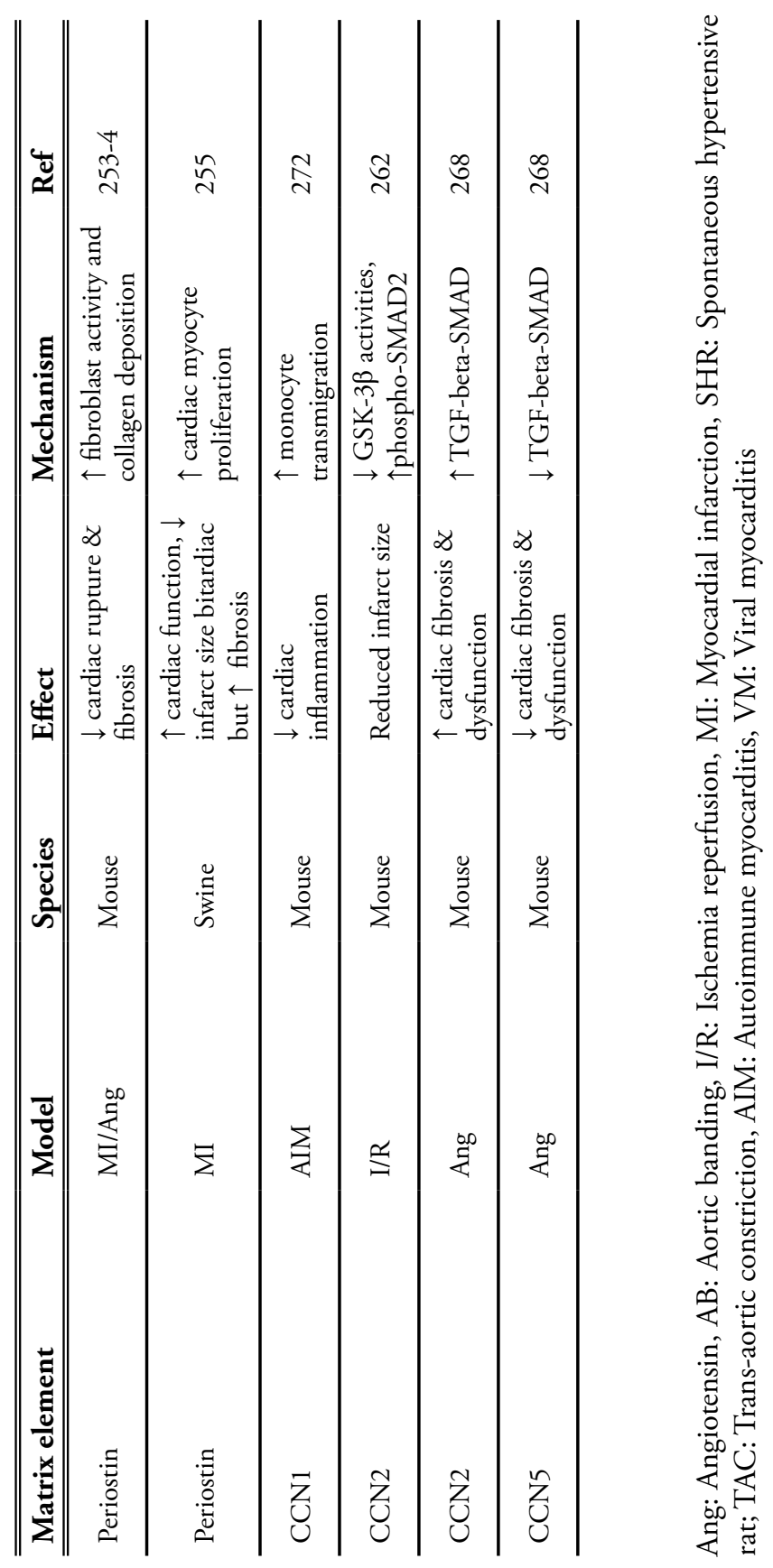




\section{Conclusion and Future Perspectives}

The complex architectural arrangement of the cardiac ECM is crucial for maintaining proper cardiac function and hence requires tight regulation. Research in the past decades has focused on identifying the various proteins and proteases that serve as orchestrators of ECM rearrangement in response to injury. This is illustrated by the critical role of proteoglycans, glycoproteins and GAGs in orchestrating cardiac ECM reorganization during tissue remodeling and in regulation of cardiac inflammation, angiogenesis and fibrosis (Figure 3). In line with the search for new clinically relevant GAGs, proteoglycans or glycoproteins in the cardiovascular field, we propose focusing on some promising candidates, such as perlecan, versican, hyaluronan, SLRPs like lumican, decorin and biglycan, but also the less known SLRPs like asporin, osteoglycin and epiphycan. Understanding their biochemical structure, in relation to their biological function, may lead to the development of new biochemical structures or compounds with great therapeutic potential for patients with heart disease.

\section{HEALTHY MYOCARDIUM}

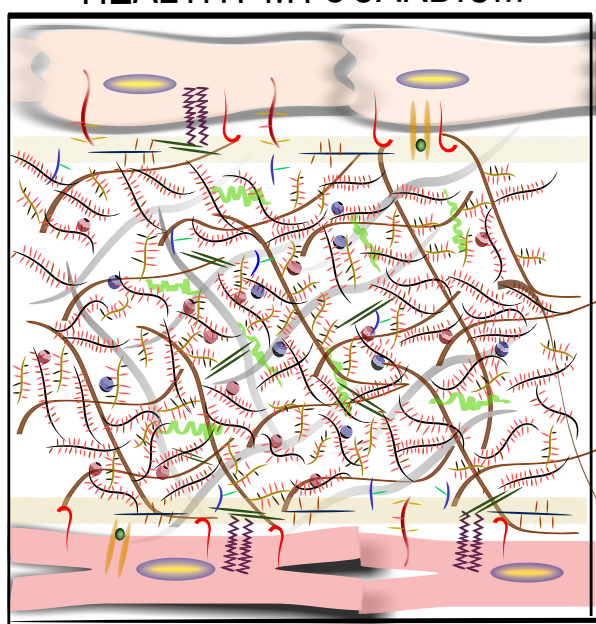

MYOCARDIAL INFARCTION

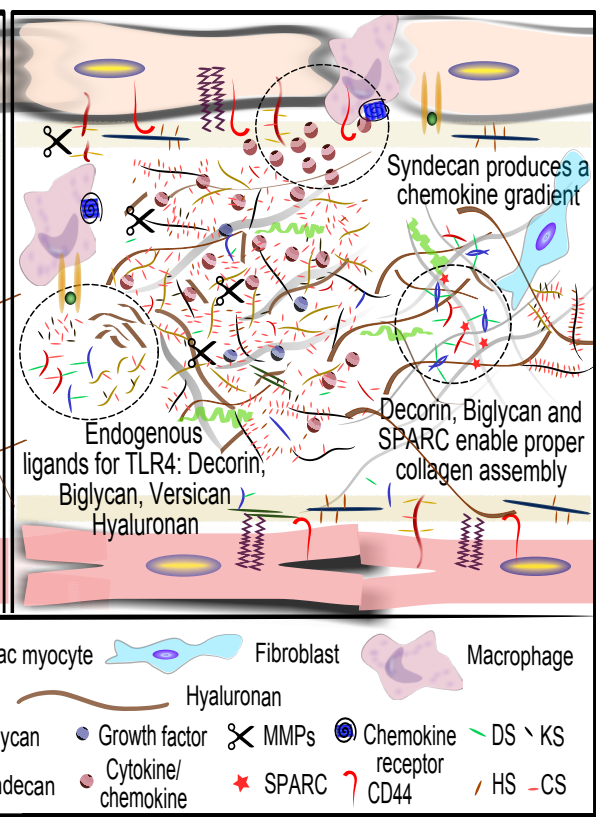

Figure 3 Complex Cardiac eXtracellular matrix (ECM) With POTENTIAL FUNCTIONS Of SOME Residing MATRIX ELEMENTS.

In healthy myocardium, the ECM forms a complex architectural meshwork and cytokine reservoir, through the close interaction of all matrix components. These include hyaluronan, CD44, collagens, hyalectans, basement membrane proteoglycans, fibronectin, and integrins. On cardiac damage, macrophages invade the cardiac tissue via interactions with ECM components hyaluronan and fibronectin, in turn secreting proteases that degrade the ECM and releasing cytokines bound in the matrix. The degraded ECM elements may further amplify the immune response by either stimulating important danger signal receptors such as TLR-4 (eg, hyaluronan, decorin, and versican) or producing chemokine gradients for the recruitment of leukocytes (eg, syndecan). Furthermore, proteoglycans, such as decorin and biglycan, and glycoproteins, such as SPARC, enable proper collagen assembly. An independent role of glycosaminoglycans (CS, DS, and HS) is starting to emerge, further elaborating the extensive repertoire of the ECM in health and disease. CS indicates chondroitin sulfate; DS, dermatan sulfate; HS, heparan sulfate; KS, keratan sulfate; and TLR-4, toll-like receptor-4. 
Up to now, the remarkable variety in function of many glycoproteins, as well as of the less well-studied proteoglycans, has been primarily attributed to their assortment of active protein domains, which can be molded by process-specific proteases to increasing their functional range. We believe that sugars, like glycans and GAGs, are crucial in directing, changing and impending proteolytic cleavage of proteins, customizing them to environmental needs and as a result increasing their domain-based-functions. Glycosylation is a much more comprehensive explanation as to how glycoproteins and proteoglycans broaden their functional range and contribute to the plasticity of the cardiac ECM. However research regarding the role of sugars, either alone or attached to a protein backbone, and their spatio-temporal function is still in an early phase, with a focus on the role of total GAG or proteoglycan content in the heart. It is the biochemically variable non-template driven sugars, together with their position on the protein, that tremendously enhance potential interactions with other matrix proteins, growth factors and growth factor receptors. Yet there are challenges to be faced. GAGs are also subjected to specific degrading enzymes changing their appearance and function ${ }^{277-279}$. Hence, looking at the total GAG or proteoglycan content introduces difficulties in attributing functionality. So how do we address the plasticity of these proteins and sugars in the ever-changing cardiac ECM? When investigating the role of specific proteoglycans, glycoproteins or GAGs in transgenic animals, the type and range of glycosylation of the studied protein could be identified. The extent of glycosylation could be determined by using specific polysaccharide lyases ${ }^{280}$ or preferably Mass Spectometry ${ }^{281}$. Care must be taken when linking in vivo studies with in vitro experiments, since the glycosylation pattern can differ significantly. Further, protein epitopes or sugars, to which newly identified functions can be ascribed, should be identified. A further obstacle is understanding the plasticity of the protein over time, in animal disease models. In reality, many different cell types produce undefined GAG/ glycans structures, hence undefined glycoprotein and proteoglycan structures, which together with proteolytic processing can influence protein appearance and function over time. Therefore specific attention is needed in understanding what drives this tailor-made cell specific glycosylation. How is it directed? Where can we intervene? Cell-specific and inducible transgenic animal models studying the role of specific enzymes in the ER and Golgi could give more insight in the sequential and mutual role of the sixteen currently identified and differentially expressed enzymes, hence explain a crucial determinant of ECM plasticity upon injury. Understanding why and when these seemingly random modification occur, may lead to the discovery of very specific glycosylation profiles allowing well-tailored disease interventions. 


\section{REFERENCES}

Frangogiannis NG. Matricellular proteins in cardiac adaptation and disease. Physiol Rev. 2012;92:635688

Okamoto H, Imanaka-Yoshida K. Matricellular proteins: New molecular targets to prevent heart failure. Cardiovasc Ther. 2012;30:e198-209

Kehat I, Molkentin JD. Molecular pathways underlying cardiac remodeling during pathophysiological stimulation. Circulation. 2010;122:2727-2735

Heymans S. Inflammation and cardiac remodeling during viral myocarditis. Ernst Schering Res Found Workshop. 2006:197-218

Bornstein P, Sage EH. Matricellular proteins: Extracellular modulators of cell function. Curr Opin Cell Biol. 2002;14:608-616

Spinale FG, Janicki JS, Zile MR. Membrane-associated matrix proteolysis and heart failure. Circ Res. 2013;112:195-208

Mitra N, Sinha S, Ramya TN, Surolia A. N-linked oligosaccharides as outfitters for glycoprotein folding, form and function. Trends Biochem Sci. 2006;31:156-163

Nothaft H, Szymanski CM. Protein glycosylation in bacteria: Sweeter than ever. Nat Rev Microbiol. 2010;8:765-778

Zhang Y, Yin H, Lu H. Recent progress in quantitative glycoproteomics. Glycoconj J. 2012;29:249-258

DeAngelis PL. Evolution of glycosaminoglycans and their glycosyltransferases: Implications for the extracellular matrices of animals and the capsules of pathogenic bacteria. Anat Rec. 2002;268:317326

Kawaguchi T, Decho AW. Biochemical characterization of cyanobacterial extracellular polymers (eps) from modern marine stromatolites (bahamas). Prep Biochem Biotechnol. 2000;30:321-330

Rudd PM, Elliott T, Cresswell P, Wilson IA, Dwek RA. Glycosylation and the immune system. Science. 2001;291:2370-2376

3 Middleton J, Patterson AM, Gardner L, Schmutz C, Ashton BA. Leukocyte extravasation: Chemokine transport and presentation by the endothelium. Blood. 2002;100:3853-3860

Parodi AJ. Role of $n$-oligosaccharide endoplasmic reticulum processing reactions in glycoprotein folding and degradation. Biochem J. 2000;348 Pt 1:1-13

Van den Steen P, Rudd PM, Dwek RA, Opdenakker G. Concepts and principles of o-linked glycosylation. Crit Rev Biochem Mol Biol. 1998;33:151-208

Spiro RG. Protein glycosylation: Nature, distribution, enzymatic formation, and disease implications of glycopeptide bonds. Glycobiology. 2002;12:43R-56R

Shriver Z, Raguram S, Sasisekharan R. Glycomics: A pathway to a class of new and improved therapeutics. Nat Rev Drug Discov. 2004;3:863-873

Prehm P. Identification and regulation of the eukaryotic hyaluronate synthase. Ciba Found Symp. 1989;143:21-30; discussion 30-40, 281-285

Laurent TC, Fraser JR. Hyaluronan. Faseb J. 1992;6:2397-2404

Ohtsubo K, Marth JD. Glycosylation in cellular mechanisms of health and disease. Cell. 2006;126:855867

Freeze HH. Understanding human glycosylation disorders: Biochemistry leads the charge. J Biol Chem. 2013;288:6936-6945

Zhang L, David G, Esko JD. Repetitive ser-gly sequences enhance heparan sulfate assembly in proteoglycans. J Biol Chem. 1995;270:27127-27135

de Graffenried CL, Bertozzi CR. The roles of enzyme localisation and complex formation in glycan assembly within the golgi apparatus. Curr Opin Cell Biol. 2004;16:356-363

Nalivaeva NN, Turner AJ. Post-translational modifications of proteins: Acetylcholinesterase as a model system. Proteomics. 2001;1:735-747

Aviezer D, Levy E, Safran M, Svahn C, Buddecke E, Schmidt A, David G, Vlodavsky I, Yayon A. Differential structural requirements of heparin and heparan sulfate proteoglycans that promote binding of basic fibroblast growth factor to its receptor. J Biol Chem. 1994;269:114-121

26 Aviezer D, Hecht D, Safran M, Eisinger M, David G, Yayon A. Perlecan, basal lamina proteoglycan, promotes basic fibroblast growth factor-receptor binding, mitogenesis, and angiogenesis. Cell. 1994;79:1005-1013

Prydz K, Dalen KT. Synthesis and sorting of proteoglycans. J Cell Sci. 2000;113 Pt 2:193-205 Bernfield M, Gotte M, Park PW, Reizes O, Fitzgerald ML, Lincecum J, Zako M. Functions of cell surface heparan sulfate proteoglycans. Annu Rev Biochem. 1999;68:729-777 
29 Kusche-Gullberg M, Kjellen L. Sulfotransferases in glycosaminoglycan biosynthesis. Curr Opin Struct Biol. 2003;13:605-611

30 Matsui Y, Ikesue M, Danzaki K, Morimoto J, Sato M, Tanaka S, Kojima T, Tsutsui H, Uede T. Syndecan-4 prevents cardiac rupture and dysfunction after myocardial infarction. Circ Res. 2011;108:1328-1339

31 Landsteiner K. Individual differences in human blood. Science. 1931;73:403-409

32 Jin L, Abrahams JP, Skinner R, Petitou M, Pike RN, Carrell RW. The anticoagulant activation of antithrombin by heparin. Proc Natl Acad Sci U S A. 1997;94:14683-14688

33 Guerrini M, Beccati D, Shriver Z, Naggi A, Viswanathan K, Bisio A, Capila I, Lansing JC, Guglieri S, Fraser B, Al-Hakim A, Gunay NS, Zhang Z, Robinson L, Buhse L, Nasr M, Woodcock J, Langer R, Venkataraman G, Linhardt RJ, Casu B, Torri G, Sasisekharan R. Oversulfated chondroitin sulfate is a contaminant in heparin associated with adverse clinical events. Nat Biotechnol. 2008;26:669-675

34 Beccati D, Roy S, Lech M, Ozug J, Schaeck J, Gunay NS, Zouaoui R, Capila I, Kaundinya GV. Identification of a novel structure in heparin generated by sequential oxidative-reductive treatment. Anal Chem. 2012;84:5091-5096

35 Bjornsson TD, Schneider DE, Hecht AR. Effects of $n$-deacetylation and $n$-desulfation of heparin on its anticoagulant activity and in vivo disposition. J Pharmacol Exp Ther. 1988;245:804-808

36 Casu B, Vlodavsky I, Sanderson RD. Non-anticoagulant heparins and inhibition of cancer. Pathophysiol Haemost Thromb. 2008;36:195-203

37 Karl Meyer JWP. The polysaccharide of the vitreous humor. Journal of Biological Chemistry. 1934;107:629-634

38 Hellstrom M, Johansson B, Engstrom-Laurent A. Hyaluronan and its receptor $\mathrm{cd} 44$ in the heart of newborn and adult rats. Anat Rec A Discov Mol Cell Evol Biol. 2006;288:587-592

39 Rodgers LS, Lalani S, Hardy KM, Xiang X, Broka D, Antin PB, Camenisch TD. Depolymerized hyaluronan induces vascular endothelial growth factor, a negative regulator of developmental epithelial-tomesenchymal transformation. Circ Res. 2006;99:583-589

40 Law $\mathrm{CH}$, Li JM, Chou HC, Chen YH, Chan HL. Hyaluronic acid-dependent protection in h9c2 cardiomyocytes: A cell model of heart ischemia-reperfusion injury and treatment. Toxicology. 2013;303:54-71

41 Chowdhury B, Hemming R, Hombach-Klonisch S, Flamion B, Triggs-Raine B. Murine hyaluronidase 2 deficiency results in extracellular hyaluronan accumulation and severe cardiopulmonary dysfunction. J Biol Chem. 2013;288:520-528

42 Chopra A, Lin V, McCollough A, Atzet S, Prestwich GD, Wechsler AS, Murray ME, Oake SA, Kresh JY, Janmey PA. Reprogramming cardiomyocyte mechanosensing by crosstalk between integrins and hyaluronic acid receptors. J Biomech. 2012;45:824-831

43 Hellman U, Malm L, Ma LP, Larsson G, Morner S, Fu M, Engstrom-Laurent A, Waldenstrom A. Growth factor pdgf-bb stimulates cultured cardiomyocytes to synthesize the extracellular matrix component hyaluronan. PLoS One. 2010;5:e14393

44 McDonald JA, Camenisch TD. Hyaluronan: Genetic insights into the complex biology of a simple polysaccharide. Glycoconj J. 2002;19:331-339

45 Baldwin HS, Lloyd TR, Solursh M. Hyaluronate degradation affects ventricular function of the early postlooped embryonic rat heart in situ. Circ Res. 1994;74:244-252

46 Wheatley SC, Isacke CM, Crossley PH. Restricted expression of the hyaluronan receptor, cd44, during postimplantation mouse embryogenesis suggests key roles in tissue formation and patterning. Development. 1993;119:295-306

47 Boudreau N, Turley E, Rabinovitch M. Fibronectin, hyaluronan, and a hyaluronan binding protein contribute to increased ductus arteriosus smooth muscle cell migration. Dev Biol. 1991;143:235-247

48 Camenisch TD, Spicer AP, Brehm-Gibson T, Biesterfeldt J, Augustine ML, Calabro A, Jr., Kubalak S, Klewer SE, McDonald JA. Disruption of hyaluronan synthase-2 abrogates normal cardiac morphogenesis and hyaluronan-mediated transformation of epithelium to mesenchyme. J Clin Invest. 2000;106:349-360

49 Hellman U, Hellstrom M, Morner S, Engstrom-Laurent A, Aberg AM, Oliviero P, Samuel JL, Waldenstrom

A. Parallel up-regulation of fgf-2 and hyaluronan during development of cardiac hypertrophy in rat. Cell Tissue Res. 2008;332:49-56

50 Waldenstrom A, Martinussen HJ, Gerdin B, Hallgren R. Accumulation of hyaluronan and tissue edema in experimental myocardial infarction. J Clin Invest. 1991;88:1622-1628

51 Waldenstrom A, Fohlman J, Ilback NG, Ronquist G, Hallgren R, Gerdin B. Coxsackie b3 myocarditis induces a decrease in energy charge and accumulation of hyaluronan in the mouse heart. Eur $\mathrm{J}$ Clin Invest. 1993;23:277-282 
52 West DC, Hampson IN, Arnold F, Kumar S. Angiogenesis induced by degradation products of hyaluronic acid. Science. 1985;228:1324-1326

53 Jiang D, Liang J, Noble PW. Hyaluronan in tissue injury and repair. Annu Rev Cell Dev Biol. 2007;23:435461

54 Huebener P, Abou-Khamis T, Zymek P, Bujak M, Ying X, Chatila K, Haudek S, Thakker G, Frangogiannis NG. Cd44 is critically involved in infarct healing by regulating the inflammatory and fibrotic response. J Immunol. 2008;180:2625-2633 Abatangelo G, Martelli M, Vecchia P. Healing of hyaluronic acid-enriched wounds: Histological observations. J Surg Res. 1983;35:410-416

56 Meran S, Thomas DW, Stephens P, Enoch S, Martin J, Steadman R, Phillips AO. Hyaluronan facilitates transforming growth factor-beta1-mediated fibroblast proliferation. J Biol Chem. 2008;283:65306545

Simpson RM, Meran S, Thomas D, Stephens P, Bowen T, Steadman R, Phillips A. Age-related changes in pericellular hyaluronan organization leads to impaired dermal fibroblast to myofibroblast differentiation. Am J Pathol. 2009;175:1915-1928

58 Simpson RM, Wells A, Thomas D, Stephens P, Steadman R, Phillips A. Aging fibroblasts resist phenotypic maturation because of impaired hyaluronan-dependent cd44/epidermal growth factor receptor signaling. Am J Pathol. 2010;176:1215-1228

Webber J, Meran S, Steadman R, Phillips A. Hyaluronan orchestrates transforming growth factorbeta1-dependent maintenance of myofibroblast phenotype. J Biol Chem. 2009;284:9083-9092

Webber J, Jenkins RH, Meran S, Phillips A, Steadman R. Modulation of tgfbeta1-dependent myofibroblast differentiation by hyaluronan. Am J Pathol. 2009;175:148-160

Friedrichs GS, Kilgore KS, Manley PJ, Gralinski MR, Lucchesi BR. Effects of heparin and n-acetyl heparin on ischemia/reperfusion-induced alterations in myocardial function in the rabbit isolated heart. Circ Res. 1994;75:701-710

62 Black SC, Gralinski MR, Friedrichs GS, Kilgore KS, Driscoll EM, Lucchesi BR. Cardioprotective effects of heparin or $n$-acetylheparin in an in vivo model of myocardial ischaemic and reperfusion injury. Cardiovasc Res. 1995;29:629-636

Gralinski MR, Driscoll EM, Friedrichs GS, DeNardis MR, Lucchesi BR. Reduction of myocardial necrosis after glycosaminoglycan administration: Effects of a single intravenous administration of heparin or n-acetylheparin 2 hours before regional ischemia and reperfusion. J Cardiovasc Pharmacol Ther. 1996;1:219-228

64 Kilgore KS, Naylor KB, Tanhehco EJ, Park JL, Booth EA, Washington RA, Lucchesi BR. The semisynthetic polysaccharide pentosan polysulfate prevents complement-mediated myocardial injury in the rabbit perfused heart. J Pharmacol Exp Ther. 1998;285:987-994 Tanhehco EJ, Kilgore KS, Naylor KB, Park JL, Booth EA, Lucchesi BR. Reduction of myocardial infarct size after ischemia and reperfusion by the glycosaminoglycan pentosan polysulfate. J Cardiovasc Pharmacol. 1999;34:153-161 Chan CK, Rolle MW, Potter-Perigo S, Braun KR, Van Biber BP, Laflamme MA, Murry CE, Wight TN. Differentiation of cardiomyocytes from human embryonic stem cells is accompanied by changes in the extracellular matrix production of versican and hyaluronan. J Cell Biochem. 2010;111:585-596 Hatano S, Kimata K, Hiraiwa N, Kusakabe M, Isogai Z, Adachi E, Shinomura T, Watanabe H. Versican/ pg-m is essential for ventricular septal formation subsequent to cardiac atrioventricular cushion development. Glycobiology. 2012;22:1268-1277 Peal DS, Burns CG, Macrae CA, Milan D. Chondroitin sulfate expression is required for cardiac atrioventricular canal formation. Dev Dyn. 2009;238:3103-3110

Baasanjav S, Al-Gazali L, Hashiguchi T, Mizumoto S, Fischer B, Horn D, Seelow D, Ali BR, Aziz SA, Langer R, Saleh AA, Becker C, Nurnberg G, Cantagrel V, Gleeson JG, Gomez D, Michel JB, Stricker S, Lindner TH, Nurnberg P, Sugahara K, Mundlos S, Hoffmann K. Faulty initiation of proteoglycan synthesis causes cardiac and joint defects. Am J Hum Genet. 2011;89:15-27

70 Stephens EH, Saltarrelli JG, Baggett LS, Nandi I, Kuo JJ, Davis AR, Olmsted-Davis EA, Reardon MJ, Morrisett JD, Grande-Allen KJ. Differential proteoglycan and hyaluronan distribution in calcified aortic valves. Cardiovasc Pathol. 2011;20:334-342

71 Gupta V, Tseng H, Lawrence BD, Grande-Allen KJ. Effect of cyclic mechanical strain on glycosaminoglycan and proteoglycan synthesis by heart valve cells. Acta Biomater. 2009;5:531-540

72 Kruithof BP, Krawitz SA, Gaussin V. Atrioventricular valve development during late embryonic and postnatal stages involves condensation and extracellular matrix remodeling. Dev Biol. 2007;302:208217

73 Cabrera GH, Fernandez I, Dominguez M, Clarke LA. Left ventricular aneurysm in an adult patient 
with mucopolysaccharidosis type i: Comment on pathogenesis of a novel complication. Mol Genet Metab. 2012;106:470-473

74 Stephens EH, Shangkuan J, Kuo JJ, Carroll JL, Kearney DL, Carberry KE, Fraser CD, Jr., Grande-Allen $\mathrm{KJ}$. Extracellular matrix remodeling and cell phenotypic changes in dysplastic and hemodynamically altered semilunar human cardiac valves. Cardiovasc Pathol. 2011;20:e157-167

75 Prante C, Milting H, Kassner A, Farr M, Ambrosius M, Schon S, Seidler DG, Banayosy AE, Korfer R, Kuhn J, Kleesiek K, Gotting C. Transforming growth factor beta1-regulated xylosyltransferase i activity in human cardiac fibroblasts and its impact for myocardial remodeling. J Biol Chem. 2007;282:2644126449

76 Mizutani K, Kawashima S, Ueyama T, Sakoda T, Takeuchi S, Kobayashi S, Yokoyama M, Hayashi Y, Itoh $\mathrm{H}$. Heparin and heparan sulfate inhibit extracellular signal-regulated kinase activation and myocardial cell hypertrophy induced by endothelin-1. Kobe J Med Sci. 2001;47:47-58

77 Huynh MB, Morin C, Carpentier G, Garcia-Filipe S, Talhas-Perret S, Barbier-Chassefiere V, van Kuppevelt TH, Martelly I, Albanese P, Papy-Garcia D. Age-related changes in rat myocardium involve altered capacities of glycosaminoglycans to potentiate growth factor functions and heparan sulfatealtered sulfation. J Biol Chem. 2012;287:11363-11373

78 Friebe VM, Mikulis B, Kole S, Ruffing CS, Sacks MS, Vyavahare NR. Neomycin enhances extracellular matrix stability of glutaraldehyde crosslinked bioprosthetic heart valves. J Biomed Mater Res B Appl Biomater. 2011;99:217-229

79 Mataveli FD, Han SW, Nader HB, Mendes A, Kanishiro R, Tucci P, Lopes AC, Baptista-Silva JC, Marolla AP, de Carvalho LP, Denapoli PM, Pinhal MA. Long-term effects for acute phase myocardial infarct vegf165 gene transfer cardiac extracellular matrix remodeling. Growth Factors. 2009;27:22-31

80 Shetlar MR, Shetlar CL, Kischer CW. Healing of myocardial infarction in animal models. Tex Rep Biol Med. 1979;39:339-355

81 Shetlar MR, Davitt WF, Rosett RL, Crass MF, 3rd, Lautsch EV, Kischer C. Glycosaminoglycan changes in healing myocardial infarction. Proc Soc Exp Biol Med. 1978;158:210-214

82 Yamauchi H, Desgranges P, Lecerf L, Papy-Garcia D, Tournaire MC, Moczar M, Loisance D, Barritault D. New agents for the treatment of infarcted myocardium. Faseb J. 2000;14:2133-2134

83 Akimoto H, Ito H, Tanaka M, Adachi S, Hata M, Lin M, Fujisaki H, Marumo F, Hiroe M. Heparin and heparan sulfate block angiotensin ii-induced hypertrophy in cultured neonatal rat cardiomyocytes. A possible role of intrinsic heparin-like molecules in regulation of cardiomyocyte hypertrophy. Circulation. 1996;93:810-816

84 Theocharis AD, Skandalis SS, Tzanakakis GN, Karamanos NK. Proteoglycans in health and disease: Novel roles for proteoglycans in malignancy and their pharmacological targeting. Febs J. 2010;277:3904-3923

85 Fears CY, Woods A. The role of syndecans in disease and wound healing. Matrix Biol. 2006;25:443-456

86 Couchman JR. Syndecans: Proteoglycan regulators of cell-surface microdomains? Nat Rev Mol Cell Biol. 2003;4:926-937

87 Finsen AV, Woldbaek PR, Li J, Wu J, Lyberg T, Tonnessen T, Christensen G. Increased syndecan expression following myocardial infarction indicates a role in cardiac remodeling. Physiol Genomics. 2004;16:301-308

88 Endo C, Kusachi S, Ninomiya Y, Yamamoto K, Murakami M, Murakami T, Shinji T, Koide N, Kondo J, Tsuji T. Time-dependent increases in syndecan-1 and fibroglycan messenger rna expression in the infarct zone after experimentally induced myocardial infarction in rats. Coron Artery Dis. 1997;8:155-161

89 Li J, Brown LF, Laham RJ, Volk R, Simons M. Macrophage-dependent regulation of syndecan gene expression. Circ Res. 1997;81:785-796

90 Lei J, Xue SN, Wu W, Zhou SX, Zhang YL, Yuan GY, Wang JF. Increased level of soluble syndecan-1 in serum correlates with myocardial expression in a rat model of myocardial infarction. Mol Cell Biochem. 2012;359:177-182

91 Vanhoutte D, Schellings MW, Gotte M, Swinnen M, Herias V, Wild MK, Vestweber D, Chorianopoulos E, Cortes V, Rigotti A, Stepp MA, Van de Werf F, Carmeliet P, Pinto YM, Heymans S. Increased expression of syndecan-1 protects against cardiac dilatation and dysfunction after myocardial infarction. Circulation. 2007;115:475-482

92 Schellings MW, Vanhoutte D, van Almen GC, Swinnen M, Leenders JJ, Kubben N, van Leeuwen RE, Hofstra L, Heymans S, Pinto YM. Syndecan-1 amplifies angiotensin ii-induced cardiac fibrosis. Hypertension. 2010;55:249-256

93 Frangogiannis NG. Syndecan-1: A critical mediator in cardiac fibrosis. Hypertension. 2010;55:233-235

94 Xie J, Wang J, Li R, Dai Q, Yong Y, Zong B, Xu Y, Li E, Ferro A, Xu B. Syndecan-4 over-expression preserves cardiac function in a rat model of myocardial infarction. J Mol Cell Cardiol. 2012;53:250-258 
95 Echtermeyer F, Harendza T, Hubrich S, Lorenz A, Herzog C, Mueller M, Schmitz M, Grund A, Larmann J, Stypmann J, Schieffer B, Lichtinghagen R, Hilfiker-Kleiner D, Wollert KC, Heineke J, Theilmeier G. Syndecan-4 signalling inhibits apoptosis and controls nfat activity during myocardial damage and remodelling. Cardiovasc Res. 2011;92:123-131

96 Finsen AV, Lunde IG, Sjaastad I, Ostli EK, Lyngra M, Jarstadmarken HO, Hasic A, Nygard S, WilcoxAdelman SA, Goetinck PF, Lyberg T, Skrbic B, Florholmen G, Tonnessen T, Louch WE, Djurovic S, Carlson CR, Christensen G. Syndecan-4 is essential for development of concentric myocardial hypertrophy via stretch-induced activation of the calcineurin-nfat pathway. PLoS One. 2011;6:e28302 lozzo RV, Murdoch AD. Proteoglycans of the extracellular environment: Clues from the gene and protein side offer novel perspectives in molecular diversity and function. Faseb J. 1996;10:598-614

98 Sztrolovics R, Grover J, Cs-Szabo G, Shi SL, Zhang Y, Mort JS, Roughley PJ. The characterization of versican and its message in human articular cartilage and intervertebral disc. J Orthop Res. 2002;20:257-266

99 Hardingham TE, Fosang AJ. Proteoglycans: Many forms and many functions. Faseb J. 1992;6:861-870

100 lozzo RV. Perlecan: A gem of a proteoglycan. Matrix Biol. 1994;14:203-208

101 Cooley MA, Fresco VM, Dorlon ME, Twal WO, Lee NV, Barth JL, Kern CB, Iruela-Arispe ML, Argraves WS. Fibulin-1 is required during cardiac ventricular morphogenesis for versican cleavage, suppression of erbb2 and erk1/2 activation, and to attenuate trabecular cardiomyocyte proliferation. Dev Dyn. 2012;241:303-314

102 Dupuis LE, McCulloch DR, McGarity JD, Bahan A, Wessels A, Weber D, Diminich AM, Nelson CM, Apte SS, Kern CB. Altered versican cleavage in adamts 5 deficient mice; a novel etiology of myxomatous valve disease. Dev Biol. 2011;357:152-164

103 Barascuk N, Genovese F, Larsen L, Byrjalsen I, Zheng Q, Sun S, Hosbond S, Poulsen TS, Diederichsen A, Jensen JM, Mickley H, Register TC, Rasmussen LM, Leeming DJ, Christiansen C, Karsdal MA. A mmp derived versican neo-epitope is elevated in plasma from patients with atherosclerotic heart disease. Int J Clin Exp Med. 2013;6:174-184

104 Krishnamurthy VK, Opoka AM, Kern CB, Guilak F, Narmoneva DA, Hinton RB. Maladaptive matrix remodeling and regional biomechanical dysfunction in a mouse model of aortic valve disease. Matrix Biol. 2012;31:197-205

105 Wu YJ, La Pierre DP, Wu J, Yee AJ, Yang BB. The interaction of versican with its binding partners. Cell Res. 2005;15:483-494

106 Kawashima H, Hirose M, Hirose J, Nagakubo D, Plaas AH, Miyasaka M. Binding of a large chondroitin sulfate/dermatan sulfate proteoglycan, versican, to I-selectin, p-selectin, and cd44. J Biol Chem. 2000;275:35448-35456

107 Theocharis AD. Versican in health and disease. Connect Tissue Res. 2008;49:230-234

108 Kim S, Takahashi H, Lin WW, Descargues P, Grivennikov S, Kim Y, Luo JL, Karin M. Carcinoma-produced factors activate myeloid cells through tIr2 to stimulate metastasis. Nature. 2009;457:102-106

109 Wight TN. Arterial remodeling in vascular disease: A key role for hyaluronan and versican. Front Biosci. 2008;13:4933-4937

110 de La Motte CA, Hascall VC, Calabro A, Yen-Lieberman B, Strong SA. Mononuclear leukocytes preferentially bind via cd44 to hyaluronan on human intestinal mucosal smooth muscle cells after virus infection or treatment with poly(i.C). J Biol Chem. 1999;274:30747-30755

111 Frey H, Schroeder N, Manon-Jensen T, lozzo RV, Schaefer L. Biological interplay between proteoglycans and their innate immune receptors in inflammation. Febs J. 2013;280:2165-2179

112 Chang MY, Chan CK, Braun KR, Green PS, O’Brien KD, Chait A, Day AJ, Wight TN. Monocyteto-macrophage differentiation: Synthesis and secretion of a complex extracellular matrix. J Biol Chem. 2012;287:14122-14135

113 Toeda K, Nakamura K, Hirohata S, Hatipoglu OF, Demircan K, Yamawaki H, Ogawa H, Kusachi S, Shiratori $Y$, Ninomiya Y. Versican is induced in infiltrating monocytes in myocardial infarction. Mol Cell Biochem. 2005;280:47-56

114 Martinez FO, Gordon S, Locati M, Mantovani A. Transcriptional profiling of the human monocyteto-macrophage differentiation and polarization: New molecules and patterns of gene expression. J Immunol. 2006;177:7303-7311

115 lozzo RV, Zoeller JJ, Nystrom A. Basement membrane proteoglycans: Modulators par excellence of cancer growth and angiogenesis. Mol Cells. 2009;27:503-513

116 Zhou Z, Wang J, Cao R, Morita H, Soininen R, Chan KM, Liu B, Cao Y, Tryggvason K. Impaired angiogenesis, delayed wound healing and retarded tumor growth in perlecan heparan sulfatedeficient mice. Cancer Res. 2004;64:4699-4702

117 Soulintzi N, Zagris N. Spatial and temporal expression of perlecan in the early chick embryo. Cells 
Tissues Organs. 2007;186:243-256

118 Zoeller JJ, McQuillan A, Whitelock J, Ho SY, lozzo RV. A central function for perlecan in skeletal muscle and cardiovascular development. J Cell Biol. 2008;181:381-394

11 Sasse P, Malan D, Fleischmann M, Roell W, Gustafsson E, Bostani T, Fan Y, Kolbe T, Breitbach M, Addicks K, Welz A, Brem G, Hescheler J, Aszodi A, Costell M, Bloch W, Fleischmann BK. Perlecan is critical for heart stability. Cardiovasc Res. 2008;80:435-444

120 lozzo RV. The family of the small leucine-rich proteoglycans: Key regulators of matrix assembly and cellular growth. Crit Rev Biochem Mol Biol. 1997;32:141-174

121 Fisher LW, Termine JD, Young MF. Deduced protein sequence of bone small proteoglycan i (biglycan) shows homology with proteoglycan ii (decorin) and several nonconnective tissue proteins in a variety of species. J Biol Chem. 1989;264:4571-4576

122 Dellett M, Hu W, Papadaki V, Ohnuma S. Small leucine rich proteoglycan family regulates multiple signalling pathways in neural development and maintenance. Dev Growth Differ. 2012;54:327-340

123 Moreth K, lozzo RV, Schaefer L. Small leucine-rich proteoglycans orchestrate receptor crosstalk during inflammation. Cell cycle. 2012;11:2084-2091

124 lozzo RV, Sanderson RD. Proteoglycans in cancer biology, tumour microenvironment and angiogenesis. J Cell Mol Med. 2011;15:1013-1031

125 Chen S, Birk DE. The regulatory roles of small leucine-rich proteoglycans in extracellular matrix assembly. Febs J. 2013;280:2120-2137

126 lozzo RV, Schaefer L. Proteoglycans in health and disease: Novel regulatory signaling mechanisms evoked by the small leucine-rich proteoglycans. Febs J. 2010;277:3864-3875

127 Cabello-Verrugio C, Santander C, Cofre C, Acuna MJ, Melo F, Brandan E. The internal region leucine-rich repeat 6 of decorin interacts with low density lipoprotein receptor-related protein-1, modulates transforming growth factor (tgf)-beta-dependent signaling, and inhibits tgf-betadependent fibrotic response in skeletal muscles. J Biol Chem. 2012;287:6773-6787

128 Hildebrand A, Romaris M, Rasmussen LM, Heinegard D, Twardzik DR, Border WA, Ruoslahti E. Interaction of the small interstitial proteoglycans biglycan, decorin and fibromodulin with transforming growth factor beta. Biochem J. 1994;302 ( Pt 2):527-534

129 Gupta V, Barzilla JE, Mendez JS, Stephens EH, Lee EL, Collard CD, Laucirica R, Weigel PH, Grande-Allen $\mathrm{KJ}$. Abundance and location of proteoglycans and hyaluronan within normal and myxomatous mitral valves. Cardiovasc Pathol. 2009;18:191-197

130 Stephens EH, Nguyen TC, Itoh A, Ingels NB, Jr., Miller DC, Grande-Allen KJ. The effects of mitral regurgitation alone are sufficient for leaflet remodeling. Circulation. 2008;118:S243-249

131 Zheng J, Chen Y, Pat B, Dell'italia LA, Tillson M, Dillon AR, Powell PC, Shi K, Shah N, Denney T, Husain A, Dell'Italia LJ. Microarray identifies extensive downregulation of noncollagen extracellular matrix and profibrotic growth factor genes in chronic isolated mitral regurgitation in the dog. Circulation. 2009;119:2086-2095

132 Petretto E, Sarwar R, Grieve I, Lu H, Kumaran MK, Muckett PJ, Mangion J, Schroen B, Benson M, Punjabi PP, Prasad SK, Pennell DJ, Kiesewetter C, Tasheva ES, Corpuz LM, Webb MD, Conrad GW, Kurtz TW, Kren V, Fischer J, Hubner N, Pinto YM, Pravenec M, Aitman TJ, Cook SA. Integrated genomic approaches implicate osteoglycin (ogn) in the regulation of left ventricular mass. Nat Genet. 2008;40:546-552

133 Merline R, Schaefer RM, Schaefer L. The matricellular functions of small leucine-rich proteoglycans (slrps). J Cell Commun Signal. 2009;3:323-335

134 Gonzalez R, Urrea R, Gonzalez M, Inestrosa NC, Brandan E. Isolation of proteoglycans synthesized by rat heart: Evidence for the presence of several distinct forms. Gen Pharmacol. 1992;23:249-255

135 Bereczki E, Santha M. The role of biglycan in the heart. Connect Tissue Res. 2008;49:129-132

136 Latif N, Sarathchandra P, Taylor PM, Antoniw J, Yacoub MH. Localization and pattern of expression of extracellular matrix components in human heart valves. J Heart Valve Dis. 2005;14:218-227

137 Ayada Y, Kusachi S, Murakami T, Hirohata S, Takemoto S, Komatsubara I, Hayashi J, Iwabu A, Ninomiya Y, Tsuji T. Increased expression of biglycan mrna in pressure-overloaded rat heart. Clin Exp Hypertens. 2001;23:633-643

138 Ahmed MS, Oie E, Vinge LE, Yndestad A, Andersen GG, Andersson Y, Attramadal T, Attramadal H. Induction of myocardial biglycan in heart failure in rats--an extracellular matrix component targeted by at(1) receptor antagonism. Cardiovasc Res. 2003;60:557-568

139 Medeiros DM, Velleman SG, Jarrold BB, Shiry LJ, Radin MJ, McCune SA. Ontogeny of enhanced decorin levels and distribution within myocardium of failing hearts. Connect Tissue Res. 2002;43:3243

140 Doi M, Kusachi S, Murakami T, Ninomiya Y, Murakami M, Nakahama M, Takeda K, Komatsubara I, 
Naito I, Tsuji T. Time-dependent changes of decorin in the infarct zone after experimentally induced myocardial infarction in rats: Comparison with biglycan. Pathol Res Pract. 2000;196:23-33

141 Zimmerman SD, Thomas DP, Velleman SG, Li X, Hansen TR, McCormick RJ. Time course of collagen and decorin changes in rat cardiac and skeletal muscle post-mi. Am J Physiol Heart Circ Physiol. 2001;281:H1816-1822

142 Hao J, Ju H, Zhao S, Junaid A, Scammell-La Fleur T, Dixon IM. Elevation of expression of smads 2, 3, and 4 , decorin and tgf-beta in the chronic phase of myocardial infarct scar healing. J Mol Cell Cardiol. 1999;31:667-678

143 Westermann D, Mersmann J, Melchior A, Freudenberger T, Petrik C, Schaefer L, Lullmann-Rauch R, Lettau O, Jacoby C, Schrader J, Brand-Herrmann SM, Young MF, Schultheiss HP, Levkau B, Baba HA, Unger T, Zacharowski K, Tschope C, Fischer JW. Biglycan is required for adaptive remodeling after myocardial infarction. Circulation. 2008;117:1269-1276

144 Campbell PH, Hunt DL, Jones Y, Harwood F, Amiel D, Omens JH, McCulloch AD. Effects of biglycan deficiency on myocardial infarct structure and mechanics. Mol Cell Biomech. 2008;5:27-35

145 Bereczki E, Gonda S, Csont T, Korpos E, Zvara A, Ferdinandy P, Santha M. Overexpression of biglycan in the heart of transgenic mice: An antibody microarray study. J Proteome Res. 2007;6:854-861

146 Csont T, Gorbe A, Bereczki E, Szunyog A, Aypar E, Toth ME, Varga ZV, Csonka C, Fulop F, Santha M, Ferdinandy P. Biglycan protects cardiomyocytes against hypoxia/reoxygenation injury: Role of nitric oxide. J Mol Cell Cardiol. 2010;48:649-652

147 Song R, Zeng Q, Ao L, Yu JA, Cleveland JC, Zhao KS, Fullerton DA, Meng X. Biglycan induces the expression of osteogenic factors in human aortic valve interstitial cells via toll-like receptor-2. Arterioscler Thromb Vasc Biol. 2012;32:2711-2720

148 Mersmann J, Habeck K, Latsch K, Zimmermann R, Jacoby C, Fischer JW, Hartmann C, Schrader J, Kirschning CJ, Zacharowski K. Left ventricular dilation in toll-like receptor 2 deficient mice after myocardial ischemia/reperfusion through defective scar formation. Basic Res Cardiol. 2011;106:8998

149 Schaefer L, Babelova A, Kiss E, Hausser HJ, Baliova M, Krzyzankova M, Marsche G, Young MF, Mihalik D, Gotte M, Malle E, Schaefer RM, Grone HJ. The matrix component biglycan is proinflammatory and signals through toll-like receptors 4 and 2 in macrophages. J Clin Invest. 2005;115:2223-2233

150 Babelova A, Moreth K, Tsalastra-Greul W, Zeng-Brouwers J, Eickelberg O, Young MF, Bruckner P, Pfeilschifter J, Schaefer RM, Grone HJ, Schaefer L. Biglycan, a danger signal that activates the nIrp3 inflammasome via toll-like and p2x receptors. J Biol Chem. 2009;284:24035-24048

151 Velleman SG, Ely D. Low score normal muscle weakness alters cardiac decorin expression: Implication for cardiac collagen fibril organization. Poult Sci. 2001;80:1743-1747

152 Jahanyar J, Joyce DL, Southard RE, Loebe M, Noon GP, Koerner MM, Torre-Amione G, Youker KA. Decorin-mediated transforming growth factor-beta inhibition ameliorates adverse cardiac remodeling. J Heart Lung Transplant. 2007;26:34-40

153 Yan W, Wang P, Zhao CX, Tang J, Xiao X, Wang DW. Decorin gene delivery inhibits cardiac fibrosis in spontaneously hypertensive rats by modulation of transforming growth factor-beta/smad and p38 mitogen-activated protein kinase signaling pathways. Hum Gene Ther. 2009;20:1190-1200

154 Pringle GA, Dodd CM. Immunoelectron microscopic localization of the core protein of decorin near the $d$ and e bands of tendon collagen fibrils by use of monoclonal antibodies. J Histochem Cytochem. 1990;38:1405-1411

155 Thieszen SL, Rosenquist TH. Expression of collagens and decorin during aortic arch artery development: Implications for matrix pattern formation. Matrix Biol. 1995;14:573-582

156 Seidler DG. The galactosaminoglycan-containing decorin and its impact on diseases. Curr Opin Struct Biol. 2012;22:578-582

157 Merline R, Moreth K, Beckmann J, Nastase MV, Zeng-Brouwers J, Tralhao JG, Lemarchand P, Pfeilschifter J, Schaefer RM, lozzo RV, Schaefer L. Signaling by the matrix proteoglycan decorin controls inflammation and cancer through pdcd4 and microrna-21. Sci Signal. 2011;4:ra75

158 Ying S, Shiraishi A, Kao CW, Converse RL, Funderburgh JL, Swiergiel J, Roth MR, Conrad GW, Kao WW. Characterization and expression of the mouse lumican gene. J Biol Chem. 1997;272:30306-30313

159 Funderburgh JL. Keratan sulfate: Structure, biosynthesis, and function. Glycobiology. 2000;10:951958

160 Baba H, Ishiwata T, Takashi E, Xu G, Asano G. Expression and localization of lumican in the ischemic and reperfused rat heart. Jpn Circ J. 2001;65:445-450

161 Engebretsen KV, Waehre A, Bjornstad JL, Skrbic B, Sjaastad I, Behmen D, Marstein HS, Yndestad A, Aukrust $P$, Christensen $G$, Tonnessen T. Decorin, lumican, and their gag chain-synthesizing enzymes are regulated in myocardial remodeling and reverse remodeling in the mouse. J Appl Physiol. 
2013;114:988-997

162 Li Y, Aoki T, Mori Y, Ahmad M, Miyamori H, Takino T, Sato H. Cleavage of lumican by membrane-type matrix metalloproteinase-1 abrogates this proteoglycan-mediated suppression of tumor cell colony formation in soft agar. Cancer Res. 2004;64:7058-7064

163 Wu F, Vij N, Roberts L, Lopez-Briones S, Joyce S, Chakravarti S. A novel role of the lumican core protein in bacterial lipopolysaccharide-induced innate immune response. J Biol Chem. 2007;282:2640926417

164 Carlson EC, Lin M, Liu CY, Kao WW, Perez VL, Pearlman E. Keratocan and lumican regulate neutrophil infiltration and corneal clarity in lipopolysaccharide-induced keratitis by direct interaction with cxcl1. J Biol Chem. 2007;282:35502-35509

165 Krishnan A, Li X, Kao WY, Viker K, Butters K, Masuoka H, Knudsen B, Gores G, Charlton M. Lumican, an extracellular matrix proteoglycan, is a novel requisite for hepatic fibrosis. Lab Invest. 2012;92:17121725

166 Hwang JJ, Allen PD, Tseng GC, Lam CW, Fananapazir L, Dzau VJ, Liew CC. Microarray gene expression profiles in dilated and hypertrophic cardiomyopathic end-stage heart failure. Physiol Genomics. 2002;10:31-44

167 Bergquist J, Baykut G, Bergquist M, Witt M, Mayer FJ, Baykut D. Human myocardial protein pattern reveals cardiac diseases. Int J Proteomics. 2012;2012:342659

168 Engebretsen KV, Lunde IG, Strand ME, Waehre A, Sjaastad I, Marstein HS, Skrbic B, DahI CP, Askevold ET, Christensen G, Bjornstad JL, Tonnessen T. Lumican is increased in experimental and clinical heart failure, and its production by cardiac fibroblasts is induced by mechanical and proinflammatory stimuli. Febs J. 2013;280:2382-2398

169 Bornstein P. Diversity of function is inherent in matricellular proteins: An appraisal of thrombospondin 1. J Cell Biol. 1995;130:503-506

170 Bornstein P. Thrombospondins as matricellular modulators of cell function. J Clin Invest. 2001;107:929934

171 Carlson CB, Lawler J, Mosher DF. Structures of thrombospondins. Cell Mol Life Sci. 2008;65:672-686

172 Iruela-Arispe ML, Liska DJ, Sage EH, Bornstein P. Differential expression of thrombospondin 1, 2, and 3 during murine development. Dev Dyn. 1993;197:40-56

173 Arber S, Caroni P. Thrombospondin-4, an extracellular matrix protein expressed in the developing and adult nervous system promotes neurite outgrowth. J Cell Biol. 1995;131:1083-1094

174 Adams JC. Thrombospondins: Multifunctional regulators of cell interactions. Annu Rev Cell Dev Biol. 2001;17:25-51

175 Frangogiannis NG, Ren G, Dewald O, Zymek P, Haudek S, Koerting A, Winkelmann K, Michael LH, Lawler J, Entman ML. Critical role of endogenous thrombospondin-1 in preventing expansion of healing myocardial infarcts. Circulation. 2005;111:2935-2942

176 Schroen B, Heymans S, Sharma U, Blankesteijn WM, Pokharel S, Cleutjens JP, Porter JG, Evelo CT, Duisters R, van Leeuwen RE, Janssen BJ, Debets JJ, Smits JF, Daemen MJ, Crijns HJ, Bornstein P, Pinto YM. Thrombospondin-2 is essential for myocardial matrix integrity: Increased expression identifies failure-prone cardiac hypertrophy. Circ Res. 2004;95:515-522

177 Xia Y, Dobaczewski M, Gonzalez-Quesada C, Chen W, Biernacka A, Li N, Lee DW, Frangogiannis NG. Endogenous thrombospondin 1 protects the pressure-overloaded myocardium by modulating fibroblast phenotype and matrix metabolism. Hypertension. 2011;58:902-911

178 Gonzalez-Quesada C, Cavalera M, Biernacka A, Kong P, Lee DW, Saxena A, Frunza O, Dobaczewski M, Shinde AV, Frangogiannis NG. Thrombospondin-1 induction in the diabetic myocardium stabilizes the cardiac matrix, while promoting vascular rarefaction through angiopoietin-2 upregulation. Circ Res. 2013

179 Swinnen M, Vanhoutte D, Van Almen GC, Hamdani N, Schellings MW, D'Hooge J, Van der Velden J, Weaver MS, Sage EH, Bornstein P, Verheyen FK, VandenDriessche T, Chuah MK, Westermann D, Paulus WJ, Van de Werf F, Schroen B, Carmeliet P, Pinto YM, Heymans S. Absence of thrombospondin-2 causes age-related dilated cardiomyopathy. Circulation. 2009;120:1585-1597

180 Bentley AA, Adams JC. The evolution of thrombospondins and their ligand-binding activities. Mol Biol Evol. 2010;27:2187-2197

181 Murphy-Ullrich JE. The de-adhesive activity of matricellular proteins: Is intermediate cell adhesion an adaptive state? J Clin Invest. 2001;107:785-790

182 Papageorgiou AP, Swinnen M, Vanhoutte D, VandenDriessche T, Chuah M, Lindner D, Verhesen W, de Vries B, D'Hooge J, Lutgens E, Westermann D, Carmeliet P, Heymans S. Thrombospondin-2 prevents cardiac injury and dysfunction in viral myocarditis through the activation of regulatory t-cells. Cardiovasc Res. 2012;94:115-124 
183 Lamy L, Foussat A, Brown EJ, Bornstein P, Ticchioni M, Bernard A. Interactions between cd47 and thrombospondin reduce inflammation. J Immunol. 2007;178:5930-5939

184 Grimbert P, Bouguermouh S, Baba N, Nakajima T, Allakhverdi Z, Braun D, Saito H, Rubio M, Delespesse $\mathrm{G}$, Sarfati M. Thrombospondin/cd47 interaction: A pathway to generate regulatory t cells from human cd4+ cd25- $t$ cells in response to inflammation. J Immunol. 2006;177:3534-3541

185 Savill J, Hogg N, Ren Y, Haslett C. Thrombospondin cooperates with cd36 and the vitronectin receptor in macrophage recognition of neutrophils undergoing apoptosis. J Clin Invest. 1992;90:1513-1522

186 Frolova EG, Sopko N, Blech L, Popovic ZB, Li J, Vasanji A, Drumm C, Krukovets I, Jain MK, Penn MS, Plow EF, Stenina OI. Thrombospondin-4 regulates fibrosis and remodeling of the myocardium in response to pressure overload. Faseb J. 2012;26:2363-2373

187 Lynch JM, Maillet M, Vanhoutte D, Schloemer A, Sargent MA, Blair NS, Lynch KA, Okada T, Aronow BJ, Osinska H, Prywes R, Lorenz JN, Mori K, Lawler J, Robbins J, Molkentin JD. A thrombospondindependent pathway for a protective er stress response. Cell. 2012;149:1257-1268

188 Tan FL, Moravec CS, Li J, Apperson-Hansen C, McCarthy PM, Young JB, Bond M. The gene expression fingerprint of human heart failure. Proc Natl Acad Sci U S A. 2002;99:11387-11392

189 Stenina OI, Topol EJ, Plow EF. Thrombospondins, their polymorphisms, and cardiovascular disease. Arterioscler Thromb Vasc Biol. 2007;27:1886-1894

190 Termine JD, Kleinman HK, Whitson SW, Conn KM, McGarvey ML, Martin GR. Osteonectin, a bonespecific protein linking mineral to collagen. Cell. 1981;26:99-105

191 Brekken RA, Sage EH. Sparc, a matricellular protein: At the crossroads of cell-matrix communication. Matrix Biol. 2001;19:816-827

192 Schellings MW, Vanhoutte D, Swinnen M, Cleutjens JP, Debets J, van Leeuwen RE, d'Hooge J, Van de Werf F, Carmeliet P, Pinto YM, Sage EH, Heymans S. Absence of sparc results in increased cardiac rupture and dysfunction after acute myocardial infarction. J Exp Med. 2009;206:113-123

193 Bradshaw AD, Baicu CF, Rentz TJ, Van Laer AO, Boggs J, Lacy JM, Zile MR. Pressure overload-induced alterations in fibrillar collagen content and myocardial diastolic function: Role of secreted protein acidic and rich in cysteine (sparc) in post-synthetic procollagen processing. Circulation. 2009;119:269280

194 Bradshaw AD, Baicu CF, Rentz TJ, Van Laer AO, Bonnema DD, Zile MR. Age-dependent alterations in fibrillar collagen content and myocardial diastolic function: Role of sparc in post-synthetic procollagen processing. Am J Physiol Heart Circ Physiol. 2010;298:H614-622

195 Komatsubara I, Murakami T, Kusachi S, Nakamura K, Hirohata S, Hayashi J, Takemoto S, Suezawa C, Ninomiya Y, Shiratori Y. Spatially and temporally different expression of osteonectin and osteopontin in the infarct zone of experimentally induced myocardial infarction in rats. Cardiovasc Pathol. 2003;12:186-194

196 Maurer P, Gohring W, Sasaki T, Mann K, Timpl R, Nischt R. Recombinant and tissue-derived mouse $\mathrm{bm}-40$ bind to several collagen types and have increased affinities after proteolytic activation. Cell Mol Life Sci. 1997;53:478-484

197 Sasaki T, Gohring W, Mann K, Maurer P, Hohenester E, Knauper V, Murphy G, Timpl R. Limited cleavage of extracellular matrix protein bm-40 by matrix metalloproteinases increases its affinity for collagens. J Biol Chem. 1997;272:9237-9243

198 Sage EH, Reed M, Funk SE, Truong T, Steadele M, Puolakkainen P, Maurice DH, Bassuk JA. Cleavage of the matricellular protein sparc by matrix metalloproteinase 3 produces polypeptides that influence angiogenesis. J Biol Chem. 2003;278:37849-37857

199 Chen G, Tian X, Liu Z, Zhou S, Schmidt B, Henne-Bruns D, Bachem M, Kornmann M. Inhibition of endogenous sparc enhances pancreatic cancer cell growth: Modulation by fgfr1-iii isoform expression. Br J Cancer. 2010;102:188-195

200 Kupprion C, Motamed K, Sage EH. Sparc (bm-40, osteonectin) inhibits the mitogenic effect of vascular endothelial growth factor on microvascular endothelial cells. J Biol Chem. 1998;273:29635-29640

201 Motamed K, Funk SE, Koyama H, Ross R, Raines EW, Sage EH. Inhibition of pdgf-stimulated and matrix-mediated proliferation of human vascular smooth muscle cells by sparc is independent of changes in cell shape or cyclin-dependent kinase inhibitors. J Cell Biochem. 2002;84:759-771

202 Francki A, Motamed K, McClure TD, Kaya M, Murri C, Blake DJ, Carbon JG, Sage EH. Sparc regulates cell cycle progression in mesangial cells via its inhibition of igf-dependent signaling. J Cell Biochem. 2003;88:802-811

203 Francki A, McClure TD, Brekken RA, Motamed K, Murri C, Wang T, Sage EH. Sparc regulates tgf-beta1dependent signaling in primary glomerular mesangial cells. J Cell Biochem. 2004;91:915-925

204 Francki A, Bradshaw AD, Bassuk JA, Howe CC, Couser WG, Sage EH. Sparc regulates the expression of collagen type $i$ and transforming growth factor-beta1 in mesangial cells. J Biol Chem. 1999;274:32145- 
32152

205 Chiquet-Ehrismann R, Chiquet M. Tenascins: Regulation and putative functions during pathological stress. J Pathol. 2003;200:488-499

206 Niebroj-Dobosz I. Tenascin-c in human cardiac pathology. Clin Chim Acta. 2012;413:1516-1518

207 Hsia HC, Schwarzbauer JE. Meet the tenascins: Multifunctional and mysterious. J Biol Chem. 2005;280:26641-26644

208 Jones FS, Jones PL. The tenascin family of ecm glycoproteins: Structure, function, and regulation during embryonic development and tissue remodeling. Dev Dyn. 2000;218:235-259

209 Chiquet-Ehrismann R, Tannheimer M, Koch M, Brunner A, Spring J, Martin D, Baumgartner S, Chiquet M. Tenascin-c expression by fibroblasts is elevated in stressed collagen gels. J Cell Biol. 1994;127:20932101

210 Clark RA, Erickson HP, Springer TA. Tenascin supports lymphocyte rolling. J Cell Biol. 1997;137:755765

211 Loike JD, Cao L, Budhu S, Hoffman S, Silverstein SC. Blockade of alpha 5 beta 1 integrins reverses the inhibitory effect of tenascin on chemotaxis of human monocytes and polymorphonuclear leukocytes through three-dimensional gels of extracellular matrix proteins. J Immunol. 2001;166:7534-7542

212 Midwood K, Sacre S, Piccinini AM, Inglis J, Trebaul A, Chan E, Drexler S, Sofat N, Kashiwagi M, Orend $\mathrm{G}$, Brennan F, Foxwell B. Tenascin-c is an endogenous activator of toll-like receptor 4 that is essential for maintaining inflammation in arthritic joint disease. Nat Med. 2009;15:774-780

213 Nishioka T, Onishi K, Shimojo N, Nagano Y, Matsusaka H, Ikeuchi M, Ide T, Tsutsui H, Hiroe M, Yoshida T, Imanaka-Yoshida K. Tenascin-c may aggravate left ventricular remodeling and function after myocardial infarction in mice. Am J Physiol Heart Circ Physiol. 2010;298:H1072-1078

214 Chiquet-Ehrismann R, Kalla P, Pearson CA, Beck K, Chiquet M. Tenascin interferes with fibronectin action. Cell. 1988;53:383-390

215 Chiquet-Ehrismann R, Matsuoka Y, Hofer U, Spring J, Bernasconi C, Chiquet M. Tenascin variants: Differential binding to fibronectin and distinct distribution in cell cultures and tissues. Cell Regul. 1991;2:927-938

216 Imanaka-Yoshida K, Hiroe M, Nishikawa T, Ishiyama S, Shimojo T, Ohta Y, Sakakura T, Yoshida T. Tenascin-c modulates adhesion of cardiomyocytes to extracellular matrix during tissue remodeling after myocardial infarction. Lab Invest. 2001;81:1015-1024

217 Xia Y, Lee K, Li N, Corbett D, Mendoza L, Frangogiannis NG. Characterization of the inflammatory and fibrotic response in a mouse model of cardiac pressure overload. Histochem Cell Biol. 2009;131:471481

218 Imanaka-Yoshida K, Hiroe M, Yasutomi Y, Toyozaki T, Tsuchiya T, Noda N, Maki T, Nishikawa T, Sakakura T, Yoshida T. Tenascin-c is a useful marker for disease activity in myocarditis. J Pathol. 2002;197:388394

219 Liabeuf S, Barreto DV, Kretschmer A, Barreto FC, Renard C, Andrejak M, Choukroun G, Massy Z. High circulating levels of large splice variants of tenascin-c is associated with mortality and cardiovascular disease in chronic kidney disease patients. Atherosclerosis. 2011;215:116-124

220 Yao HC, Han QF, Zhao AP, Yao DK, Wang LX. Prognostic values of serum tenascin-c in patients with ischaemic heart disease and heart failure. Heart Lung Circ. 2013;22:184-187

221 Sarli B, Topsakal R, Kaya EG, Akpek M, Lam YY, Kaya MG. Tenascin-c as predictor of left ventricular remodeling and mortality in patients with dilated cardiomyopathy. J Investig Med. 2013;61:728-732

222 Sato A, Hiroe M, Akiyama D, Hikita H, Nozato T, Hoshi T, Kimura T, Wang Z, Sakai S, Imanaka-Yoshida K, Yoshida T, Aonuma K. Prognostic value of serum tenascin-c levels on long-term outcome after acute myocardial infarction. J Card Fail. 2012;18:480-486

223 Franzen A, Heinegard D. Isolation and characterization of two sialoproteins present only in bone calcified matrix. Biochem J. 1985;232:715-724

224 Wang KX, Denhardt DT. Osteopontin: Role in immune regulation and stress responses. Cytokine Growth Factor Rev. 2008;19:333-345

225 Waller AH, Sanchez-Ross M, Kaluski E, Klapholz M. Osteopontin in cardiovascular disease: A potential therapeutic target. Cardiol Rev. 2010;18:125-131

226 Ito K, Kon S, Nakayama Y, Kurotaki D, Saito Y, Kanayama M, Kimura C, Diao H, Morimoto J, Matsui Y, Uede T. The differential amino acid requirement within osteopontin in alpha4 and alpha9 integrinmediated cell binding and migration. Matrix Biol. 2009;28:11-19

227 Singh K, Sirokman G, Communal C, Robinson KG, Conrad CH, Brooks WW, Bing OH, Colucci WS. Myocardial osteopontin expression coincides with the development of heart failure. Hypertension. 1999;33:663-670

228 Matsui Y, Jia N, Okamoto H, Kon S, Onozuka H, Akino M, Liu L, Morimoto J, Rittling SR, Denhardt D, 
Kitabatake A, Uede T. Role of osteopontin in cardiac fibrosis and remodeling in angiotensin ii-induced cardiac hypertrophy. Hypertension. 2004;43:1195-1201

229 Xie Z, Singh M, Singh K. Osteopontin modulates myocardial hypertrophy in response to chronic pressure overload in mice. Hypertension. 2004;44:826-831

230 Collins AR, Schnee J, Wang W, Kim S, Fishbein MC, Bruemmer D, Law RE, Nicholas S, Ross RS, Hsueh WA. Osteopontin modulates angiotensin ii-induced fibrosis in the intact murine heart. J Am Coll Cardiol. 2004;43:1698-1705

231 Trueblood NA, Xie Z, Communal C, Sam F, Ngoy S, Liaw L, Jenkins AW, Wang J, Sawyer DB, Bing OH, Apstein CS, Colucci WS, Singh K. Exaggerated left ventricular dilation and reduced collagen deposition after myocardial infarction in mice lacking osteopontin. Circ Res. 2001;88:1080-1087

232 Miller SJ, Watson WC, Kerr KA, Labarrere CA, Chen NX, Deeg MA, Unthank JL. Development of progressive aortic vasculopathy in a rat model of aging. Am J Physiol Heart Circ Physiol. 2007;293:H2634-2643

233 O’Brien KD, Kuusisto J, Reichenbach DD, Ferguson M, Giachelli C, Alpers CE, Otto CM. Osteopontin is expressed in human aortic valvular lesions. Circulation. 1995;92:2163-2168

234 Mazzali M, Kipari T, Ophascharoensuk V, Wesson JA, Johnson R, Hughes J. Osteopontin--a molecule for all seasons. Qjm. 2002;95:3-13

235 O’Regan AW, Chupp GL, Lowry JA, Goetschkes M, Mulligan N, Berman JS. Osteopontin is associated with $t$ cells in sarcoid granulomas and has $t$ cell adhesive and cytokine-like properties in vitro. J Immunol. 1999;162:1024-1031

236 Murry CE, Giachelli CM, Schwartz SM, Vracko R. Macrophages express osteopontin during repair of myocardial necrosis. Am J Pathol. 1994;145:1450-1462

237 Schipper ME, Scheenstra MR, van Kuik J, van Wichen DF, van der Weide P, Dullens HF, Lahpor J, de Jonge N, De Weger RA. Osteopontin: A potential biomarker for heart failure and reverse remodeling after left ventricular assist device support. J Heart Lung Transplant. 2011;30:805-810

238 Suezawa C, Kusachi S, Murakami T, Toeda K, Hirohata S, Nakamura K, Yamamoto K, Koten K, Miyoshi T, Shiratori Y. Time-dependent changes in plasma osteopontin levels in patients with anterior-wall acute myocardial infarction after successful reperfusion: Correlation with left-ventricular volume and function. J Lab Clin Med. 2005;145:33-40

239 Sainger R, Grau JB, Poggio P, Branchetti E, Bavaria JE, Gorman JH, 3rd, Gorman RC, Ferrari G. Dephosphorylation of circulating human osteopontin correlates with severe valvular calcification in patients with calcific aortic valve disease. Biomarkers. 2012;17:111-118

240 Grau JB, Poggio P, Sainger R, Vernick WJ, Seefried WF, Branchetti E, Field BC, Bavaria JE, Acker MA, Ferrari G. Analysis of osteopontin levels for the identification of asymptomatic patients with calcific aortic valve disease. Ann Thorac Surg. 2012;93:79-86

241 Yu PJ, Skolnick A, Ferrari G, Heretis K, Mignatti P, Pintucci G, Rosenzweig B, Diaz-Cartelle J, Kronzon I, Perk G, Pass HI, Galloway AC, Grossi EA, Grau JB. Correlation between plasma osteopontin levels and aortic valve calcification: Potential insights into the pathogenesis of aortic valve calcification and stenosis. J Thorac Cardiovasc Surg. 2009;138:196-199

242 Niebroj-Dobosz I, Madej-Pilarczyk A, Marchel M, Sokolowska B, Hausmanowa-Petrusewicz I. Osteopontin--a fibrosis-related marker--in dilated cardiomyopathy in patients with emery-dreifuss muscular dystrophy. Scand J Clin Lab Invest. 2011;71:658-662

243 Rosenberg M, Zugck C, Nelles M, Juenger C, Frank D, Remppis A, Giannitsis E, Katus HA, Frey N. Osteopontin, a new prognostic biomarker in patients with chronic heart failure. Circ Heart Fail. 2008;1:43-49

244 Horiuchi K, Amizuka N, Takeshita S, Takamatsu H, Katsuura M, Ozawa H, Toyama Y, Bonewald LF, Kudo A. Identification and characterization of a novel protein, periostin, with restricted expression to periosteum and periodontal ligament and increased expression by transforming growth factor beta. J Bone Miner Res. 1999;14:1239-1249

245 Elkins T, Hortsch M, Bieber AJ, Snow PM, Goodman CS. Drosophila fasciclin i is a novel homophilic adhesion molecule that along with fasciclin iii can mediate cell sorting. J Cell Biol. 1990;110:18251832

246 Braun N, Sen K, Alscher MD, Fritz P, Kimmel M, Morelle J, Goffin E, Jorres A, Wuethrich RP, Cohen CD, Segerer S. Periostin: A matricellular protein involved in peritoneal injury during peritoneal dialysis. Perit Dial Int. 2013

247 Sen K, Lindenmeyer MT, Gaspert A, Eichinger F, Neusser MA, Kretzler M, Segerer S, Cohen CD. Periostin is induced in glomerular injury and expressed de novo in interstitial renal fibrosis. Am J Pathol. 2011;179:1756-1767

248 Lindner V, Wang Q, Conley BA, Friesel RE, Vary CP. Vascular injury induces expression of periostin: 
Implications for vascular cell differentiation and migration. Arterioscler Thromb Vasc Biol. 2005;25:7783

249 Norris RA, Damon B, Mironov V, Kasyanov V, Ramamurthi A, Moreno-Rodriguez R, Trusk T, Potts JD, Goodwin RL, Davis J, Hoffman S, Wen X, Sugi Y, Kern CB, Mjaatvedt CH, Turner DK, Oka T, Conway SJ, Molkentin JD, Forgacs G, Markwald RR. Periostin regulates collagen fibrillogenesis and the biomechanical properties of connective tissues. J Cell Biochem. 2007;101:695-711

250 Shimazaki M, Nakamura K, Kii I, Kashima T, Amizuka N, Li M, Saito M, Fukuda K, Nishiyama T, Kitajima S, Saga Y, Fukayama M, Sata M, Kudo A. Periostin is essential for cardiac healing after acute myocardial infarction. J Exp Med. 2008;205:295-303

251 Stansfield WE, Andersen NM, Tang RH, Selzman $\mathrm{CH}$. Periostin is a novel factor in cardiac remodeling after experimental and clinical unloading of the failing heart. Ann Thorac Surg. 2009;88:1916-1921

252 Hakuno D, Kimura N, Yoshioka M, Mukai M, Kimura T, Okada Y, Yozu R, Shukunami C, Hiraki Y, Kudo A, Ogawa S, Fukuda K. Periostin advances atherosclerotic and rheumatic cardiac valve degeneration by inducing angiogenesis and mmp production in humans and rodents. J Clin Invest. 2010;120:22922306

253 Oka T, Xu J, Kaiser RA, Melendez J, Hambleton M, Sargent MA, Lorts A, Brunskill EW, Dorn GW, 2nd, Conway SJ, Aronow BJ, Robbins J, Molkentin JD. Genetic manipulation of periostin expression reveals a role in cardiac hypertrophy and ventricular remodeling. Circ Res. 2007;101:313-321

254 Stanton LW, Garrard LJ, Damm D, Garrick BL, Lam A, Kapoun AM, Zheng Q, Protter AA, Schreiner GF, White RT. Altered patterns of gene expression in response to myocardial infarction. Circ Res. 2000;86:939-945

255 Ladage D, Yaniz-Galende E, Rapti K, Ishikawa K, Tilemann L, Shapiro S, Takewa Y, Muller-Ehmsen J, Schwarz M, Garcia MJ, Sanz J, Hajjar RJ, Kawase Y. Stimulating myocardial regeneration with periostin peptide in large mammals improves function post-myocardial infarction but increases myocardial fibrosis. PLoS One. 2013;8:e59656

256 Bork P. The modular architecture of a new family of growth regulators related to connective tissue growth factor. FEBS Lett. 1993;327:125-130

257 Mosher DF, Adams JC. Adhesion-modulating/matricellular ecm protein families: A structural, functional and evolutionary appraisal. Matrix Biol. 2012;31:155-161

258 Ohnishi H, Oka T, Kusachi S, Nakanishi T, Takeda K, Nakahama M, Doi M, Murakami T, Ninomiya Y, Takigawa M, Tsuji T. Increased expression of connective tissue growth factor in the infarct zone of experimentally induced myocardial infarction in rats. J Mol Cell Cardiol. 1998;30:2411-2422

259 Finckenberg P, Inkinen K, Ahonen J, Merasto S, Louhelainen M, Vapaatalo H, Muller D, Ganten D, Luft $\mathrm{F}$, Mervaala $\mathrm{E}$. Angiotensin ii induces connective tissue growth factor gene expression via calcineurindependent pathways. Am J Pathol. 2003;163:355-366

260 Iwamoto M, Hirohata S, Ogawa H, Ohtsuki T, Shinohata R, Miyoshi T, Hatipoglu FO, Kusachi S, Yamamoto K, Ninomiya Y. Connective tissue growth factor induction in a pressure-overloaded heart ameliorated by the angiotensin ii type 1 receptor blocker olmesartan. Hypertens Res. 2010;33:13051311

261 Way KJ, Isshiki K, Suzuma K, Yokota T, Zvagelsky D, Schoen FJ, Sandusky GE, Pechous PA, Vlahos CJ, Wakasaki H, King GL. Expression of connective tissue growth factor is increased in injured myocardium associated with protein kinase c beta2 activation and diabetes. Diabetes. 2002;51:2709-2718

262 Ahmed MS, Gravning J, Martinov VN, von Lueder TG, Edvardsen T, Czibik G, Moe IT, Vinge LE, Oie E, Valen G, Attramadal H. Mechanisms of novel cardioprotective functions of ccn2/ctgf in myocardial ischemia-reperfusion injury. Am J Physiol Heart Circ Physiol. 2011;300:H1291-1302

263 Chen MM, Lam A, Abraham JA, Schreiner GF, Joly AH. Ctgf expression is induced by tgf- beta in cardiac fibroblasts and cardiac myocytes: A potential role in heart fibrosis. J Mol Cell Cardiol. 2000;32:18051819

264 Dean RG, Balding LC, Candido R, Burns WC, Cao Z, Twigg SM, Burrell LM. Connective tissue growth factor and cardiac fibrosis after myocardial infarction. J Histochem Cytochem. 2005;53:1245-1256

265 Ahmed MS, von Lueder TG, Oie E, Kjekshus H, Attramadal H. Induction of myocardial connective tissue growth factor in pacing-induced heart failure in pigs. Acta Physiol Scand. 2005;184:27-36

266 Booth AJ, Csencsits-Smith K, Wood SC, Lu G, Lipson KE, Bishop DK. Connective tissue growth factor promotes fibrosis downstream of tgfbeta and il- 6 in chronic cardiac allograft rejection. Am J Transplant. 2010;10:220-230

267 Panek AN, Posch MG, Alenina N, Ghadge SK, Erdmann B, Popova E, Perrot A, Geier C, Dietz R, Morano I, Bader M, Ozcelik C. Connective tissue growth factor overexpression in cardiomyocytes promotes cardiac hypertrophy and protection against pressure overload. PLoS One. 2009;4:e6743

268 Yoon PO, Lee MA, Cha H, Jeong MH, Kim J, Jang SP, Choi BY, Jeong D, Yang DK, Hajjar RJ, Park WJ. The 
opposing effects of ccn2 and ccn5 on the development of cardiac hypertrophy and fibrosis. J Mol Cell Cardiol. 2010;49:294-303

269 Ahmed MS, Oie E, Vinge LE, Yndestad A, Oystein Andersen G, Andersson Y, Attramadal T, Attramadal $\mathrm{H}$. Connective tissue growth factor--a novel mediator of angiotensin ii-stimulated cardiac fibroblast activation in heart failure in rats. J Mol Cell Cardiol. 2004;36:393-404

270 Hilfiker-Kleiner D, Kaminski K, Kaminska A, Fuchs M, Klein G, Podewski E, Grote K, Kiian I, Wollert KC, Hilfiker A, Drexler H. Regulation of proangiogenic factor ccn1 in cardiac muscle: Impact of ischemia, pressure overload, and neurohumoral activation. Circulation. 2004;109:2227-2233

271 Yoshida Y, Togi K, Matsumae H, Nakashima Y, Kojima Y, Yamamoto H, Ono K, Nakamura T, Kita T, Tanaka M. Ccn1 protects cardiac myocytes from oxidative stress via beta1 integrin-akt pathway. Biochem Biophys Res Commun. 2007;355:611-618

272 Rother M, Krohn S, Kania G, Vanhoutte D, Eisenreich A, Wang X, Westermann D, Savvatis K, Dannemann N, Skurk C, Hilfiker-Kleiner D, Cathomen T, Fechner H, Rauch U, Schultheiss HP, Heymans S, Eriksson U, Scheibenbogen C, Poller W. Matricellular signaling molecule ccn1 attenuates experimental autoimmune myocarditis by acting as a novel immune cell migration modulator. Circulation. 2010;122:2688-2698

273 Wittchen F, Suckau L, Witt H, Skurk C, Lassner D, Fechner H, Sipo I, Ungethum U, Ruiz P, Pauschinger M, Tschope C, Rauch U, Kuhl U, Schultheiss HP, Poller W. Genomic expression profiling of human inflammatory cardiomyopathy (dcmi) suggests novel therapeutic targets. J Mol Med (Berl). 2007;85:257-271

274 Colston JT, de la Rosa SD, Koehler M, Gonzales K, Mestril R, Freeman GL, Bailey SR, Chandrasekar B. Wnt-induced secreted protein-1 is a prohypertrophic and profibrotic growth factor. Am J Physiol Heart Circ Physiol. 2007;293:H1839-1846

275 Venkatesan B, Prabhu SD, Venkatachalam K, Mummidi S, Valente AJ, Clark RA, Delafontaine P, Chandrasekar B. Wnt1-inducible signaling pathway protein-1 activates diverse cell survival pathways and blocks doxorubicin-induced cardiomyocyte death. Cell Signal. 2010;22:809-820

276 Venkatachalam K, Venkatesan B, Valente AJ, Melby PC, Nandish S, Reusch JE, Clark RA, Chandrasekar B. Wisp1, a pro-mitogenic, pro-survival factor, mediates tumor necrosis factor-alpha (tnf-alpha)stimulated cardiac fibroblast proliferation but inhibits tnf-alpha-induced cardiomyocyte death. J Biol Chem. 2009;284:14414-14427

277 Taylor KR, Gallo RL. Glycosaminoglycans and their proteoglycans: Host-associated molecular patterns for initiation and modulation of inflammation. Faseb J. 2006;20:9-22

278 Ylisastigui L, Bakri Y, Amzazi S, Gluckman JC, Benjouad A. Soluble glycosaminoglycans do not potentiate rantes antiviral activity on the infection of primary macrophages by human immunodeficiency virus type 1 . Virology. 2000;278:412-422

279 Venkataswarup Tiriveedhi PB. Soluble glycosaminoglycans inhibit the interaction of tat-ptd with lipid vesicles. International Journal of Peptide Research and Therapeutics. 2008;14:209-214

280 Linhardt RJ. Analysis of glycosaminoglycans with polysaccharide lyases. Curr Protoc Mol Biol. 2001; Chapter 17:Unit17 13B

281 Morelle W, Michalski JC. Analysis of protein glycosylation by mass spectrometry. Nat Protoc. 2007;2:1585-1602 

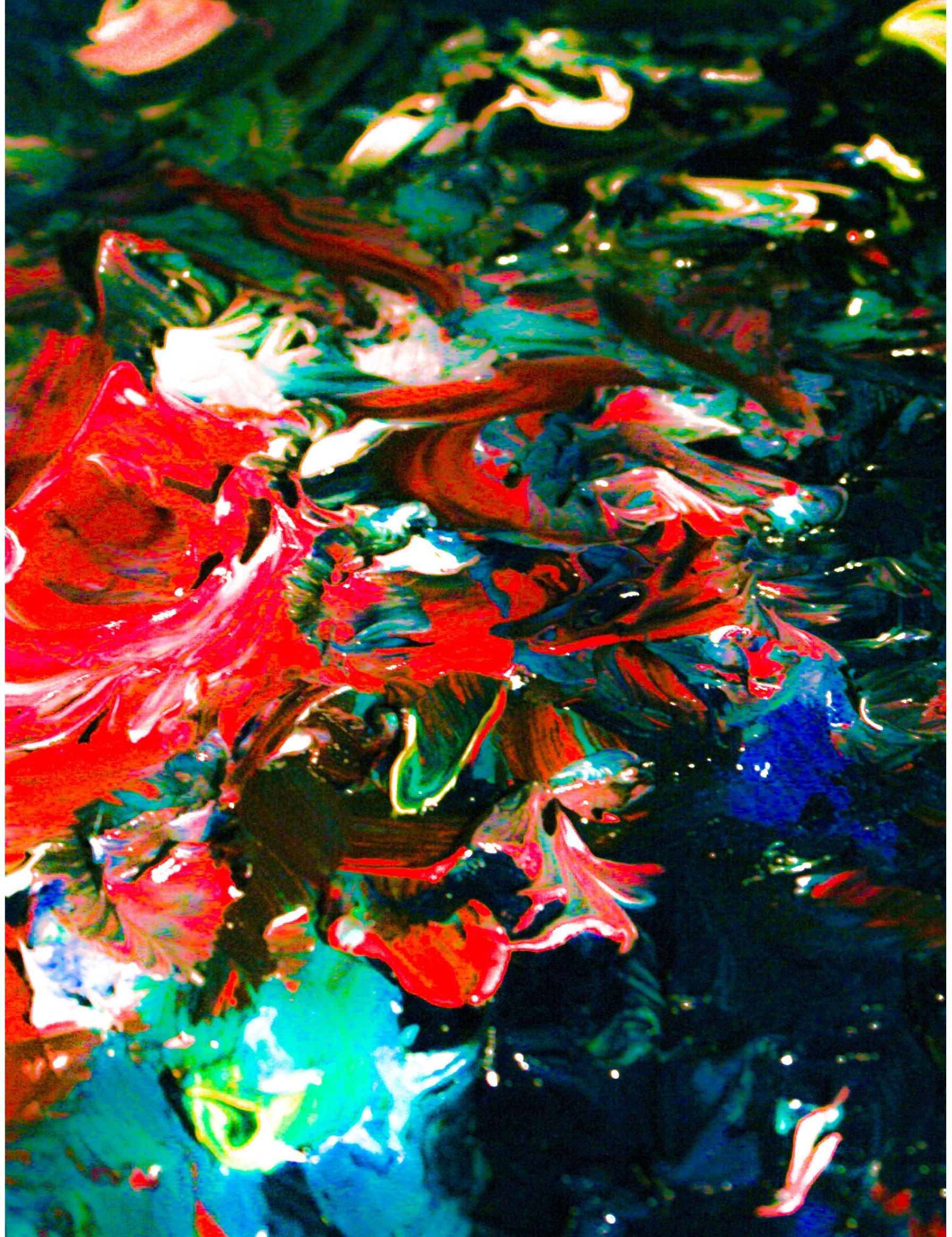


\section{Abstract}

Background: Viral myocarditis can severely damage the myocardium through excessive infiltration of immune cells. Osteoglycin (OGN) is a small leucine-rich repeat proteoglycan (SLRP) involved in cardiac fibrosis after myocardial infarction. Whether this SLRP may also affect cardiac inflammation and the resulting injury in myocarditis is unknown.

Methods and Results: This study uncovered a previously unidentified $72-\mathrm{kDa}$ variant of OGN that is predominant in viral myocarditis. Enzymatic assays revealed that the $32-\mathrm{kDa}$ protein core of OGN can be post-translationally modified by O-linked glycosylation to the $72-\mathrm{kDa}$ chondroitin sulfate OGN, and the $34-\mathrm{kDa}$ dermatan sulfate OGN. The $72-\mathrm{kDa}$ OGN is expressed in the cell membrane of circulating and resident cardiac macrophages and neutrophils in both human and murine cells. Co-immunoprecipitation and OGN siRNA experiments reveal that this $72-\mathrm{kDa}$ variant binds and activates toll-like receptor-4 (TLR4) with a concomitant increase in IL-6, TNF- $\alpha$, IL-1 $\beta$ and IL-12 expression. Accordingly, absence of OGN in knockout mice significantly decreased cardiac inflammation in CVB3induced myocarditis and delayed mortality in lipopolysaccharide-induced endotoxemia with the reduced production of pro-inflammatory cytokines. Finally, fluorescence activated cell sorting analysis in human OGN-positive circulating neutrophils revealed the enhanced phosphorylation of c jun, emphasizing the importance of OGN in innate immune activation.

Conclusion: The current study discovered a novel 72-kDa chondroitin sulfate OGN that is specific for innate immune cells. This variant is able to bind and activate TLR4. The absence of OGN therefore decreases the cytokine response upon LPS injection and reduces cardiac inflammation and injury in viral myocarditis. 


\section{INTRODUCTION}

Osteoglycin (OGN) belongs to the small leucine-rich proteoglycan (SLRP) family of proteins, which also includes biglycan and decorin. These SLRPs are well known for their welltimed action on shaping the architecture and organization of collagen-rich extracellular matrices in the heart and other organs ${ }^{1}$. We have recently demonstrated that OGN is critical during the wound healing process after myocardial infarction by stimulating the formation of well-aligned collagen fibers in the infarct scar ${ }^{2}$. Some matrix components, proteoglycans and glycoproteins, have been recognized for regulating inflammation in organs outside the heart ${ }^{3}$; however, no such role has been described for OGN in either the heart or other organs. Furthermore, OGN is a proteoglycan and is therefore subject to glycosylation, a post-translation modification that adds glycosaminoglycans and glycans to proteins in the endoplasmic reticulum and Golgi apparatus, diversifying protein function. While OGN requires glycosaminoglycan keratan sulfate for corneal transparency ${ }^{4,5}$, no clear-cut and comprehensive description of all potential glycosylation variants is available. Moreover, nothing is known about its glycosylation state during heart failure or the impact that this may have on its immune modulatory function.

Cardiac inflammation with consecutive adverse remodeling as a consequence of cardiac damage is an important cause of heart failure and sudden cardiac death in previously healthy, young individuals ${ }^{6}$. Understanding how the immune system responds to various endangering stimuli (ischemia versus viruses) might clarify the contribution of the inflammatory response to adverse cardiac remodeling and hence lead to the discovery of specific therapeutic strategies. The need for new specific therapeutic strategies is underlined by the poor prognosis once heart failure becomes chronic ${ }^{7}$.

Here, we discovered that SLRP OGN is differentially glycosylated in myocarditis relative to myocardial infarction. Whereas the OGN-dermatan sulfate $(34 \mathrm{kDa})$ is linked to cardiac fibrosis, the previously unknown OGN-chondroitin sulfate $(72 \mathrm{kDa})$ predominates in the cell membrane of both murine and human leukocytes. This $72-\mathrm{kDa}$ inflammatory variant binds to TLR4 and enhances its activation. As such, increased OGN results in exaggerated innate immune responses in endotoxemia and viral myocarditis.

\section{Material and Methods}

\section{Animals}

C57Bl6/J male and female OGN-KO mice (backcrossed more than 15 times) and WT mice in the same background between 8 and 12 weeks of age were used in this study, and all experiments were performed using age and sex-matched groups. Mice were maintained in specific pathogen-free facilities at Leuven University. All of the study protocols were approved by the Animal Care and Use Committee of the University of Leuven 243/2013. Experiments were performed according to the official rules formulated in the Belgian law on the care and use of experimental animals.

\section{Murine CVB3-induced Viral Myocarditis Model}

Eight to twelve week old OGN-KO and WT mice were inoculated by intraperitoneal (ip) injection of $1 \times 107$ cells with a 50\% infective dose (CCID50) of CVB3 (Nancy Strain) diluted in $0.2 \mathrm{~mL}$ of saline on day 0 . All animals were anaesthetized with an ip injection of 
Xylazine $(10 \mathrm{mg} / \mathrm{kg})$ and Ketamine $(100 \mathrm{mg} / \mathrm{kg})$ and sacrificed by cervical dislocation 2,4 or 7 days after CVB3 infection. Organs were excised for further molecular and histological analyses.

\section{Endotoxic Shock model and Cytokine Measurements}

Age and sex matched OGN WT and KO mice between 6 and 12 weeks of age were given an ip injection of $40 \mathrm{mg}$ of D-galactosamine $(200 \mu \mathrm{l})$ followed by an intravenous injection of LPS (E. coli Ultrapure O111:B4, InvivoGen) after 15 minutes. One hour later, whole blood was taken via eye puncture, after which survival was monitored every hour. After allowing the blood to clot by leaving it undisturbed at room temperature for approximately 30 minutes, the clot was removed by centrifuging at 1.000-2.000 g for 10 minutes in a refrigerated centrifuge. Serum was stored at $-20^{\circ} \mathrm{C}$ prior to cytokine measurements. Cytokines were measured in serum and medium from in vitro macrophage experiments using V-PLEX Proinflammatory Panel1 (mouse) Kit (K15048D-1) according to the manufacturer's protocol.

\section{STAINING AND IMMUNOHISTOCHEMISTRY}

Hearts were perfused from the apex with PBS, fixed overnight in zinc fixative (BD Pharmingen, 550523) and processed the following day prior to being embedded in paraffin. The paraffin embedded left ventricle was cut longitudinally in $4-\mu \mathrm{m}$ sections and stained with hematoxylin and eosin (necrosis/ inflammation) or Sirius red F3BA (fibrosis).

Immunohistochemistry on zinc-fixed paraffin sections was performed without using antigen retrieval according to a protocol using antibodies against CD45 (BD Pharmingen; 1:200), Mac3 (Serotec MCAP497; 1:100), CD3 (Thermo Scientific; 1:200), TLR4 (Abcam, ab22048) and OGN (for human slides, Sigma HPA013132, 1:200; for murine slides, US Biological O8062-05A, 1:100). Images were acquired using Leica Qwin image processing software (Leica, Germany).

\section{Western Wlotting and EnZyme Treatments}

Tissues were lysed in RIPA SDS (50 mM Tris- $\mathrm{HCl}, 150 \mathrm{mM} \mathrm{NaCl}, 0.1 \%$ SDS, $0.5 \%$ sodium deoxycholate, 1\% NP40, Proteinase Inhibitor Cocktail, Roche, 11697498001 and $0.5 \mathrm{mM}$ orthovanadate), after which the protein concentration was determined using a Micro BCA Protein assay kit (Thermo Scientific, Lot MJ162220). Samples were diluted to a final concentration of $2 \mu \mathrm{g} / \mathrm{ul}$, after which two times sample buffer $(25 \mathrm{ml} 0.5 \mathrm{M}$ Tris- $\mathrm{HCl}$,

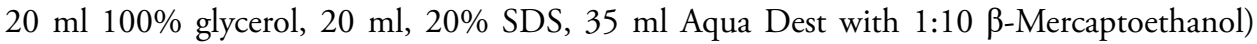
was added to protein samples at a 1:1 ratio. Cells were directly lysed in sample buffer. For western blot analyses, $20 \mu \mathrm{g}$ of protein was loaded on a $10 \%$ gel ( $4 \mathrm{ml}$ Aqua Dest, $3.3 \mathrm{ml}$ $30 \%$ bisacrylamide, $2.5 \mathrm{ml} \mathrm{1.5} \mathrm{M} \mathrm{Tris-} \mathrm{HCl}, \mathrm{pH} 8.8,0.1 \mathrm{ml} \mathrm{10 \%} \mathrm{SDS,} 0.004 \mathrm{ml}$ TEMED). SDS PAGE was performed at $150 \mathrm{~V}$ for approximately 90 minutes, after which the gel was transferred to a PVDF membrane by blotting at $200 \mathrm{~mA}$ for $2 \mathrm{~h}$. The membranes were blocked with 3.5\% protifar (Nutricia) for $1 \mathrm{~h}$. Primary antibody was incubated overnight in 5\% BSA for osteoglycin (R\&D, MAB2949), MyD88 (CTS, \#4283S), (p)ERK1/2 (CTS, \#9101S and \#4695P), (p)JNK (CTS, \#9251 and \#9252), (p)p38 (CTS, \#4631S and \#9212) and (p)c-jun (CTS, \#3270P and \#9165P). Secondary antibodies conjugated with horseradish peroxidase (HRP) against rabbit (CTS, \#7074S), mouse (CTS, \#7076S) or rat (Santa Cruz, E2313) were next detected using enhanced chemi-luminescence, visualized with an Artemis CCD Camera and quantified using ImageJ.

Enzyme treatments were carried out on macrophage cell lysates that were lysed in RIPA SDS. After determining the protein concentration of the sample with a Micro BCA Protein 
assay kit, $10 \mu \mathrm{g}$ of protein lysate $(10 \mathrm{ul})$ was denaturated by the addition of denaturation buffer (supplied with PGNase; Bioke, P0705S) and heated for 3 minutes at $100^{\circ} \mathrm{C}$. Then, enzymes were added to the lysate and incubated according to the standard protocol (PGNase, Biolabs P0705S or Current Protocol in Molecular Biology, 17.13B 8). The enzymes used were Chondroitinase ABC (Sigma, C3667), Endo-B-galactidase (Sigma, C6920), Heparinase III (Sigma, H8891), Chondroitinase B (Sigma, C8058) and PGNase (Bioke, P0705S). For every enzyme, a control sample was incubated at the same temperature and time. Finally, protein glycosylation was analyzed by immunoblotting to determine size changes.

\section{Structure and Docking Prediction}

We used the I-TASSER web service $\left[\mathrm{MM}^{8}{ }^{8}\right.$, $\left[\mathrm{MM} 2{ }^{9}\right],\left[\mathrm{MM} 3{ }^{10}\right]$ to predict the $3 \mathrm{D}$ structure of OGN (on 2014-07-12). The default parameters for I-TASSER were used. As an input sequence for OGN, the amino acid sequence from UniProt (Q62000) was used. The docking prediction of TLR4 (PDB ID: 2Z64, chain A) and OGN was calculated using the Hex web service [MM4 ${ }^{11}$ ]. Again, the default parameters were used. Visualization of the resulting structures was performed in Jmol (14.2.2, http://www.jmol.org/).

\section{Co-immunoprecipitation and Cell Fractionation}

Fifty microliters of sheep anti-mouse M280 Dynabeads (Invitrogen, 11201D) was prepared according to the manufacturer's protocol and incubated with either $4 \mu \mathrm{g}$ of anti-TLR4 (Abcam, $\mathrm{ab} 22048$ ) or $4 \mu \mathrm{g}$ of normal mouse serum (NMS; Sigma, M5905) in $50 \mu \mathrm{l}$ for $2 \mathrm{~h}$ at $4^{\circ} \mathrm{C}$. One bacterial plate with macrophages was lysed in PBS, spun down for $10 \mathrm{~min}$ at $1200 \mathrm{rpm}$ and dissolved in $5 \mathrm{ml}$ of IP buffer $(150 \mathrm{mM} \mathrm{NaCl}, 20 \mathrm{mM}$ Tris- $\mathrm{HCl}, 5 \mathrm{mM}$ EDTA, 1\% Triton + Proteinase Inhibitor Cocktail, Roche, 11697498001) for $1 \mathrm{~h}$ at $4^{\circ} \mathrm{C}$ in a head-to-head rotator. After determining the protein concentration (Thermo Scientific, Lot MJ162220), $300 \mu \mathrm{g}$ of protein lysate in $200 \mu \mathrm{l}$ of IP buffer was mixed with preincubated TLR4- or NMS-sheep antimouse M280 Dynabeads overnight at $4^{\circ} \mathrm{C}$. The next day, the Dynabeads were washed three times and the pellets were dissolved in $50 \mu \mathrm{l}$ of $2 \mathrm{x}$ sample buffer. Proteins were analyzed by western blotting as previously described.

Cell fractionation was performed by lysing macrophages that were seeded in 6-well plates (800,000 cells/well) in $200 \mu \mathrm{l}$ of ice cold hypotonic lysis buffer $(5 \mathrm{mM}$ Tris- $\mathrm{HCl}, \mathrm{pH} 7.4,5$ $\mathrm{mM} \mathrm{NaCl}, 2 \mathrm{mM}$ EDTA, $1 \mathrm{mM} \mathrm{CaCl} 2,1 \mathrm{mM} \mathrm{MgCl} 2,2 \mathrm{mM}$ DTT + Proteinase Inhibitor Cocktail, Roche, 11697498001), after which they were spun down for $1 \mathrm{~h}$ at max speed $(13200 \mathrm{rpm})$ at $4^{\circ} \mathrm{C}$. The pellet or membrane fraction was dissolved in $50 \mu \mathrm{l}$ of $2 \mathrm{x}$ sample buffer. The cytosol fraction was dissolved 1:4 with 4x sample buffer, and twice the amount was loaded compared to that of the membrane fraction. Proteins were analyzed by western blotting as previously described.

\section{HeK Blue Cell Experiments}

HEK-Blue $^{\mathrm{TM}}$ mTLR4 reporting cells were purchased through InvivoGen, were obtained by co-transfection of the murine TLR4, MD-2 and CD14 co-receptor genes and an inducible SEAP reporter gene into HEK293 cells (HEK-Blue ${ }^{\mathrm{TM}}$ mTLR4, hkb-mtlr4, InvivoGen) and were cultured according to the manufacturer's protocol. As the SEAP reporter gene was placed under the control of an IFN- $\gamma$ minimal promoter fused to five NFKB and AP1-binding sites, stimulation with a TLR4 ligand activates NFאB and AP1, which induces the production of SEAP. SEAP production was measured using QUANTI Blue (QUANTI-Blue ${ }^{\mathrm{TM}}$, rep-qb1, InvivoGen) according to the manufacturer's protocol. Cells were stimulated with either 2 or 
$10 \mathrm{ng} / \mathrm{ml}$ LPS (Sigma) and all other TLR ligands (Mouse TLR1-9 Agonist Kit, tlrl-kit1mw, InvivoGen; TLR specific ligands: Pam3CSK4 for TLR1/2, Poly(I:C) (HMW) for TLR3, LPSEK for TLR4, FLA-ST for TLR5, FLS-1 for TLR6/2 and ODN1826 for TLR9) were stimulated at the concentrations described in the manufacturers protocols. Before stimulation the cells were transfected with either Silencer ${ }^{\bullet}$ Negative Control siRNA (Life Technologies, AM4611) or Silencer ${ }^{\circledast}$ OGN siRNA (Life Technologies, L-090181-01) by using Lipopfectamine 2000 (Invitrogen, 11668-030) according to manufacturer's protocol. Fourtyeight hours after transfection the cells were seeded in 96-wells plates and the TLR ligands were added.

\section{Bone Marrow-DERIVEd MaCrophage Isolation AND EXPERIMENTS}

Both tibias and femurs were collected from OGN WT and KO mice in ice cold PBS and stripped of muscles. After placing the stripped bones in $70 \%$ ethanol for approximately 45 seconds, they were again washed with PBS, after which the ends were removed and the inner bone marrow was flushed with a 25-G syringe filled with cold PBS. After flushing all of the bones, a single cell suspension was obtained by pushing the suspension through a $100 \mu \mathrm{m}$ Nylon cell strainer. Cells were spun down at $1200 \mathrm{rpm}$, placed in bacterial plates in RPMI 1640 with 15\% LCM for cell culture, and differentiated for approximately 8 to 10 days; medium was added or replaced every 2-3 days. Experiments were performed after differentiation for 8-10 days. Cells were counted using a Burker Turk cell counting chamber, and 400,000 cells were seeded in 12-well plates. The cells were stimulated the next day, after the cells had adhered to the plastic, with $10 \mathrm{ng} / \mathrm{ml}$ LPS (Sigma). At the end of the experiments, the cells were directly harvested in RLT buffer for RNA isolation and sample buffer for immunoblotting.

\section{Human Buffy Coat Preparation and Dynabead Cell Isolation}

Blood samples were collected using 5-ml BD Vacutainer K2E (EDTA) tubes with erythrocyte lysis buffer $(8.4 \mathrm{~g} \mathrm{NH} 4 \mathrm{Cl}+0.84 \mathrm{~g} \mathrm{NaHCO} 3$ in $1 \mathrm{~L}$ Aqua Dest, $\mathrm{pH}$ 7.2-7.4). Blood was spun down at $200 \mathrm{~g}$ with the brake off for 20 minutes. Platelet-rich plasma was removed, after which the cells were incubated for 3 minutes with $10 \mathrm{ml}$ of ice cold erythrocyte lysis buffer. Next, the cells were spun down at $1500 \mathrm{rpm}$ for 10 minutes. Erythrocyte lysis was repeated if erythrocytes were still present because this would interfere with Dynabead cell isolation. One hundred microliters of Dynabeads ${ }^{\oplus}$ M-280 Sheep Anti-Rabbit IgG (Invitrogen, 11203D) was incubated with $8 \mu \mathrm{g}$ of anti-OGN antibody (Sigma HPA013132) overnight at $4^{\circ} \mathrm{C}$ according to the manufacturer's protocol in washing buffer $(\mathrm{Ca} 2+-$ and $\mathrm{Mg} 2+-$ free phosphate buffered saline (PBS) supplemented with $0.1 \%$ bovine serum albumin (BSA) and $2 \mathrm{mM}$ EDTA at $\mathrm{pH}$ 7.4). The next day, the beads were washed 3 times with washing buffer, after which they were incubated with the buffy coat lysates. The buffy coat lysates were washed twice with PBS with $0.1 \%$ BSA by centrifugation at $225 \mathrm{~g}$ for $8 \mathrm{~min}$ at $2-8^{\circ} \mathrm{C}$ and re-suspended at $1 \times 108 \mathrm{cells} / \mathrm{ml}$ in PBS with $0.1 \%$ BSA. One milliliter of cell suspension was incubated with $100 \mu$ lof beads at $2-8^{\circ} \mathrm{C}$ for $30 \mathrm{~min}$ with gentle tilting and rotation. After washing the bead-bound cells twice, they were resuspended in $100 \mu \mathrm{L}$ of buffer for FACS analysis. The term input is referring to the complete human buffy coat samples that were used. Addition of the OGN bound beads removed all OGN-positive leukocytes form these total buffy coats. The remaining fraction was referred to as OGN-negative. All fractions were analyzed by FACS. Also, the phosphorylation of $\mathrm{c}$ jun was determined by dissolving all fractions in sample buffer, after determining total protein content by using Micro BCA ${ }^{\mathrm{TM}}$ Protein Assay Kit (Life Technologies, 23235) 


\section{Human SAmples}

For Immunohistochemical analysis, histological section were obtained from sixteen patients suggestive of viral myocarditis and of fourteen post mortem 'healthy controls' manually selected based on clinicopathological reports from the host university hospital (Charité, Berlin, Germany) by an experienced pathologist (E.V.), who was not involved in the preclinical data acquisition. The ethical commission of Charité Germany approved the study.For western blot analysis, human endomyocardial biopsy samples suggestive of myocardial infarction of post mortem 'healthy controls' were manually selected based on clinicopathological reports from the host university hospital (MUMC, Maastricht, The Netherlands) by an experienced pathologist (E.V.), who was not involved in the preclinical data acquisition. The ethical commission of MUMC Maastricht approved the study. Buffy coats for western blot analysis and flow cytometry were collected from healthy volunteers after providing proper informed consent.

\section{Flow Cytometry}

Cells were stained with anti-CD3-FITC, CD66b-FITC, CD19-FITC, CD19-BV421, CD56-PE and HLA-DR-V55 (BD Biosciences) and measured with FACS-Canto II (BD Biosciences). Results were analysed with FACSdiva software (BD Biosciences).

\section{RTPCR}

Real-time reverse transcriptase-polymerase chain reaction (RT-PCR) analysis was performed (Bio-Rad, Maastricht, Netherlands) to determine the transcript levels of the following genes:

CVB3

IL-6

TNF $\alpha$

IL-1 $\beta$

IL-12

OGN

XYLT2

GlcNact

Gsgalnact

Gluc-C5-Epimerase

GAPDH forward primer ACGAATCCCAGTGTGTTTTGG reverse primer TGCTCAAAAACGGTATGGACAT at $63.9^{\circ} \mathrm{C}$. forward primer CAAAGCCAGAGTCCTTCAGAG reverse primer GCCACTCCTTCTGTGACTCC at $63.9^{\circ} \mathrm{C}$. forward primer CCACCACGCTCTTCTGTCTA reverse primer AGGGTCTGGGCCATAGAACT at $63.9^{\circ} \mathrm{C}$. forward primer GTAATGAAAGACGGCACACC reverse primer TACCAGTTGGGGAACTCTGC at $63.9^{\circ} \mathrm{C}$. forward primer CTAGACAAGGGCATGCTGGT reverse primer TCTCCCACAGGAGGTTTCTG at $63.9^{\circ} \mathrm{C}$. forward primer CCTGGAATCTGTGCCTCCTA reverse primer TCCAGGCGAATCTCTTCAAT at $63.9^{\circ} \mathrm{C}$. forward primer AGAGTCTGGAGGTTGGTACTGAG reverse primer GCTACGGGCTCATCCAGTG at $61^{\circ} \mathrm{C}$. forward primer GCTACTTCTAGAACCATTCTTGTCA reverse primer GCATAAGTTTCGTTGGTTCTGT at $61^{\circ} \mathrm{C}$. forward primer GACTCGCCGAGGCTTTACTC reverse primer AGTCATAGCCCCAAAGTGGC at $61^{\circ} \mathrm{C}$. forward primer GTGGAGTTGAAGGTGTGCCA reverse primer GTGAGGGGGTTTCTCGGTTA at $61^{\circ} \mathrm{C}$. forward primer GGTGGACCTCATGGCCTACA reverse primer CTCTCTTGCTCAGTGTCCTTGCT at $63.9^{\circ} \mathrm{C}$. 
The primer sequences of these genes were determined by NCBI software analysis of Primer BLAST. The details of the sequences and thermal cycling conditions were according to the standard protocol. Data were acquired and analyzed with IQ5 software (Bio-Rad, Maastricht, Netherlands).

\section{Statistical Analysis}

The results represent the mean \pm SEM unless otherwise indicated. For murine studies, D'Agistino and Pearson's omnibus normality test was performed. Statistical significance was determined by unpaired Student's t test and one-way ANOVA when the data were normally distributed. Wilcoxon, Mann-Whitney and Kruskal-Wallis tests with Dunn's Multiple Comparison test were used for non-parametric data as indicated. The Gehan-Breslow-Wilcoxon test was used for survival analysis. Statistical analyses were performed with GraphPad Prism software v5.0 with ${ }^{*} \mathrm{p}<0.05,{ }^{* *} \mathrm{p}<0.01$, and ${ }^{* * *} \mathrm{p}<0.001$.

\section{RESULTS}

\section{Different OGN Variants are Present in Different Cardiac Pathologies}

First, protein expression of OGN was studied in murine hearts 7 days after intraperitoneal injection of Coxsackie B3 virus (CVB3). The sole presence of a new yet undescribed cardiac OGN variant of approximately $72-\mathrm{kDa}$ was found in the murine hearts with viral myocarditis (Figure 1A). Contrarily, a $34-\mathrm{kDa}$ OGN variant was highly abundant in murine myocardial infarcts (Figure 1A), which may be in accordance with its association with collagen fibrillogenesis 12,13 . When further analyzing OGN protein expression in different tissues, we identified very distinct yet consistent glycosylation patterns. Murine corneal tissues had a high abundance of the $50-\mathrm{kDa}$ keratan sulfate variant ${ }^{4}$ which is in line with literature findings. Tissues with high collagen and connective tissue contents, such as bone, tail and skin, presented with the 34-kDa variant (Figure 1B). Furthermore, human tissue and blood samples demonstrated a comparable occurrence of the OGN protein variants. In post mortem left ventricular tissues from ischemic patients in which the collagen content, as a consequence of fibrosis, is high, the 34-kDa OGN variant was detected, while it could not be found in control patients (Figure 1C). This is supported by immunohistochemical staining for OGN in human myocardial infarcts, revealing that OGN staining clearly matched cardiac fibrosis ${ }^{14}$. Interestingly, the $72-\mathrm{kDa}$ variant was highly expressed on human circulating leukocytes (Figure 1D), whereas it could not be detected in post mortem splenic tissue (Figure 1C). Therefore, we hypothesized that the presence of distinct OGN variants may be associated with the specific underlying pathophysiological processes. In viral myocarditis patients, where there is both fibrosis and inflammation ${ }^{15}$, we identified an increase in OGN staining compared to control hearts (Figure $1 \mathrm{E}, \mathrm{F}$ ). Here, positive OGN staining was found in areas with fibrosis (Figure 1G) but also on immune cells (Figure 1H). Correspondingly, in our murine model of CVB3 myocarditis, where inflammation is present but fibrosis is not ${ }^{16}$, OGN staining predominated on leukocytes (Figure 1H,I). Consequently, the observed variation in size of this proteoglycan in relation to either cardiac fibrosis $(34-\mathrm{kDa})$ or cardiac inflammation $(72-\mathrm{kDa})$ led us to hypothesize that differential glycosylation may be in control. 


\section{OGN is Present on Cardiac and Circulating Innate Immune Cells}

As the $72-\mathrm{kDa}$ 'inflammatory' OGN (iOGN) was primarily found in viral myocarditis on leukocytes, we further analyzed its specific expression in circulatory leukocytes versus cardiac leukocytes using immunofluorescence and flow cytometry in both mice and humans. OGN clearly co-stained with both murine neutrophil (Gr1)- and monocyte/macrophage

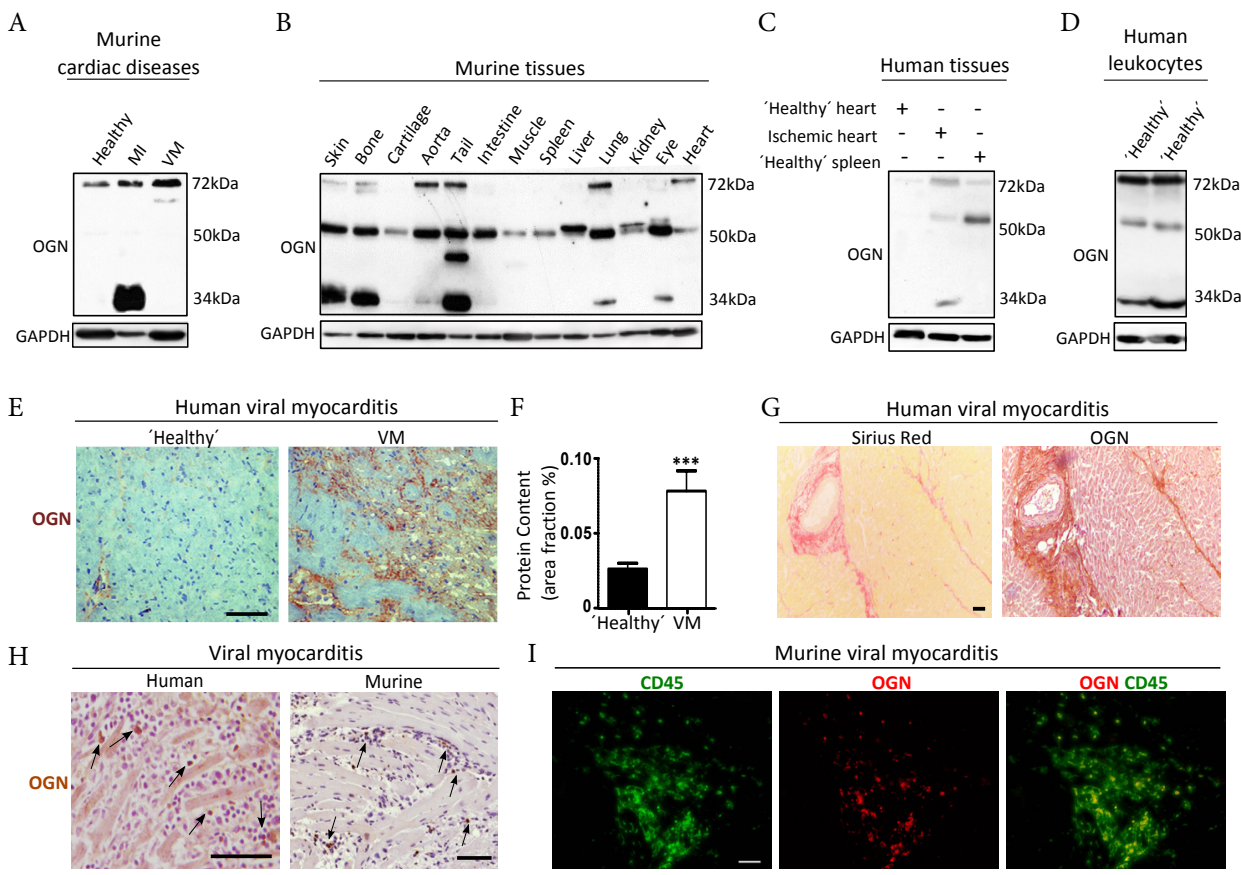

Figure 1 Murine and human tissues express different OGN VARiants in Distinct CardiaC Diseases. (A) Western blot analysis for OGN revealed a small variant $(34 \mathrm{kDa})$ in murine myocardial infarction, whereas in murine viral myocarditis a large variant $(72 \mathrm{kDa})$ was present $(\mathrm{n} \geq 4)$. (B) Differential expression of the main OGN variants in various healthy murine tissues. (C) Western blot analysis for OGN in human ischemic myocardial tissue showing increased expression of the large $(72 \mathrm{kDa})$ and the small $(34 \mathrm{kDa})$ OGN variants relative to those in the control cardiac tissue. (D) Human buffy coat revealed a similar presence of the OGN variants with high abundance of the $72-\mathrm{kDa}$ variant, which was barely detectable in human splenic tissues. (E) Increased immunohistochemical OGN staining was found in patients diagnosed with myocarditis. (F) Quantification of OGN staining in patients diagnosed with myocarditis $(\mathrm{n} \geq 14$ ). (G) OGN expression in human myocarditis biopsies coincided with fibrosis as shown by Sirius red staining. (H) OGN staining was also found on leukocytes in human myocarditis biopsies as well as in the hearts of mice subjected to CVB3-induced myocarditis. (I) Immunofluoresence demonstrated the co-localization of OGN with CD45+ leukocytes in the hearts of mice subjected to virus myocarditis. All experiments were repeated at least twice. Scale bar: $50 \mu \mathrm{m}$. VM: viral myocarditis; MI: myocardial infarction

(Mac3)-markers in the myocardium (Figure 2A). To verify that the relevance of OGN wasn't exclusive for mice we confirmed its occurrence on circulating human leukocytes, the source for cardiac inflammation in response to CVB3 infection. Human peripheral leukocytes in blood smears and buffy coats demonstrated a similar colocalization of OGN with human peripheral neutrophil- and monocyte-markers (Figure 2B). Separating OGN-positive peripheral leukocytes $(\mathrm{OGN}+\mathrm{ve}$ ) from the total circulating peripheral leukocytes by using OGN-bound magnetic Dynabeads allowed us to better identify the OGN expressing circulating immune cell population by FACS analysis. As approximately $50-70 \%$ of all human circulating leukocytes 
A

Myocardial leukocytes

Mouse VM
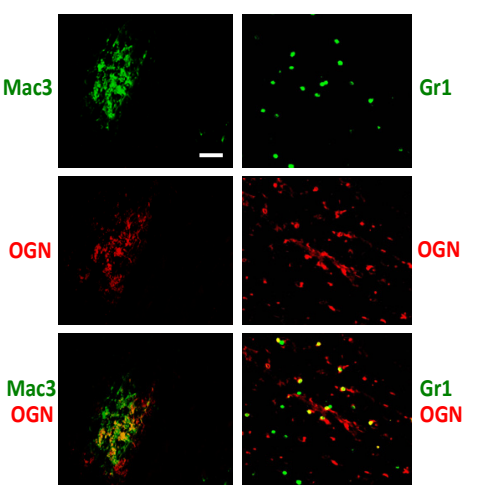

C

Human circulating leukocytes

Healthy individuals

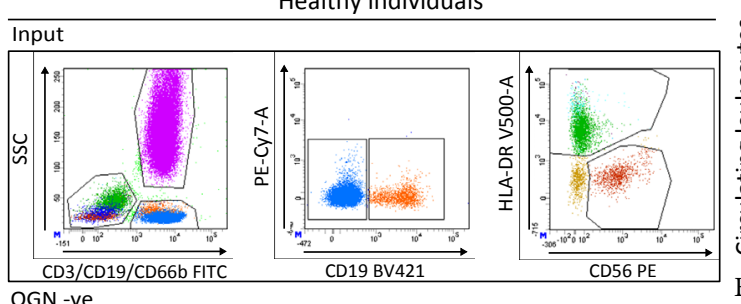

\section{OGN -ve}

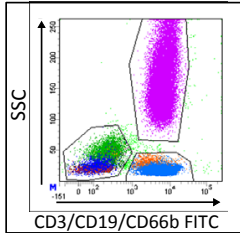

OGN +ve

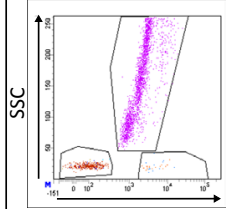

CD3/CD19/CD66b FITC

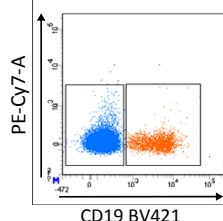

CD19 BV42

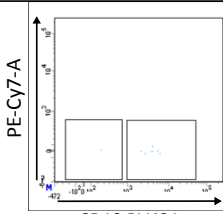

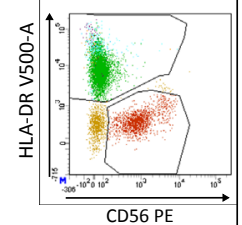

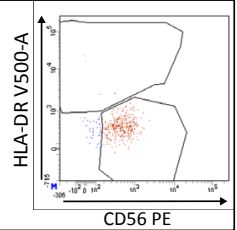

Human circulating leukocytes

Healthy individuals
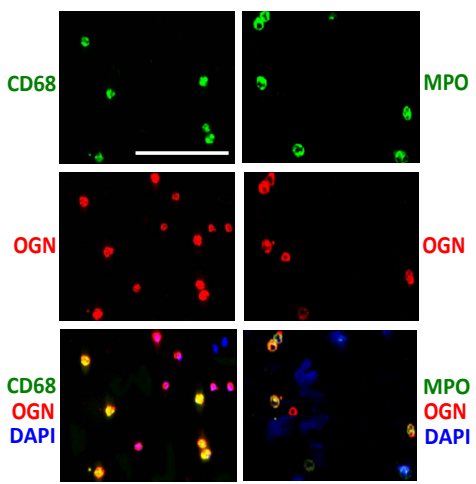

D
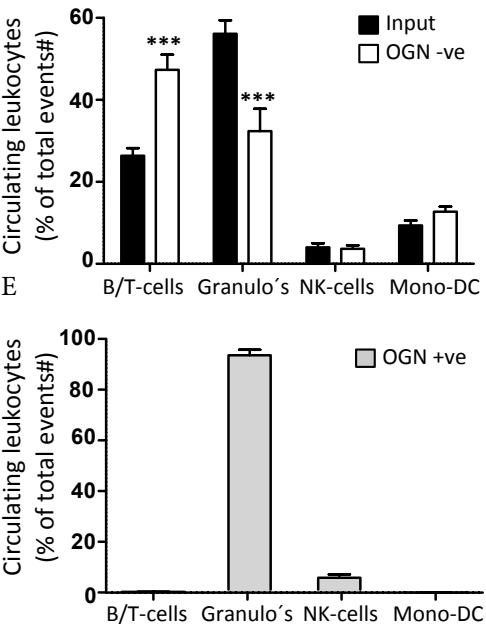

F

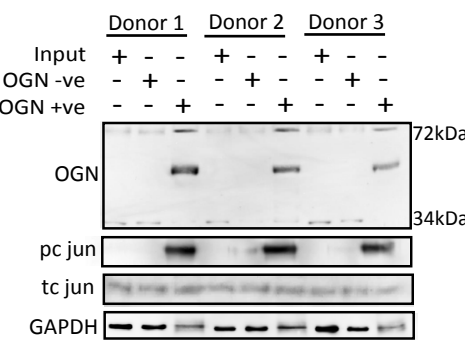

Figure 2 The 72-KDa iOGN was found on Cardiac and Circulating innate immune Cells.

(A) Murine cardiac monocytes/macrophages (Mac-3) and neutrophils (Gr1) expressed OGN during CVB3-induced myocarditis. (B) Circulating human monocytes and neutrophils also expressed OGN. (C) Representative FACS plots of total human circulating leukocytes, OGN-negative (OGN -ve) and -positive (OGN +ve) circulating leukocytes. (D-E) FACS analysis revealed that the OGN-positive circulating leukocytes consisted mostly of neutrophils. (F) The

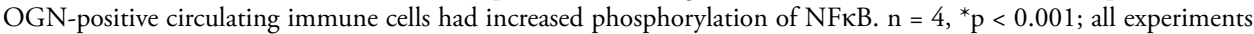
were repeated at least twice. Scale bar: $50 \mu \mathrm{m}$. 
are composed of neutrophils, FACS analyses revealed the presence of OGN predominantly on peripheral neutrophils (Figure 2C-E). Interestingly, these circulating iOGN-positive leukocytes showed significantly more phosphorylation of c jun than the iOGN negative leukocytes, suggesting very distinct phenotypic characteristics for these iOGN-positive innate immune cells (Figure 2F).

\section{Glycosylation Leads to Different OGN Variants}

Because glycosylation is a very dynamic step that adds glycans or glycosaminoglycans to proteins, we explored whether the production of these different OGNs originated from the single $32-\mathrm{kD}$ a protein backbone. Therefore, to better characterize the glycosylation of the three main OGN protein variants found in the heart $(34,50$ and $72 \mathrm{kDa})$, we treated protein lysates with specific enzymes that are able to cleave the different glycosaminoglycans or glycans. We found that the 50-kDa OGN has N-linked glycans and N-linked keratan sulfate attached (Figure 3A). The addition of O-linked dermatan sulfate resulted in the formation of the 34$\mathrm{kDa}$ variant (Figure 3A). Furthermore, the addition of chondroitin sulfate led to the formation of the $72-\mathrm{kDa}$ variant, which is potentially a dimer that could only be reduced by treatment with all enzymes simultaneously (Figure 3A). In brief, the 32-kDa protein core of OGN can be post-translationally modified by either $\mathrm{O}$ - or $\mathrm{N}$-linked glycosylation (Figure 3B).

Interestingly, whereas the $72-\mathrm{kDa}$ inflammatory OGN (iOGN) variant was primarily located in the cell membrane of both human peripheral leukocytes and murine bone marrowderived macrophages (BMDMs), the 34-kDa fibrosis OGN (fOGN) was located in the cytosol, as revealed by cell fractionation (Figure 3C,E). Furthermore, stimulation of BMDMs with lipopolysaccharides (LPS) not only resulted in a significant increase in the transcript levels of OGN (Figure 3D), protein expression of the 72-kDa iOGN membrane variant also increased in response to LPS (Figure 3E). Furthermore, the transcription and translation of OGN was paralleled by an increased gene expression of key glycosylation enzymes, such as Xylosyl transferase 2 (XYLT2) and D-glucuronyl C5-epimerase (Supplementary Figure 1). LPS thus increases the transcription, translation and glycosylation of OGN.

\section{Membrane-Bound Inflammatory IOGN INTERACTS With TLR4 IN LEUKOCYTES}

Next, we sought to accurately understand the biological role of the $72-\mathrm{kDa}$ iOGN that was present on innate immune cells where it was responsible for the apparent "active" phenotypic appearance of these cells. Given the ability of leucine-rich repeats to interact with TLRs ${ }^{17}$, we speculated that this $72-\mathrm{kDa}$ membrane-anchored OGN might influence TLR signaling. In silico structure modeling predicted a potential interaction between the concave leucinerich surface of OGN and the extracellular LRR domain of TLR4, that has been implicated in CVB3-myocarditis disease severity ${ }^{18,19}$ (Figure 4A). Therefore, HEK-Blue ${ }^{\mathrm{TM}}$-mTLR cells containing an inducible secreted embryonic alkaline phosphatase (SEAP) reporter gene were stimulated with TLR specific ligands (Pam3CSK4 for TLR1/2, Poly(I:C) (HMW) for TLR3, LPS-EK for TLR4, FLA-ST for TLR5, FLS-1 for TLR6/2 and ODN1826 for TLR9) with and without OGN knockdown (Supplementary Figure 2A). OGN knockdown significantly decreased TLR3, -4 and -5 signaling (Figure 4B), supporting a possible interaction between OGN and TLRs. Moreover, OGN co-immunoprecipitated with TLR4 in both human peripheral leukocytes as well as in BMDM lysates (Figure 4C,D). In line with this observation, immunofluorescence showed co-expression of OGN with TLR4 on primary macrophages (Figure 4E). 
As approximately $8 \pm 2 \%$ of the human peripheral circulating leukocytes expressing OGN on their surface appear to be more "activated" (Figure 2D-F), we wondered whether this may be a consequence of augmented TLR4 signaling. To validate the interaction of OGN with TLR4 in vivo, we reasoned that a lack of OGN on circulating leukocytes in OGN null mice, may alter TLR4 signaling in the mouse model of endotoxemia. We therefore subjected OGN WT and KO mice to endotoxemia, a model of septic shock where TLR4 activation is, in part, driving pathogenesis. Although mortality was severe in both genotypes, OGN WT mice died earlier than their OGN KO littermates (Table 1, $\mathrm{p}=0.05$; Median survival: $8 \mathrm{~h}$ in WT versus $14 \mathrm{~h}$ in $\mathrm{KO}$; ratio 0.5714 with $95 \% \mathrm{CI}$ of $0.030-1.113)$. The serum levels of IL-12 and IL-1 $\beta$ were also measured and significantly higher in OGN WT mice than in their KO littermates $1 \mathrm{~h}$ after receiving an intravenous dose of LPS (Table 1). Because only a small subset of circulating leukocytes expressed iOGN, no clear differences were found in the serum TNF $\alpha$ and IL-6 levels (Table 1). Collectively, these findings suggest that iOGN present on innate immune cells is crucial for boosting TLR4 activation.

Table 1 iOgN on circulating leukocytes enhances TLR 4 activation in a Murine model for ENDOTOXEMIA.

\begin{tabular}{|c|c|c|c|}
\hline & $\begin{array}{l}\text { WT } \\
(n=23)\end{array}$ & $\begin{array}{c}\text { KO } \\
(n=22)\end{array}$ & \\
\hline $\begin{array}{l}\text { Median survival } \\
\text { (hours) }\end{array}$ & 8 & 14 & $\begin{array}{c}\text { Ratio } 0,57 \text { (95\% CI } \\
\text { of ratio } 0,03 \text { to } 1,11) \\
\text { Log-rank (Mantel Cox) } \\
\text { test } \mathrm{p}=0.05\end{array}$ \\
\hline $\mathrm{TNF} \alpha \quad(\mathrm{pg} / \mathrm{ml})$ & $5796 \pm 570,5$ & $5862 \pm 505,1$ & $\mathrm{p}=0.90$ \\
\hline IL-6 $\quad(\mathrm{pg} / \mathrm{ml})$ & $56191 \pm 237,9$ & $55820 \pm 294,4$ & $\mathrm{p}=0.30$ \\
\hline IL-12 (pg/ml) & $396,3 \pm 25,7$ & $320 \pm 24,4$ & $\mathrm{p}=0.03$ \\
\hline IL-1 $\quad(\mathrm{pg} / \mathrm{ml})$ & $17,5 \pm 1,5$ & $12,5 \pm 1,4$ & $\mathrm{p}=0.02$ \\
\hline
\end{tabular}


A

\begin{tabular}{|c|c|c|c|c|c|c|}
\hline \multirow[b]{2}{*}{ Control } & \multicolumn{5}{|c|}{ glycosylation } & both \\
\hline & + & - & - & - & - & - \\
\hline Hep III $1 \mathrm{mU} / \mathrm{ul}$ & - & + & - & - & - & - \\
\hline Chndr ABC $1 \mathrm{mU} / \mathrm{ul}$ & - & - & + & - & - & - \\
\hline EndoB dase $1 \mathrm{mU} / \mathrm{ul}$ & - & - & - & + & - & - \\
\hline Chndr B $1 \mathrm{mU} / \mathrm{ul}$ & - & - & - & - & + & $-\quad+$ \\
\hline PGNase $500 \mathrm{U} / \mathrm{ul}$ & - & - & - & - & $\begin{array}{ll}- & -1\end{array}$ & ++ \\
\hline
\end{tabular}

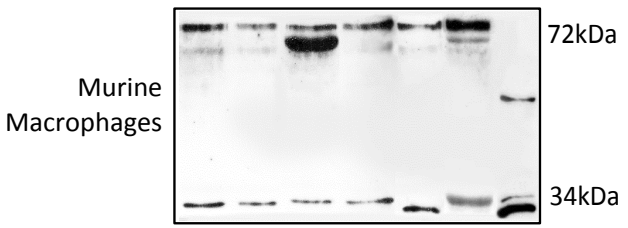

B

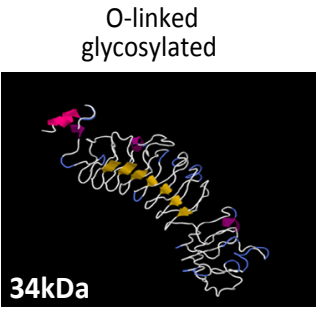

Dermatan sulfate
$\mathrm{N}$-linked glycosylated

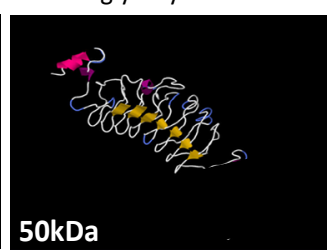

Keratan sulfate + other glycans
$\mathrm{N}$-linked

glycosylation

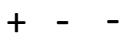

- -

- -

$-+$

- -

$-\quad+$

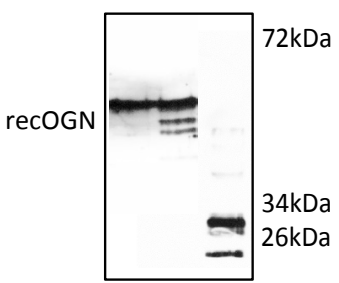

O-linked glycosylated

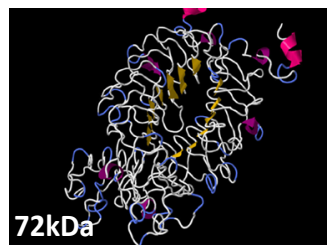

Chondroitin sulfate

C

D

$\bar{E}$
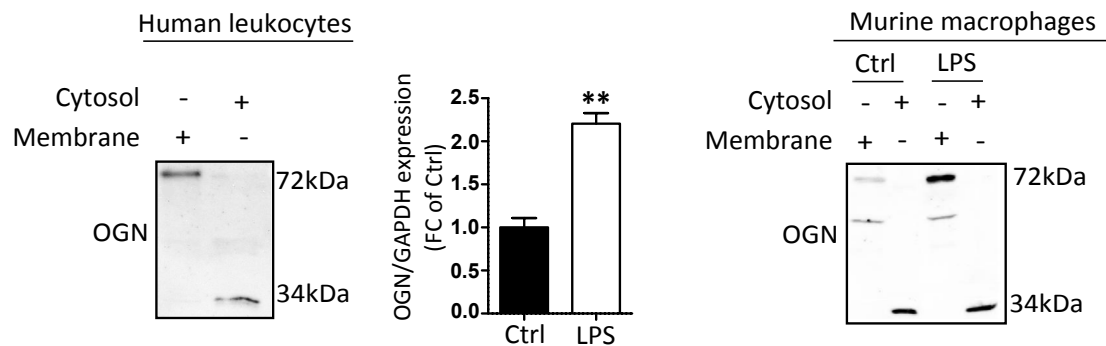

Figure 3 Glycosylation of the 32-KDa OGN core protein results in the production of Different PROTEIN VARIANTS.

(A) Enzyme treatment of macrophage protein lysates revealed the differential presence of glycans and glycosaminoglycans; treatment with chondroitinase $\mathrm{ABC}$ reduced the size of the $72-\mathrm{kDa}$ protein variant, indicating that chondroitin and dermatan sulfate is attached, whereas treatment with chondroitinase B only slightly reduced the size of the $34-\mathrm{kDa}$ variant, indicating that it only has dermatan sulfate attached. The simultaneous addition of all of the enzymes reduced he protein glycosylation of both the $34-\mathrm{kDa}$ and $72-\mathrm{kDa}$ variants entirely. Treatment of the 50$\mathrm{kDa}$ OGN variant with PGNase reduced the size detected on western blot significantly, indicating that it is N-linked glycosylated. (B) Predicted structures of the OGN variants and their respective glycosylations. (C) Cell fractionation of fresh human buffy coat lysates revealed the presence of the $72-\mathrm{kDa}$ OGN variant in the cell membrane, whereas the $34-\mathrm{kDa}$ variant was found in the cytosol. (D-E) In mouse bone marrow derived macrophages, LPS stimulation increased the expression of OGN in the cell membrane. All experiments were repeated at least twice. 
A

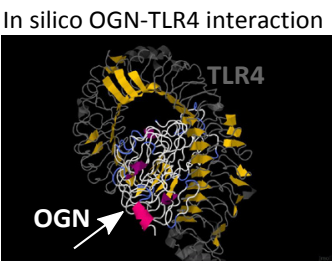

D

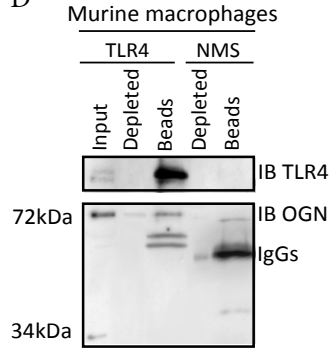

B

C

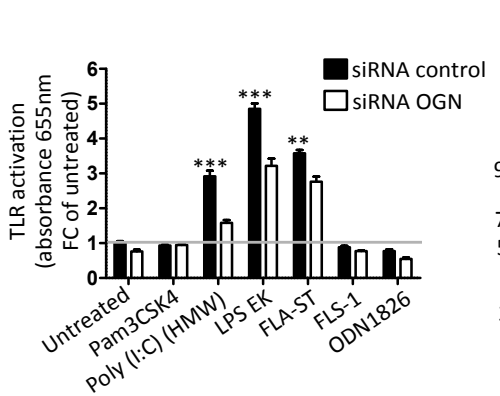

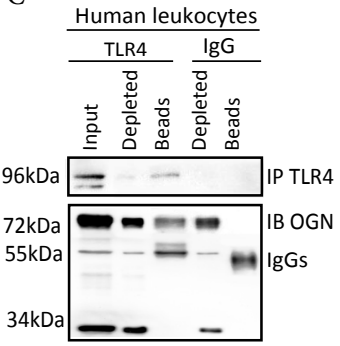

Figure 4 Membrane bound iOGN interacts with TLR4 in Leukocytes.

Docking predictions of TLR4 and OGN reveal a potential interaction between these proteins via their leucine-rich repeats. (B) HEK-Blue ${ }^{\mathrm{TM}}$-mTLR cells containing an inducible SEAP reporter gene were stimulated with TLR specific ligands (Pam3CSK4 for TLR1/2, Poly(I:C) (HMW) for TLR3, LPS-EK for TLR4, FLA-ST for TLR5, FLS-1 for TLR6/2 and ODN1826 for TLR9) with and without OGN knockdown. OGN knockdown reduced the activation of TLR3, -4 and -5. (C-D) OGN co-immunoprecipitated with TLR4 in human peripheral leukocytes and murine bone marrow-derived macrophages. (E) Confocal immunofluoresence revealing the co-localization of OGN with TLR4 in primary murine macrophages. $\mathrm{n} \geq 4,{ }^{*} \mathrm{p}<0.001$. All experiments were repeated at least twice. Scale bar: $50 \mu \mathrm{m}$. 
OGN PROMOTES TLR4 ACTIVATION BY ENHANCING MAPK-INDUCED CYTOKINE PRODUCTION

As TLR4 activation leads to the expression of pro-inflammatory cytokines due to phosphorylation of many downstream kinases, we wanted to confirm that the TLR4-OGN interaction influenced TLR4 signaling. By stimulating isolated WT and KO macrophages with LPS we first analyzed TLR4 activation by determining pro-inflammatory cytokine expression. The transcript levels of IL- 6 and TNF $\alpha$ were significantly increased in WT macrophages $1 \mathrm{~h}$ after LPS stimulation (Figure 5A,B), resulting in increased protein levels of these cytokines in the medium $6 \mathrm{~h}$ after stimulation $(\mathrm{p}<0.05$, Figure 5E,G). Concordantly, RNA expression of IL-1 $\beta$ and IL-12 in OGN WT macrophages was significantly higher 6 $\mathrm{h}$ after LPS stimulation (Figure 5C,D). Next we examined whether OGN could influence the phosphorylation of several kinases that are needed for TLR4 activation. KO macrophages lacked the significant MyD88 induction that was apparent in WT macrophages in response to LPS ( $p<0.001$, Figure 5F,H). Furthermore, a striking increase of c-jun phosphorylation was found in response to LPS in WT compared to KO macrophages, as a consequence of increased MAPK phosphorylation ( $\mathrm{p}<0.001$, Figure 5F, I-L). Thus, our findings confirm that the interaction of OGN with TLR4 enhances TLR4 activation by increasing proinflammatory cytokine expression by influencing c-jun phosphorylation (Figure 7).
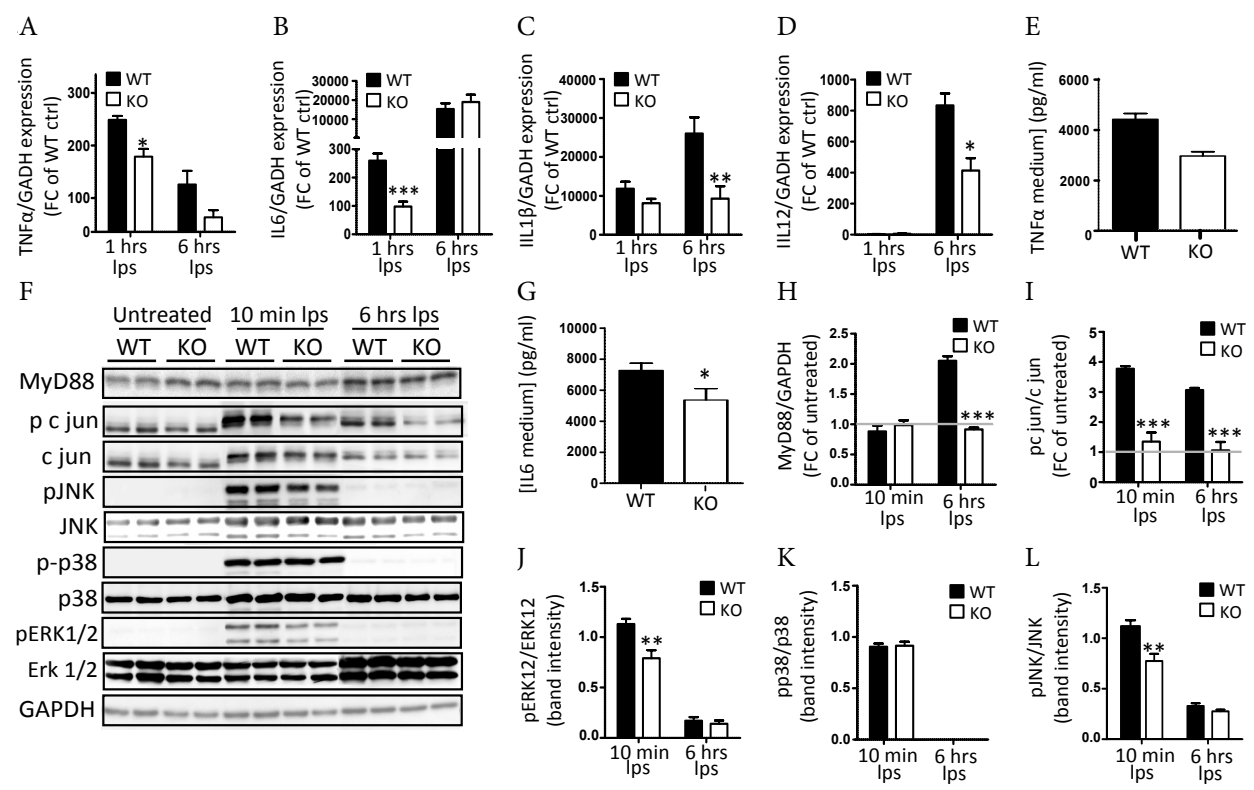

Figure 5 OGN promotes TLR 4 activation by Enhancing MAPK-INDUCED Cytokine production. Bone marrow-derived macrophages (BMDMs) from WT and KO mice were isolated and stimulated with LPS (10 $\mathrm{ng} / \mathrm{ml}$ ). (A-D) LPS stimulation resulted in the blunted induction of pro-inflammatory cytokines TNF $\alpha$ and IL-6 expression ( $1 \mathrm{~h})$ as well as IL-1 $\beta$ and IL-12 at a later stage $(6 \mathrm{~h})(\mathrm{C}, \mathrm{D})$. This difference in TLR4 activation was reflected in the lower TNF $\alpha$ and IL-6 expression levels in the medium (E,G). This increased cytokine production was the result of significant induction of MyD88, that was blunted in the OGN KO BMDMs (F). (H) Quantification of MyD88 in WT and KO BMDMs, $\mathrm{n}=3$. (F) Western blot analysis and further quantification revealed blunted c jun, Erk1/2 and JNK phosphorylation in the KO BMDMs (I-L). All experiments were repeated at least twice. $\mathrm{n} \geq 3 ;{ }^{*} \mathrm{p}<0.05$; ${ }^{* *} \mathrm{p}<0.01 ;{ }^{* * *} \mathrm{p}<0.001$. 


\section{iOGN Present on Innate Immune Cells during Viral Myocarditis Aggravates CARDIAC INFLAMMATION}

Next, we wondered whether the lack of this OGN-TLR4 interaction may influence cardiac inflammation as lack of TLR4 signaling during viral myocarditis has previously been associated with decreased cardiac inflammation ${ }^{20,21}$. Therefore, we subjected male OGN WT and KO mice to the murine model of CVB3-induced myocarditis. The absence of OGN in KO mice significantly reduced cardiac immune cell infiltration relative to that of WT mice 7 days after viral exposure $(8 \pm 1.89 \%$ in OGN WT, $\mathrm{n}=11$ vs $1.9 \pm 0.4 \%$ in $\mathrm{KO}, \mathrm{n}=9 ; \mathrm{p}=0.01)$ (Figure 6A-B). More specifically, infiltration of leukocytes (CD45), lymphocytes (CD3) and macrophages (Mac3) decreased in the absence of OGN (Figure 6C-F), supporting the proinflammatory role of OGN in myocarditis through enhanced TLR4 signaling. Furthermore, while CVB3 viral levels and immune cell recruitment were still similar in the heart at day 4 , IL-1 $\beta$ expression was already significantly increased in the hearts of OGN WT animals, again supporting enhanced TLR4 activation in the presence of iOGN (Figure 6G-I). In conclusion, the absence of OGN decreases immune cell infiltration in CVB3-infected murine hearts, suggesting that increased expression of leukocyte-specific $72 \mathrm{kDa} O G N$ in myocarditis aggravates cardiac inflammation.

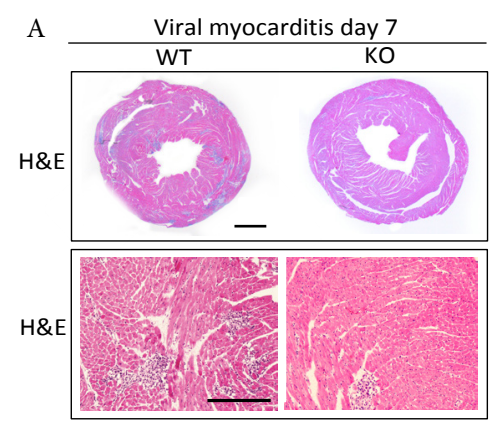

B

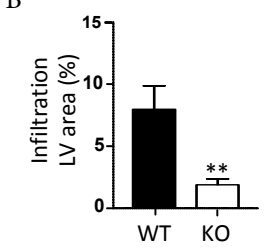

G

$\mathrm{D}$

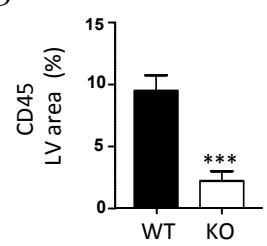

$\mathrm{H}$

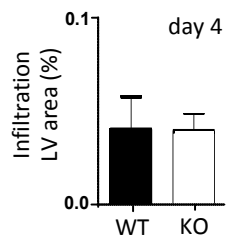

C

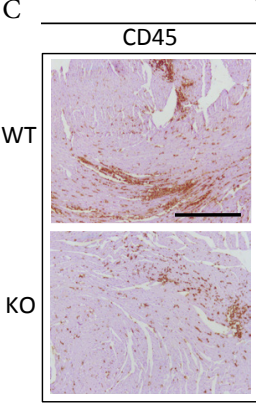

E
Viral myocarditis day 7

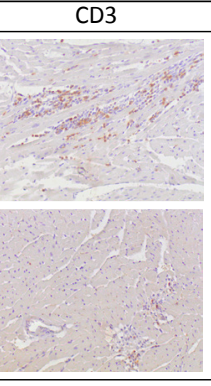

F

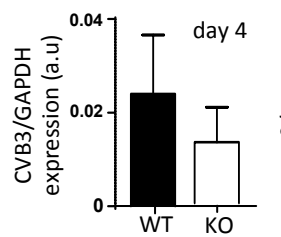

I
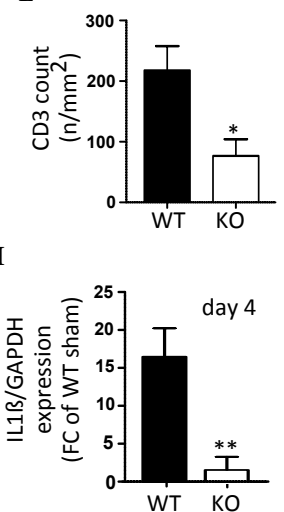

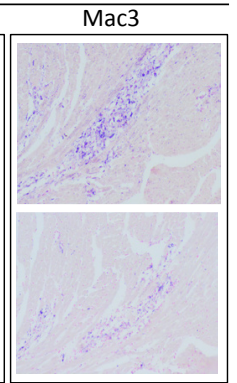

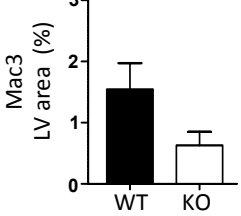

Figure 6 OGN increases Cardiac inflammation in CVB3-INDUCEd murine myocarditis.

Analysis of $\mathrm{H} \& \mathrm{E}$ staining in OGN KO mice revealed significantly reduced cellular infiltration relative to WT mice in human CVB3-induced viral myocarditis (A, scale: $1 \mathrm{~mm}$ top and $50 \mu \mathrm{m}$ bottom) and (B) quantification ( $\mathrm{n} \geq 11$, ${ }^{* *} \mathrm{p}<0.01$ ). (C) Decreased immune infiltration in OGN KO mice was confirmed by the reduced presence of CD 45 positive leukocytes (D), CD3 positive lymphocytes (E) and Mac3 positive macrophages (F). (G) Four days after viral inoculation, the amount of immune cell infiltration was still low and comparable in both genotypes $(n \geq 4)$. (H) Viral levels analyzed by RTPCR were also comparable at this time. (I) Pro-inflammatory cytokine IL-1 $\beta$ expression, on the other hand, was already significantly increased in WT compared to KO mice 4 days after viral exposure. Scale: $50 \mu \mathrm{m}$ 


\section{DisCUSSION}

This study has identified three major OGN variants that are formed via either $\mathrm{N}$ - or O-linked glycosylation and correlated with distinct pathophysiological processes. First, the attachment of N-linked glycans and keratan sulfate to the $50-\mathrm{kDa}$ OGN variant predominates in the eye, where it is important for corneal transparency ${ }^{4}$. The smallest $34-\mathrm{kDa}$ dermatan sulfateOGN variant is highly abundant in fibrotic tissues, as in cardiac infarct scars ${ }^{14}$. This fibrotic dermatan sulfate-OGN (fOGN) is needed for proper collagen fibrillogenesis in the heart ${ }^{12,13}$, which is in line with previous observations where dermatan sulfate is itself involved in kidney fibrosis ${ }^{22,23}$. Interestingly, we uncovered a new O-linked chondroitin sulfate OGN variant (iOGN, $72-\mathrm{kDa}$ ) that is present in the membrane of immune cells, where it binds and activates TLRs. Chondroitin sulfate binding to the protein backbone of OGN may result in putative dimerization as predicted in silico and supported by previous studies for other SLRPs ${ }^{24,25}$. Collectively, these data indicate that a matrix element can have distinct appearances and roles in different disease contexts due to glycosylation, significantly increasing our understanding of the versatile nature of the ECM. Furthermore, as glycosylation is important for the sorting and distribution of proteins within the cell ${ }^{26,27}$, it may also explain the transportation of OGN to either the cell membrane (iOGN) or extracellular environment (fOGN). However, it is still unclear what drives these protein glycosylation processes, as the serial and mutual role of differentially expressed glycosylation enzymes has not been completely elucidated. Hence, at present, proper tools to study these spatio-temporal differences in protein glycosylation are limited.

Nonetheless, we found that this $72-\mathrm{kDa}$ iOGN is present on innate immune cells in the heart or in circulation, where it can bind and activate TLR4 (Figure 7). This may, in part, explain the decreased cardiac inflammation and necrosis in myocarditis in the absence of OGN. Our findings are in line with previous studies revealing that distinct SLRPs, such as decorin and biglycan, directly stimulate TLRs ${ }^{28,29}$. Moreover, it has been speculated that SLRPs like biglycan may cluster TLRs and influence their downstream signaling events ${ }^{30}$. Though, where biglycan acts as direct endogenous ligand of TLR4, OGN acts more like a co-receptor influencing TLR4 signaling in the cell membrane. Aside from influencing cardiac inflammation in viral myocarditis, the interaction of OGN with TLR4 may also influence the development and progression of other cardiac diseases. Therefore, as TLR signaling contributes to the pathogenesis of ischemic myocardial injury ${ }^{31-33}$, myocarditis ${ }^{32-34}$, septic cardiomyopathy ${ }^{32-34}$, atherosclerosis ${ }^{32,35}$ and, most importantly, the progression of heart failure ${ }^{32,33}$, therapeutically modifying these receptors seems promising. In patients, however, the results have been mixed. While, monoclonal antibodies against TLR2 (OPN-305) have been beneficial in reducing ischemia-reperfusion injury in pigs [36] and are safe and well tolerated in healthy volunteers ${ }^{37}$, they still need to be tested in Phase II clinical trials. In comparison, despite promising preclinical studies ${ }^{38,39}$, no clear benefit was identified for the TLR4-specific antagonist Eritoran in elective cardiac surgery patients in a Phase II, doubleblind, placebo-controlled study ${ }^{40}$. The failure of such studies emphasizes the complexity of TLR activation and highlights the need to better understand the exact mechanisms utilized by host-derived ligands ${ }^{41}$.

This apparent duality in TLR signaling may be reflected by the diverse nature of endogenous ligands (e.g., versican ${ }^{42}$, tenascin $\mathrm{C}^{43}$ and hyaluronan ${ }^{44}$, 45 ). Whereas in normal conditions the intact ECM does not allow TLR4 activation, upon disease this inhibition is lost as production of endogenous ligands increases and matrix degradation further liberates other endogenous 
agonist(s) ${ }^{46}$. Moreover, combining glycosylation with increased secretion and/or proteolytic processing of endogenous TLR ligands in the ECM, further diversifies the regulation of TLR responses. The range of TLR ligands as a consequence of these processes differs in various disease conditions ${ }^{47}$. This may explain why, in sterile conditions, such as myocardial infarction, OGN does not seem to influence inflammation ${ }^{2}$, whereas in non-sterile conditions, such as viral myocarditis, it does ${ }^{48,49}$. Where in viral myocarditis both Danger Associated Molecular Patterns (DAMPs) and Pathogen Associated Molecular Patterns (PAMPs) are present and recognized by TLRs, in myocardial infarction the TLR-ligands solely consist of DAMPs. The complete collection of exogenous and endogenous ligands in the extracellular space that are interacting with TLRs will determine the final immunological outcome. Therefore, as TLR3 is clearly implicated in immune activation in viral myocarditis ${ }^{50}$, further exploration of OGN and TLR3 and 5 interactions may further explain the different effect of OGN on cardiac inflammation in different cardiac diseases.

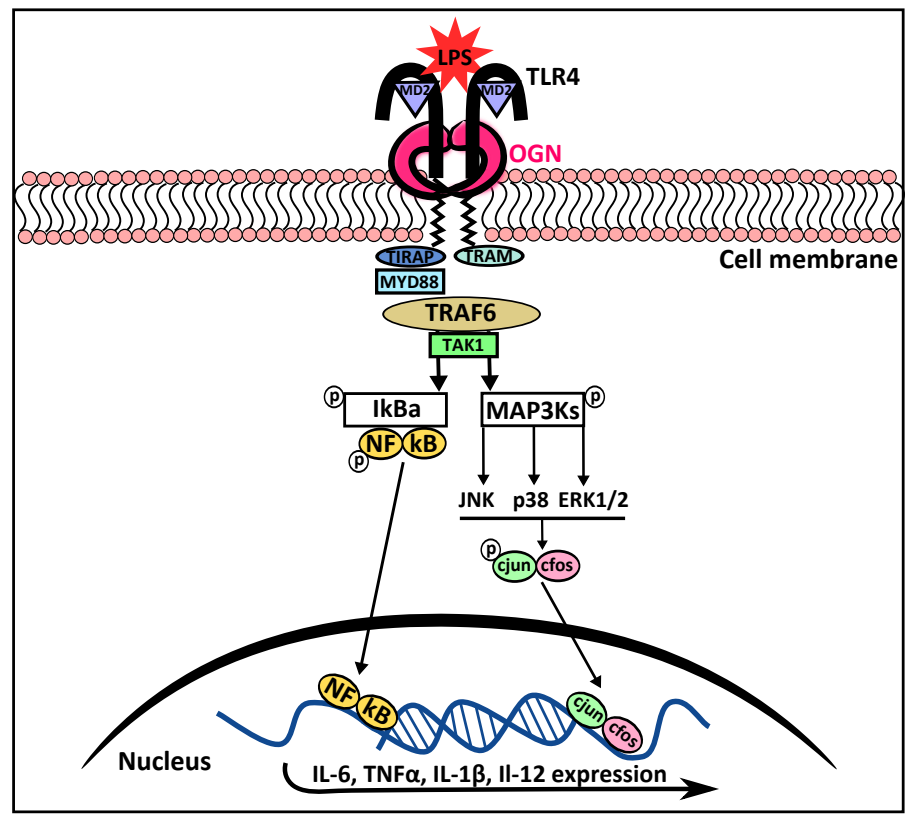

Figure 7 Schematic overview of the proposed iOGN:TLR 4 Signaling Pathway.

TLR4 stimulation with LPS results in receptor dimerization and subsequent high affinity binding of the bridging adaptor molecules TRAM and TIRAP. The bound and activated MyD88 then activates IRAK4, TRAF6, TAK1, and IKK complexes, and TRIF signals through RIP1 to TRAF6/TAK1 and IKK. Both of these pathways result in increased pro-inflammatory cytokine expression. The phosphorylation of MAPKs by TAK1 is enhanced by OGN, resulting in increased $\mathrm{c}$ jun phosphorylation with subsequent nuclear translocation of AP1 (the phosphorylated $\mathrm{c}$ jun/c fos complex), which again resulted in increased pro-inflammatory cytokine expression, reinforcing the inflammatory response ${ }^{53}$. 
Finally, we found that in humans iOGN was expressed on migrated myocardial as well as circulating leukocytes, where expression was found on macrophages but most abundant on a subset of circulating neutrophils. Recent studies have confirmed that rather than being an endstage uniform cell population, neutrophils display a great level of plasticity. Hence, distinct neutrophil phenotypes and/or subsets will develop in response to a wide range of physiological and pathological (e.g. inflammation and infection) conditions ${ }^{51}$. The identification of OGN as a surface marker on approximately $8 \%$ of circulating leukocytes displaying a more proinflammatory phenotype, distinguishes a new specialized neutrophil subset. This observed neutrophil phenotype with accompanying functional characteristics therefore may contribute to the development of inflammatory cardiac diseases, as has been recognized for other neutrophil subsets during disease ${ }^{51,52}$.

In conclusion, we have identified for the first time that SLRP OGN can be glycosylated in multiple ways, resulting in the production a dermatan sulfate glycosylated variant (fOGN) that is associated with fibrosis and a chondroitin sulfate glycosylated membrane-bound variant (iOGN) that is linked to inflammation. This iOGN is present in circulating and cardiac innate immune cells where it boosts TLR4 signaling, as in viral myocarditis and septic shock. 


\section{REFERENCES}

1 Ameye, L. and M.F. Young, Mice deficient in small leucine-rich proteoglycans: novel in vivo models for osteoporosis, osteoarthritis, Ehlers-Danlos syndrome, muscular dystrophy, and corneal diseases. Glycobiology, 2002. 12(9): p. 107R-16R.

Van Aelst, L.N., et al., Osteoglycin prevents cardiac dilatation and dysfunction after myocardial infarction through infarct collagen strengthening. Circ Res, 2015. 116(3): p. 425-36. Rienks, M., et al., Myocardial extracellular matrix: an ever-changing and diverse entity. Circ Res, 2014. 114(5): p. 872-88. Funderburgh, J.L., et al., Mimecan, the 25-kDa corneal keratan sulfate proteoglycan, is a product of the gene producing osteoglycin. J Biol Chem, 1997. 272(44): p. 28089-95. Dunlevy, J.R., et al., Expression of the keratan sulfate proteoglycans lumican, keratocan and osteoglycin/mimecan during chick corneal development. Exp Eye Res, 2000. 70(3): p. 349-62. Yajima, T. and K.U. Knowlton, Viral myocarditis: from the perspective of the virus. Circulation, 2009. 119(19): p. 2615-24. Gheorghiade, M. and R.O. Bonow, Chronic heart failure in the United States: a manifestation of coronary artery disease. Circulation, 1998. 97(3): p. 282-9. Zhang, Y., I-TASSER server for protein 3D structure prediction. BMC Bioinformatics, 2008. 9: p. 40. Roy, A., A. Kucukural, and Y. Zhang, I-TASSER: a unified platform for automated protein structure and function prediction. Nat Protoc, 2010. 5(4): p. 725-38.

Roy, A., J. Yang, and Y. Zhang, COFACTOR: an accurate comparative algorithm for structure-based protein function annotation. Nucleic Acids Res, 2012. 40(Web Server issue): p. W471-7. Macindoe, G., et al., HexServer: an FFT-based protein docking server powered by graphics processors. Nucleic Acids Res, 2010. 38(Web Server issue): p. W445-9.

12 Tasheva, E.S., et al., Mimecan/osteoglycin-deficient mice have collagen fibril abnormalities. Mol Vis, 2002. 8: p. 407-15.

13 Ge, G., et al., Bone morphogenetic protein-1/tolloid-related metalloproteinases process osteoglycin and enhance its ability to regulate collagen fibrillogenesis. J Biol Chem, 2004. 279(40): p. 41626-33. Van Aelst, L.N., et al., Osteoglycin Prevents Cardiac Dilatation and Dysfunction After Myocardial Infarction Through Infarct Collagen Strengthening. Circ Res, 2014.

15 Magnani, J.W. and G.W. Dec, Myocarditis: current trends in diagnosis and treatment. Circulation, 2006. 113(6): p. 876-90.

16 Corsten, M.F., B. Schroen, and S. Heymans, Inflammation in viral myocarditis: friend or foe? Trends Mol Med, 2012. 18(7): p. 426-37.

17 Dai, P., et al., Modulation of TLR signaling by multiple MyD88-interacting partners including leucinerich repeat Fli-I-interacting proteins. Journal of immunology, 2009. 182(6): p. 3450-60. Kemball, C.C., M. Alirezaei, and J.L. Whitton, Type B coxsackieviruses and their interactions with the innate and adaptive immune systems. Future Microbiol, 2010. 5(9): p. 1329-47. Fairweather, D., et al., IL-12 receptor beta 1 and Toll-like receptor 4 increase IL-1 beta- and IL-18associated myocarditis and coxsackievirus replication. J Immunol, 2003. 170(9): p. 4731-7. Zhao, Z., et al., Coxsackievirus B3 induces viral myocarditis by upregulating toll-like receptor 4 expression. Biochemistry. Biokhimiia, 2015. 80(4): p. 455-62.

$21 \mathrm{Li}, \mathrm{H}$., et al., [Roles of cardiac mast cells and Toll-like receptor 4 in viral myocarditis among mice]. Zhongguo dang dai er ke za zhi = Chinese journal of contemporary pediatrics, 2013. 15(10): p. 896902.

Koshiishi, I., T. Hasegawa, and T. Imanari, Quantitative and qualitative alterations of chondroitin/ dermatan sulfates accompanied with development of tubulointerstitial nephritis. Arch Biochem Biophys, 2002. 401(1): p. 38-43. Laurent, G.J., et al., Regulation of matrix turnover: fibroblasts, forces, factors and fibrosis. Biochem Soc Trans, 2007. 35(Pt 4): p. 647-51. Park, H., et al., LRRCE: a leucine-rich repeat cysteine capping motif unique to the chordate lineage. BMC Genomics, 2008. 9: p. 599. Scott, P.G., et al., Crystal structure of the dimeric protein core of decorin, the archetypal small leucinerich repeat proteoglycan. Proc Natl Acad Sci U S A, 2004. 101(44): p. 15633-8. Proszynski, T.J., K. Simons, and M. Bagnat, O-glycosylation as a sorting determinant for cell surface delivery in yeast. Mol Biol Cell, 2004. 15(4): p. 1533-43.

27 Vagin, O., J.A. Kraut, and G. Sachs, Role of N-glycosylation in trafficking of apical membrane proteins in epithelia. Am J Physiol Renal Physiol, 2009. 296(3): p. F459-69. 
Merline, R., et al., Signaling by the matrix proteoglycan decorin controls inflammation and cancer through PDCD4 and MicroRNA-21. Science signaling, 2011. 4(199): p. ra75. Schaefer, L., et al., The matrix component biglycan is proinflammatory and signals through Toll-like receptors 4 and 2 in macrophages. The Journal of clinical investigation, 2005. 115(8): p. 2223-33. Babelova, A., et al., Biglycan, a danger signal that activates the NLRP3 inflammasome via toll-like and P2X receptors. J Biol Chem, 2009. 284(36): p. 24035-48.

Chao, W., Toll-like receptor signaling: a critical modulator of cell survival and ischemic injury in the heart. Am J Physiol Heart Circ Physiol, 2009. 296(1): p. H1-12.

Mann, D.L., The emerging role of innate immunity in the heart and vascular system: for whom the cell tolls. Circ Res, 2011. 108(9): p. 1133-45.

Vallejo, J.G., Role of toll-like receptors in cardiovascular diseases. Clin Sci (Lond), 2011. 121(1): p. 1-10.

Feng, Y. and W. Chao, Toll-like receptors and myocardial inflammation. Int J Inflam, 2011. 2011: p. 170352.

Michelsen, K.S. and M. Arditi, Toll-like receptor signaling and atherosclerosis. Curr Opin Hematol, 2006. 13(3): p. 163-8.

Topkara, V.K., et al., Therapeutic targeting of innate immunity in the failing heart. J Mol Cell Cardiol, 2011. 51(4): p. 594-9.

Reilly, M., et al., Randomized, double-blind, placebo-controlled, dose-escalating phase I, healthy subjects study of intravenous OPN-305, a humanized anti-TLR2 antibody. Clin Pharmacol Ther, 2013. 94(5): p. 593-600.

Riad, A., et al., Toll-like receptor-4 modulates survival by induction of left ventricular remodeling after myocardial infarction in mice. J Immunol, 2008. 180(10): p. 6954-61.

Shimamoto, A., et al., Inhibition of Toll-like receptor 4 with eritoran attenuates myocardial ischemiareperfusion injury. Circulation, 2006. 114(1 Suppl): p. I270-4.

Bennett-Guerrero, E., et al., A phase II, double-blind, placebo-controlled, ascending-dose study of Eritoran (E5564), a lipid A antagonist, in patients undergoing cardiac surgery with cardiopulmonary bypass. Anesth Analg, 2007. 104(2): p. 378-83.

Katsargyris, A., et al., Toll-like receptor modulation: a novel therapeutic strategy in cardiovascular disease? Expert Opin Ther Targets, 2008. 12(11): p. 1329-46.

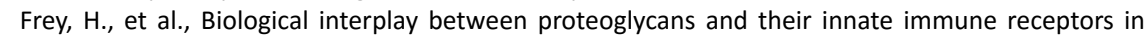
inflammation. FEBS J, 2013. 280(10): p. 2165-79.

Midwood, K., et al., Tenascin-C is an endogenous activator of Toll-like receptor 4 that is essential for maintaining inflammation in arthritic joint disease. Nature medicine, 2009. 15(7): p. 774-80. Johnson, G.B., G.J. Brunn, and J.L. Platt, Cutting edge: an endogenous pathway to systemic inflammatory response syndrome (SIRS)-like reactions through Toll-like receptor 4. Journal of immunology, 2004. 172(1): p. 20-4.

Taylor, K.R. and R.L. Gallo, Glycosaminoglycans and their proteoglycans: host-associated molecular patterns for initiation and modulation of inflammation. FASEB journal : official publication of the Federation of American Societies for Experimental Biology, 2006. 20(1): p. 9-22. Brunn, G.J., et al., Conditional signaling by Toll-like receptor 4. FASEB journal : official publication of the Federation of American Societies for Experimental Biology, 2005. 19(7): p. 872-4. Piccinini, A.M. and K.S. Midwood, DAMPening inflammation by modulating TLR signalling. Mediators Inflamm, 2010. 2010.

Wagner, K.B., S.B. Felix, and A. Riad, Innate immune receptors in heart failure: Side effect or potential therapeutic target? World J Cardiol, 2014. 6(8): p. 791-801.

Rock, K.L., et al., The sterile inflammatory response. Annu Rev Immunol, 2010. 28: p. 321-42. Abston, E.D., et al., Th2 regulation of viral myocarditis in mice: different roles for TLR3 versus TRIF in progression to chronic disease. Clin Dev Immunol, 2012. 2012: p. 129486.

Beyrau, M., J.V. Bodkin, and S. Nourshargh, Neutrophil heterogeneity in health and disease: a revitalized avenue in inflammation and immunity. Open Biol, 2012. 2(11): p. 120134.

Epelman, S., P.P. Liu, and D.L. Mann, Role of innate and adaptive immune mechanisms in cardiac injury and repair. Nat Rev Immunol, 2015. 15(2): p. 117-29. 
s
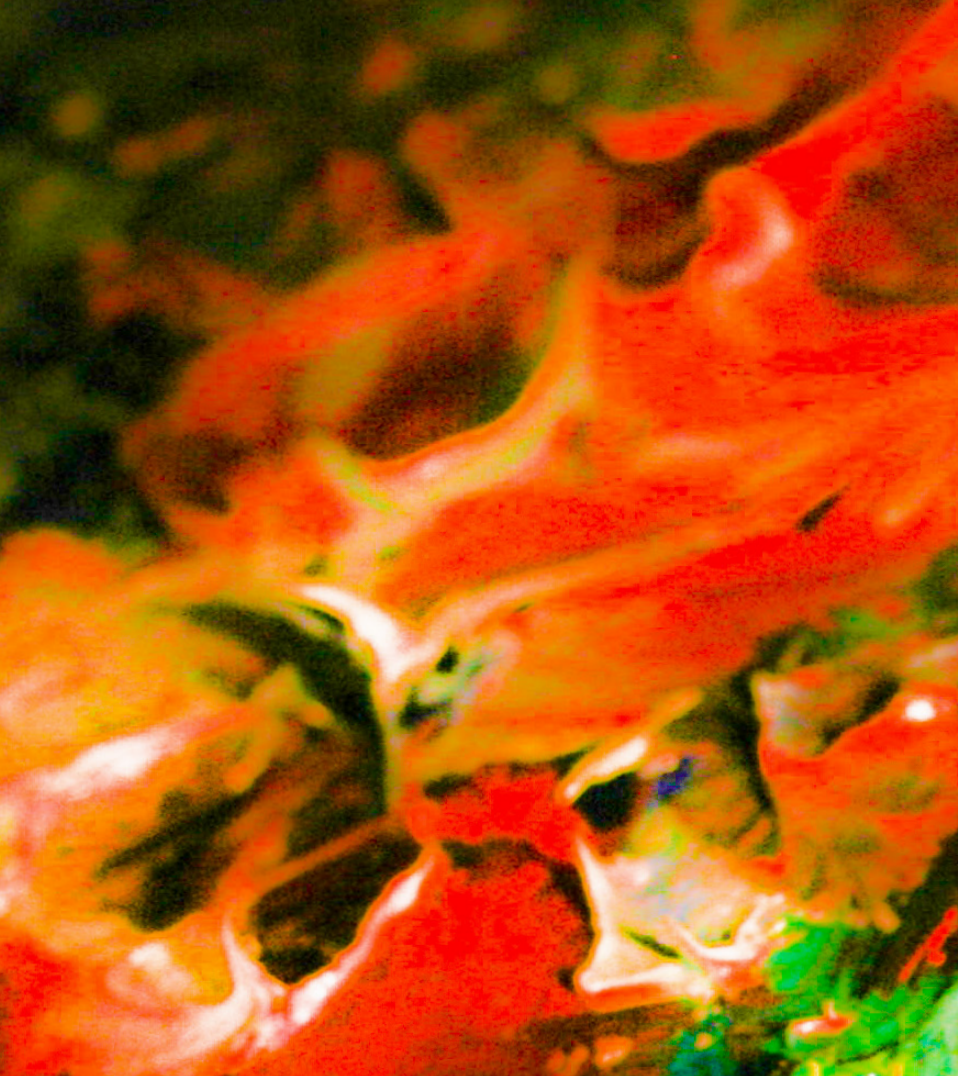

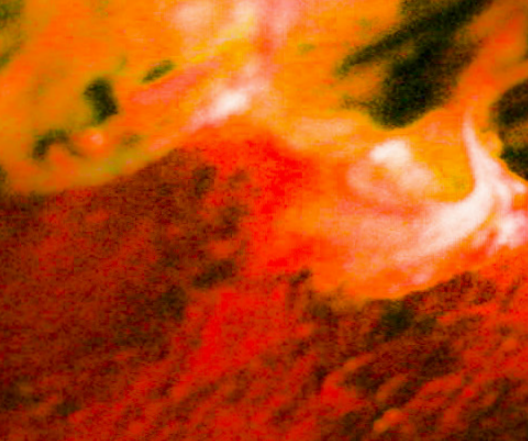
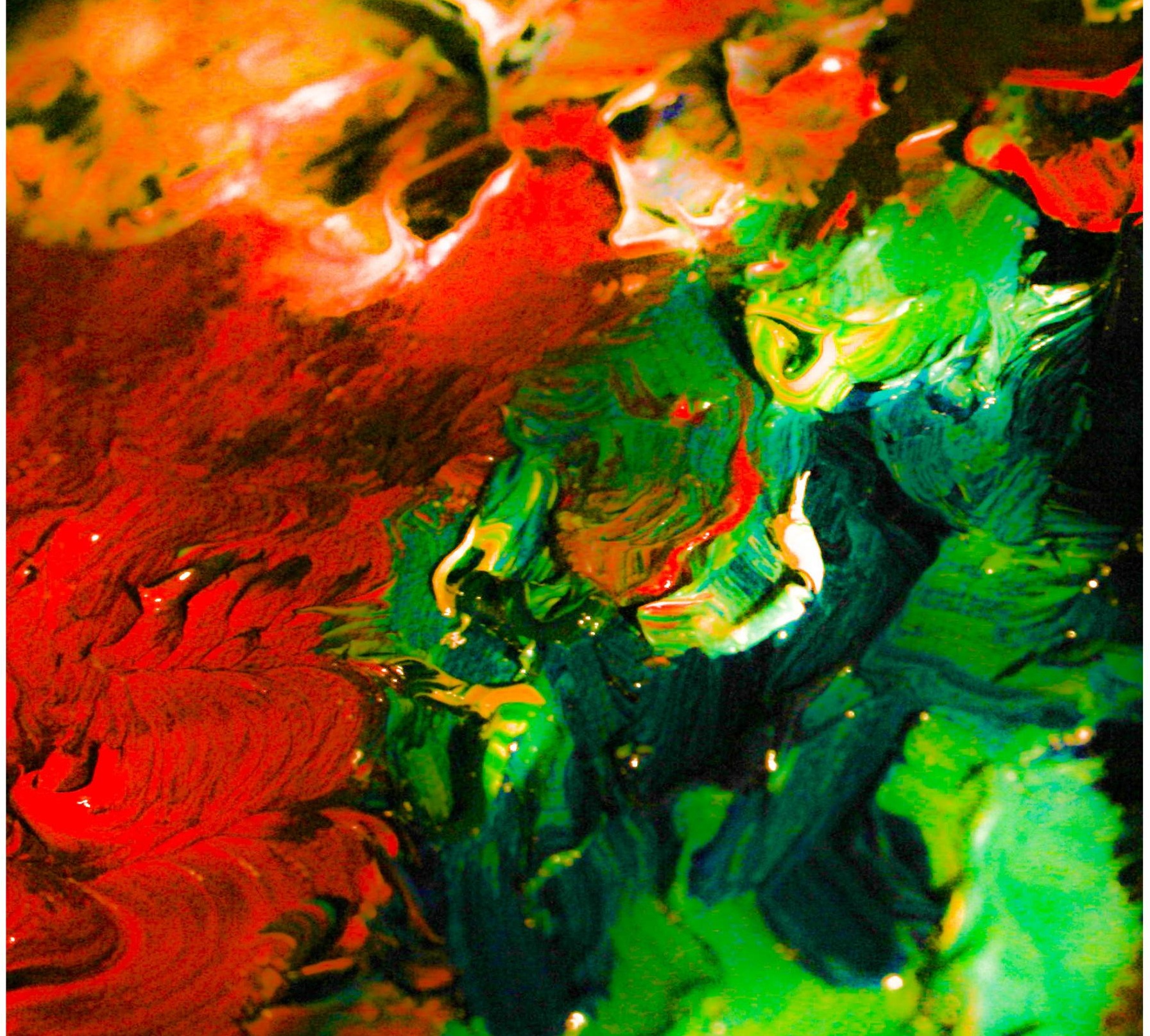
6.
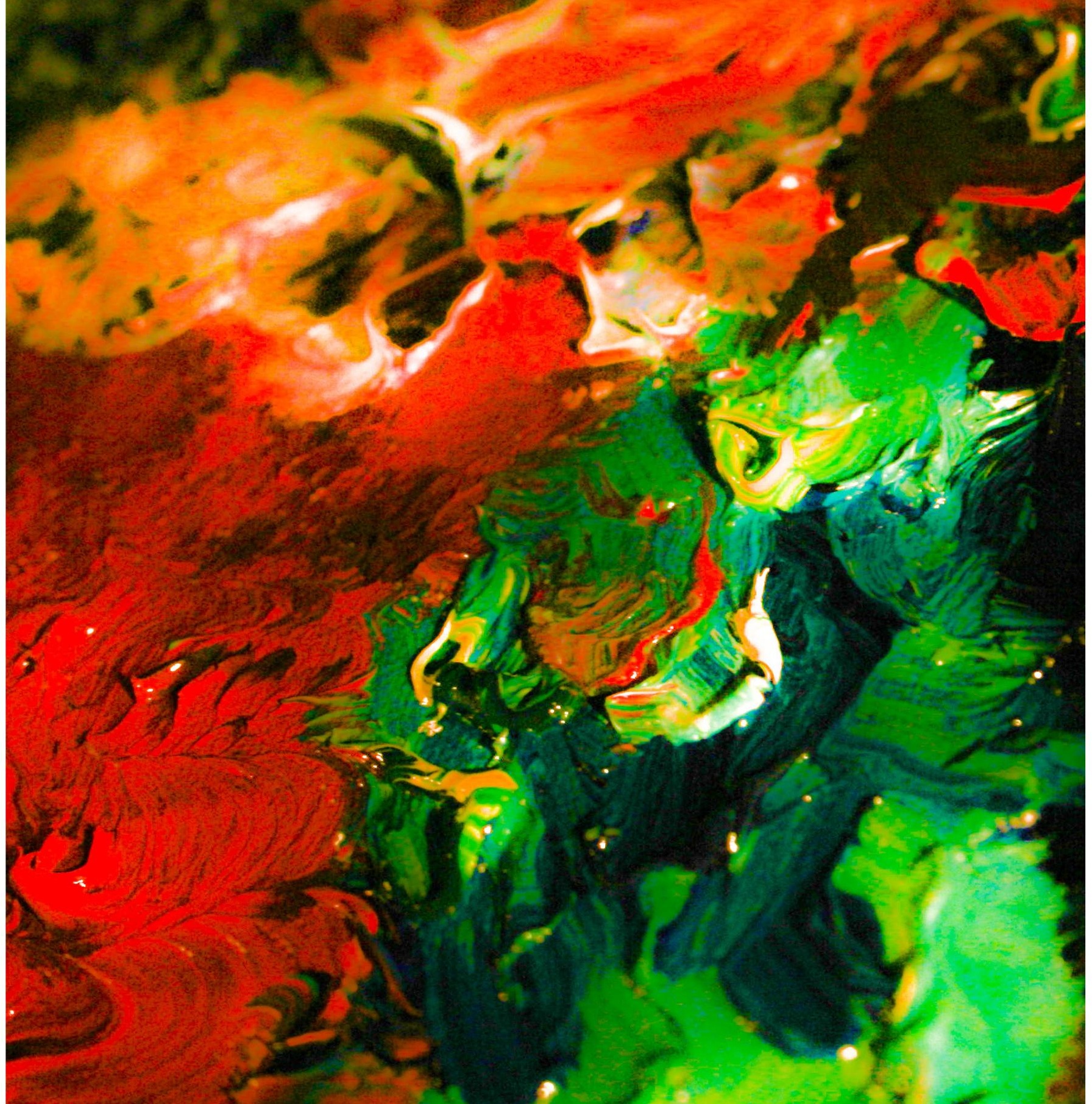

?.

se

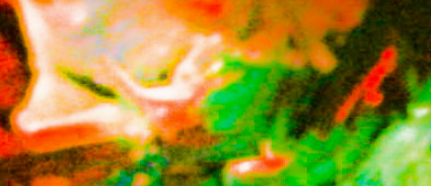

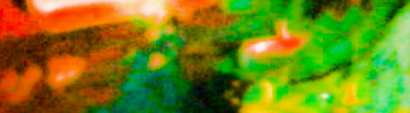

$y^{y}$

Sintas

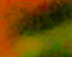

kets 


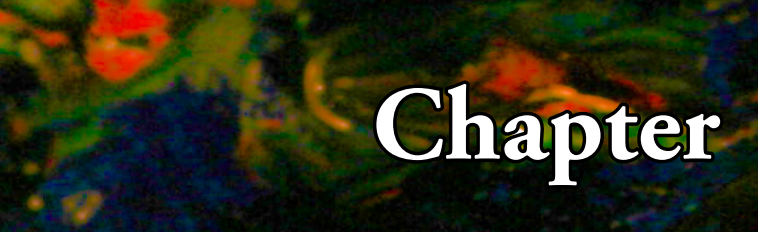

Trie ExTr
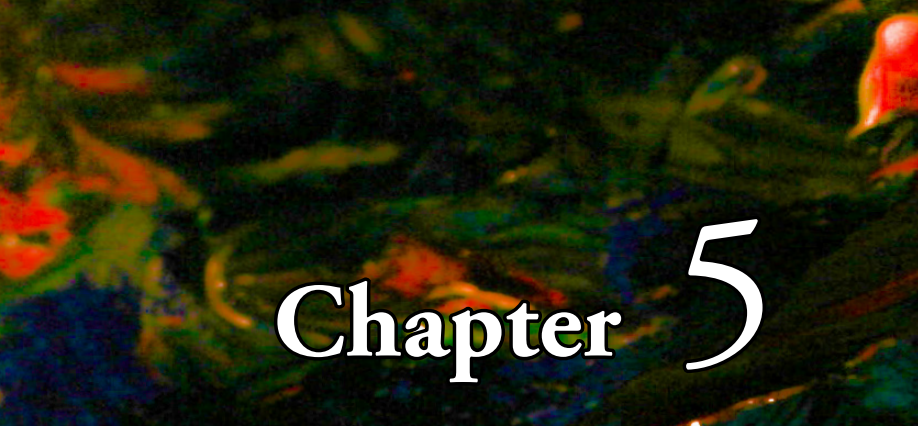

The Extracellular Matrix Protein SPARC is Crucial in Maintaining Endothelial Barrier Function 3
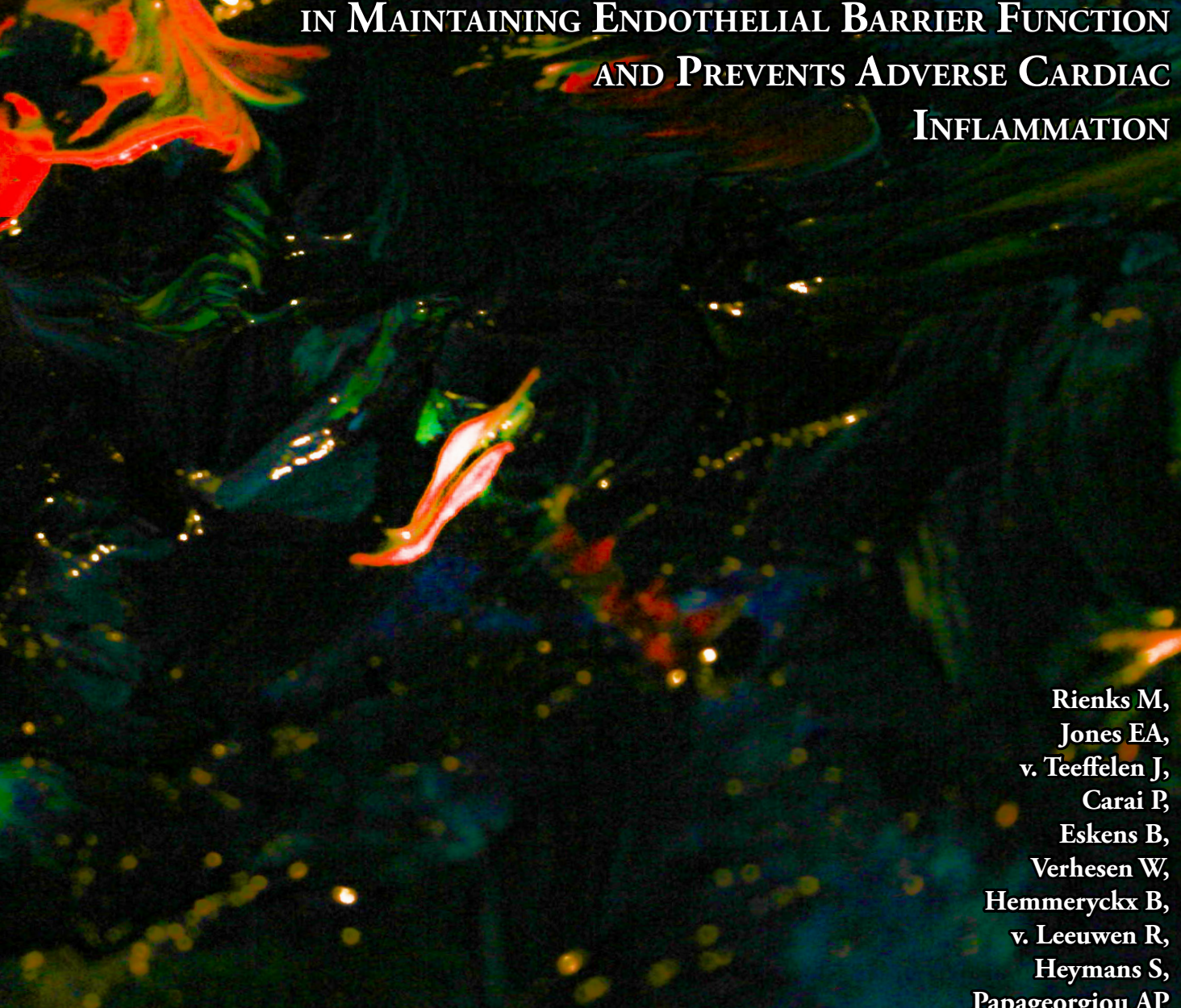

\section{C}




\section{Abstract}

Aims: Viral presence in the heart triggers leukocyte recruitment and pathological remodelling processes leading to ventricular dysfunction. Extracellular non-structural matrix proteins, such as SPARC, are critical regulators of cardiac fibrosis but their role in regulating cardiac inflammation is not well characterised. In this study we investigate the function of SPARC during CoxsackieB3-mediated myocarditis.

Method and Results: In the murine model of myocarditis, absence of SPARC resulted in increased mortality and cardiac inflammation that was reversed after adenovirus-mediated overexpression of SPARC. Intra-vital microscopy of the cremaster muscle showed that SPARC null mice had increased leukocyte adhesion efficacy, decreased leukocyte velocity, and enhanced microvascular permeability. This was also confirmed in the vasculature of the heart. Electron microscopic imaging identified an impaired microvascular endothelial glycocalyx in SPARC null mice. Furthermore, enzymatic digestion of the main glycocalyx components using hyaluronidase resulted in comparable increases in cardiac inflammation during viral myocarditis as well as decreased leukocyte velocity and increased microvascular leakiness. Importantly, systemic administration of recombinant SPARC restored leukocyte velocity and vascular leakiness when the glycocalyx was compromised.

Conclusion: SPARC, and the endothelial glycocalyx, function to limit adverse cardiac inflammation during viral myocarditis. SPARC is a targetable component of the glycocalyx, reducing leukocyte adhesion and restoring endothelial barrier function. 


\section{INTRODUCTION}

Cardiotropic viruses, such as the entero-coxsackie B viruses, induce severe cardiac inflammation in susceptible patients resulting in cardiac dysfunction and possibly sudden death. This form of heart disease is particularly devastating as it affects previously healthy young adults. Though in some cases the cardiac inflammation resolves itself, in approximately a third of patients the acute inflammatory phase can transition into chronic inflammation, triggering cardiomyocyte death, decreased cardiac function and eventually heart failure ${ }^{1}$. Elucidating the underlying mechanisms of enhanced or sustained cardiac inflammation can facilitate the development of new specific therapies for viral myocarditis, which are currently still lacking.

Matricellular proteins (MCPs) are a group of non-structural proteins that are present in the ECM and modulate cellular function. Their expression is low during normal postnatal life but is dramatically up regulated upon tissue injury, where they bind to cell surface receptors, growth factors, cytokines and proteases ${ }^{2}$. SPARCs main biological function has been attributed to fibroblast function in connective tissue ${ }^{3-6}$ but there are well-described functions for SPARC during tumour development ${ }^{7,8}$ and angiogenesis ${ }^{9}$. The recruitment of leukocytes to the site of injury is a co-ordinated process that requires interactions of leukocytes and the endothelium as well as reorganisation of the endothelial cell cytoskeleton ${ }^{10}$. Though certain matricellular proteins have been recognized for regulating cardiac inflammation ${ }^{11}$, whether-and how-SPARC is needed for in vivo cardiac leukocyte recruitment is unknown. The aim of the present study was to investigate how SPARC regulates pathological inflammation, in particular during virus-induced myocarditis.

\section{Material and Methods}

\section{Animals}

C57Bl6/J male and female mice SPARC-KO (backcrossed 10 times) and WT C57Bl6/J mice (Harlan, the Netherlands between 10-18 weeks of age were used. Mice were maintained in specific pathogen-free facilities at Maastricht or Leuven University. The Animal Care and Use Committee of the University of Maastricht and Leuven approved all described study protocols, according to the Dutch and Belgian law.

\section{Murine CVB3 Induced Viral Myocarditis Model}

Eight to 12-week old inbred C57B16/J SPARC-KO and WT mice were infected with a SPARC adenoviral overexpressing vector or R5 control vector ${ }^{12} 7$ days before the mice were inoculated intra-peritoneal (i.p.) with $1 \times 107$ cell culture $50 \%$ infective dose (CCID50) of CVB3 (Nancy Strain). For long-term administration ( 5 weeks) mice received SPARC via osmotic minipump. Mice received hyaluronidase (iv 70U) ${ }^{13}$ one hour prior to CVB3. All animals were anaesthetized with an intra-peritoneal injection of Xylazine $(10 \mathrm{mg} / \mathrm{kg})$ and Ketamine $(100 \mathrm{mg} / \mathrm{kg})$ and sacrificed by cervical dislocation. Troponin was measured using a high sensitivity ELISA (Roche Diagnostics).

\section{Mouse Cremaster Preparation and Intravital Microscopy}

Mice were anesthetized and the exposed muscle was positioned on a clear Silicon pedestal and longitudinally incised from the apex to the inguinal canal with minimal disruption of the 
vascular supply. The stage of the intravital microscope (Olympus BHM) was coupled to a cooled intensified CCD video camera (GenIV ICCD, Princeton Instruments). Cremaster muscle capillaries were examined with a water immersion objective lens (Olympus; LUMPlanFL, NA 0.9). The muscle was continuously $(5 \mathrm{ml} / \mathrm{min})$ superfused at $37^{\circ} \mathrm{C}$ with a bicarbonate-buffered physiological salt solution (PSS). Texas Red labeled $40 \mathrm{kDa}$ dextrans (Dex-40; Invitrogen) were intravenously injected at $10 \mathrm{mg} / \mathrm{ml}$ in PBS. Cremaster capillaries of $30-50 \mu \mathrm{m}$ were chosen for examination from different microscopic field, and recorded on videotape using trans and epiillumination. After baseline recordings were made (15-20 min) TNF $\alpha$ ( $2 \mathrm{ng} / \mathrm{ml}$; Peprotech) was dropped on the Cremaster muscle for 5 minutes. Recordings of the same capillaries were made at baseline, after 60 and 120 minutes. $0.1 \mathrm{ml}$ recombinant SPARC $(15$ microgram $/ \mathrm{kg}, \mathrm{R}$ and D systems) was injected i.v at a concentration of $0,15 \mathrm{mg} / \mathrm{kg}$ prior to TNF $\alpha$ stimulation. 0.1 $\mathrm{ml}(35 \mathrm{U})$ of hyaluronidase was injected after the equilibration period and SPARC was injected 10 minutes after the injection of hyaluronidase. Rolling leukocytes were measured by counting the visible passing leukocytes for 60 seconds. Counting cells that adhered to the vessel wall for $\geq 30$ seconds and did not move more than their own diameter in distance across the vessel wall during this period qualified as adherent leukocytes. Adhesion efficacy could be calculated by dividing the number of adherent leukocytes by the total number of rolling leukocytes. Leukocyte velocities were determined by measuring the time it took individual cells to travel $150 \mathrm{um}$ in distance. Only cells that were visible during the entire course were included $(15$ cells per vessel with 5 vessels per mouse). Hokawo 2.5 Wasabi Software and Image J 1.48v were used for post-hoc data analysis.

\section{GLycocalyx Measurements}

The lateral thigh muscle of C57B16/J SPARC-KO and WT mice was prepared for side stream dark-field imaging. The perfused boundary region (PBR) was measured using the GlycoCheck Measurement Software ${ }^{14}$. Extrapolated glycocalyx thickness is the inverse \% PBR of WT mice; increases in PBR represent deeper penetration of erythrocytes into the glycocalyx.

\section{CARDIAC FRACTIONATION AND FLOW CYTOMETRY}

Peripheral blood and the cardiac immune cell fractions were analysed using a FACS CantoII flow cytometer (Becton Dickenson (BD), San Diego, CA). Cells were first incubated with anti-CD16/32 (eBioscience, San Diego, CA) to block Fc receptor binding. CD45+ leukocytes subpopulations were defined as follows: T lymphocytes (CD3+), B lymphocytes (B220+), Granulocytes (CD11b+ Ly6G+), Monocytes (CD11b+ F4/80-). Absolute counts for cardiac and blood samples were determined with $\mathrm{BD}$ Truecount ${ }^{\mathrm{TM}}$ tubes according to the manufacturer's instructions.

\section{STAINING AND IMMUNOHISTOCHEMISTRY}

$4 \mu \mathrm{m}$ thick sections were stained with CD45 (BD Pharmingen) and CD3 (Thermo Scientific) for determining the amount of inflammation. Immunofluorescence of paraffin sections was performed according to protocol using antibodies against CD45 (BD Pharmingen), CD31 (BD Pharmingen), VCAM-1 (BD Pharmingen) and SPARC (R\&D). Images were acquired using Leica Qwin image processing software (Leica, Germany).

\section{T-CELL ASSAYS}

Spleen cells were sorted with an Aria II Sorter using the following antibodies CD11b, CD11c, CD19, CD4, CD8, CD25 (e-biosciences). Populations were defined as follows CD4+ 
cells (CD11b-, CD11c-, CD19-, CD4+, CD8-, CD25-) and CD8+ cells (CD11b-, CD11c-, CD19-, CD4-, CD8+, CD25-). Cells were incubated at different concentration with CD8/ $\mathrm{CD} 28$ beads (DynaBeads, Invitrogen) for $72 \mathrm{hrs}$ at $37^{\circ} \mathrm{C}$ alone or in the presence of sorted CD4+ CD25+ T regulatory cells, before undergoing FACS analysis.

\section{ELECTRON MiCROSCOPY}

Hearts were fixed by perfusing $5-10 \mathrm{ml}$ of Glutaraldehyde $2,5 \%$, Saccharose $12 \%, \mathrm{Na}$ cacodylate $3 \mathrm{H} 2 \mathrm{O} 0,4 \mathrm{M} \mathrm{pH} 7,3$, lanthanum 4\% pH 7,4 after which they were sectioned into small cubes that were fixed for another 2 hours. Samples were dehydrated in graded series of ethanol and embedded in Araldite (CY-212; Serva). Ultrathin sections were counterstained with uranium acetate and lead citrate prior to examination in a Philips CM100 electron microscope.

\section{REAL TIME PCR}

Real-time reverse transcriptase-polymerase chain reaction (RT-PCR) analysis was performed (Bio-Rad, Maastricht, Netherlands) to determine transcript with the following primers; iNOS (FWD GCA-GCG-GCT-CCA-TGA-CTC-CC, BWD AGG-TGG-TCC-TCC-TCC-GGGTG), CD68 (FWD CCA-GCT-GTT-CAC-CTT-GAC-CT, BWD CAA-TGA-TGA-GAGGCA-GCA-AG), Arginase1 (FWD CAA-GAC-AGG-GCT-CCT-TTC-AG, BWD GCTTAT-GGT-TAC-CCT-CCC-GT), U6 (FWD CGC-TTC-GGC-AGC-ACA-TAT-AC, BWD TTC-ACG-AAT-TTG-CGT-GTC-AT), MDA5 (FWD GCC-TGG-AAC-GTA-GAC-GACAT, BWD TTG-GGC-CAC-TTC-CAT-TTG-GT), RIG-1 (FWD AGA-CGG-TTC-ACCGCA-TAC-AG, BWD AAG-CGT-CTC-CAA-GGA-CAG-TG), CVB3 (FWD ACG-AATCCC-AGT-GTG-TTT-TGG， BWD TGC-TCA-AAA-ACG-GTA-TGG-ACA-T)，TLR3 (FWD AGC-ATC-AAA-AGA-AGC-CGA-AA, BWD CTT-GCT-GAA-CTG-CGT-GATGT). Data were acquired and analyzed IQ5 software (Bio-Rad, Maastricht, Netherlands).

\section{AdHesion Assay}

Endothelial cells were seeded on $\mu$-slide VI0.4 (Ibidi, Planegg, Germany) and then stimulated with TNF $\alpha$ for 24 hours. Blood was isolate from mice and the red blood cells were lysed to produce a mixed leukocyte population prior to staining with CFSE. Endothelial cells were exposed to leukocytes under shear as previously described ${ }^{15}$.

\section{Vascular Permeability Assay}

Evans Blue and bead extravasation experiments were performed as previously described ${ }^{16}$, ${ }^{17}$. Briefly, a 1:10 dilution of red fluorescent microbeads (Invitrogen, Fluospheres) was tail vein injected. The beads were allowed to circulate for 2 minutes, before intracardiac perfusion of $1 \%$ PFA for 15 minutes. Heart were then dissected, further fixed for 1 hour in 1\% PFA, cryoembedded, sectioned and then immunostained for VE-Cadherin (R\&D Systems). Sections were imaged using z-sectioning on a confocal Zeiss LSM700.

\section{ECHOCARDIOGRAPHIC AND ELECTROCARDIOGRAM RECORDINGS}

Animals were anesthetized and placed in a supine position on a heating pad to keep the internal body temperature between $37.5-37.7^{\circ} \mathrm{C}$ by using a rectal probe. Standard views were obtained in 2-D as well as M-mode by transthoracic echocardiography using a $12 \mathrm{MHz}$ probe (Hewlett Packard, Amsterdam, the Netherlands) on a Visual Sonics echocardiograph. For 
electrocardiogram recordings, needle electrodes were inserted under the skin in axillary and inguinal positions. When the temperature was stable, an ECG was recorded for $1 \mathrm{~min}$ using the Powerlab 16/35 equipped with a 16 channel bioelectric amplifier (AD Instruments, United Kingdom), and 10 beat measurements of routine ECG parameters, such as RR interval, heart rate, PR interval, QRS interval, QT (normal and Fridericia corrected = QTc) interval and JT interval duration, Tpeak-Tend, and the amplitudes of the $\mathrm{R}$ and $\mathrm{T}$ wave, were performed with Labchart Pro Version 8 (AD Instruments).

\section{Statistical Analysis}

Results represent the mean \pm SD unless indicated otherwise. For murine studies, D'Agostino and Pearson's omnibus normality test was performed. Statistical significance was determined by unpaired Student's t test or ANOVA when data was normally distributed. Wilcoxon, MannWhitney or Kruskal-Wallis test was used for non-parametric data as indicated. Gehan-BreslowWilcoxon or Mantel-Cox test was used for survival analysis. Statistical analyses were performed with Prism GraphPad software v5.0 (* $\mathrm{p}<0.05),\left({ }^{* *} \mathrm{p}<0.005\right),\left({ }^{* * *} \mathrm{p}<0.0001\right)$.

\section{RESUlts}

Absence of SPARC Increases Cardiac Inflammation during Viral Myocarditis.

SPARC expression in WT hearts, assessed by immunohistochemistry and immunoblotting, initially decreased 5 days after human coxsackie B3 virus (CVB3) injection, but then increased significantly at 11 days (Figure 1A-C). Absence of SPARC led to increased mortality (7/12 in KO vs. 4/14 in WT at 7 days; $\mathrm{p}=0.06$ ) (Figure 1D) but did not alter the viral replication cycle of CVB3, as cardiac levels did not significantly differ during the onset of cardiac viral infection at days 2(Figure 1E). Viral levels were not significantly altered in the KO as compared to WT mice at peak viremia (day 5) in either the heart or the spleen, nor were there difference in the expression of virus recognition receptors TLR3, RIG-1 and MDA-5 (supplemental figure 1). However SPARC null mice had more cardiac infiltration as indicated by H\&E staining and a higher amount of CD45+ leukocytes present in the heart as compared to WT mice at day $7(0.7 \pm 0.2 \%$ vs $6.8 \pm 1.8 \%$ for WT and KO respectively; $\mathrm{p}<0.005$ (Figure $1 \mathrm{~F}-\mathrm{G}$ ). Adenovirus mediated overexpression of SPARC, significantly reduced the CD45+ leukocyte infiltration in SPARC null mice to $1.5 \pm 0.3 \%$ (Figure $1 \mathrm{G}$ ) almost to WT levels. Circulating troponin levels increased significantly following CVB3 administration in KO and WT mice but was not changed with SPARC overexpression (Figure 1H). In order to explore the long-term effect of SPARC loss on cardiac function after viral myocarditis, SPARC KO and WT mice underwent echocardiographic assessments at 4 days, 5-weeks and 9 weeks after viral infection (Table 1). Concomitantly a group of KO and WT mice received SPARC systemically for 5 weeks and also underwent echocardiographic evaluation at 4 days and 5 weeks (Table 1). Survival was lower during first 5 weeks in the KO mice $(9 / 21,43 \%)$ as compared to WT mice $(11 / 14,72 \%)$ and dilated cardiomyopathy only occurring in the KO mice at 9 weeks $(\mathrm{p}=0.02$ and $\mathrm{p}=0.04$, for fractional shortening and left ventricular systolic dimension respectively). Interestingly in the surviving mice at 9 weeks the incidence of conductance abnormalities observed in an ECG were higher in the WT than in the KO mice (Table 1, supplemental Figure 3). Though SPARC administration did not affect the cardiac function or cardiac dimension in both WT and KO mice at 5 weeks it did significantly improve the survival of KO mice $(14 / 15, \mathrm{p}=0.009)$. 


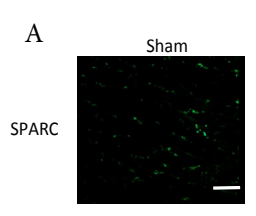

$\mathrm{D}$

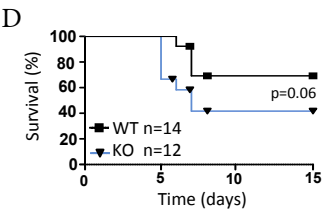

E
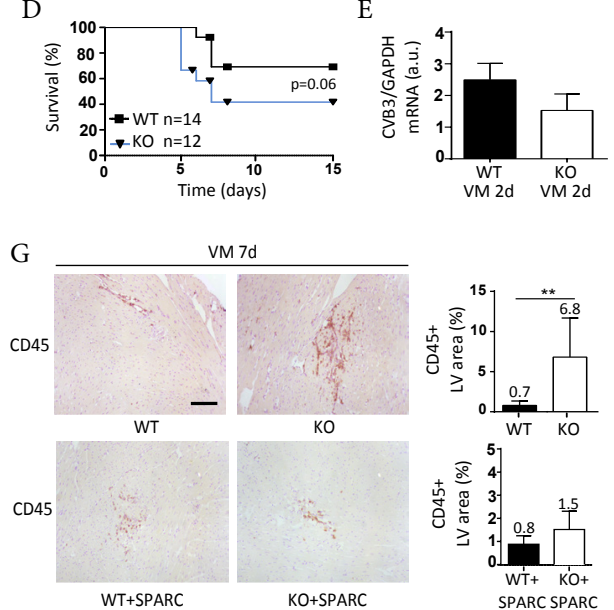

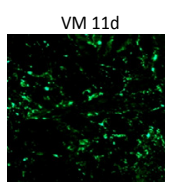

VM 2d VM 2d
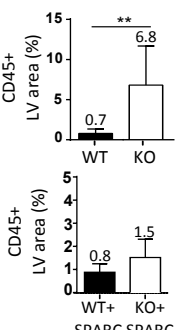

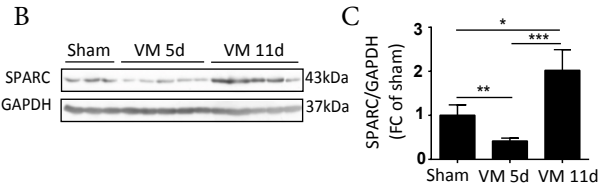

$\mathrm{F}$
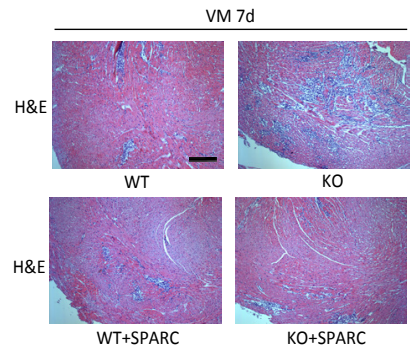

$\mathrm{H}$

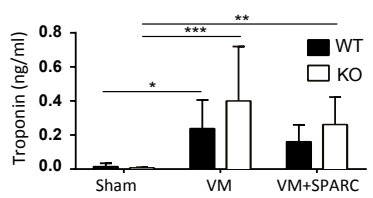

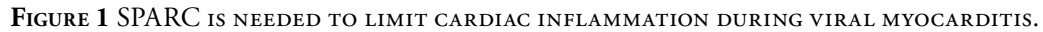

(A) SPARC expression initially decreases after CVB3 infection but then increases significantly $(\mathrm{n}=3)$. (B) Western blot analysis confirms the biphasic response in SPARC levels during viral myocarditis. (C) Quantification of SPARC protein levels $\left(\mathrm{n}=3,4,5\right.$ respectively; $\left.{ }^{*} \mathrm{p}=0.01,{ }^{* *} \mathrm{p}=0.005,{ }^{* * *} \mathrm{p}=0.0007\right)$. (D) Survival of SPARC null and WT animals during CVB3 infection (mortality: 7/12 in SPARC null versus 4/14 in WT, p=0.06). (E) Cardiac CVB3 levels are similar in both genotypes $(\mathrm{n}=4)$. (F) H\&E staining showing difference in myocyte necrosis and cellular infiltration between WT and KO animals. (G) CD45 staining and quantification of left ventricular sections 7 days after CVB3 injection showing increased cardiac leukocytes in SPARC KO hearts $\left({ }^{* *} \mathrm{p}=0.004, \mathrm{n} \geq 10\right.$ per group). Adenoviral overexpression of SPARC in null mice significantly reduced the amount of CD45+ infiltration in the heart $(n \geq 7$ per group). (H) ELISA for serum troponin levels revealed increased troponin levels in response to viral exposure without any difference between both genotypes $\left(\mathrm{n}=4,7,6\right.$ respectively; $\left.{ }^{*} \mathrm{p}=0.04,{ }^{* *}=0.01,{ }^{* * *} 0.0005\right)$ All images shown are representative, Scale bar: $200 \mu \mathrm{m}$.

\section{SPARC Regulates Leukocyte Recruitment during Viral Myocarditis but does not Directly Control Leukocyte Proliferation or Adhesion.}

FACS analysis of circulating leukocytes showed no changes between SPARC WT and null mice in the amount or distribution of leukocytes either at baseline (Figure 2A) or after CVB3 infection (Figure 2B). However, FACS analysis of the cardiac leukocyte population 4 days post infection, when there is onset of inflammation but when mortality is not yet observed, confirmed a rapid recruitment of innate immune cells in mice lacking SPARC (Figure 2C-D). The absolute amount of monocytes and granulocyte populations in the heart were significantly higher in SPARC KO as compared to baseline, which was not the case for WT mice $(\mathrm{p}<0.05$, Figure $2 \mathrm{C}$ and $2 \mathrm{D}$, respectively). CVB3 infection resulted in a concomitant increase in the cardiac CD3+ lymphocytic presence at day $7(\mathrm{p}=0.08,10$ vs 22 cells per $\mathrm{mm} 2$ for WT and SPARC null mice respectively, Supplemental Fig.2A). Though the absence of SPARC affected the CD3 infiltrate in the heart in vivo, SPARC null CD4+ or CD8+ lymphocytes were equally distributed as demonstrated by FACS analysis of the leukocyte fraction (Figure 2E). In vitro splenic KO lymphocytes proliferated equally well as WT cells and the suppressive capacity of T-regulatory cells was comparable (Supplemental Fig.2B). Nor was there a difference in 
the relative amount of M1 and M2 markers between KO and WT mice in the heart at day 7 (Supplemental Fig. 2C-D). Finally in order to assess whether SPARC absence affects the adhesion of leukocytes to endothelial cells, we performed in vitro adhesion assay under static conditions and under flow. Freshly isolated leukocytes from KO and WT mice adhered equally well to TNF $\alpha$ stimulated cardiac microvascular endothelial cells (Figure 2F-G).

A

B

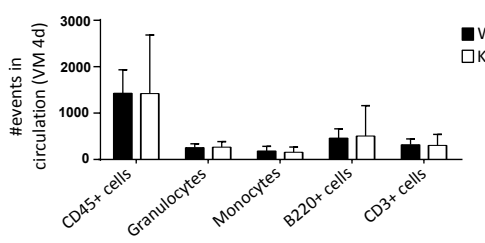

C

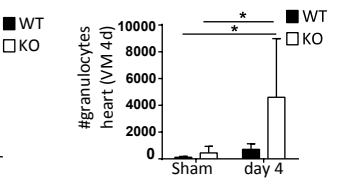

$\mathrm{D}$

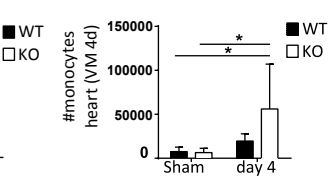

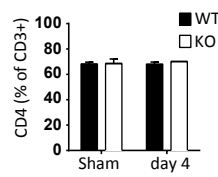

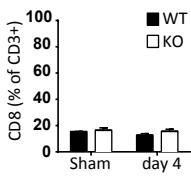

$\mathrm{F}$

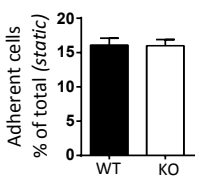

G

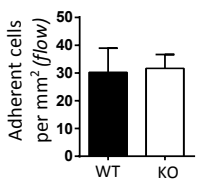

Figure 2 Absence of SPARC results in faster leukocyte recruitment to the heart.

(A) FACS analysis of circulating leukocytes (CD45), monocytes, granulocytes, and lymphocyte populations shows no differences between SPARC null and WT mice at baseline or (B) 4 days after injection with CVB3 ( $\mathrm{n} \geq 5$ per group). (C) Cardiac monocytes and (D) granulocytes were significantly increased in the SPARC null mice though not in the WT mice, 4 days after CVB3 infection ( $\left.{ }^{*} \mathrm{p} \leq 0.01 ; \mathrm{n} \geq 5\right)$. (E) The percentage of CD4 and CD8 T-lymphocytes did not differ between WT and KO mice ( $\mathrm{n}=4$ per group). (F-G) Furthermore, neither static nor flow adherence of WT versus KO leukocytes differed ( $n=3$ per group for flow, $n=5$ per group for static).

\section{SPARC Modulates Leukocyte Adhesion and Endothelial Barrier Integrity.}

In order to further elaborate on how SPARC affects leukocyte recruitment in vivo, we performed intra-vital microscopy of the microvasculature in the cremaster muscle. This allows the visualization of the microvessels and can be used for the assessment of leukocyte adherence, rolling and velocity ${ }^{18}$ (Figure 3A-B). Lack of SPARC did not affect the number of adherent cells itself (Figure 3C), though the number of rolling leukocytes after TNF $\alpha$ was reduced (Figure 3D). The adhesion efficacy - seen as the percentage of adhering cells over total rolling cells ${ }^{19}$ - was significantly increased in SPARC null mice, with a 8.6-fold increase in SPARC null mice versus a 4-fold increase in SPARC WT mice after TNF $\alpha$ stimulation $(\mathrm{p}<0.05)$ (Figure 3E). Furthermore, TNF $\alpha$ stimulation reduced the velocities of individual leukocytes in WT mice $(\mathrm{p}<0.0001$, Figure $3 \mathrm{~F}-\mathrm{G})$. Leukocyte velocities were also significantly reduced in SPARC null mice as compared to WT both at baseline ( $<<0.0001$, Figure $3 \mathrm{~F}$ ) and further reduced after $\mathrm{TNF} \alpha$ stimulation ( $\mathrm{p}<0.001$, Figure $3 \mathrm{G}$ ). Importantly, injection of recombinant SPARC restored the observed alterations in the SPARC null mice, both at baseline and upon $\mathrm{TNF} \alpha$ stimulation $(\mathrm{p}<0.0001)$.

\section{SPARC is Present in the Endothelial Glycocalyx.}

SPARC co-stained with the endothelium specific proteins CD31 and VCAM-1 in CVB3infected hearts (Figure 4A). Furthermore it co-localized with Wheat Germ Agglutinin, staining lectins of the microvasculature and did not co-localize on CD45+ leukocytes. The glycocalyx, which consists of proteoglycans, glycoproteins and glycolipids, regulates vascular permeability 
and hence plays a central role in modulating the influx of inflammatory cells under homeostasis as well as pathophysiological conditions ${ }^{20-22}$. Electron microscopy of the glycocalyx revealed either absence or a severely damaged glycocalyx of both capillaries and arterioles in the heart of KO mice, whilst a normal glycocalyx was visible in their WT littermates (Figure 4B). The defect in endothelial glycocalyx composition in SPARC null animals was confirmed Using GlycoCheck Measurement Software ( $<<0.05$, Figure 4C). Finally, SPARC was detected in a pull down of cardiac endothelial cells using heparin-sepharose beads (Figure 4D), confirming the expression of SPARC in cardiac endothelial cells and the interaction between SPARC and heparan sulfates, a characteristic of glycocalyx components ${ }^{23,24}$.

$\bar{A}$

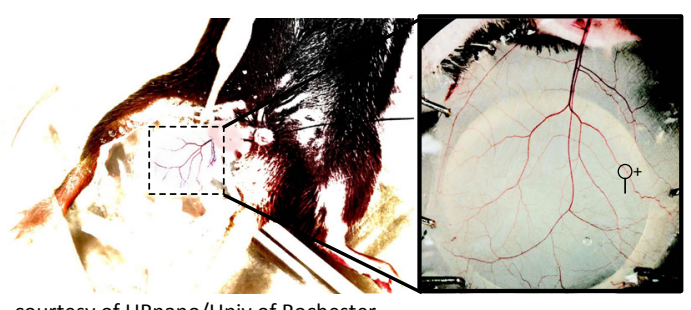

courtesy of URnano/Univ of Rochester
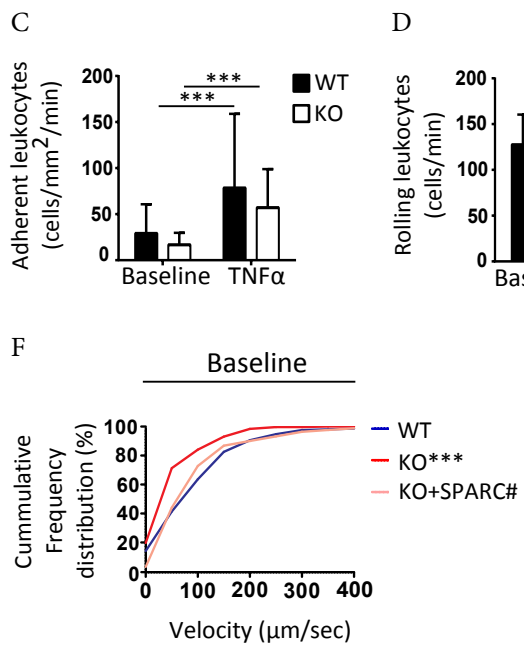

B

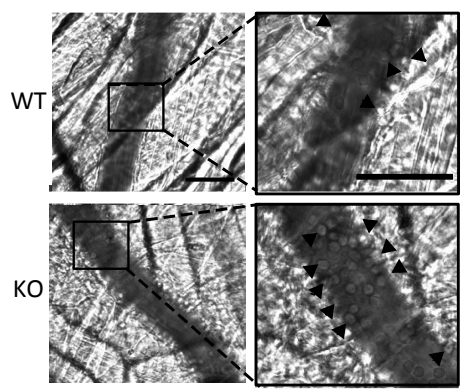

$\mathrm{E}$

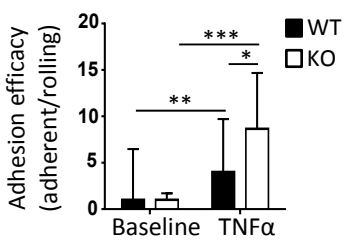

G

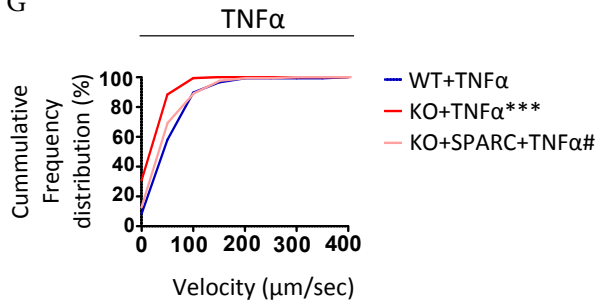

Figure 3 AbSenCE of SPARC RESUlts in inCREASEd LeUKoCyte-endothelial interaCtions.

(A) Using intra-vital microscopy of the cremaster muscle, the number of adherent leukocytes (B), was measure in SPARC null and WT animals. (C) No differences were observed in the number of adherent cells (D) though a significantly lower amount of leukocytes were rolling in the SPARC KO mice. (E) Adhesion efficacy, calculated by dividing the number of adherent leukocytes by total rolling leukocytes, was significantly higher in SPARC KO animals. (F) Cumulative frequency distribution of leukocyte velocities show significant differences between the 3 groups before and after $(\mathrm{G}) \mathrm{TNF} \alpha\left(\mathrm{KO}\right.$ vs WT ${ }^{* * *} \mathrm{p}=0.0001 ; \mathrm{KO}+\mathrm{SPARC}$ vs $\left.\mathrm{KO} \# \mathrm{p}=0.0003\right)$. 
$\bar{A}$

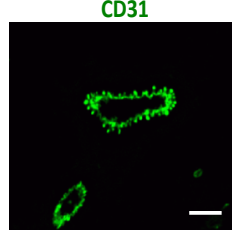

VCAM-1

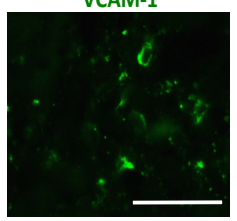

WGA

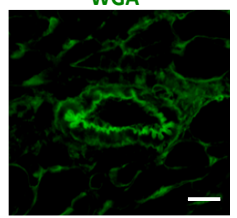

CD45

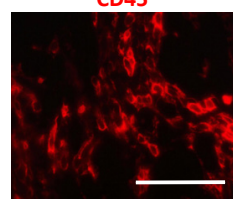

SPARC

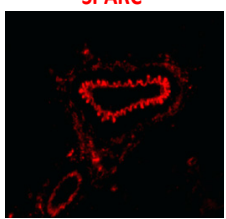

SPARC

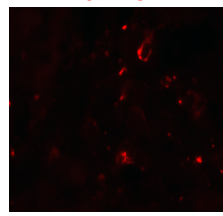

SPARC

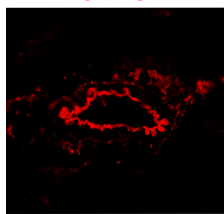

SPARC

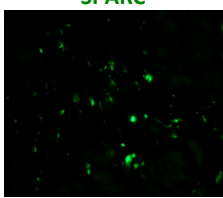

CD31 SPARC

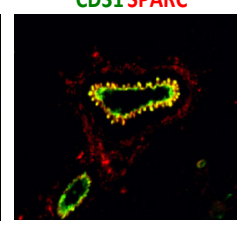

VCAM-1SPARC

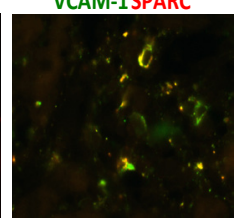

WGA SPARC

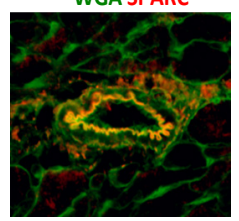

CD45 SPARC

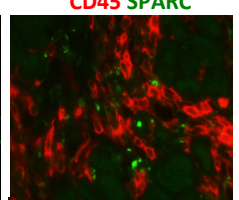

$\overline{\mathrm{B}}$
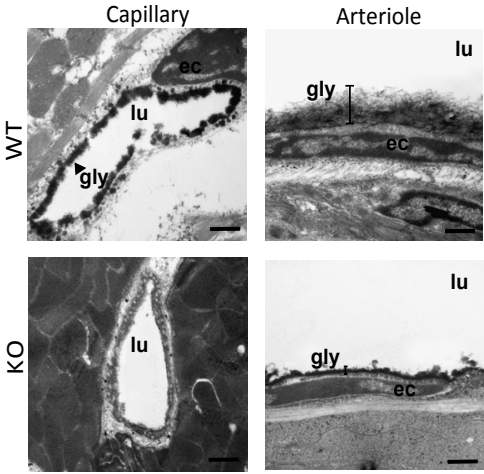

Iu

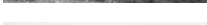

lu

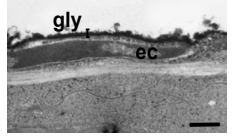

C

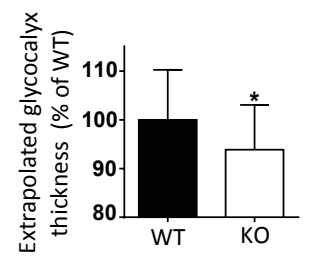

D

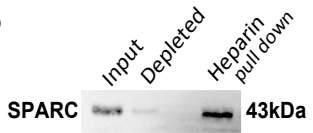

Figure 4 SPARC is PRESENT Within the ENDOTHELIAL GLyCOCALyX.

(A) SPARC showed positive staining in blood vessels coinciding with WGA (glycoproteins and proteoglycans stain), CD31 and VCAM-1 but not with CD45+ leukocytes during viral myocarditis. All images shown are representative, scale bar: $50 \mu \mathrm{m}$. (B)Electron microscopic imaging of cardiac capillaries and arterioles demonstrating compromised endothelial glycocalyx in heart sections of SPARC null mice (scale bar: 500nm). (lu: Lumen, gly: glycocalyx, ec: endothelial cell). (C) in vivo Glycocheck measurement in SPARC WT and null animals confirmed worse glycocalyx integrity in the absence of SPARC $\left({ }^{*} \mathrm{p}=0.04 ; \mathrm{n} \geq 8\right.$ per group). (D) Pull down of SPARC with protein A/G heparin coated sepharose beads in a cardiac endothelial cell lysate.

\section{SPARC and the Endothelial Glycocalyx are Essential for Maintaining Barrier Properties during Viral Myocarditis.}

Intra-vital microscopy of the cremaster microvessels allows for the study vascular permeability by quantifying the extravasation of fluorescently labeled Dextrans. Capillary leakiness due to TNFalpha was significantly higher in SPARC null as compared to WT mice ( $p>0.005$, Figure 5A-B). Interestingly, administration of recombinant SPARC significantly rescued the vascular leakiness observed in SPARC null animals (Figure 5A-B). To corroborate our finding in the cremaster to the microvasculature of other organs, two independent analyses of vascular permeability were performed. Evaluation of Evans blue uptake in various organs after systemic flushing showed that KO mice had higher amounts of Evans Blue in the heart, lung and liver as compared to WT mice but not in the spleen or skin (Figure 5C). Furthermore qualitative analysis of systemically injected microspheres shows higher amounts of beads in the cardiac environment of $\mathrm{KO}$ as compared to WT mice (Figure 5D). As a proof of concept, intra-vital microscopy was performed in WT mice where the glycocalyx was damaged ${ }^{13,25}$. 
A
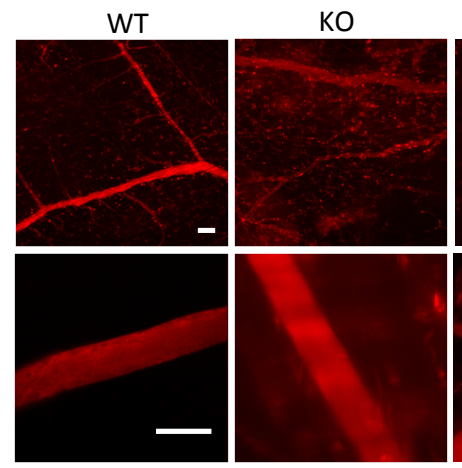

C

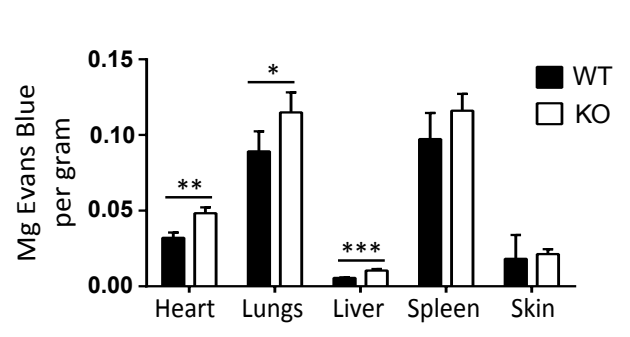

B

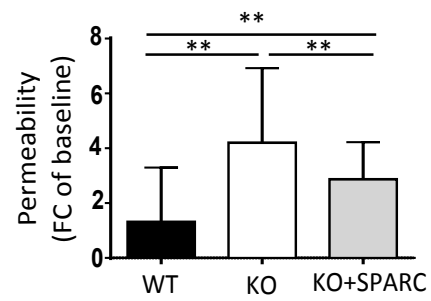

$\mathrm{D}$
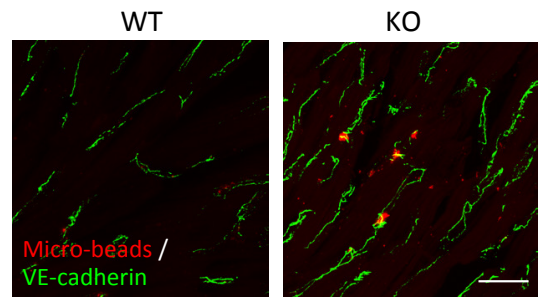

Figure 5 SPARC NeEded For PRESERVEd VASCular PERMeAbility.

(A) Images of the Texas Red labelled Dextran $40 \mathrm{kDa}$ in the vascular and its induced leakage by $\mathrm{TNF} \alpha$ in SPARC WT and null mice vessels. (I) The leakage in the SPARC null mice was higher than in WT mice, and could be reduced upon administration of SPARC $\left({ }^{* *} \mathrm{p} \leq 0.005\right)$. Scale bar: $50 \mu \mathrm{m}$. (B) Injection of Evans Blue in healthy SPARC WT and null animals resulted in significantly more leakiness of Evans Blue in KO cardiac, lung and liver as compared to WT $\left(\mathrm{n}=4,{ }^{*} \mathrm{p}=0.05,{ }^{* *} \mathrm{p}=0.005,{ }^{* * *} \mathrm{p}=0.0002\right)$ (D) Labelled micro-beads were injected and visualized after counterstaining with VE-cadherin revealed more extravasation in SPARC-null animals. (red: micro-beads, green: VE-cadherin, scale $=20 \mu \mathrm{m}$ )

Degradation of the glycocalyx by injection of hyaluronidase resulted in reduced leukocyte velocities $(p<0.001$, Figure 6A) and increased vascular leakiness ( $>0.0005$, Figure 6B-C). Again, increasing circulating levels of SPARC after enzymatic degradation of the endothelial surface layer restored leukocyte velocities and microvascular leakiness back to baseline values (Figure 6A-C). Finally, hyaluronidase-mediated degradation of the glycocalyx was performed in WT mice prior to CVB3 infection. Hyaluronidase treatment significantly increased the cardiac infiltration (Figure 6D) and CD 45+ content of the heart 7 days after viral infection $(4 \pm 1 \%$ in control vs. $9 \pm 2 \%$ in hyaluronidase treated; $\mathrm{p}<0.05$ ) (Figure $6 \mathrm{E}-\mathrm{F}$ ). Similarly to when SPARC is absent, hyaluronidase treatment did not affect the viral levels during the viremic phase (day 2, Figure 6G). Finally, to validate changes in endothelial glycocalyx during viral myocarditis levels of circulating hyaluronan were measured following CVB3 infection. Hyaluronan levels increased significantly 7 days after viral infection $(\mathrm{p}<0.05$, Figure $6 \mathrm{H})$. 


\section{DisCUSSION}

The present study demonstrates that the extracellular matrix protein SPARC is an essential regulator of microvascular barrier function via the endothelial glycocalyx, as leukocyte adhesion and vascular permeability increase when the endothelial barrier is compromised, either by lack of SPARC or by enzyme treatment of its major components (hyaluronans). Finally, these alterations in glycocalyx integrity result in increased cardiac inflammation and injury during viral myocarditis.

The composition of the glycocalyx is controlled by multiple factors and requires a timely balance between synthesis (sheer stress) and degradation (inflammation). Though little is known about the regulation of the glycocalyx, there is growing appreciation of its importance in organ homeostasis and disease. Numerous studies show that changes in shear stress, hypoxia, hyperglycemia, oxidized LDL or inflammation can induce glycocalyx perturbation and hence contribute to the vascular dysfunction observed in sepsis ${ }^{26}$, acute respiratory syndrome ${ }^{27}$, albuminuria ${ }^{28}$, atherosclerosis ${ }^{29}$, diabetes ${ }^{30}$ and obesity ${ }^{14}$.

A

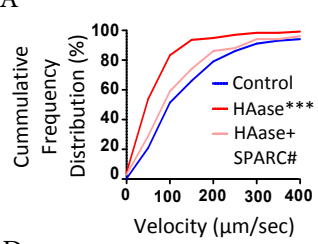

$\mathrm{D}$

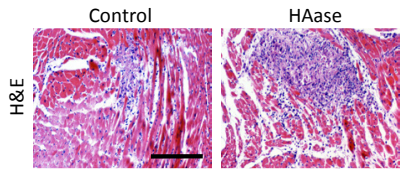

G

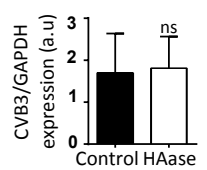

$\mathrm{H}$

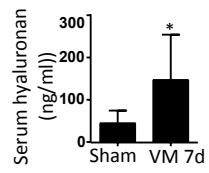

B

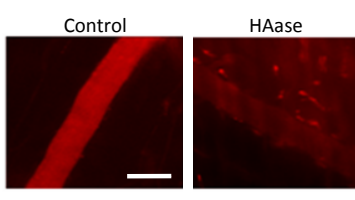

$\mathrm{E}$

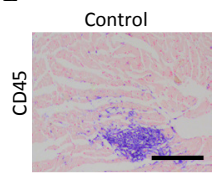

C

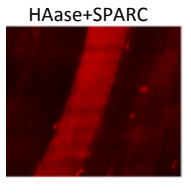

$\mathrm{F}$

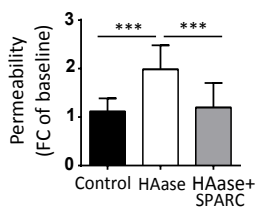

HAase

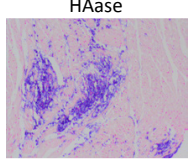

Figure 6 Glycocalyx integrity CRITICAL IN LIMITING ADVERSE inflammation.

(A) Significantly reduced leukocyte velocities were found in mice injected with hyaluronidase (HAase), which was reversible with SPARC protein administration (Control vs HAdase ${ }^{* * *} \mathrm{p}=0.0001$, HAase vs HAdase+SPARC $\# \mathrm{p} \leq 0.05$ ) (B) Vascular leakage induced by $\mathrm{TNF} \alpha$ of Texas Red labelled Dextran $40 \mathrm{kDa}$ after HAase treatement. (C) Significantly higher leakage in HAase mice as compared to the WT mice, which could be reversed using recombinant SPARC treatment $\left({ }^{* *} \mathrm{p}=0.005,{ }^{* * *} \mathrm{p}=0.0001\right.$; scale bar: $\left.50 \mu \mathrm{m}\right)$. (D) CD45+ staining of left ventricular sections from WT mice infected with CVB3 after receiving an intravenous hyaluronidase (HAdase) injection, day 7. (E) quantification of showing an increase in cellular infiltration in HAdase treated mice $\left({ }^{*} \mathrm{p} \leq 0.05, \mathrm{n} \geq 10\right.$ per group). (F) CVB3 cardiac expression was similar in both groups 2 days after -viral infection. (G) CVB3 infection induces a significantly increase in circulating hyaluronan levels after 7 days $\left({ }^{*} \mathrm{p} \leq 0.05 ; \mathrm{n} \geq 4\right.$ per group). 
This study is the first to implicate glycocalyx perturbations during viral myocarditis yet changes in myocardial glycocalyx have been observed in other cardiac pathologies such as ischemia-reperfusion injury ${ }^{31}$, excessive oedema ${ }^{32}$ and cardiogenic shock ${ }^{33}$. Furthermore a recent review about the cardiovascular manifestations of dengue fever, suggested that alterations in glycocalyx might contribute to the capillary leakiness observed during infection and contribute to the myocarditis observed ${ }^{34}$. The glycocalyx is a challenging entity to study due to its fragility and the difficulty in preserving its delicate structure. Using methodologies were the glycocalyx remains better intact we were able to observe that SPARC is needed for an intact glycocalyx. The need to have SPARC for proper endothelial glycocalyx composition has not been identified before, though in vitro studies have shown that SPARC can bind to albumin ${ }^{35}$, which itself can regulate glycocalyx integrity ${ }^{28}$. Glycoproteins have been suggested as important 'backbone' molecules for the glycocalyx structure ${ }^{36}$ and therefore it is possible that the limited glycocalyx in the SPARC null mice is due to a lack of glycocalyx anchoring rather than an impaired glycocalyx synthesis. Recent studies also show significant increases in plasma SPARC levels in patients with diabetes and coronary artery disease ${ }^{37,38}$ where increases of hyaluronan have also been described ${ }^{39,40}$.

Schmidt et al recently demonstrated the importance of the glycocalyx in affecting leukocyte adhesion as enzymatic treatment with heparanase compromised the glycocalyx and led to increased neutrophil adhesion ${ }^{41}$. Here we show that a disrupted glycocalyx either by the absence of SPARC or enzymatic treatment also results in higher capillary permeability and hence increased extravasation. In vitro experiments suggest that leukocyte-derived SPARC facilitate leukocyte transmigration across an endothelial monolayer ${ }^{42}$, and that applied SPARC induced changes in the endothelial cytoskeleton ${ }^{43}$. However, in vitro studies performed under static culture conditions, do not express a robust glycocalyx and hence cannot be used to assess the contribution of the glycocalyx to leukocyte-endothelial interactions. Our data are in line with previous in vivo studies where absence of SPARC resulted in increased inflammation and leukocyte recruitment during peritonitis ${ }^{44}$, bleomycin lung injury ${ }^{44,45}$ and hypersensitivity 46 , though no study up to now has explored the role of SPARC on vascular permeability in vivo. Interesting systemic administration of SPARC restored endothelial barrier properties, and reduced the adverse inflammation. During myocarditis systemic SPARC rescued KO mice survival though it did not affect the amount of myocyte cell injury as measured by troponin levels. These data suggest that infiltrating leukocytes brings on acute mortality during viral myocarditis, but that inflammatory dilated cardiomyopathy develops progressively. Similarly to the clinical scenario dilated cardiomyopathy was not present in all CVB3 infected mice at 9 weeks. However we did observe dilated cardiomyopathy in more KO mice than WT mice. Interestingly, $\mathrm{KO}$ mice that received SPARC during the first 5 weeks following viral infection had a trend to better cardiac function at 9 weeks as compared to $\mathrm{KO}$ mice that had not received SPARC at all $(29.7 \pm 7 \%$, vs $26.4 \pm 7 \%$ FS respectively, $\mathrm{p}=0.14)$. These data are in line with other studies showing that limiting the cardiac infiltration during the acute phase improves the long term function ${ }^{47}$.

Collectively, our data identify SPARC as crucial component of the endothelial barrier and thus prevents pathological cardiac inflammation. SPARC may therefore represent a novel therapeutic tool to repair or maintain endothelial barrier integrity, not only during viral myocarditis and but also in other diseases where the endothelial barrier is compromised such as septic shock, ischemia or diabetes. 


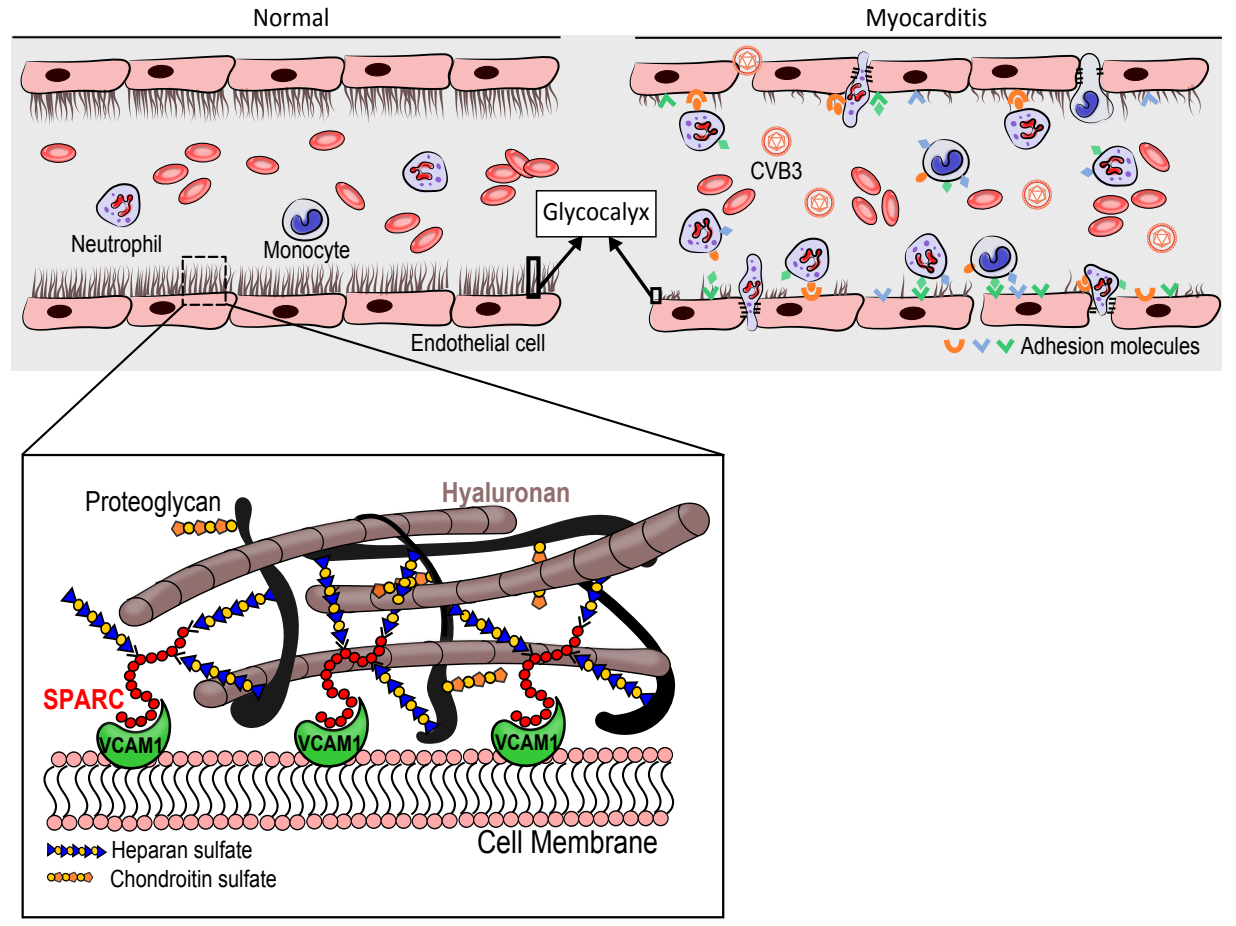

Figure 7 Scheme illustrating the proposed funCtion of SPARC MAINTAINing endothelial BarRier FUNCTION DURING VIRAL MYOCARDITIS. 


\section{REFERENCES}

$1 \quad$ Sagar S, Liu PP, Cooper LT, Jr. Myocarditis. Lancet 2012;379(9817):738-47.

2 Bornstein P, Sage EH. Matricellular proteins: extracellular modulators of cell function. Curr Opin Cell Biol 2002;14(5):608-16.

3 Schellings MW, Vanhoutte D, Swinnen M, Cleutjens JP, Debets J, van Leeuwen RE, d'Hooge J, Van de Werf F, Carmeliet P, Pinto YM, Sage EH, Heymans S. Absence of SPARC results in increased cardiac rupture and dysfunction after acute myocardial infarction. J Exp Med 2009;206(1):113-23.

4 Bradshaw AD, Baicu CF, Rentz TJ, Van Laer AO, Boggs J, Lacy JM, Zile MR. Pressure overload-induced alterations in fibrillar collagen content and myocardial diastolic function: role of secreted protein acidic and rich in cysteine (SPARC) in post-synthetic procollagen processing. Circulation 2009;119(2):269-80.

5 Bradshaw AD, Baicu CF, Rentz TJ, Van Laer AO, Bonnema DD, Zile MR. Age-dependent alterations in fibrillar collagen content and myocardial diastolic function: role of SPARC in post-synthetic procollagen processing. American journal of physiology Heart and circulatory physiology 2010;298(2):H614-22.

6 Francki A, Bradshaw AD, Bassuk JA, Howe CC, Couser WG, Sage EH. SPARC regulates the expression of collagen type I and transforming growth factor-beta1 in mesangial cells. The Journal of biological chemistry 1999;274(45):32145-52.

7 Said N, Frierson HF, Sanchez-Carbayo M, Brekken RA, Theodorescu D. Loss of SPARC in bladder cancer enhances carcinogenesis and progression. The Journal of clinical investigation 2013;123(2):751-66. Said N, Frierson HF, Jr., Chernauskas D, Conaway M, Motamed K, Theodorescu D. The role of SPARC in the TRAMP model of prostate carcinogenesis and progression. Oncogene 2009;28(39):3487-98.

9 Reed MJ, Bradshaw AD, Shaw M, Sadoun E, Han N, Ferara N, Funk S, Puolakkainen P, Sage EH. Enhanced angiogenesis characteristic of SPARC-null mice disappears with age. Journal of cellular physiology 2005;204(3):800-7.

10 Ley K, Laudanna C, Cybulsky MI, Nourshargh S. Getting to the site of inflammation: the leukocyte adhesion cascade updated. Nature reviews Immunology 2007;7(9):678-89.

11 Frangogiannis NG. Matricellular proteins in cardiac adaptation and disease. Physiol Rev 2012;92(2):635-88.

12 Schellings MW, Vanhoutte D, Swinnen M, Cleutjens JP, Debets J, van Leeuwen RE, d'Hooge J, Van de Werf F, Carmeliet P, Pinto YM, Sage EH, Heymans S. Absence of SPARC results in increased cardiac rupture and dysfunction after acute myocardial infarction. The Journal of experimental medicine 2009;206(1):113-23.

13 Potter DR, Jiang J, Damiano ER. The recovery time course of the endothelial cell glycocalyx in vivo and its implications in vitro. Circ Res 2009;104(11):1318-25.

14 Eskens BJ, Leurgans TM, Vink H, Vanteeffelen JW. Early impairment of skeletal muscle endothelial glycocalyx barrier properties in diet-induced obesity in mice. Physiological reports 2014;2(1):e00194.

15 Rouleau L, Copland IB, Tardif JC, Mongrain R, Leask RL. Neutrophil adhesion on endothelial cells in a novel asymmetric stenosis model: effect of wall shear stress gradients. Annals of biomedical engineering 2010;38(9):2791-804.

16 Radu M, Chernoff J. An in vivo assay to test blood vessel permeability. Journal of visualized experiments : JoVE 2013(73):e50062.

17 Perdiguero EG, Galaup A, Durand M, Teillon J, Philippe J, Valenzuela DM, Murphy AJ, Yancopoulos GD, Thurston G, Germain S. Alteration of developmental and pathological retinal angiogenesis in angpt|4deficient mice. The Journal of biological chemistry 2011;286(42):36841-51.

18 Bagher $P$, Segal SS. The mouse cremaster muscle preparation for intravital imaging of the microcirculation. J Vis Exp 2011(52).

19 Jakob SM, Pick R, Brechtefeld D, Nussbaum C, Kiefer F, Sperandio M, Walzog B. Hematopoietic progenitor kinase 1 (HPK1) is required for LFA-1-mediated neutrophil recruitment during the acute inflammatory response. Blood 2013;121(20):4184-94.

20 Weinbaum S, Tarbell JM, Damiano ER. The structure and function of the endothelial glycocalyx layer. Annu Rev Biomed Eng 2007;9:121-67.

21 Kolarova H, Ambruzova B, Svihalkova Sindlerova L, Klinke A, Kubala L. Modulation of endothelial glycocalyx structure under inflammatory conditions. Mediators of inflammation 2014;2014:694312.

22 Becker BF, Chappell D, Bruegger D, Annecke T, Jacob M. Therapeutic strategies targeting the endothelial glycocalyx: acute deficits, but great potential. Cardiovasc Res 2010;87(2):300-10.

23 Ihrcke NS, Wrenshall LE, Lindman BJ, Platt JL. Role of heparan sulfate in immune system-blood vessel 
interactions. Immunol Today 1993;14(10):500-5.

Pries AR, Secomb TW, Gaehtgens P. The endothelial surface layer. Pflugers Arch 2000;440(5):653-66. van den Berg BM, Vink H, Spaan JA. The endothelial glycocalyx protects against myocardial edema. Circ Res 2003;92(6):592-4.

Henrich M, Gruss M, Weigand MA. Sepsis-induced degradation of endothelial glycocalix. TheScientificWorldJournal 2010;10:917-23.

Mehta D, Ravindran K, Kuebler WM. Novel regulators of endothelial barrier function. American journal of physiology Lung cellular and molecular physiology 2014;307(12):L924-35.

Salmon AH, Ferguson JK, Burford JL, Gevorgyan H, Nakano D, Harper SJ, Bates DO, Peti-Peterdi J. Loss of the endothelial glycocalyx links albuminuria and vascular dysfunction. Journal of the American Society of Nephrology : JASN 2012;23(8):1339-50.

Koo A, Dewey CF, Jr., Garcia-Cardena G. Hemodynamic shear stress characteristic of atherosclerosisresistant regions promotes glycocalyx formation in cultured endothelial cells. American journal of physiology Cell physiology 2013;304(2):C137-46.

Perrin RM, Harper SJ, Bates DO. A role for the endothelial glycocalyx in regulating microvascular permeability in diabetes mellitus. Cell biochemistry and biophysics 2007;49(2):65-72.

Rubio-Gayosso I, Platts SH, Duling BR. Reactive oxygen species mediate modification of glycocalyx during ischemia-reperfusion injury. American journal of physiology Heart and circulatory physiology 2006;290(6):H2247-56.

van den Berg BM, Vink H, Spaan JA. The endothelial glycocalyx protects against myocardial edema. Circulation research 2003;92(6):592-4.

Jung C, Fuernau G, Muench P, Desch S, Eitel I, Schuler G, Adams V, Figulla HR, Thiele H. Impairment of the endothelial glycocalyx in cardiogenic shock and its prognostic relevance. Shock 2015;43(5):450-5. Yacoub S, Wertheim H, Simmons CP, Screaton G, Wills B. Cardiovascular manifestations of the emerging dengue pandemic. Nature reviews Cardiology 2014;11(6):335-45.

Schnitzer JE, Oh P. Antibodies to SPARC inhibit albumin binding to SPARC, gp60, and microvascular endothelium. The American journal of physiology 1992;263(6 Pt 2):H1872-9.

Reitsma S, Slaaf DW, Vink H, van Zandvoort MA, oude Egbrink MG. The endothelial glycocalyx: composition, functions, and visualization. Pflugers Arch 2007;454(3):345-59.

Takahashi M, Nagaretani H, Funahashi T, Nishizawa H, Maeda N, Kishida K, Kuriyama H, Shimomura I, Maeda K, Hotta K, Ouchi N, Kihara S, Nakamura T, Yamashita S, Matsuzawa Y. The expression of SPARC in adipose tissue and its increased plasma concentration in patients with coronary artery disease. Obesity research 2001;9(7):388-93.

Wu D, Li L, Yang M, Liu H, Yang G. Elevated plasma levels of SPARC in patients with newly diagnosed type 2 diabetes mellitus. Eur J Endocrinol 2011;165(4):597-601.

Morita M, Yano S, Ishibashi Y, Nakata N, Kurioka S, Sugimoto T. Close relationship between serum hyaluronan levels and vascular function in patients with type 2 diabetes. Biomarkers : biochemical indicators of exposure, response, and susceptibility to chemicals 2014;19(6):493-7.

Kucur M, Karadag B, Isman FK, Ataev Y, Duman D, Karadag N, Ongen Z, Vural VA. Plasma hyaluronidase activity as an indicator of atherosclerosis in patients with coronary artery disease. Bratislavske lekarske listy 2009;110(1):21-6.

Schmidt EP, Yang Y, Janssen WJ, Gandjeva A, Perez MJ, Barthel L, Zemans RL, Bowman JC, Koyanagi DE, Yunt ZX, Smith LP, Cheng SS, Overdier KH, Thompson KR, Geraci MW, Douglas IS, Pearse DB, Tuder RM. The pulmonary endothelial glycocalyx regulates neutrophil adhesion and lung injury during experimental sepsis. Nature medicine 2012;18(8):1217-23.

Kelly KA, Allport JR, Yu AM, Sinh S, Sage EH, Gerszten RE, Weissleder R. SPARC is a VCAM-1 counterligand that mediates leukocyte transmigration. J Leukoc Biol 2007;81(3):748-56.

Goldblum SE, Ding X, Funk SE, Sage EH. SPARC (secreted protein acidic and rich in cysteine) regulates endothelial cell shape and barrier function. Proceedings of the National Academy of Sciences of the United States of America 1994;91(8):3448-52.

Savani RC, Zhou Z, Arguiri E, Wang S, Vu D, Howe CC, DeLisser HM. Bleomycin-induced pulmonary injury in mice deficient in SPARC. American journal of physiology Lung cellular and molecular physiology 2000;279(4):L743-50.

Sangaletti S, Tripodo C, Cappetti B, Casalini P, Chiodoni C, Piconese S, Santangelo A, Parenza M, Arioli I, Miotti S, Colombo MP. SPARC oppositely regulates inflammation and fibrosis in bleomycininduced lung damage. The American journal of pathology 2011;179(6):3000-10.

Sangaletti S, Gioiosa L, Guiducci C, Rotta G, Rescigno M, Stoppacciaro A, Chiodoni C, Colombo MP. Accelerated dendritic-cell migration and T-cell priming in SPARC-deficient mice. Journal of cell science 2005;118(Pt 16):3685-94. 
47 Corsten MF, Papageorgiou A, Verhesen W, Carai P, Lindow M, Obad S, Summer G, Coort SL, Hazebroek $M$, van Leeuwen R, Gijbels MJ, Wijnands E, Biessen EA, De Winther MP, Stassen FR, Carmeliet $P$, Kauppinen S, Schroen B, Heymans S. MicroRNA Profiling Identifies MicroRNA-155 as an Adverse Mediator of Cardiac Injury and Dysfunction During Acute Viral Myocarditis. Circulation research 2012. 


\section{Supplementary Figures}

A

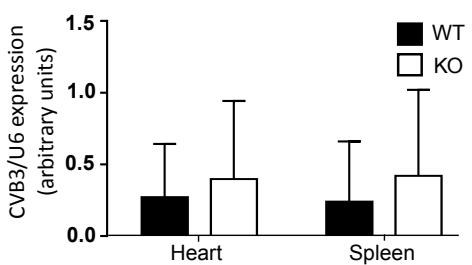

C

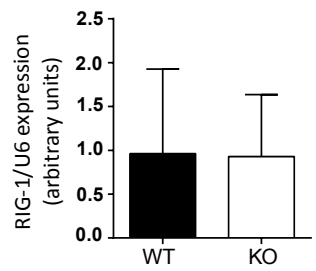

B

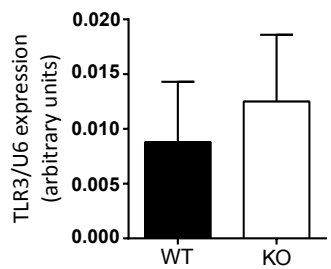

D

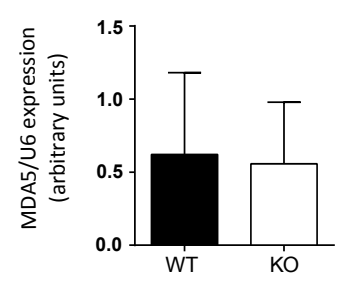

Supplementary Figure 1

(A)There were no differences in the transcript levels of CVB3 between SPARC WT and $\mathrm{KO}$ mice in the heart or the spleen 4 days after viral infection. (B-D) Also, no differences were found in the expression of virus recognition receptors TLR3, RIG-1 and MDA5 upon viral exposure $(n=5)$.
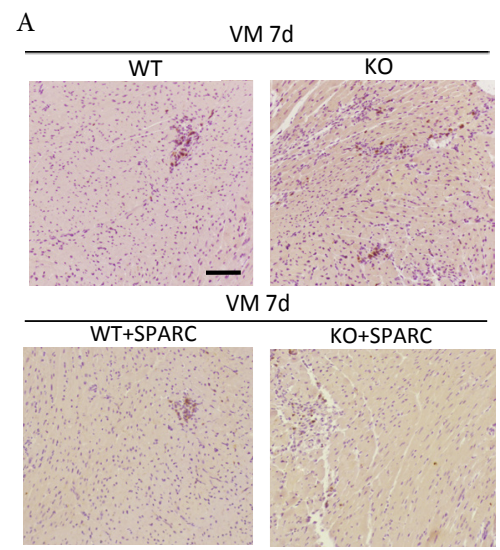

B

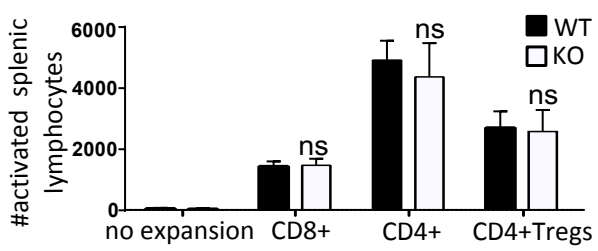

C

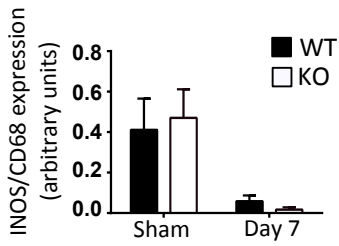

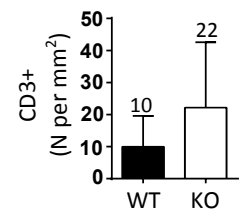

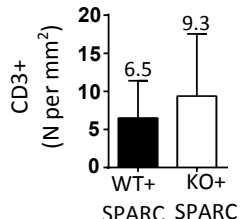

SPARC SPARC

\section{Supplementary Figure 2}

(A) CD3 staining and quantification showing an increase T-lymphocyte presence in SPARC KO hearts, $n \geq 10$ per group). Adenoviral overexpression of SPARC in null animals significantly reduced the amount of $\mathrm{CD} 3+$ infiltration in the heart $(n \geq 7$ per group). (B) Activation of CD4 (CD4+, CD25-) and CD8 T-lymphocytes with expander beads showed that absence of SPARC did not alter the proliferation of T-cells, nor the suppressive capacity of the regulatory T-cells $(n=3)$. (C-D) INOS and Arginase- 1 transcript levels did not differ between both genotypes $(n \geq 4)$. 
A Representative ECG of healthy mouse

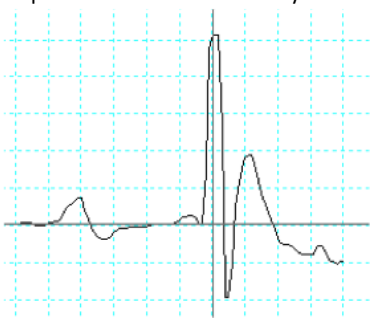

$\overline{\mathrm{B}}$

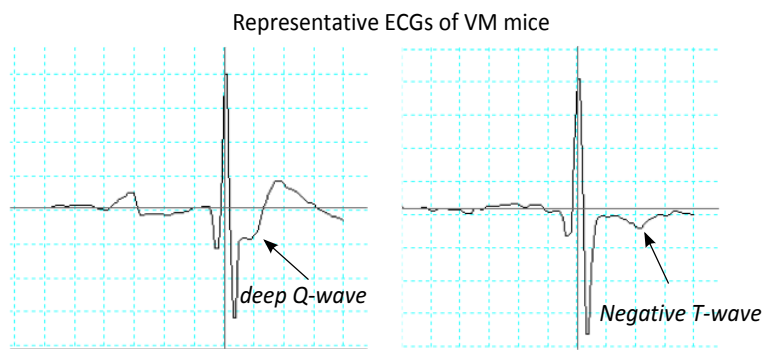

Supplementary Figure 3

(A)Representative ECG of a healthy mouse and examples of observed abnormalities, in WT mice such as (B) negative T-waves or deep Q-waves. 


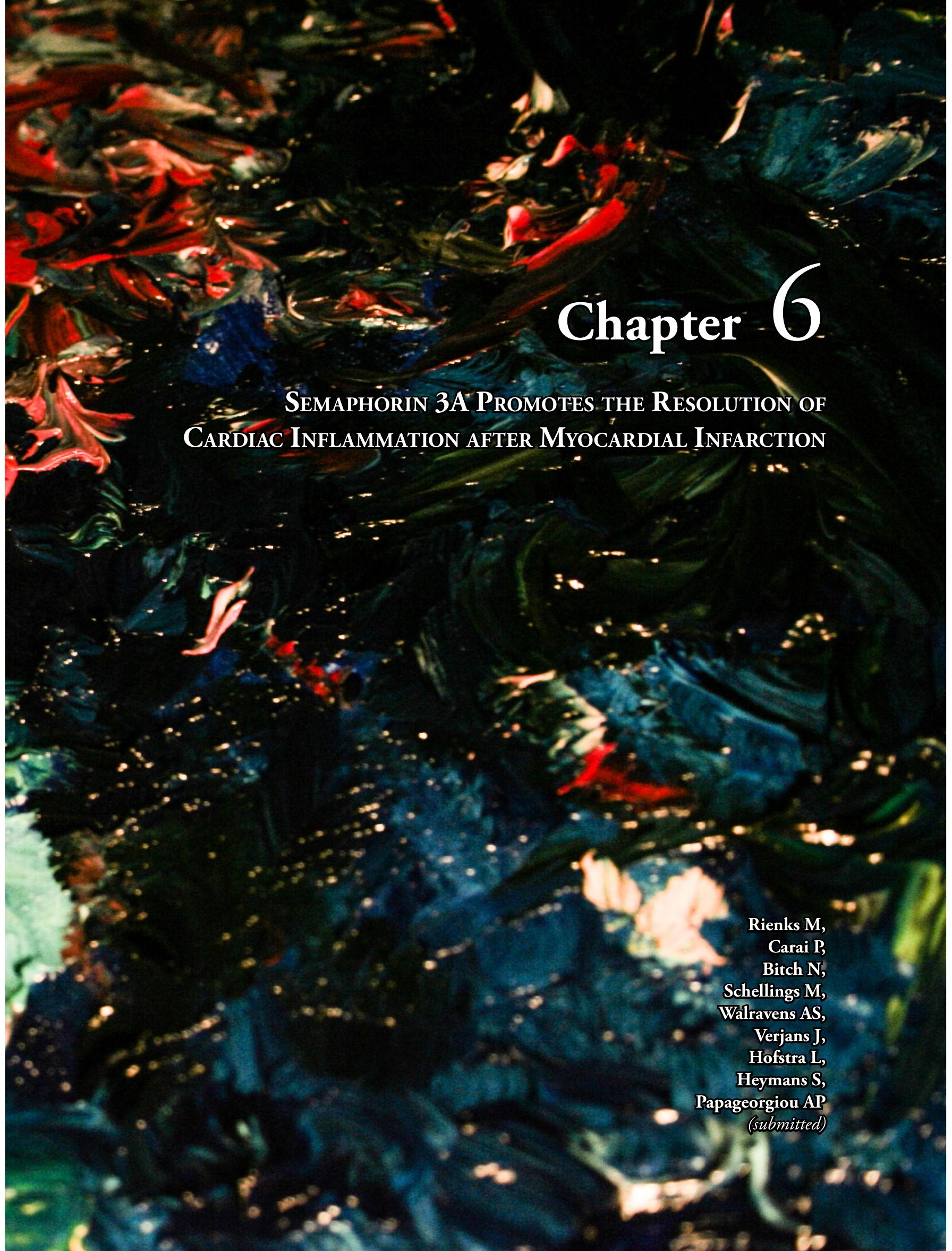




\section{Abstract}

Rationale and Objective: The involvement of cardiac inflammation in the development of heart failure has been recognized for some years now. Optimal healing after myocardial infarction requires not only its induction but also its timely resolution. Here we investigate whether Semaphorin3A regulates cardiac inflammation and hence represents a novel therapeutic target for ischemic heart disease.

Methods and Results: Expression of Sema3A increased in response to myocardial ischemia in mice from day 3-post myocardial infarction and was expressed predominantly by leukocytes. Subsequently, Semaphorin3A heterozygote and wild type mice were subjected to myocardial infarction. Whilst infarct sizes were similar 14 days after infarction, infarct thickness and fractional shortening were significantly reduced in Semaphorin3A heterozygous mice as compared to their wild type littermates $(11 \pm 2 \%$ vs $17 \pm 2 \%$ respectively, $\mathrm{p}<0.05)$. Furthermore, significantly more CD 45 positive cells were present in the infarcted area in the heterozygotes as compared to wild type hearts, with no differences in cardiac blood vessel density, fibrosis or cardiomyocyte cross sectional area. Reduced Semaphorin3A also resulted in increased cardiac inflammation in the coxackie-B3 myocarditis model. In vitro experiments showed that stimulation with recombinant protein Semaphorin3A retards the migration of monocytes, induces the apoptosis of classical macrophages, promotes their polarization to resolution-phase macrophages and enhances their efferoctytic ability. Finally, in cardiac tissue from the mouse model of myocardial infarction Semaphorin3A heterozygous mice had lower expression of apoptotic markers as well as markers for resolution-phase macrophages.

Conclusion: Collectively our data demonstrates that Semaphorin3A reduces cardiac inflammation and improves cardiac function after myocardial infarction by promoting the resolution of inflammation. 


\title{
INTRODUCTION
}

The improved clinical management of acute myocardial infarction (AMI) has resulted in a substantial reduction in mortality, yet this has led to the increased prevalence of heart failure and represents a huge socio-economic burden ${ }^{1}$. Cardiac inflammation in response to ischemia is key for repairing the damaged myocardium yet sustained inflammation results in adverse remodeling and consequently poor cardiac function and prognosis ${ }^{2}$. Thus post-infarct inflammation is a double edge sword needing containment via the timely clearance of recruited pro-inflammatory leukocytes ${ }^{3}$. The recruitment of pro-inflammatory monocytes (LyChi) has been well characterized ${ }^{4}$ but little is known about factors that switch off inflammation. Recent studies have introduced the possibility that the transition to repair is not solely driven by the recruitment of reparative monocytes (LyClow) from the circulation but suggest that local factors may be key in promoting resolution from within the heart ${ }^{5}$. Understanding the molecular mechanisms that underline the transition to repair is important in designing new effective therapeutic strategies.

Semaphorin 3A (Sema3A) is a secreted glycoprotein first identified as a chemo-repellent during axonal guidance, 6 and crucial for embryonic development ${ }^{7,8}$. In addition to its involvement in cell motility9 and neuronal-vascular growth ${ }^{10,11}$, Sema3A has also been ascribed tumor-reducing capacities ${ }^{12}$ and anti-inflammatory properties during dermatitis ${ }^{13}$, autoimmune arthritis ${ }^{14}$ and kidney injury ${ }^{15}$. Sema3A is also a potent suppressor of T-lymphocyte activity ${ }^{16-19}$. In the failing heart, Sema3A is expressed by cardiomyocytes and is thought to contribute to the sympathetic denervation in chronic heart failure ${ }^{20}$, yet its function during cardiac inflammation is unknown. In this study, we identify Sema3A as a key factor in promoting the resolution of inflammation thereby facilitating cardiac wound healing and improving cardiac function.

\section{Material ANd Methods}

\begin{abstract}
Animals
For this study sema3A heterozygote knock out (HZ) mice and Wild type (WT) mice were used, and were a gift from dr. J. Verhaagen, Netherlands Institute for Neuroscience, Amsterdam. All animal experiments were approved by the Animal Care Committees of Maastricht University (DEC 2007-051/2013-055) and Leuven University (ECD 232/2013). Mice were age-matched at the start of the experimental protocol and experiments were performed using both male and female mice at random.

Myocardial Infarction Model

Myocardial infarction was induced by ligation of the left anterior descending artery after subcutaneously anaesthetizing the animals with a mix of ketamine xylazine, respectively 100 $\mathrm{mg} / \mathrm{kg}$ and $5 \mathrm{mg} / \mathrm{kg}$ subcutaneously in a volume of $0,1 \mathrm{ml} 0,9 \% \mathrm{NaCl} / 10$ gram bodyweight. After anesthetizing, the animals were intubated with a 20-gauge intra-tracheal cannula. Rectal temperature was constantly measured during the procedures. After shaving the animals, an incision was made microscopically. As a clear view of the left coronary artery is reached, the left anterior descending artery was ligated. After successful ligation of the left anterior descending artery, the wound was closed with soluble stitches. Sham operations included all procedures except ligation of the left anterior descending artery. Echocardiography was performed prior to sacrifice at 2 weeks post myocardial infarction. Heart, lung, kidney and liver weights were
\end{abstract}


measured. The left ventricle was separated from the heart and divided for histological and molecular analyses. Heart tissue for molecular analyses was immediately placed in liquid nitrogen, and stored at $-80^{\circ} \mathrm{C}$.

\section{ECHOCARDIOGRAPHY}

To gain echocardiographic images, the animals were anesthetized by ventilation with isoflurane $3-4 \%$. The anesthesia was maintained by artificially ventilating with a mixture of $\mathrm{O} 2$ and $\mathrm{N} 2 \mathrm{O}[1: 2(\mathrm{vol} / \mathrm{vol})]$ to which isoflurane $1.5-2.5 \%$ was added. Standard views were obtained in 2-D as well as M-mode by transthoracic echocardiography using a $12 \mathrm{MHz}$ probe (Hewlett Packard, Amsterdam, the Netherlands) on a Visual Sonics echocardiograph.

\section{Viral Myocarditis Model}

Eight to 12-week old Sema3A HZ and WT mice were inoculated intra-peritoneal (i.p.) with $1 \times 107$ cell culture 50\% infective dose (CCID50) of CVB3 (Nancy Strain) diluted in $0.2 \mathrm{~mL}$ of saline on day 0 . All animals were anaesthetized with an i.p. injection of Xylazine $(10 \mathrm{mg} / \mathrm{kg})$ and Ketamine $(100 \mathrm{mg} / \mathrm{kg})$ and sacrificed by cervical dislocation 4 or 7 days after CVB3 infection. Organs were excised for further molecular and histological analysis.

\section{STAINING AND IMMUNOHISTOCHEMISTRY}

Hearts were perfused from the apex with phosphate buffered saline (PBS), fixed overnight and processed the following day, before being embedded in paraffin. The embedded left ventricle was cut longitudinally in $4 \mu \mathrm{m}$ sections to optimally demonstrate the infract area. Sections were stained with hematoxylin/eosin for detection of infarct size and thickness. Collagen was stained on cardiac sections using Sirius Red, and the amount of collagen was quantified. Immunohistochemistry on paraffin sections was performed according to protocol using antibodies against CD45 (leukocytes), CD68 or Mac-3 (macrophages) CD31 (endothelial cells) and sema3A and quantified in the infarct area. Images were acquired using Leica Qwin image processing software (Leica, Germany).

\section{WESTERN BLOT}

Tissues were lysed in RIPA SDS (50mM TrisHCl, $150 \mathrm{mM} \mathrm{NaCl,} \mathrm{0.1 \%} \mathrm{SDS,} \mathrm{0.5 \%}$ sodium deoxycholate, 1\% NP40, Proteinase Inhibitor Cocktail, Roche, 11697498001 and $0.5 \mathrm{mM}$ Orthovandedate) after which the protein concentration was determined using a Micro BCA Protein assay kit (Thermo Scientific, lot\# MJ162220). Samples were diluted to a final concentration of $2 \mathrm{ug} / \mathrm{ul}$ after which two times sample buffer $(25 \mathrm{ml} 0.5 \mathrm{M}$ Tris HCl, $20 \mathrm{ml}$ $100 \%$ glycerol, 20ml, 20\% SDS, $35 \mathrm{ml}$ Aqua Dest with 1:10 $\beta$-Mecarptoethanol) was added to protein samples $1: 1$. Cells were directly lysed in sample buffer. For western blot analyses $20 \mathrm{ug}$ protein was loaded on a $10 \%$ gel $(4 \mathrm{ml}$ Aqua Dest, $3.3 \mathrm{ml} 30 \%$ AcrylBisAmide, $2.5 \mathrm{ml}$ $1.5 \mathrm{M}$ TrisHcl pH8.8, $0.1 \mathrm{ml} 10 \%$ SDS, $0.004 \mathrm{ml}$ TEMED). SDS PAGE was performed at $150 \mathrm{~V}$ for approximately 90 minutes after which the gel was transferred to a PVDF membrane by blotting at $200 \mathrm{~mA}$ for 2 hours. Membranes were blocked with 3.5\% protifar for 1 hour. Overnight primary antibody incubation was performed in 5\% BSA with antibodies against Semaphorin 3A (Abcam, ab23393), Cleaved Caspase 3 (Cell Signaling Technology (CST) \#9664S), BCL2 (Cell Signaling Technology (CST) \#2870S), GAPDH (Milipore, MAB374). 


\section{RTPCR}

Real-time reverse transcriptase-polymerase chain reaction (RT-PCR or QPCR) analysis was performed (Bio-Rad, Maastricht, Netherlands) to describe transcript levels of sema3A (forward primer CGGTGGCTCAATGATCCTAGA, reverse primer TTTGTCATCTTCAGGGTTGTCACT at $63.9^{\circ} \mathrm{C}$ ), CVB3 (forward primer ACGAATCCCAGTGTGTTTTGG, reverse primer TGCTCAAAAACGGTATGGACAT at $63.9^{\circ} \mathrm{C}$ ), GAPDH (forward primer GGTGGACCTCATGGCCTACA, reverse primer CTCTCTTGCTCAGTGTCCTTGCT at $63.9^{\circ} \mathrm{C}$ ). The primers sequences of these genes were determined by NCBI software analysis of Primer BLAST. Details of sequences and thermal cycle conditions are according to protocol. Data were acquired and analyzed IQ5 software (Bio-Rad, Maastricht, Netherlands).

\section{MONOCYTE ISOLATION FORM MURINE SPLEENS}

Spleens were collected from sema3A WT and HZ mice and cut into small pieces. With the back of a syringe the spleen was pushed through a $70 \mu \mathrm{m}$ Cell Strainer (BD Falcon) while rinsing with ice cold PBS. After collection the cells in a $50 \mathrm{ml}$ tube they were spun down. A single cell suspension was obtained by dissolving the cells in $1 \mathrm{ml}$ ice cold PBS which and followed by manual counting of cell with the use of a Burker Turk Counting chamber. Cells were spun down again and dissolved in the appropriate volume of PBS for MACS miltenyi monocyte isolation. Monocytes were isolated using mouse CD11b Microbeads (Miltenyi) and MACS LS separation columns (Miltenyi) according to manufacturer's protocol. After isolation, monocytes were labeled using CFSE (CellTrace ${ }^{\mathrm{TM}}$ CFSE Cell Proliferation Kit) according to manufacturer's protocol.

\section{Chemotaxis Assay or Boyden Chamber Assay}

250.000 monocytes were seeded onto the upper chamber fluoroblok inserts (Falcon, Fluorescence Blocking PET track-etched membrane 24-well format) in $200 \mu \mathrm{l}$, while $700 \mu \mathrm{l}$ of phenol free RPMI containing either sema3A or fMLP was filled into the lower one. Monocyte migration was monitored by acquiring six microscopic images per well, avoiding the center and edges of the well. These images were taken at 1,2 and 4 hours for spontaneous migration, and 4 hours for comparing WT and HZ monocyte chemotaxis. Images were analyzed using ImageJ software.

\section{Bone Marrow Derived Macrophages Isolation}

Both tibia and femurs were collected form Sema3A WT mice in ice cold PBS and stripped from muscles. After placing the stripped bones in 70\% Ethanol for approximately 45 seconds they washed again with PBS after which the ends were cut off and the inner bone marrow was flushed out with a 25G syringe filled with cold PBS. After flushing all the bones a single cell suspension was obtained by pushing the suspension through a $100 \mu \mathrm{m}$ Nylon cell strainer. Cells were spun down at $1200 \mathrm{rpm}$ and placed in bacterial plates in RPMI 1640 with 15\% LCM for culture and differentiation for approximately 8 to 10 days, adding or replacing medium every 2-3 days. Experiments were performed after differentiation of 8-10 days. Cells were counted using a Burker Turk cell counting chamber and 400.000 cells seeded in 12 -wells plates. The cells were stimulated the next day after the cells had adhered to the plastic. At the end of the experiments the cells were directly harvested in RLT buffer for RNA isolation, and sample buffer for immunoblotting. 


\section{EFFEROCYTOSIS Assay}

Macrophages (200.000) were seeded in 24-well tissue culture plate and polarized with either $10 \mathrm{ng} / \mathrm{ml} \mathrm{LPS}$ and $10 \mathrm{ng} / \mathrm{ml} \mathrm{INF}-\gamma$ or $10 \mathrm{ng} / \mathrm{ml} \mathrm{IL-10} \mathrm{with} \mathrm{and} \mathrm{without} \mathrm{presence} \mathrm{of}$ $150 \mathrm{ng} / \mathrm{ml}$ recombinant sema3A. Jurkat-cells were cultured in $10 \mathrm{~mm}$ dishes in RPMI 1640 with 10\%FBS. Jurkat-cells were stained with CFSE (CellTrace ${ }^{\mathrm{Tm}}$ CSFE (Cat. no. C34554), Life Technologies), according to the protocol supplied by the manufacturer. Briefly, cells were spun down and incubated with CFSE labeling solution (1:1000 in warm PBS) for approximately 15 minutes at 37 degrees $C^{\circ}$. Subsequently, they were re-pelleted and incubated in fresh prewarmed medium for another 30 minutes. After washing the cells with PBS they were counted and re-suspended in $10 \mathrm{ml}$ medium in a $10 \mathrm{~mm}$ dish. Irradiating the cells for $5 \mathrm{~min}$ with $1200 \times 100 \mu$ Joule/cm 2 induced apoptosis in the Jurkat cells. To ensure homogenous exposure the plate was swirled every 60 seconds. The irradiated cells were incubated for another 2 hours after which they were seeded in a 1:1 ratio on top of the seeded macrophages and incubated with the polarized macrophages for approximately 45 minutes. Afterwards they were removed and the macrophages washed twice with ice cold PBS and fixed with 1\% Paraformaldehyde for 10 minutes. Cells were then washed again with PBS after which images were taken immediately.

\section{Statistical Analysis}

Data were expressed as mean \pm SEM. No repeated measurements were performed. Echocardiograph measurements and histological and molecular analysis in sham operated and infarct groups were performed in independent groups. Normal distribution of all continuous variables was tested using the method Kolmogorov and Smirnov. An unpaired T-test was used in most of the comparisons when groups passed the normality test. However, a Mann-Whitney test was used when the standard deviations of two groups were significantly different. A two sided $\mathrm{P}$ value $<0.05$ was considered statistically significant.

\section{RESULTS}

Sema3A Expression InCreases during Myocardial Infarct Healing

Three days after myocardial infarction Sema3A gene expression increased significant in the areas bordering the infarcted tissue $(\mathrm{p}<0.05)$, returning back to baseline levels after 14 days (Fig. 1A, $\mathrm{p}<0.005)$. In the infarcted area expression of Sema3A transcripts increased significantly only at 14 days after infarction (Fig.1B, p<0.001). Concomitantly, Sema3A expression was observed predominantly in the border zone and not in the infarcted area at 3 days (Fig. 1C), whilst at 14 days Sema3A expression was concentrated within the infarct (Fig. 1D). While sema3A co-localized with some CD31 positive capillaries (Fig. 1E) at 14 days, sema3A was detected on infiltrated leukocytes and specifically on the resident macrophage population. 
Table 1 Echocardiography at baseline and i4 Days post-Mi.

\begin{tabular}{lcccc}
\hline & \multicolumn{2}{c}{ Sham } & \multicolumn{2}{c}{ 14 days post-MI } \\
\hline \hline & $\begin{array}{c}\text { WT } \\
\mathbf{n}=\mathbf{8}\end{array}$ & $\begin{array}{c}\text { HZ } \\
\mathbf{n = 1 0}\end{array}$ & $\begin{array}{c}\text { WT } \\
\mathbf{n = 1 3}\end{array}$ & $\begin{array}{c}\text { HZ } \\
\mathbf{n}=\mathbf{1 4}\end{array}$ \\
\hline \hline IVSd (mm) & $0.8 \pm 0.02$ & $0.8 \pm 0.04$ & $0.6 \pm 0.06$ & $0.5 \pm 0.05 £$ \\
\hline LVPWd (mm) & $0.8 \pm 0.02$ & $0.8 \pm 0.02$ & $0.8 \pm 0.04$ & $0.7 \pm 0.04$ \\
\hline LVIDd (mm) & $3.9 \pm 0.07$ & $3.9 \pm 0.07$ & $4.9 \pm 0.2 £$ & $4.6 \pm 0.1 £$ \\
\hline LVIDs (mm) & $2.7 \pm 0.05$ & $2.8 \pm 0.07$ & $4.1 \pm 0.2 £$ & $4.0 \pm 0.1 £$ \\
\hline FS (\%) & $30 \pm 0.5$ & $30 \pm 0.8$ & $17 \pm 1.9 £$ & $11 \pm 1.6^{*} £$ \\
\hline Heart rate (bpm) & $543 \pm 55$ & $576 \pm 27$ & $580 \pm 22$ & $597 \pm 15$ \\
\hline
\end{tabular}

IVSd, interventricular septum diastole; LVPWd, left ventricular posterior wall diastole; LVIDd, left ventricular internal diameter diastole; LVIDs, left ventricular internal diameter systole; FS, fractional shortening; $M I$, myocardial infarction

$£ p<0.05$ sham versus $M I$

${ }^{*} p<0.05$ Sema3A WT vs HZ post-MI

A

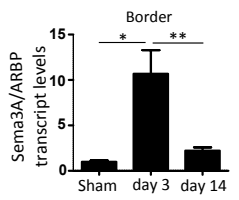

C

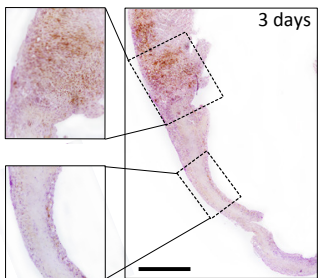

$\mathrm{D}$
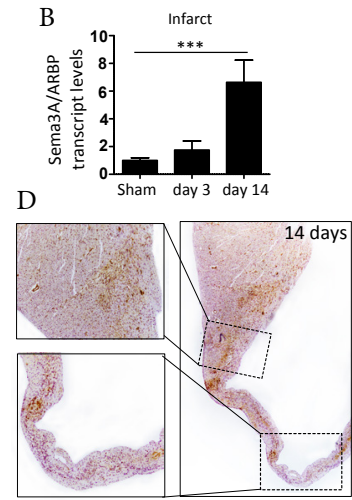

E

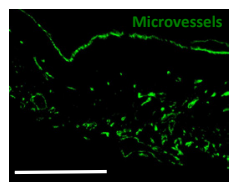

Myocardial Infarction 14 days
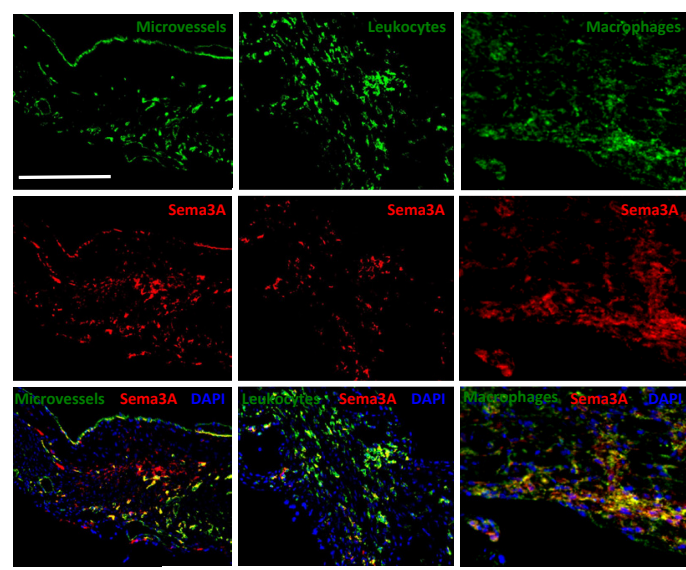

Figure 1 SemazA expression INCREASES DURING INFARCT HEALING

AND IS PRESENT ON MACROPHAGES. (A) RNA Sema3A expression increased significantly in the border zone three days after myocardial infarction $\left({ }^{*} \mathrm{p}<\right.$ $0.05,{ }^{* *} \mathrm{p}<0.01, \mathrm{n} \geq 4$ ). (B) Fourteen days after ischemic injury, the expression also increased in the infarcted area $\left(^{* * *} \mathrm{p}\right.$ $<0,001, \mathrm{n} \geq 4$ ). (C-D) The expression of sema3 $\mathrm{A}$ in both the infarct and border zone was confirmed by immunohistochemistry. Where sema3A expression predominated in the border zone 3 days after MI, fourteen days after MI the increased expression in the infarct became more apparent. Immunofluorescence further revealed sema3A location on microvessels but most importantly on leukocytes and macrophages (E). All experiments were repeated at least twice. Scale bar: $50 \mu \mathrm{m}$. 


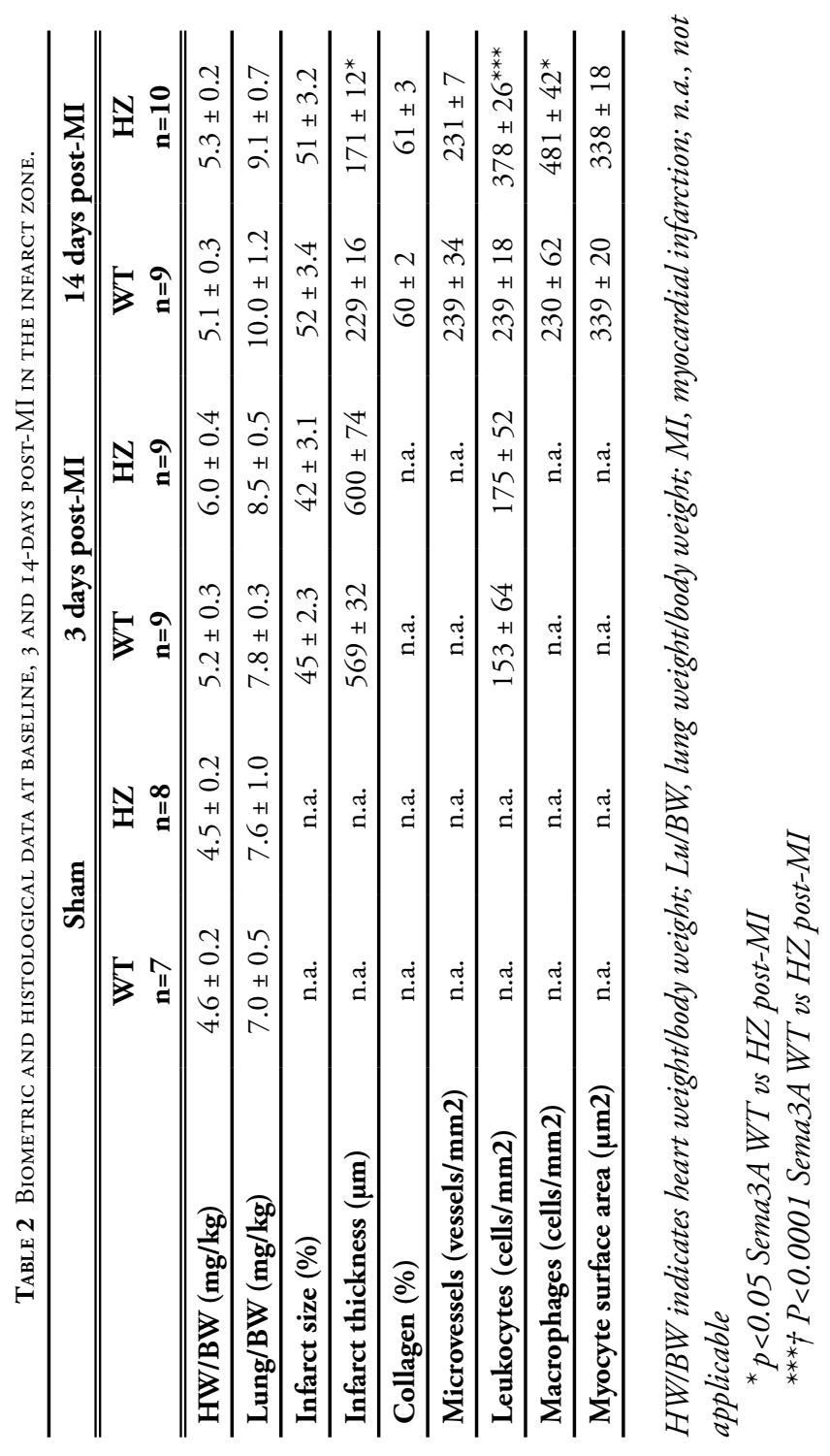




\section{Sema3A Reduces Cardiac Inflammation after Myocardial Injury}

Sema3A Knockout mice are embryonically lethal ${ }^{7}$. Therefore, Sema3A WT and HZ mice were subjected to the mouse model of myocardial infarction (Fig. 2A). Though mortality and infarct size between both genotypes were similar (Fig. 2A-C), fractional shortening was significantly reduced in Sema3A HZ as compared to WT mice $(\mathrm{p}<0.05$, Fig. 2D, table 1$)$. Furthermore no significant differences in collagen content, cardiomyocyte hypertrophy or capillary density were seen within the infarcted area between genotypes (Table 2). However, the amount of CD45-positive leukocytes was significantly greater in Sema3A HZ than in WT mice in the border zone at 3 days, but did not differ in the infarct zone ( $\mathrm{p}<0.005$, Fig. 2E-F).

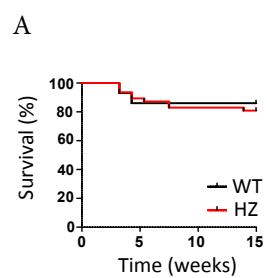

$\mathrm{E}$

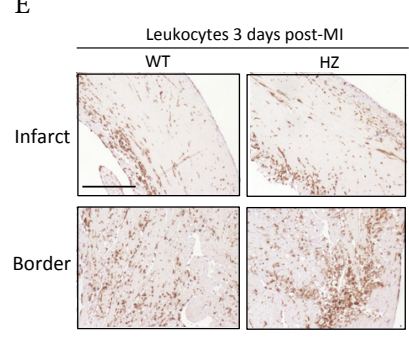

$\mathrm{B}$

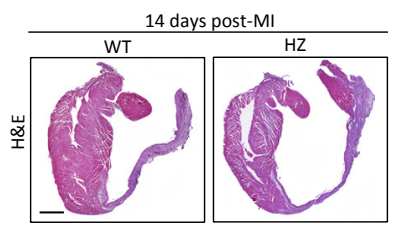

C

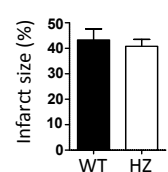

G
F

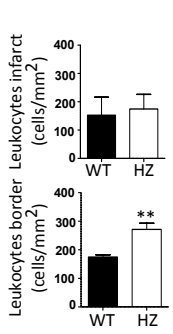

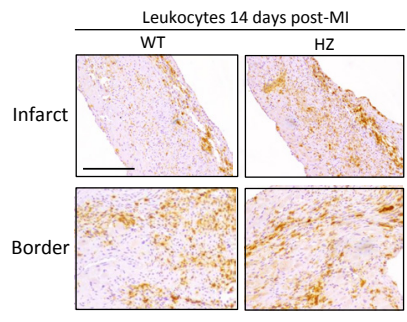

$\mathrm{D}$

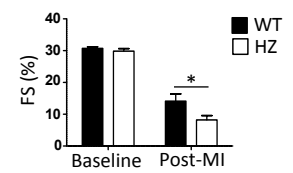

$\mathrm{H}$

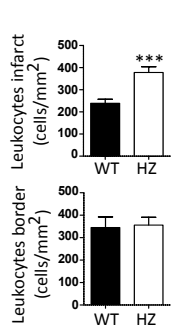

Figure 2 Sema3A regulates inflammation during infarct healing.

(A) Coronary artery occlusion in sema3A WT and HZ mice did not result in a difference in mortality. (B-C) Despite comparable infarct sizes between both groups, sema3A HZ mice showed worse cardiac function with decreased fractional shortening $\left(\mathrm{D},{ }^{*} \mathrm{p}<0.05, \mathrm{n} \geq 13\right)$. The number of recruited immune cells was determined by immunohistochemical staining for both the infarct and the border zone, three and fourteen days after MI. (E) Sema3A $\mathrm{HZ}$ had more leukocytes in the border zone three days after ischemic injury as compared to WT (** $\mathrm{p}<0.01, \mathrm{n} \geq 4$. (F) Fourteen days after infarction the increased presence of leukocytes in sema3A HZ mice was also apparent in the infarct area. $\left.{ }^{* * *} \mathrm{p}<0.001, \mathrm{n} \geq 9\right)$ All experiments were repeated at least twice.

Inversely, at 14 days post MI a significant greater number of CD45-positive leukocytes was observed in the infarct zone of sema3A HZ mice as compared to WT mice but not in the border ( $\mathrm{p}<0.001$, Fig. 2G-H). Finally, more macrophages were present in the infarcted area of the sema3A HZ mice as compared to WT mice at 14 days ( $<<0.005$, Table 2$)$.

Sema3A expression was observed on the cardiac leukocytes and macrophages in a second model of cardiac injury (the murine model of viral myocarditis, Fig. 3A). In addition, Sema $\mathrm{HZ}$ mice had a greater degree of cellular infiltration after 7 days $(\mathrm{p}<0.05$, Fig. $3 \mathrm{~B})$, though viral gene expression in the heart was similar during the viremic phase of disease (data not shown). Finally, Sema3A HZ mice had increased cardiac leukocytes and macrophages as compared to WT mice ( $\mathrm{p}<0.05$,Fig. 3C-D). 
A
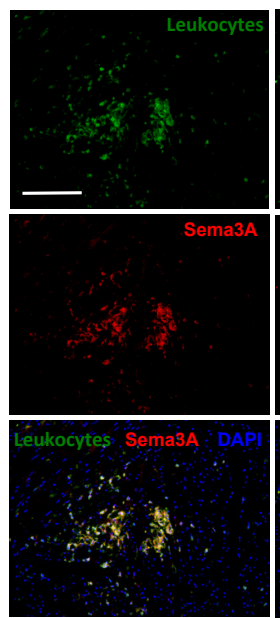

Viral Myocarditis day 7
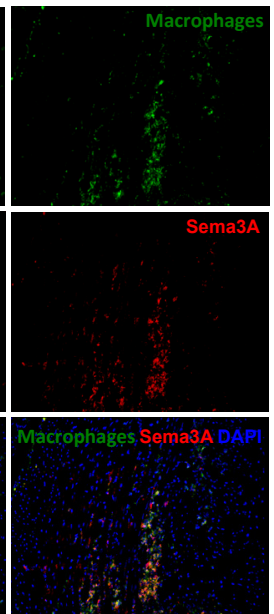

$\overline{\mathrm{B}}$

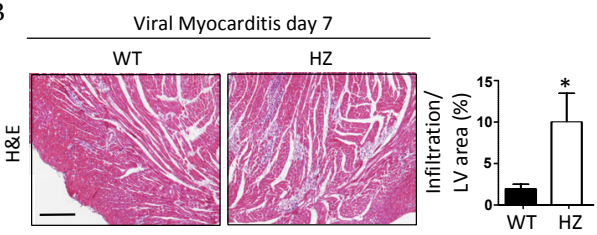

C

Viral myocarditis day 7

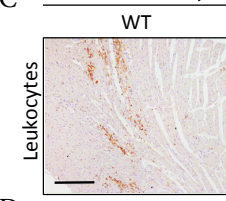

$\mathrm{D}$
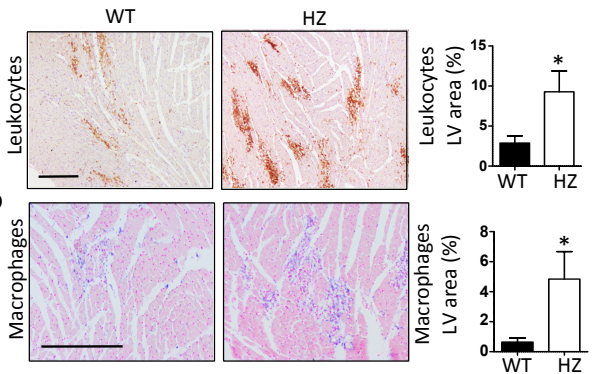

Figure 3 Sema3A regulates inflammation during Viral myocarditis.

(A) Immunofluorescence in human CVB3-induced viral myocarditis revealed the presence of sema3A on leukocytes and macrophages. (B) Analysis of H\&E staining in Sema3A HZ mice demonstrated significantly increased cellular infiltration relative to WT mice seven days after viral exposure and the quantification of staining ( $\left.{ }^{* *} \mathrm{p}<0.01, \mathrm{n} \geq 11\right)$. (C) Increased immune infiltration in Sema3A HZ mice was confirmed by the greater presence of CD45 positive leukocytes and (D) and macrophages $\left({ }^{*} \mathrm{p}<0.05, \mathrm{n} \geq 11\right)$. Scale: $50 \mu \mathrm{m}$

A

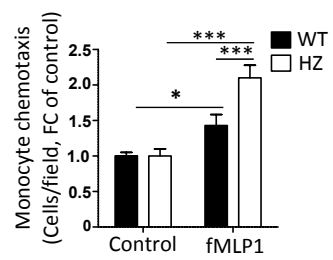

C

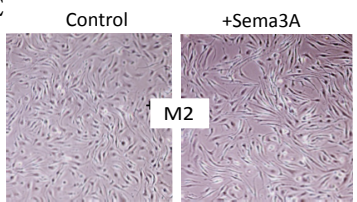

$\mathrm{D}$

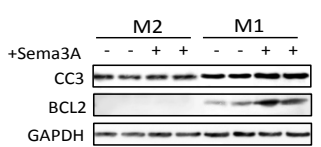

G

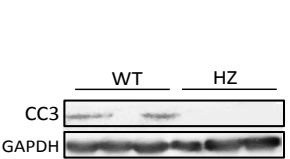

$\mathrm{E}$

$\mathrm{B}$

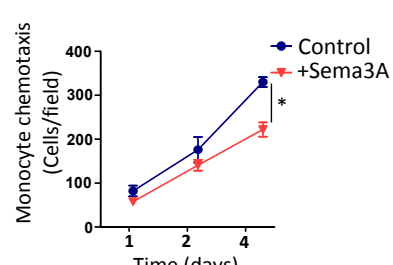

Control

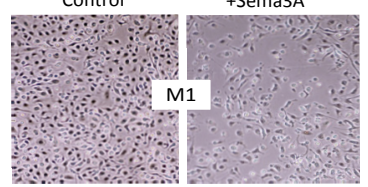

$\mathrm{F}$
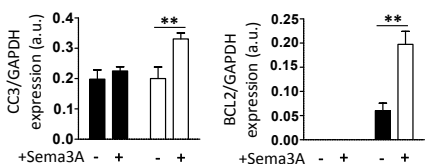

Figure 4 Sema3A inhibits chemotaxis AND PROMOTES PRO-INFLAMMATORY MACROPHAGES CLEARANCE BY INDUCING APOPTOSIS.

The migratory capacity of isolated splenic monocytes was assessed using a Boyden Chamber Assay for chemotaxis. (A) The migratory capacity of sema3A WT and HZ monocytes towards the chemoattractant fMLP1 revealed the decreased migratory capacity in sema3A WT monocytes as compared to $\mathrm{HZ}\left({ }^{*} \mathrm{p}<0.05,{ }^{* * *} \mathrm{p}<0.001\right.$, $\mathrm{n}=4$ ). (B) Sole presence of sema3A in the lower chamber significantly confirmed decreased migration by inhibiting spontaneous migration of monocytes ( ${ }^{*} \mathrm{p}$ $<0.05, \mathrm{n}=4$ ). (C) Bone Marrow Derived Macrophages were isolated and polarized for 24 hours in the presence of either IL-10 or LPS in combination with INF $\gamma$ towards M2 and M1 respectively. Stimulation of M1 with sema3A resulted in a decreased cell density as compared to M2 cells. Western blot analyses (D) and quantification (E, F) for Cleaved Caspase 3 (CC3) and BCL2 revealed the decreased cell density in the M1 as a consequence of increased apoptosis $\left({ }^{* *} \mathrm{p}<0.01, \mathrm{n}=3\right)$. Western blot analysis $(\mathrm{G})$ and quantification $(\mathrm{H})$ revealed clear presence of CC3 in WT myocardial infarcts that could not be detected in $\mathrm{HZ}$ mice $(n=6)$. 


\section{Sema3A is Crucial for Constraining Monocyte Recruitment and Inducing Pro- Inflammatory MaCrophage ApOptosis}

In vitro chemotaxis experiments addressed whether sema3A could regulate monocyte migration. Isolated primary monocytes from $\mathrm{HZ}$ mice migrated significantly faster towards the chemoattractant $f$ MLP than WT monocytes ( $p<0.001$,Fig. $4 \mathrm{~A})$. In parallel, the presence of recombinant sema3A protein in the bottom of a Boyden chamber impeded the migration of WT monocytes ( $<<0.05$, Fig.4B). Bone marrow derived macrophages were polarized towards an anti-inflammatory (alternative- $\mathrm{M} \varphi, \mathrm{M} 2$ ) phenotype or towards a pro-inflammatory (classical-M $\varphi, \mathrm{M} 1$ ) phenotype ${ }^{21}$, prior to stimulation with recombinant Sema3A. Stimulation with recombinant Sema3A of the polarized cells resulted in a visible decrease in cell density

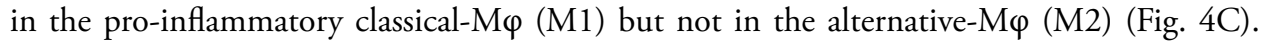
Furthermore, stimulation with Sema3A significantly increased the levels of apoptotic markers cleaved caspase-3 (CC3) and BCL2 in the classical-M $\varphi$ but not in alternative-M $\varphi(\mathrm{p}<0.01$, Fig. 4D-E). Finally, Sema HZ mice had no detectable CC3 protein expression in the infarcted area, which was detectable in the infarcts of WT mice at 14 days post MI (Fig. 4F).
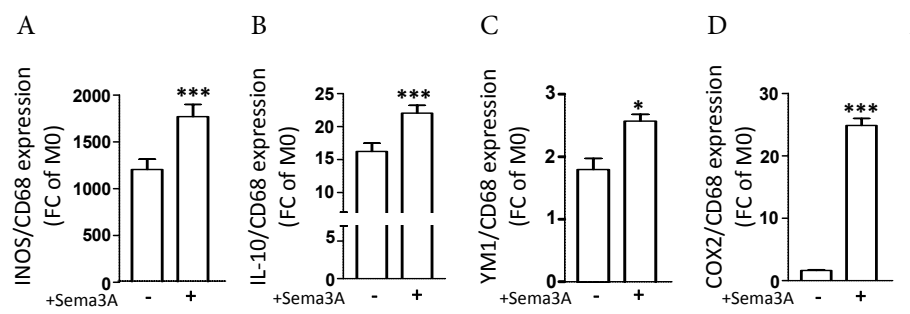

$\mathrm{E}$
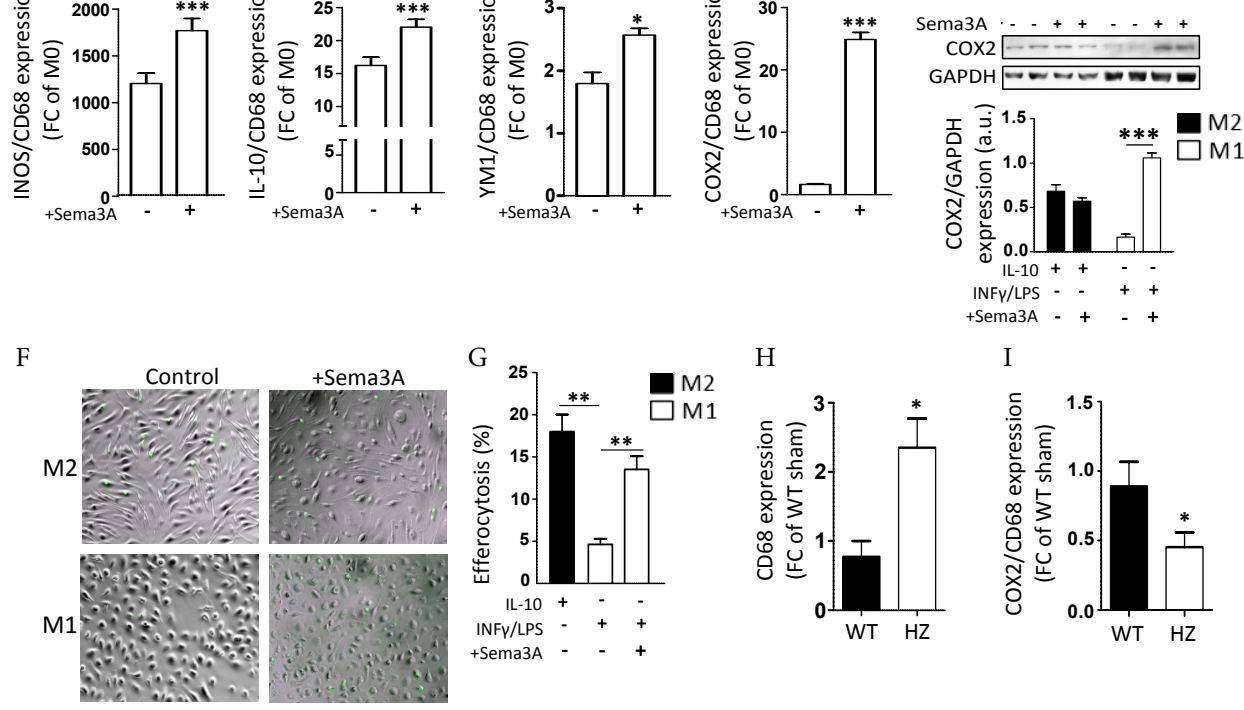

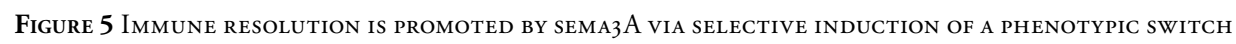

IN PRO-INFLAMMATORY MACROPHAGES TOWARDS RESOLUTION-PHASE-MACROPHAGES.

Bone Marrow Derived Macrophages were isolated and polarized for 24 hours towards M1 with and without the presence of sema3A. (A-C) The expression of iNOS, IL-10 and YM1 increased significantly in response to stimulation with sema3A $\left({ }^{*} \mathrm{p}<0.05,{ }^{* * *} \mathrm{p}<0.001, \mathrm{n}=3\right.$ ). Interestingly, the addition of sema3A resulted in a marked induction of COX2 transcript levels (D) and protein levels $(\mathrm{E})\left({ }^{* *} \mathrm{p}<0.001, \mathrm{n}=3\right)$. Clearance of apoptotic cells by means of efferocytosis was assessed in vitro. Fluorescently labeled apoptotic Jurkat-cells were fed to M2 and M1 with and without the presence of sema3A. As expected, M2 were significantly better at clearing apoptotic Jurkat-cells than M1 (F, G). Remarkably, addition of sema3A to M1 resulted in a significant increase in the percentage of efferocytotic cells $(\mathrm{F}, \mathrm{G})\left({ }^{* *} \mathrm{p}<0.01, \mathrm{n}=3\right)$. All experiments were repeated at least twice. The increased expression of COX2 in the presence of sema3A was also apparent in in vivo cardiac tissue, while the level of CD68 positivity was diminished $(\mathrm{H}$, I) $\left({ }^{*} \mathrm{p}<0.05\right)$ 


\section{Sema3A Promotes the Transition of Classically Activated Macrophages towards \\ RESOLUTION}

Resolution-phase macrophages are neither classical-M $\varphi$ nor alternative- $\mathrm{M} \varphi$ but a hybrid of both, and are characterized by the expression of inducible cyclooxygenase (COX2) and iNOS ${ }^{22}$. Stimulation of classical-M $\varphi$ (M1) with recombinant Sema3A significantly increased the transcript expression of M $\varphi$-markers i-NOS, IL-10, YM-1 and COX-2 (Fig. 5A-D). Furthermore, Sema3A stimulation increased COX2 protein levels in the pro-inflammatory

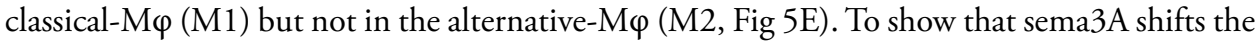
function of classical-M $\varphi$ towards resolution efferocytosis, which is crucial for correct infarct healing ${ }^{23,24}$, was assessed. Alternative-M $\varphi$ are better at clearing dying cells than classical$\mathrm{M} \varphi$ however, in the presence of recombinant sema3A classical-M $\varphi$ increased significantly their efferocytotic capabilities ( $\mathrm{p}<0.01$, Fig 5F-G). Finally, COX2 levels were significantly lower in infarcted cardiac tissue of Sema3A HZ as compared to WT mice, despite higher levels of CD68 (p<0.05,Fig. 5-H-I).

\section{Discussion}

The present study demonstrates that sema3A is imperative for proper myocardial wound healing. It is the first study to demonstrate a role for sema3A in promoting the resolution of inflammation after AMI. The recruitment of monocytes is of critical importance in the wound healing response following myocardial injury but restraining the flow of monocytes is equally needed in order to avoid excessive inflammation ${ }^{25}$. Sema3A regulates the inflammatory phase following myocardial injury by curbing the flow of recruited cells but also promoting the transition of classical-M $\varphi$ to resolution or alternative- $\mathrm{M} \varphi$.

Recently, Hou et al demonstrated that sema3A induces vascular permeability in cerebral ischemia-induced brain damage via the neuropilin-2/VEGR1 receptor complex ${ }^{26}$. In addition, Sema3A also competes with VEGF, hence affects vascular permeability during angiogenesis ${ }^{27}$. Despite cardiac ischemia initiating changes in vascular permeability and angiogenesis, the reduced sema3A in the $\mathrm{HZ}$ mice did not affect these processes. Sema $3 \mathrm{~A}$ has not previously been ascribed a role in resolving inflammation, though Sema3A has been shown to limit the recruitment of tumor-associated macrophages, restricting angiogenesis and restoring antitumor immunity ${ }^{28}$. In this study we show that Sema3A promotes the resolution of inflammation by regulating monocyte/macrophage function in 4 ways: (1) limiting the recruitment of monocytes, (2) promoting the apoptosis of classical-M $\varphi$ (M1) and (3) stimulating their transition to resolution-phase macrophages thereby (4) enhancing efferocytosis (Fig. 6). Though it is accepted that alternative- $\mathrm{M} \varphi$, along with resolution- $\mathrm{M} \varphi$ are critical for the transition to repair, little is still known about the local factors that mediate the shift. Recently IRF5 and NR4a-1 were shown to be critical in promoting the transition of macrophages towards resolution ${ }^{5,29}$, however more is known about the signals coming from T-cell subsets that promote repair such as IL-13 ${ }^{30}$ and thymosin beta ${ }^{4,31}$. Here we show that sema3A is vital for regulating cardiac monocyte/macrophage function in response to ischemic or virus induced myocardial injury. By encouraging a shift towards immune resolution, sema3A helps to maintain cardiac function. Sema3A may therefore be of therapeutic value not only as an anti-inflammatory agent in autoimmune diseases and cancer but potentially in preventing the development of heart failure by limiting adverse cardiac remodeling. 


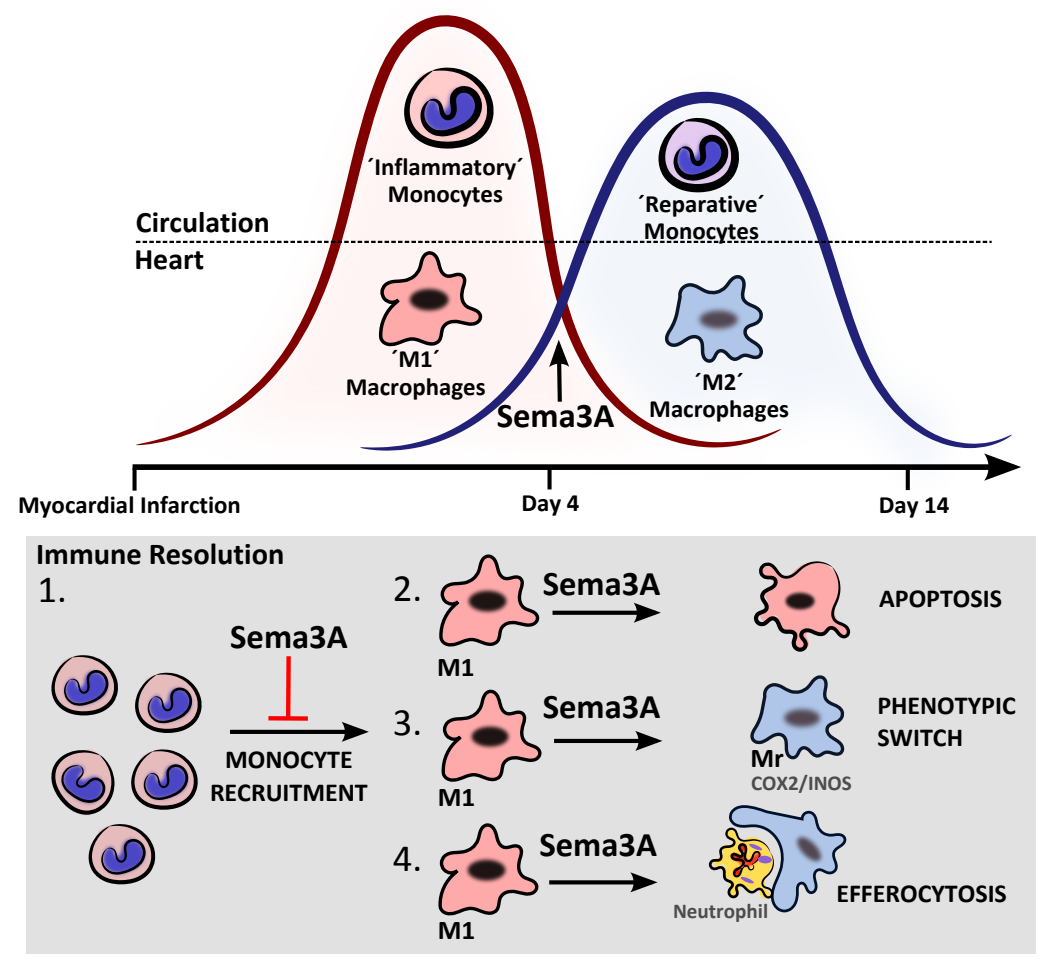

Figure 6 Sema3A promotes immune resolution.

Schematic overview of how sema3A promotes immune resolution on four different levels. Presence of sema3A in the border zone (1) prohibits excessive immune cell recruitment to the infarct. (2) Sema3A in the infarct promotes the clearance of inflammation by inducing apoptosis in M1 macrophages (3), promotes a phenotypic shift of M1cells towards resolution $(\mathrm{Mr})$ and (4) enhances efferocytosis in M1 cells. 


\section{REFERENCES}

1 Joggerst SJ, Hatzopoulos AK. Stem cell therapy for cardiac repair: Benefits and barriers. Expert reviews in molecular medicine. 2009;11:e20

2 Sutton MG, Sharpe N. Left ventricular remodeling after myocardial infarction: Pathophysiology and therapy. Circulation. 2000;101:2981-2988

3 Frangogiannis NG. The immune system and cardiac repair. Pharmacol Res. 2008;58:88-111

4 Nahrendorf M, Pittet MJ, Swirski FK. Monocytes: Protagonists of infarct inflammation and repair after myocardial infarction. Circulation. 2010;121:2437-2445

5 Hilgendorf I, Gerhardt LM, Tan TC, Winter C, Holderried TA, Chousterman BG, Iwamoto Y, Liao R, Zirlik A, Scherer-Crosbie M, Hedrick CC, Libby P, Nahrendorf M, Weissleder R, Swirski FK. Ly-6chigh monocytes depend on nr4a1 to balance both inflammatory and reparative phases in the infarcted myocardium. Circulation research. 2014;114:1611-1622

6 Luo Y, Raible D, Raper JA. Collapsin: A protein in brain that induces the collapse and paralysis of neuronal growth cones. Cell. 1993;75:217-227

7 Behar O, Golden JA, Mashimo H, Schoen FJ, Fishman MC. Semaphorin iii is needed for normal patterning and growth of nerves, bones and heart. Nature. 1996;383:525-528

8 Cora D, Astanina E, Giraudo E, Bussolino F. Semaphorins in cardiovascular medicine. Trends in molecular medicine. 2014;20:589-598

9 Delaire S, Billard C, Tordjman R, Chedotal A, Elhabazi A, Bensussan A, Boumsell L. Biological activity of soluble cd100. li. Soluble cd100, similarly to h-semaiii, inhibits immune cell migration. J Immunol. 2001;166:4348-4354

10 Fantin A, Maden CH, Ruhrberg C. Neuropilin ligands in vascular and neuronal patterning. Biochem Soc Trans. 2009;37:1228-1232

11 Vieira JM, Schwarz Q, Ruhrberg C. Role of the neuropilin ligands vegf164 and sema3a in neuronal and vascular patterning in the mouse. Novartis Found Symp. 2007;283:230-235; discussion 235-241

12 Chakraborty G, Kumar S, Mishra R, Patil TV, Kundu GC. Semaphorin 3a suppresses tumor growth and metastasis in mice melanoma model. PLoS One. 2012;7:e33633

13 Negi O, Tominaga M, Tengara S, Kamo A, Taneda K, Suga Y, Ogawa H, Takamori K. Topically applied semaphorin 3a ointment inhibits scratching behavior and improves skin inflammation in $\mathrm{nc} / \mathrm{nga}$ mice with atopic dermatitis. J Dermatol Sci. 2012;66:37-43

14 Catalano A. The neuroimmune semaphorin-3a reduces inflammation and progression of experimental autoimmune arthritis. J Immunol. 2010;185:6373-6383

15 Ranganathan P, Jayakumar C, Mohamed R, Weintraub NL, Ramesh G. Semaphorin 3a inactivation suppresses ischemia-reperfusion-induced inflammation and acute kidney injury. Am J Physiol Renal Physiol. 2014;307:F183-194

16 Lepelletier $\mathrm{Y}$, Lecourt S, Renand A, Arnulf B, Vanneaux V, Fermand JP, Menasche P, Domet T, Marolleau JP, Hermine O, Larghero J. Galectin-1 and semaphorin-3a are two soluble factors conferring t-cell immunosuppression to bone marrow mesenchymal stem cell. Stem Cells Dev. 2010;19:10751079

17 Moretti S, Procopio A, Lazzarini R, Rippo MR, Testa R, Marra M, Tamagnone L, Catalano A. Semaphorin3a signaling controls fas (cd95)-mediated apoptosis by promoting fas translocation into lipid rafts. Blood. 2008;111:2290-2299

18 Lepelletier Y, Moura IC, Hadj-Slimane R, Renand A, Fiorentino S, Baude C, Shirvan A, Barzilai A, Hermine O. Immunosuppressive role of semaphorin-3a on t cell proliferation is mediated by inhibition of actin cytoskeleton reorganization. Eur J Immunol. 2006;36:1782-1793

19 Catalano A, Caprari P, Moretti S, Faronato M, Tamagnone L, Procopio A. Semaphorin-3a is expressed by tumor cells and alters t-cell signal transduction and function. Blood. 2006;107:3321-3329

20 Chen RH, Li YG, Jiao KL, Zhang PP, Sun Y, Zhang LP, Fong XF, Li W, Yu Y. Overexpression of sema3a in myocardial infarction border zone decreases vulnerability of ventricular tachycardia post-myocardial infarction in rats. J Cell Mol Med. 2013;17:608-616 Mantovani A, Sica A, Locati M. Macrophage polarization comes of age. Immunity. 2005;23:344-346 Bystrom J, Evans I, Newson J, Stables M, Toor I, van Rooijen N, Crawford M, Colville-Nash P, Farrow $\mathrm{S}$, Gilroy DW. Resolution-phase macrophages possess a unique inflammatory phenotype that is controlled by camp. Blood. 2008;112:4117-4127

23 Wan E, Yeap XY, Dehn S, Terry R, Novak M, Zhang S, Iwata S, Han X, Homma S, Drosatos K, Lomasney J, Engman DM, Miller SD, Vaughan DE, Morrow JP, Kishore R, Thorp EB. Enhanced efferocytosis of apoptotic cardiomyocytes through myeloid-epithelial-reproductive tyrosine kinase links acute 
inflammation resolution to cardiac repair after infarction. Circulation research. 2013;113:1004-1012

24 Park YJ, Liu G, Lorne EF, Zhao X, Wang J, Tsuruta Y, Zmijewski J, Abraham E. Pai-1 inhibits neutrophil efferocytosis. Proc Natl Acad Sci U S A. 2008;105:11784-11789

25. Dutta $P$, Nahrendorf M. Monocytes in myocardial infarction. Arteriosclerosis, thrombosis, and vascular biology. 2015;35:1066-1070

26 Hou ST, Nilchi L, Li X, Gangaraju S, Jiang SX, Aylsworth A, Monette R, Slinn J. Semaphorin3a elevates vascular permeability and contributes to cerebral ischemia-induced brain damage. Sci Rep. 2015;5:7890

27 Acevedo LM, Barillas S, Weis SM, Gothert JR, Cheresh DA. Semaphorin 3a suppresses vegf-mediated angiogenesis yet acts as a vascular permeability factor. Blood. 2008;111:2674-2680

28 Casazza A, Laoui D, Wenes M, Rizzolio S, Bassani N, Mambretti M, Deschoemaeker S, Van Ginderachter JA, Tamagnone L, Mazzone M. Impeding macrophage entry into hypoxic tumor areas by sema3a/nrp1 signaling blockade inhibits angiogenesis and restores antitumor immunity. Cancer cell. 2013;24:695709

29 Courties G, Heidt T, Sebas M, Iwamoto Y, Jeon D, Truelove J, Tricot B, Wojtkiewicz G, Dutta P, Sager HB, Borodovsky A, Novobrantseva T, Klebanov B, Fitzgerald K, Anderson DG, Libby P, Swirski FK, Weissleder $R$, Nahrendorf $M$. In vivo silencing of the transcription factor irf5 reprograms the macrophage phenotype and improves infarct healing. Journal of the American College of Cardiology. 2014;63:15561566

30 Hofmann U, Knorr S, Vogel B, Weirather J, Frey A, Ertl G, Frantz S. Interleukin-13 deficiency aggravates healing and remodeling in male mice after experimental myocardial infarction. Circulation. Heart $f$ ailure. 2014; 7:822-830

31 Evans MA, Smart N, Dube KN, Bollini S, Clark JE, Evans HG, Taams LS, Richardson R, Levesque M, Martin P, Mills K, Riegler J, Price AN, Lythgoe MF, Riley PR. Thymosin beta4-sulfoxide attenuates inflammatory cell infiltration and promotes cardiac wound healing. Nature communications. 2013;4:2081 


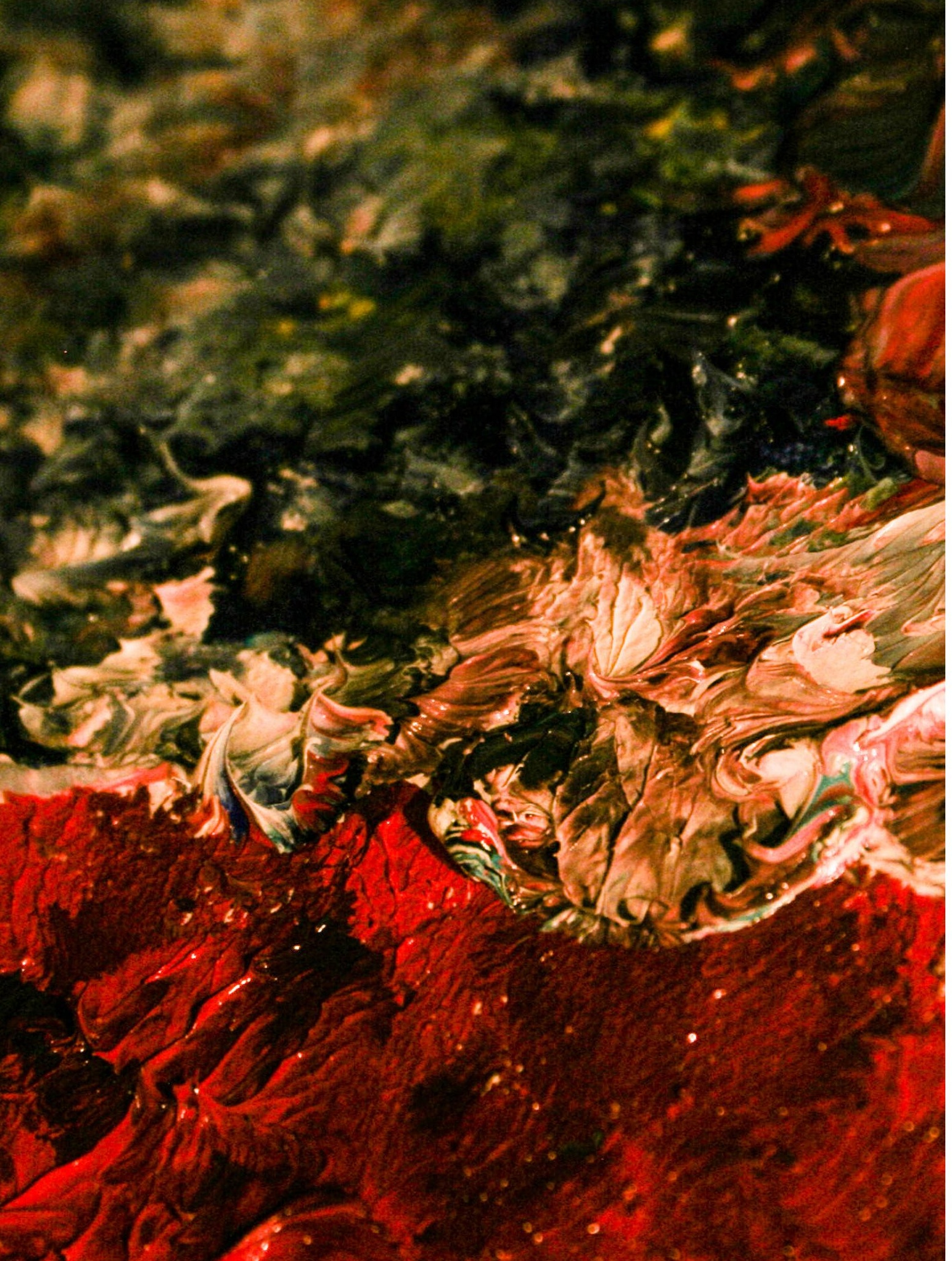

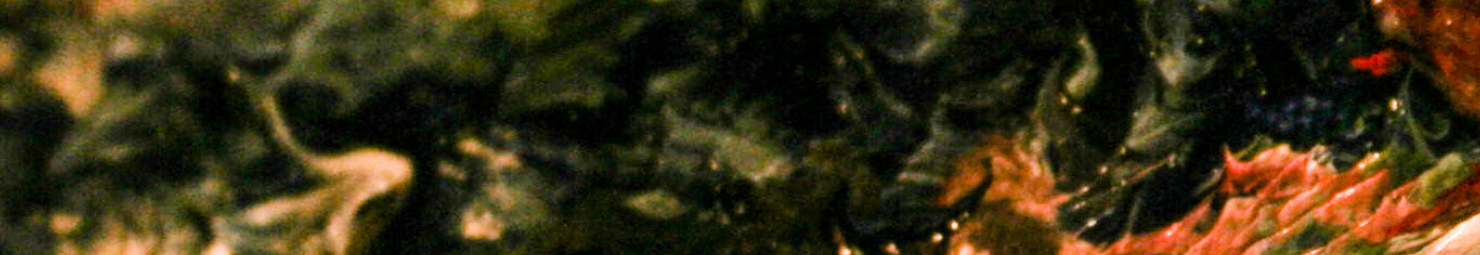

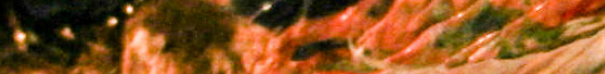

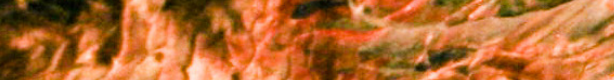
(4)

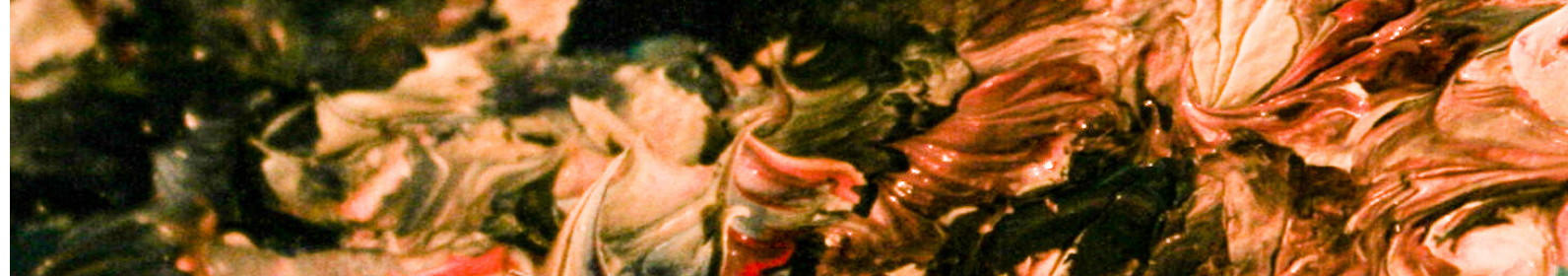
$\int_{-\infty} \int_{2}^{1}$ $\lim _{2}$

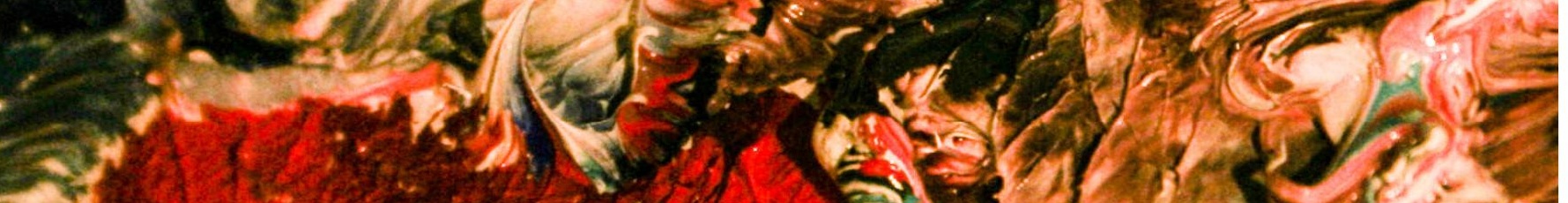
Esiction 


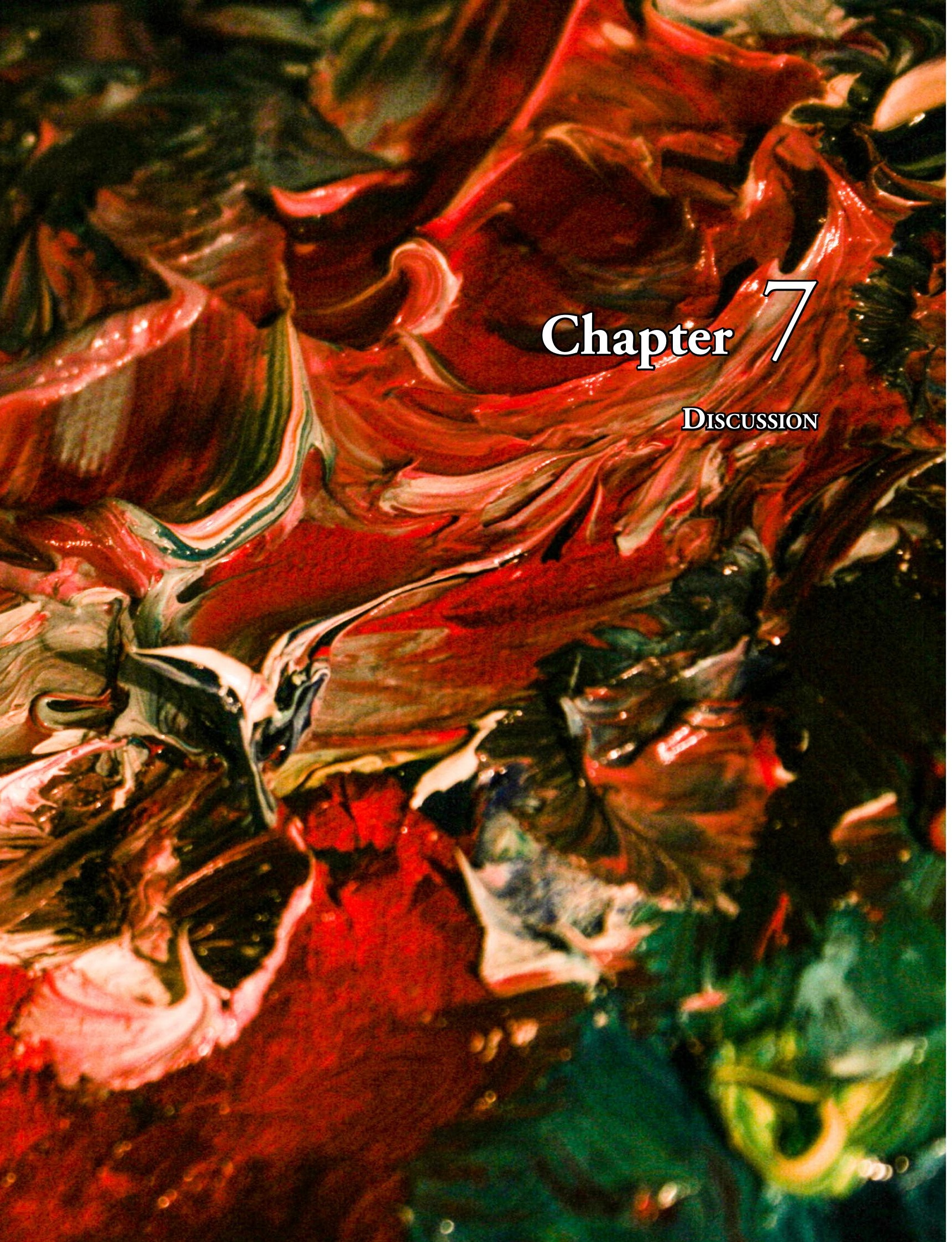


Vigilance of the extracellular space is vital for sensing the environmental changes that disturb homeostasis and ensures organismal survival. In response to injury however, the number of required immune cells needs to increase dramatically, requiring cell-mediated proteolytic extracellular matrix (ECM) degradation and remodeling. We now know that secreted or proteolytic released ECM products are not innocent waste products, rather they play a far more sophisticated role in regulating local immune responses. Not only do ECM components attract immune cells, they are also important for macrophage activation and $\mathrm{T}$ helper cell maturation ${ }^{1}$. Since the extracellular space of every organ has a very unique architecture attuned to its specific function, the local immune response between different organs may vary ${ }^{2}$. The aim of this thesis was to investigate the function of three components of this extracellular space during cardiac disease.

The contributions of ECM components Osteoglycin (OGN), SPARC and Semaphorin $3 \mathrm{~A}($ sema3A) in regulating cardiac inflammation are discussed in Chapter 3-5. Though all are present in the extracellular space, each of these proteins regulates cardiac inflammation in a different way. OGN is vital in enhancing the activation of immune cells upon tissue injury (Chapter 3). SPARC regulates the immune response by prohibiting aggravated immune cell recruitment by maintaining endothelial barrier properties and this can be targeted by the administration of recombinant protein, positively influencing the local cardiac immune response (Chapter 4). Presence of sema3A in the extracellular space allows for the clearance of pro-inflammatory macrophages by altering their properties and stimulating them to become apoptotic (Chapter 5). Finally, this thesis reveals that glycosylation creates different forms of the proteoglycan OGN and hence decides its cellular location and its subsequent function: either in the extracellular matrix promoting the alignment of collagen fibers or in the cell membrane enhancing TLR activation (Chapter 3).

\section{The Glycome as Regulator of Pattern Recognition Receptors Activation}

The development and preservation of complex organism like humans is an incredibly complex undertaking. Every essential biological process needs specific molecular structures for its execution. Information regarding the configuration of these specific molecular structures lies within the genome. However, when considering simple bacteria and higher eukaryotes, it is hard to imagine that a modest increase in the number of genes would allow for the dramatic jump in complexity between these organisms. Here, the evolutionary origination of glycans empowered the creation of new molecular entities that do not necessitate a direct genetic template ${ }^{3}$. These glycans are very important in controlling the appearance of both intracellular as well as extracellular proteins produced by the cell. The variation in glycan production as a consequence of the spatio-temporal expression of glycosyltransferases and glycosidase enzymes in the endoplasmic reticulum and golgi apparatus is immense. Whilst over 200 glycosylation enzymes have been recognized in the mammalian genome ${ }^{4}$, currently only 16 enzymes have been identified or cloned ${ }^{5}$. As about ninety-five percent of all secreted proteins are subjected to glycosylation ${ }^{6}$, there is a clear scientific need for unravelling this complex process and its biological implications. Collectively, glycans are the result of a complex biosynthetic pathway that is affected by hundreds of genetic and environmental factors. 
There is growing appreciation of the importance of glycosylation in diseases such as cancer ${ }^{7}$, alzheimer ${ }^{8}$, diabetes ${ }^{9}$, and autoimmune disease ${ }^{10}$. Also glycosylation contributes significantly to the pathogenesis of ageing by exacerbated inflammation ${ }^{11}$, in turn causing altered PRR responsiveness ${ }^{12}$. The close connection of the endoplasmic reticulum and golgi apparatus with the extracellular milieu makes this glycosylation machinery particularly well equipped for interacting with pathogens. Therefore, as glycans became more and more complex throughout evolution, vertebrates developed a phyloglycomic recognition system, such as the Toll-like receptors and C-type lectin receptors, to detect the glycans of lower organisms so as to tell apart self from non-self ${ }^{13}$. Unraveling the code of highly complex and extremely variable glycan structures is key as it may reveal tailored PRR activation that may lead to well-cut immune responses. Yet, as the regulation of glycan production and degradation is exceptionally intricate, this has been an extremely challenging undertaking. Not only the transcriptional regulation of glycosylation enzymes is imperative for glycan formation, also the availability of the essential molecular substrates is vital. Furthermore, because the cellular localization of key glycosylation enzymes can change due to environmental changes, glycan production is continuously changing and frequently associated with changing cellular phenotypes ${ }^{14}$.

Instead of working as an on/off switch, glycosylation allows for a continuously adapting machinery that contributes to protein structure and enables novel functions. Studies have shown that glycosylation can modify proteins by either enhancing their PRR receptor affinity or impeding PRR binding ${ }^{15-18}$. Moreover, upon matrix degradation in response to injury, proteolytic processing of ECM components can release previously masked epitopes making them available for receptor binding. Interaction of PRR with endogenous proteins may therefore contribute substantially to the immunological concept of 'self-versus nonself' and help to tailor the immune response. However the possible recognition of a broad range of endogenous, continuously evolving ligands by PRRs, challenges the existing theories explaining our immune system. Rather than giving fixed, consistent and well-defined responses as suggested by both the 'self-versus non-self' and 'Danger-model' theories, it is more probable that every immune response initiated by PRR-ligand interaction can generate a variety of modifiable responses that depend on the environmental appearance of the endogenous ligands at that given moment. Therefore the makeup of the extracellular space during diseases is critical in defining the type and intensity of the immune response.

Despite the cardiac phenotype in patients suffering from congenital glycosylation disorders ${ }^{19}$, very little is known about glycosylation in relation to cardiovascular disease. Many studies describing protein glycosylation use targeted approaches, commonly immunohistochemistry with monoclonal antibodies or lectins against specific glycan epitopes. While these targeted approaches have a relatively high specificity, the non-targeted approach using liquid chromatography tandem mass spectrometry (LC-MS/MS) provides the ability to systematically profile dynamic glycomes and uncover novel disease-associated (proteo)-glycans. This approach has yet to be fully applied for the identification of cardiac specific glycomes but offers hope for future biomarker and drug development in cardiovascular disease.

\section{Secreted Glycoproteins as Regulators of Immune Cell Recruitment}

Upon tissue damage chemokines and cytokines produced by resident immune cells activate the local endothelium of blood vessels. This local change in endothelial appearance 
is recognized by circulating immune cells and followed by their extravasation. While many secreted proteins residing in either the basement membrane or extracellular space interact with invading leukocytes facilitating their movement in the diseased tissue ${ }^{20}$, their remit as a protective barrier, in the form of the endothelial glycocalyx, has received limited attention. Nevertheless, the endothelial glycocalyx is an intricate structure, varying from $2-3 \mu \mathrm{m}$ in small arteries ${ }^{21}$ to $4.5 \mu \mathrm{m}$ in carotid arteries ${ }^{22}$, that is comprised of a negatively charged network of glycoproteins, glycolipids and proteoglycans. Shedding of this structure upon injury by extracellular proteases exposes adhesion molecules and promotes leukocyte extravasation ${ }^{23}$. Just as ECM composition is different from organ to organ, the appearance of the endothelial glycocalyx may also vary greatly depending on the vascular endothelial bed ${ }^{24-26}$. As the importance of the endothelial glycocalyx has been acknowledged for several cardiovascular diseases like diabetes ${ }^{27}$, coronary artery disease ${ }^{28}$, and atherosclerosis ${ }^{29}$, targeted therapeutic approaches directed at restoring glycocalyx integrity may hamper disease progression. As this structure is easily targetable via the circulation, manipulation of the endothelial glycocalyx may have great therapeutic implications for many diseases like heart failure (HF). Additionally, the detection of glycocalyx components in the circulation could have important prognostic value in HF patients. Certainly, the identification of SPARC as a trivial component of the cardiac microvascular glycocalyx, as described in this thesis, may serve as such a prognostic factor as recent studies show a significant increase in plasma SPARC levels in patients with diabetes and coronary artery disease ${ }^{30,31}$. Therefore, further identification of compositional changes in different vascular beds might serve as a detailed and specific biomarker pointing precisely at the injurious tissue and possibly the stage of the disease.

\section{Secreted Glycoproteins Promote Immune RESOLUTION}

Whereas targeting of the endothelial glycocalyx may restrain immune cell recruitment and HF progression, modulation of macrophage persistence might present another interesting

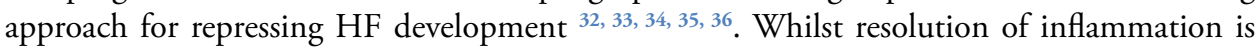
a vital process in wound healing ${ }^{37}$ its role in cardiac disease is rather unexplored. For proper wound healing to evolve, the initial inflammatory response has to shut down in order to allow for the reinstatement of the ECM and tissue remodeling ${ }^{38}$. Therefore, while the influx of pro-inflammatory monocytes and macrophages is vital in the early stages of myocardial infarct healing, a timely shift towards recruitment of anti-inflammatory monocytes and macrophages is key ${ }^{34,39}$. This shift can be promoted by either (1) the activation of immune suppressive cell populations, (2) soluble mediators that actively drive immune suppression, (3) the loss of proinflammatory stimuli or (4) induction of immune cell apoptosis ${ }^{40}$. Though there is substantial overlap in these pathways, they display the different levels at which immune resolution can be promoted. It has already been shown that loss of the balance between the pro- and antiinflammatory responses is occurring in critically ill patients ${ }^{41-43}$ and current advances emphasize the relevance and therapeutic potential of promoting immune resolution in myocardial infarct healing ${ }^{32,44}, 45$, however with limited transferability of this therapy to patients. By affecting all three of the aforementioned pathways, secreted protein sema3 A encourages the timely shift towards resolution of cardiac inflammation. Though precise identification of the sema3A protein epitope that is responsible for specific macrophage phenotype manipulation in healing infarcts is needed, the clinical potential of small peptides is much more promising 
than gene-delivery therapies. As HF progression is characterized by sustained inflammation

${ }^{46}$, promoting resolution of inflammation generates an extremely interesting new therapeutic avenue, especially as lower levels of pro-resolving and anti-inflammatory lipoxins are clearly associated with higher severity of $\mathrm{HF}^{47}$.

\section{Conclusions and Future Perspectives}

This thesis attempts to acknowledge the complexity of the immune system during HF progression by expanding on its close interaction with the cardiac extracellular compartment and the many modalities at which secreted proteins can regulate inflammation in cardiac disease. Despite the existing therapies, the clinical outcome of patients with chronic HF is still very poor and extremely difficult to predict. Many studies show that cytokines are progressively elevated in HF patients with poor prognosis and point to the important role of the immune system in the propagation of $\mathrm{HF}^{48-51}$. However, therapies targeting these cytokines are very unspecific and have therefore been largely unsuccessful thus far ${ }^{52-54}$. This also exposes limited appreciation for the intricacy of the immune system in chronic HF development, resulting in an oversimplified approach to treatment. Not only does this thesis show that these secreted proteins play a role in activating or alarming the immune system, they can also modulate immune cell recruitment and promote the resolution of inflammation (Figure 1). This specific and multi-layered regulation of immunity by the extracellular proteo-glycomes provides novel insights that may lead to specific therapeutic tailoring of immune responses in cardiac disease.

Firstly, by detecting specific protein appearances as markers for the underlying tissuespecific pathophysiological processes may help tremendously in understanding the regulatory potential of secreted proteins in immune responses during cardiac diseases. Further unraveling the glycosylation differences in cardiac disease may create an immense repertoire of novel and well-tailored therapeutic targets. By applying the latest glycoproteomics techniques in specific animal models and HF patients, unique disease specific proteo-glycomes can be identified and related to the underlying pathophysiology. This may represent the future in our quest to improve treatment of HF patients. 


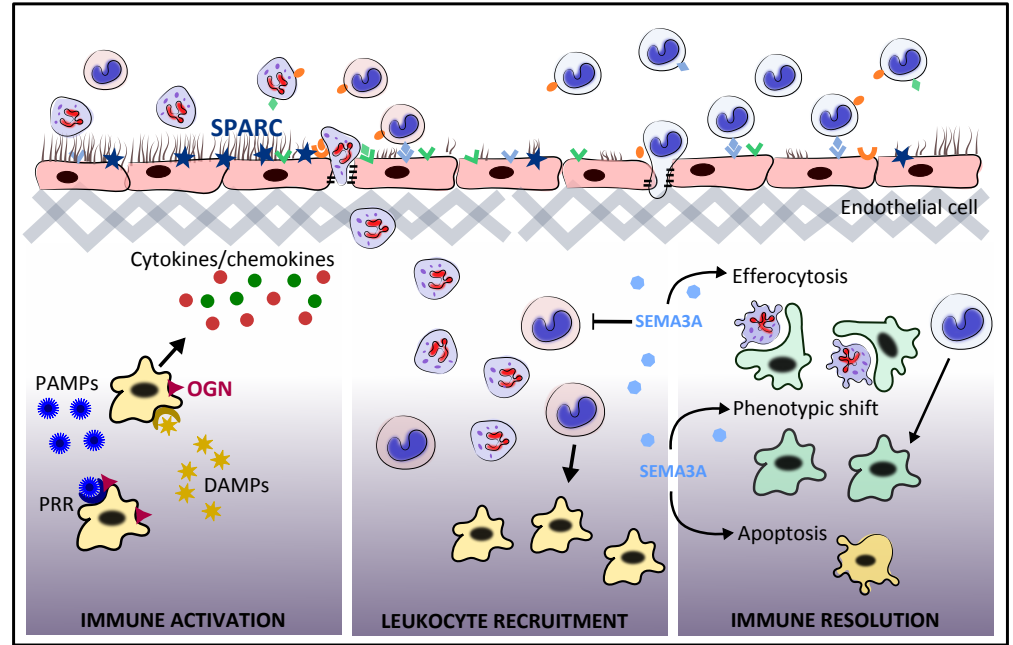

Figure 1 Secreted Glycoproteins and Proteoglycans Orchestrate Inflammation in Cardiac Disease. This illustration represents the importance of three independent matrix elements in innate immunity. While Osteoglycin (OGN) enhances immune activation with subsequent aggravated immune cell recruitment, SPARC restrains immune cell recruitment at the level of the endothelium. As part of the endothelial glycocalyx SPARC prohibits leukocyte endothelial interactions thereby prohibiting leukocyte extravasation and subsequent cardiac inflammation. Finally, semaphorin3A (sema3A) plays a vital role in clearing the massively infiltrated immune cells by restraining excessive leukocyte recruitment and by diminishing the presence of classical-MФ(M1) thru the induction of apoptosis and stimulating their transition to resolution-phase macrophages thereby enhancing efferocytosis .

PRR : Pathogen Recognition Receptor, DAMP : Danger Associated Molecular Pattern, PAMP : Pathogen Associated Molecular Pattern 


\section{REFERENCES}

1 Lu P, Weaver VM, Werb Z. The extracellular matrix: A dynamic niche in cancer progression. J Cell Biol. 2012;196:395-406

2 Raz E. Organ-specific regulation of innate immunity. Nat Immunol. 2007;8:3-4

3 Lauc G, Kristic J, Zoldos V. Glycans - the third revolution in evolution. Front Genet. 2014;5:145

4 Jaeken J, Hennet T, Freeze HH, Matthijs G. On the nomenclature of congenital disorders of glycosylation (cdg). Journal of inherited metabolic disease. 2008;31:669-672

5 Spiro RG. Protein glycosylation: Nature, distribution, enzymatic formation, and disease implications of glycopeptide bonds. Glycobiology. 2002;12:43R-56R

6 Lam PV, Goldman R, Karagiannis K, Narsule T, Simonyan V, Soika V, Mazumder R. Structure-based comparative analysis and prediction of n-linked glycosylation sites in evolutionarily distant eukaryotes. Genomics, proteomics \& bioinformatics. 2013;11:96-104

7 Christiansen MN, Chik J, Lee L, Anugraham M, Abrahams JL, Packer NH. Cell surface protein glycosylation in cancer. Proteomics. 2014;14:525-546

8 Schedin-Weiss S, Winblad B, Tjernberg LO. The role of protein glycosylation in alzheimer disease. FEBS J. 2014;281:46-62

9 Laczy B, Hill BG, Wang K, Paterson AJ, White CR, Xing D, Chen YF, Darley-Usmar V, Oparil S, Chatham JC. Protein o-glcnacylation: A new signaling paradigm for the cardiovascular system. Am J Physiol Heart Circ Physiol. 2009;296:H13-28

10 Delves PJ. The role of glycosylation in autoimmune disease. Autoimmunity. 1998;27:239-253

11 Dall'Olio F, Vanhooren V, Chen CC, Slagboom PE, Wuhrer M, Franceschi C. N-glycomic biomarkers of biological aging and longevity: A link with inflammaging. Ageing Res Rev. 2013;12:685-698

12 Shaw AC, Goldstein DR, Montgomery RR. Age-dependent dysregulation of innate immunity. Nat Rev Immunol. 2013;13:875-887

13 Medzhitov R, Janeway $\mathrm{C}$, Jr. The toll receptor family and microbial recognition. Trends Microbiol. 2000;8:452-456

14 Marth JD, Grewal PK. Mammalian glycosylation in immunity. Nature reviews. Immunology. 2008;8:874-887

15 Rocuts F, Ma Y, Zhang X, Gao W, Yue Y, Vartanian T, Wang H. Carbon monoxide suppresses membrane expression of tIr4 via myeloid differentiation factor-2 in betatc3 cells. Journal of immunology. 2010;185:2134-2139

16 Bloem K, Vuist IM, van der Plas AJ, Knippels LM, Garssen J, Garcia-Vallejo JJ, van Vliet SJ, van Kooyk $\mathrm{Y}$. Ligand binding and signaling of dendritic cell immunoreceptor (dcir) is modulated by the glycosylation of the carbohydrate recognition domain. PloS one. 2013;8:e66266

17 Barata TS, Teo I, Brocchini S, Zloh M, Shaunak S. Partially glycosylated dendrimers block md-2 and prevent tIr4-md-2-Ips complex mediated cytokine responses. PLoS computational biology. 2011;7:e1002095

18 Yang Y, Liu B, Dai J, Srivastava PK, Zammit DJ, Lefrancois L, Li Z. Heat shock protein gp96 is a master chaperone for toll-like receptors and is important in the innate function of macrophages. Immunity. 2007;26:215-226

19 Gehrmann J, Sohlbach K, Linnebank M, Bohles HJ, Buderus S, Kehl HG, Vogt J, Harms E, Marquardt T. Cardiomyopathy in congenital disorders of glycosylation. Cardiol Young. 2003;13:345-351

20 Murphy-Ullrich JE. The de-adhesive activity of matricellular proteins: Is intermediate cell adhesion an adaptive state? J Clin Invest. 2001;107:785-790

21 Mozaffarian D, Benjamin EJ, Go AS, Arnett DK, Blaha MJ, Cushman M, de Ferranti S, Despres JP, Fullerton HJ, Howard VJ, Huffman MD, Judd SE, Kissela BM, Lackland DT, Lichtman JH, Lisabeth LD, Liu S, Mackey RH, Matchar DB, McGuire DK, Mohler ER, 3rd, Moy CS, Muntner P, Mussolino ME, Nasir K, Neumar RW, Nichol G, Palaniappan L, Pandey DK, Reeves MJ, Rodriguez CJ, Sorlie PD, Stein J, Towfighi A, Turan TN, Virani SS, Willey JZ, Woo D, Yeh RW, Turner MB. Heart disease and stroke statistics--2015 update: A report from the american heart association. Circulation. 2015;131:e29-322

22 Go AS, Mozaffarian D, Roger VL, Benjamin EJ, Berry JD, Blaha MJ, Dai S, Ford ES, Fox CS, Franco S, Fullerton HJ, Gillespie C, Hailpern SM, Heit JA, Howard VJ, Huffman MD, Judd SE, Kissela BM, Kittner SJ, Lackland DT, Lichtman JH, Lisabeth LD, Mackey RH, Magid DJ, Marcus GM, Marelli A, Matchar DB, McGuire DK, Mohler ER, 3rd, Moy CS, Mussolino ME, Neumar RW, Nichol G, Pandey DK, Paynter NP, Reeves MJ, Sorlie PD, Stein J, Towfighi A, Turan TN, Virani SS, Wong ND, Woo D, Turner MB. Executive summary: Heart disease and stroke statistics--2014 update: A report from the american heart 
association. Circulation. 2014;129:399-410 Discov Today Dis Models. 2011;8:57-62

Lim YC, Garcia-Cardena G, Allport JR, Zervoglos M, Connolly AJ, Gimbrone MA, Jr., Luscinskas FW. Heterogeneity of endothelial cells from different organ sites in t-cell subset recruitment. The American journal of pathology. 2003;162:1591-1601

Aird WC. Endothelial cell heterogeneity. Cold Spring Harbor perspectives in medicine. 2012;2:a006429 Aird WC. Phenotypic heterogeneity of the endothelium: li. Representative vascular beds. Circ Res. 2007;100:174-190

Perrin RM, Harper SJ, Bates DO. A role for the endothelial glycocalyx in regulating microvascular permeability in diabetes mellitus. Cell biochemistry and biophysics. 2007;49:65-72

Lemkes BA, Nieuwdorp M, Hoekstra JB, Holleman F. The glycocalyx and cardiovascular disease in diabetes: Should we judge the endothelium by its cover? Diabetes Technol Ther. 2012;14 Suppl 1:S310

Koo A, Dewey CF, Jr., Garcia-Cardena G. Hemodynamic shear stress characteristic of atherosclerosisresistant regions promotes glycocalyx formation in cultured endothelial cells. American journal of physiology. Cell physiology. 2013;304:C137-146

Takahashi M, Nagaretani H, Funahashi T, Nishizawa H, Maeda N, Kishida K, Kuriyama H, Shimomura I, Maeda K, Hotta K, Ouchi N, Kihara S, Nakamura T, Yamashita S, Matsuzawa Y. The expression of sparc in adipose tissue and its increased plasma concentration in patients with coronary artery disease. Obesity research. 2001;9:388-393

Wu D, Li L, Yang M, Liu H, Yang G. Elevated plasma levels of sparc in patients with newly diagnosed type 2 diabetes mellitus. Eur J Endocrinol. 2011;165:597-601

Courties G, Heidt T, Sebas M, Iwamoto Y, Jeon D, Truelove J, Tricot B, Wojtkiewicz G, Dutta P, Sager HB, Borodovsky A, Novobrantseva T, Klebanov B, Fitzgerald K, Anderson DG, Libby P, Swirski FK, Weissleder $R$, Nahrendorf $M$. In vivo silencing of the transcription factor irf5 reprograms the macrophage phenotype and improves infarct healing. Journal of the American College of Cardiology. 2014;63:1556-1566

Nahrendorf M. Macrophages in the infarct: Fiery friends or friendly fire? J Mol Cell Cardiol. 2012;53:591-592

Nahrendorf M, Pittet MJ, Swirski FK. Monocytes: Protagonists of infarct inflammation and repair after myocardial infarction. Circulation. 2010;121:2437-2445

Romson JL, Hook BG, Kunkel SL, Abrams GD, Schork MA, Lucchesi BR. Reduction of the extent of ischemic myocardial injury by neutrophil depletion in the dog. Circulation. 1983;67:1016-1023 Jolly SR, Kane WJ, Hook BG, Abrams GD, Kunkel SL, Lucchesi BR. Reduction of myocardial infarct size by neutrophil depletion: Effect of duration of occlusion. Am Heart J. 1986;112:682-690

Mahdavian Delavary B, van der Veer WM, van Egmond M, Niessen FB, Beelen RH. Macrophages in skin injury and repair. Immunobiology. 2011;216:753-762

Nahrendorf M, Swirski FK, Aikawa E, Stangenberg L, Wurdinger T, Figueiredo JL, Libby P, Weissleder $\mathrm{R}$, Pittet MJ. The healing myocardium sequentially mobilizes two monocyte subsets with divergent and complementary functions. The Journal of experimental medicine. 2007;204:3037-3047 Kain V, Prabhu SD, Halade GV. Inflammation revisited: Inflammation versus resolution of inflammation following myocardial infarction. Basic research in cardiology. 2014;109:444

Ayala A, Chung CS, Grutkoski PS, Song GY. Mechanisms of immune resolution. Critical care medicine. 2003;31:S558-571

Angele MK, Knoferl MW, Ayala A, Albina JE, Cioffi WG, Bland KI, Chaudry IH. Trauma-hemorrhage delays wound healing potentially by increasing pro-inflammatory cytokines at the wound site. Surgery. 1999;126:279-285

Rico RM, Ripamonti R, Burns AL, Gamelli RL, DiPietro LA. The effect of sepsis on wound healing. The Journal of surgical research. 2002;102:193-197

Angele MK, Nitsch SM, Hatz RA, Angele P, Hernandez-Richter T, Wichmann MW, Chaudry IH, Schildberg FW. L-arginine: A unique amino acid for improving depressed wound immune function following hemorrhage. European surgical research. Europaische chirurgische Forschung. Recherches chirurgicales europeennes. 2002;34:53-60

Majmudar MD, Keliher EJ, Heidt T, Leuschner F, Truelove J, Sena BF, Gorbatov R, Iwamoto Y, Dutta P, Wojtkiewicz G, Courties G, Sebas M, Borodovsky A, Fitzgerald K, Nolte MW, Dickneite G, Chen JW, Anderson DG, Swirski FK, Weissleder R, Nahrendorf M. Monocyte-directed rnai targeting ccr2 improves infarct healing in atherosclerosis-prone mice. Circulation. 2013;127:2038-2046

Etzrodt M, Cortez-Retamozo V, Newton A, Zhao J, Ng A, Wildgruber M, Romero P, Wurdinger T, 
Xavier R, Geissmann F, Meylan E, Nahrendorf M, Swirski FK, Baltimore D, Weissleder R, Pittet MJ. Regulation of monocyte functional heterogeneity by mir-146a and relb. Cell reports. 2012;1:317-324 Anker SD, von Haehling S. Inflammatory mediators in chronic heart failure: An overview. Heart. 2004;90:464-470

47 Reina-Couto M, Carvalho J, Valente MJ, Vale L, Afonso J, Carvalho F, Bettencourt P, Sousa T, AlbinoTeixeira A. Impaired resolution of inflammation in human chronic heart failure. European journal of clinical investigation. 2014;44:527-538

48 Levine B, Kalman J, Mayer L, Fillit HM, Packer M. Elevated circulating levels of tumor necrosis factor in severe chronic heart failure. The New England journal of medicine. 1990;323:236-241

49 Aukrust P, Ueland T, Lien E, Bendtzen K, Muller F, Andreassen AK, Nordoy I, Aass H, Espevik T, Simonsen S, Froland SS, Gullestad L. Cytokine network in congestive heart failure secondary to ischemic or idiopathic dilated cardiomyopathy. The American journal of cardiology. 1999;83:376-382

50 Mann DL, Young JB. Basic mechanisms in congestive heart failure. Recognizing the role of proinflammatory cytokines. Chest. 1994;105:897-904

51 Yndestad A, Holm AM, Muller F, Simonsen S, Froland SS, Gullestad L, Aukrust P. Enhanced expression of inflammatory cytokines and activation markers in t-cells from patients with chronic heart failure. Cardiovascular research. 2003;60:141-146

52 Mann DL, McMurray JJ, Packer M, Swedberg K, Borer JS, Colucci WS, Djian J, Drexler H, Feldman A, Kober L, Krum H, Liu P, Nieminen M, Tavazzi L, van Veldhuisen DJ, Waldenstrom A, Warren M, Westheim A, Zannad F, Fleming T. Targeted anticytokine therapy in patients with chronic heart failure: Results of the randomized etanercept worldwide evaluation (renewal). Circulation. 2004;109:15941602

53 Kurrelmeyer KM, Michael LH, Baumgarten G, Taffet GE, Peschon JJ, Sivasubramanian N, Entman ML, Mann DL. Endogenous tumor necrosis factor protects the adult cardiac myocyte against ischemicinduced apoptosis in a murine model of acute myocardial infarction. Proceedings of the National Academy of Sciences of the United States of America. 2000;97:5456-5461

54 Chung ES, Packer M, Lo KH, Fasanmade AA, Willerson JT, Anti TNFTACHFI. Randomized, double-blind, placebo-controlled, pilot trial of infliximab, a chimeric monoclonal antibody to tumor necrosis factoralpha, in patients with moderate-to-severe heart failure: Results of the anti-tnf therapy against congestive heart failure (attach) trial. Circulation. 2003;107:3133-3140 

Heart failure (HF) is major public health issue and remains the number one cause of death in the world. It is characterized by an abnormal structure or function of the heart at rest accompanied by typical clinical symptoms such as shortness of breath, fatigue and fluid retention. The current therapeutic strategies are mainly supportive in fighting these clinical symptoms without having any evident effect of the underlying pathophysiology. Because $\mathrm{HF}$ is such a complex syndrome where many underlying etiologies may affect pericardium, myocardium, endocardium, cardiac valves, vasculature, or metabolism, the identification of new effective therapies has been very challenging these past decades.

This thesis described the importance of the extracellular environment on cardiac inflammation during HF development. Not only does this thesis emphasize that glycoproteins and proteoglycans exert regulatory functions in the extracellular space, it also expands this extracellular space to the vascular lining known as the endothelial glycocalyx. Importantly, this thesis highlights the significance of glycosylation, a post-translational process that adds onto the protein-core different forms of sugars (glycans), which tremendously increases the functional variability of the protein. As a result the ECM extends its biological functions beyond maintaining structural integrity to include cell adhesion, signal transduction, immunity, embryonic development and microbial recognition, hence regulate cardiac inflammation. The pathophysiological contribution of secreted proteins osteoglycin, SPARC and semaphorin $3 \mathrm{~A}$ on the expansion and maintenance of cardiac inflammation as a consequence of viral myocarditis or myocardial infarction are addressed. As the role of extracellular matrix proteins until now has mainly focused on its implication in cardiac fibrosis, we wondered whether these versatile protein could also affect cardiac inflammation. As immunity is the driving force behind many diseases we used two models to investigate the contribution of the immune system in heart failure. By looking at sterile inflammation versus non-sterile inflammation we tried to unravel the mysteries of extracellular matrix: an ever changing and diverse entity.

We first have explained the responsibilities of the immune system when facing exogenous threats. Intimate relations with both the cellular and extracellular component are vital and provide indispensable information to the immune system regarding these threats. Chapter 2 describes the role of this extracellular compartment in regulating vital processes like inflammation and fibrosis that follow tissue injury. Not only does this chapter emphasize the multiplicity and variability of this extracellular environment, it also emphasizes its potential for future therapeutic strategies. 
The conceivable implication of specific extracellular glycoproteins and proteoglycans is then discussed in Chapter 3, 4 and 5. Here we have shown experimental evidence for the modulatory effect on cardiac inflammation of three individual extracellular proteins either during virus or ischemia induced cardiac disease.

Proteoglycan Osteoglycin is important for providing information to immune system via pattern recognition receptors thereby enhancing its activity and subsequent cardiac inflammation during viral myocarditis. We revealed that Osteoglycin has a versatile appearance as a consequence of glycosylation, which correlates with the underlying pathophysiology process. Glycoprotein SPARC on the other hand revealed to be vital in the extracellular lining of the blood vessels known as the endothelial glycocalyx, where it regulates vascular permeability as well as leukocyte recruitment. We have demonstrated that lack of SPARC severely compromised the cardiac microvascular glycocalyx thereby dismantling its barrier functions. This results in increased cardiac inflammation in virus induced cardiac injury. Interestingly, we have proposed therapeutic potential by restoring the glycocalyx via exogenous administration of SPARC as this reduced leukocyte recruitment and vascular permeability hence cardiac inflammation. Finally we have identified the importance of a third extracellular component in regulating cardiac inflammation, glycoprotein semaphorin 3A. For this study we have used both the viral myocarditis model as well as the myocardial infarction model. We have shown that semaphorin $3 \mathrm{~A}$ reduced cardiac inflammation in both models by promoting immune resolution. While recruitment of neutrophils and monocytes is vital in the early stages of tissue injury, timely clearance is indispensable for adequate tissue healing. This thesis revealed that semaphorin $3 \mathrm{~A}$ specifically affects the polarization state of pro-inflammatory M1 macrophages. Also, semaphorin 3A particularly induced apoptosis in these pro-inflammatory M1 macrophages while not affecting the more anti-inflammatory macrophages phenotype.

In summary, this thesis presents important roles for secreted glycoproteins and proteoglycans during inflammation in heart disease. These fundamental findings do not only complement our understanding of cardiac disease development that leads to HF, it revealed universal interactions of the immune system with the extracellular milieu. Misleading the immune system by pharmacologically rewiring the information coming from the extracellular components may form the key for curing life threatening human diseases like HF. 


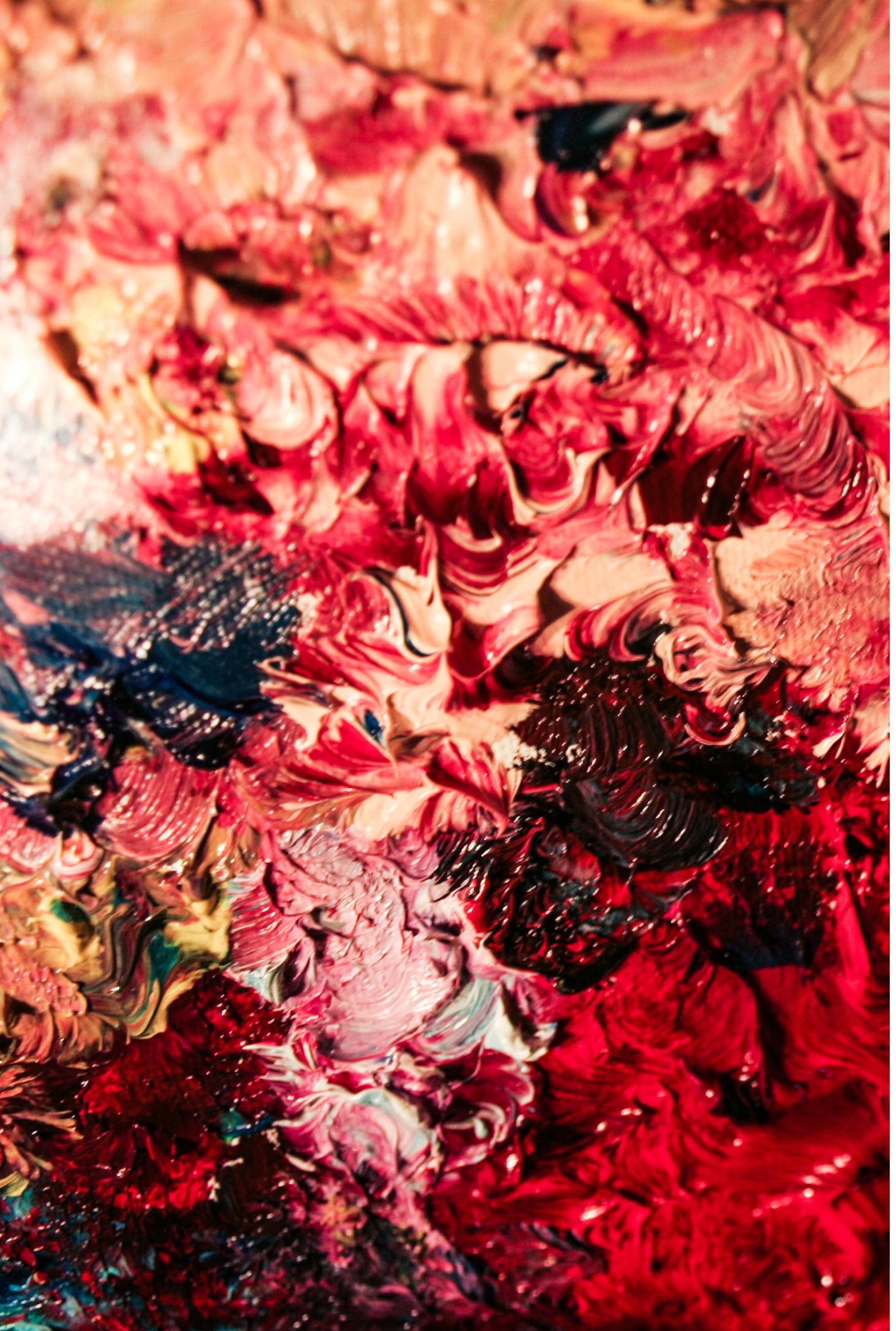


Hartfalen (HF) is een enorm maatschappelijk probleem en blijft de meest voorkomende doodsoorzaak wereldwijd. Het wordt gekenmerkd door een abnormale structuur en functie van de hartspier in rust en presenteert zich vaak met typische symptomen als kortademigheid, moeheid en oedeem. De huidige therapieën voor HF zijn voornamelijk ondersteunend en bestrijden enkel symtomen zonder dat ze daadwerkelijk de onderliggende pathophysiologische oorzaak aanpakken. Gezien HF een complex klinisch syndroom betreft dat zowel het pericardium, myocardium, endocardium, kleppen, bloedvaten en metabolisme raakt, is het vinden van nieuwe effectieve therapieën een uitdaging.

Dit proefschrift beschrijft het belang van de extracellulaire matrix op cardiale inflammatie gedurende de ontwikkeling van HF. Dit proefschrift benadrukt niet alleen dat glycoproteïnen en proteoglycanen belangrijke regulatoire functies vervullen in de extracellulaire ruimte, het beschrijft eveneens een verbreding van zijn bereik naar de bekleding van de bloedvaten ook wel bekend als de endotheliale glycocalyx. Bovendien toont dit proefschrift het belang van glycosylatie, een post-translationele modificatie die suikers (glycanen) aan de proteïne hangt, wat de functionele biologische variabiliteit van het proteïne immens vergroot. Dientengevolge vergoot de extracellulaire matrix zijn repertoire van louter behoud van de structurele integriteit, naar cel adhesie, signaal tranductie, immuniteit, embryologische ontwikkeling en het herkenning van pathogenen. De pathofysiologische bijdrage van gesecreteerde proteïnen osteoglycine, SPARC en semaphorine $3 \mathrm{~A}$ op de uitbreiding en handhaving van cardiale inflammatie als gevolg van virale myocarditis danwel myocard infarct wordt beschreven. Waar de voornaamste focus bij het bestuderen van extracellulaire matrix proteïnen haar rol in cardiale fibrose is geweest, vroegen wij ons juist af wat haar rol zou zijn op inflammatie in het hart. Omdat immuniteit de drijvende kracht is achter veel ziekten, hebben we hierbij gebruik gemaakt van twee modellen om dit te onderzoeken. Door te kijken naar zowel steriele alsook niet-steriele inflammatie hebben we getracht het mysterie van de extracellulaire matrix, een continue veranderende en diverse entiteit, op te helderen.

Allereerst leggen we uit wat de verantwoordelijkheden van het immuunsysteem zijn wanneer het in aanraking komt met bedreigingen van buitenaf. Nauwe relaties met zowel het cellulaire als extracellulaire compartiment zijn cruciaal voor het verschaffen van onmisbare informatie over deze 'bedreigingen' aan het imuun systeem. 
Hoofdstuk 2 bespreekt vervolgens de rol van de extracellulaire ruimte in het reguleren van belangrijke processen in het hart, zoals inflammatie en fibrose, die het gevolg zijn van weefselschade. Dit hoofdstuk beschrijft niet alleen de veelheid en variabiliteit van dit extracellulaire milieu, het benadrukt tevens zijn therapeutische mogelijkheden. De potentie van specifieke glycoproteïnen en proteoglycanen wordt vervolgens besproken in hoofstuk 3, 4 en 5. Hier tonen experimentele data het modulerende effect van drie individuele proteïnen op cardiale inflammatie in virus of ischemie geïnduceerde hartschade. Proteoglycan osteoglycine is belangrijk voor het verschaffen van informatie aan het immuun systeem via de 'patroon herkennings receptoren', en versterkt de immuun reactie. Verder laten we zien dat osteoglycine meerdere verschijningsvormen heeft als gevolg van glycosylatie. Deze verschillende verschijningsvormen zijn zijn gerelateerd aan een onderliggend pathofysiologisch proces. Glycoproteïne SPARC aan de andere kant blijkt cruciaal te zijn in de extracellulaire bekleding van de bloedvaten, de endotheliale glycocalyx. Hier reguleert het vasculaire permeabiliteit en de werving van leukocyten. We tonen dat een gebrek aan SPARC de microvasculaire glycocalyx in het hart ernstig beperkt waardoor zijn barriere functie wordt ontmanteld. Dit resulteert in een toename van inflammatie na virus geïnduceerde schade aan de hartspier. Tot slot hebben we het belang van een derde gesecreteerde glycoproteïne ontraveld, namelijk semaphorine $3 \mathrm{~A}$. Voor deze studie hebben we gebruik gemaakt van zowel een model van virale myocarditis als ook myocard infarct. We tonen dat semaphorine 3A inflammatie beïnvloed in beide modellen door immuun resolutie te promoten. Wijl werving van neutrofielen en monocyten cruciaal is in de vroege fase na weefselschade, is het tijdig opruimen van deze cellen onmisbaar voor adequate wondgenezing. Dit proefschrift laat zien dat semaphorine 3A specifiek de polarisatie van pro-inflammatoire M1 macrophages beïnvloed. Bovendien induceert het apoptose in enkel deze M1 macrophagen, zonder een effect te hebben op het meer anti-inflammatoire phenotype.

Samenvattend, presenteert dit proefschrift belangrijke functies voor gesecreteerde glycoproteïnen en proteoglycanen tijdens inflammatie in hartziekte. Deze fundamentele bevindingen vergroten niet alleen ons begrip van de ontwikkeling van hartziekten die kunnen lijden tot HF, het toont ook universele interacties van het immuun systeem met het extracellulaire milieu. Misleiding van het immuun systeem door pharmacologisch informatie afkomstig van de extracellulaire ruimte te overschrijven, zou de sleutel kunnen zijn naar de genezing van $\mathrm{HF}$. 


\section{INTRODUCTION}

Heart failure is a deadly disease affecting over 20 million people worldwide. This vast prevalence of heart disease looms the prevalence of cancer and presents a serious societal burden. Though we are currently striving to find new therapeutic strategies to treat heart failure patients, we are currently still struggling to understand the intricate changes that occur in the diseased myocardium in response to injury. Complete understanding of the intricate biology of the cardiac extracellular matrix in relation to heart failure development may prevail novel inputs to treat and cure this disease. In particular comprehending the close interaction of the cardiac extracellular matrix with the immune system as immunity is one of the driving forces behind adverse cardiac remodeling hence heart failure development.

In this thesis I demonstrate that the cardiac extracellular matrix is a very dynamic entity that is continuously changing and adapting towards its environment (Chapter 3 ). The constantly adapting appearance of the extracellular matrix is illustrated by small leucine rich proteoglycan Osteoglycin (Chapter 4) in myocardial infarction versus viral myocarditis. That extracellular proteins are vital for regulating tissue homeostasis is illustrated by the novel role of glycoprotein SPARC in the microvascular glycocalyx where it regulates cardiac inflammation (Chapter 5). Not only recruitment of immune cells can be controlled by the extracellular environment, also the clearance of inflammation is under control of the production of versatile extracellular glycoproteins and proteoglycans. Demonstrative of this is the influence of semaphorin $3 \mathrm{~A}$ on the clearance of pro-inflammatory M1 macrophages during myocardial infarct healing as illustrated in Chapter 6. This thesis therefore highlights novel imperative knowledge on how the ever-changing cardiac extracellular matrix regulates inflammation in cardiac disease.

\section{The Extracellular Matrix: my 'Heart' to Society}

Fundamental knowledge on versatile extracellular matrix proteins in relation to cardiac inflammation exhibits a novel platform for heart failure drug development. Though drug discovery is needed for improving the treatment of heart failure patients, unravelling all biological aspects of this disease entity proceeds in time. As a clinician I feel we should value the significance of fundamental research for this purpose. Creating knowledge without thinking about practical applications is what science is all about. The pursuit for complete understanding of human biology in health and disease is imperative for drug discovery. Indeed, where microRNAs have already disclosed a novel layer of biological complexity in cardiac disease in the early nineties thereby introducing a tremendous nursery for drug discovery, I believe this thesis suggests that the the ever-changing and versatile proteoglycans and glycoproteins residing in the extracellular matrix impose even greater therapeutic potential.

\section{SCIENCE COMMUNiCATION}

As a clinician and person I feel strongly about clear, open and vociferous communication on our fundamental scientific findings to a layman's audience. I feel the general public should be informed about the importance of fundamental biological discoveries in order to appreciate its relevance and value for the eventual drug discovery and development. If we can go on this 
quest together by increasing the commitment and involvement of society, the chance of finding that one cure for heart failure might be closer than we think. In this thesis I have tried to gather all the necessary expertise that was needed to unravel the intricacy of the studied proteins. Not only these collaborations but also conferences allow for attaining feedback from experts in the field on the obstacles one faces when unraveling the multifariousness of glycobiology. The feedback that I have received has helped me in formulating sharp hypothesis thereby facilitating the quest for answers. Fortunately this process work two ways as my presentations on conferences has also resulted in increased attention for the importance yet intricacy of glycobiology in the heart. This collective search for novel therapeutic strategies in cardiology is presented by this thesis and will hopefully aid heart failure drug development.

\section{The Extracellular Matrix: from Mice to Man}

Because the level of complexity of the extracellular matrix takes precedence over that of micro-RNA biology, unraveling the appearance of this ever-changing extracellular structure is challenging. Untying all players in the extracellular compartment and assigning individual value to each of them in the seemingly chaotic series of events that occur during disease, may help in finding an entrance to influence the outcome of the disease. However, where does one start with such an overwhelming endeavor. As we currently lack the technology to create biologically identical robots to mimic our human diseases, at present we still use animal models for this purpose. The fact that heart disease is a highly complex illness where many factor contribute to disease progression and outcome doesn't allow us to use cell culture or in silico calculation to study its pathophysiology. Nevertheless, we should strive for reducing and replacing the use of animals for scientific purposes by stimulating collaborations with researchers all over the world.

\section{Translation to other Fields}

While inflammation is a major contributor to cardiac disease development and progression, it is certainly nog exclusive to the myocardium. Indeed, one of the most intriguing aspects of studying inflammation is the multiplicity of the inflammatory mediators that are constantly being discovered, like microRNAs, adipokines, inflammasomes and the danger signals like extracellular glycoproteins and proteoglycans. Interestingly, their effect on target tissues seems very universal and numerous studies have demonstrated that inflammatory responses represent the 'common soil' of the multifactorial diseases, covering both chronic inflammatory rheumatic disorders as well as an extensive range of conditions including cardiovascular disease, neurodegenerative diseases, type 2 diabetes, obesity, asthma, ageing and cancer. Therefore, this thesis unravels novel inflammatory mediators that influence cardiac inflammation, hence are likely to involve general inflammatory responses.

\section{CONCLUSION}

Heart failure is a tremendous societal burden and current therapies are mainly supportive. Hence, there is real need for finding new therapeutic strategies. Where micro-RNAs have already opened the stage for novel drug discovery, extracellular glycoproteins and proteoglycans 
are an even greater nursery for heart failure drug discovery. Fundamental findings as described in this thesis are vital in this search. Not only in cardiovascular disease do extracellular glycoproteins and proteoglycans present novel treatment possibilities, numerous diseases could benefit the multiplicity of the novel inflammatory mediators described in this thesis. Finally, as a clinician, I would like to emphasize that this thesis shows that fundamental research is an inseparable keystone in drug discovery. 


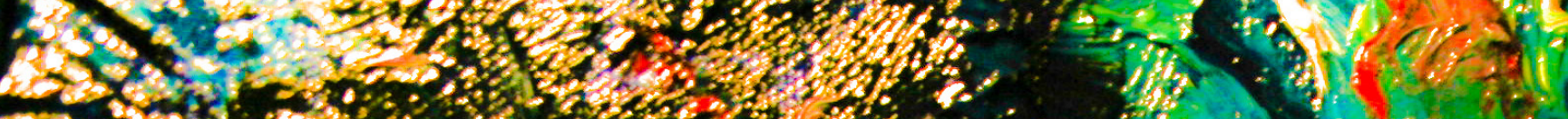

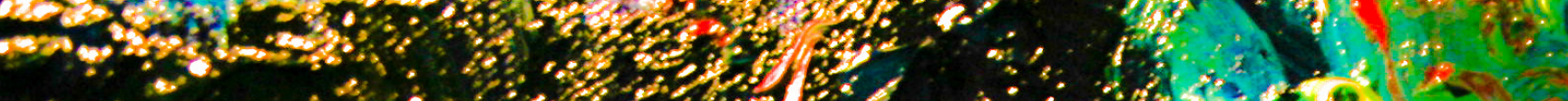

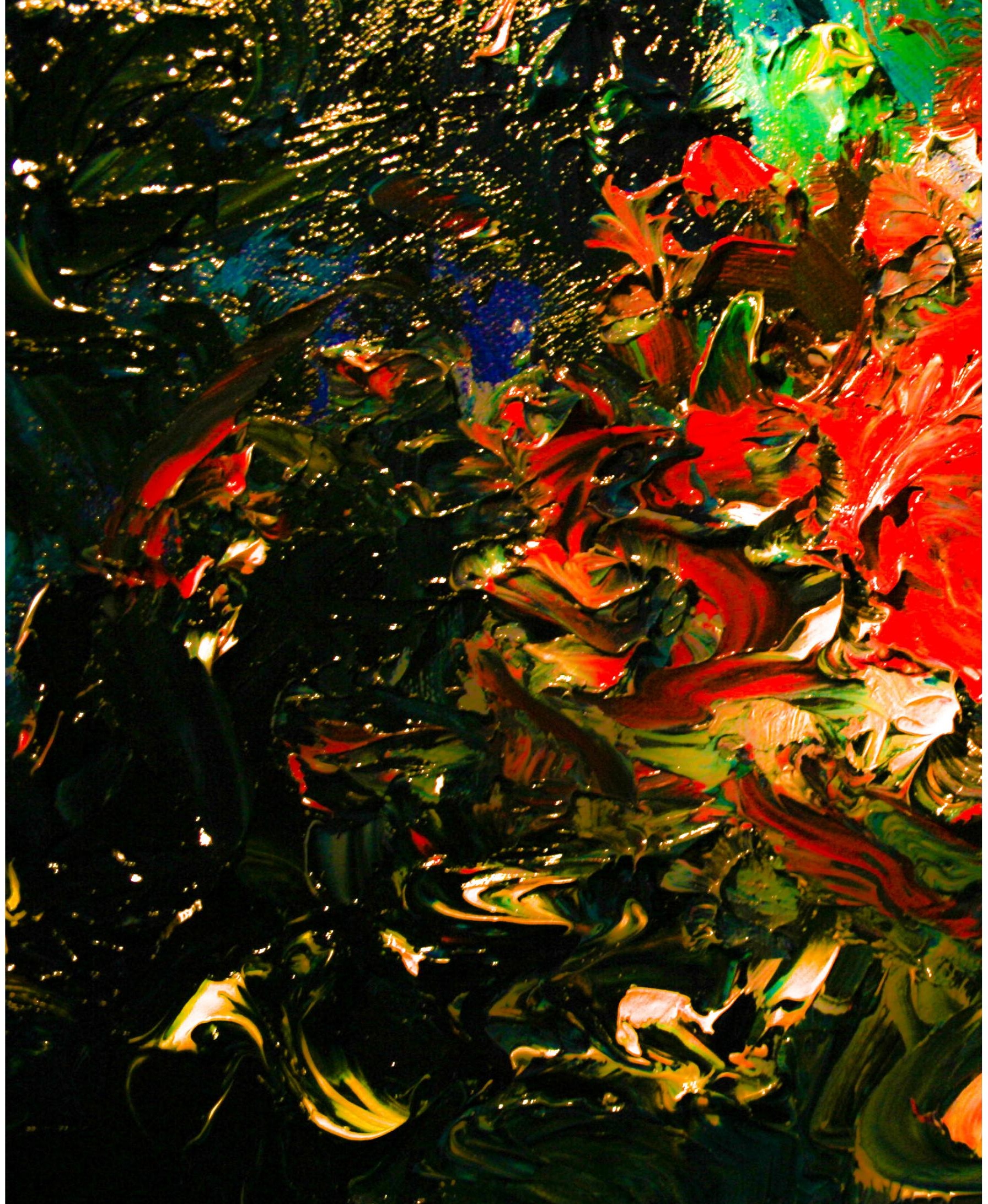




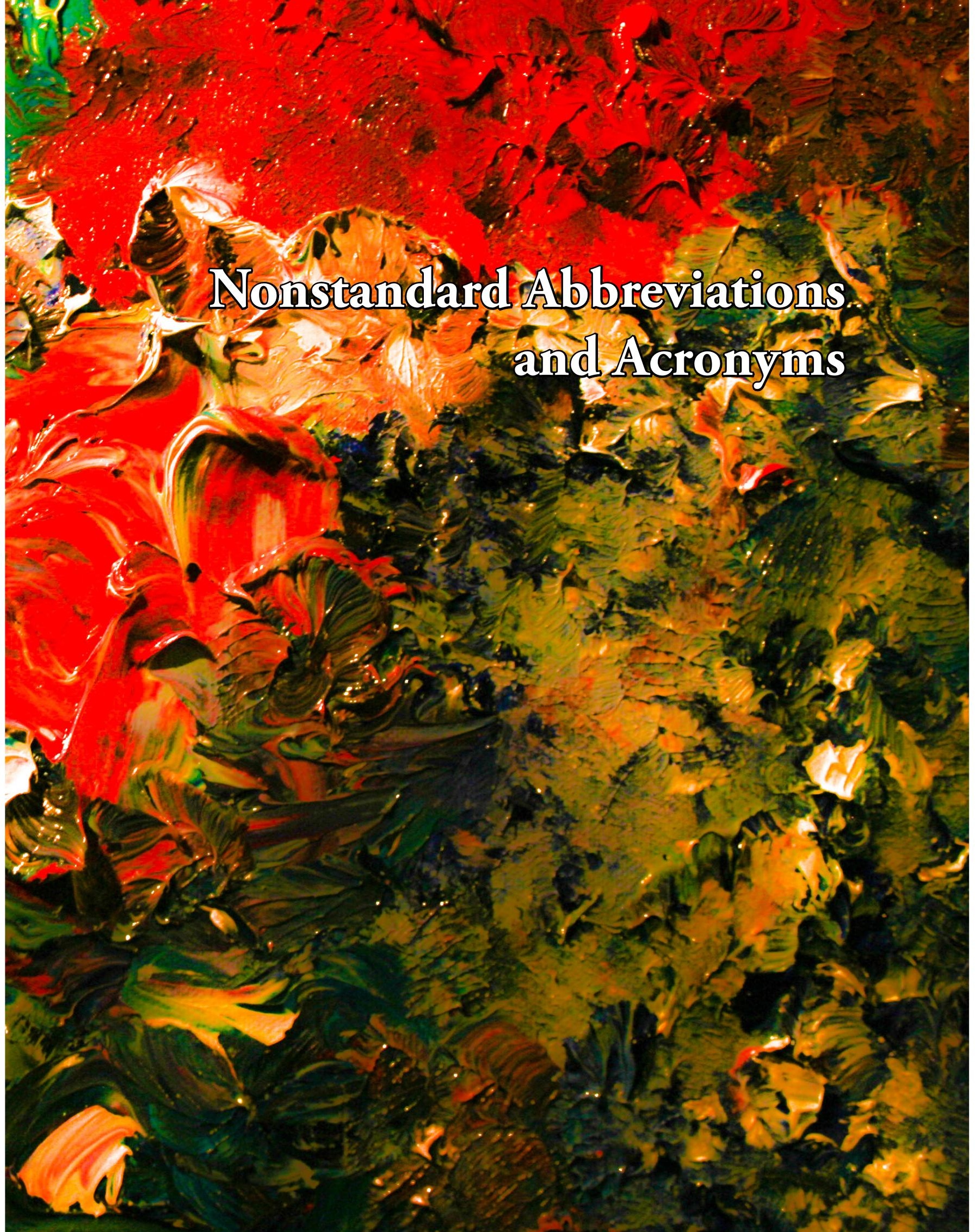




\begin{tabular}{|c|c|}
\hline $\mathrm{HF}$ & Heart Failure \\
\hline VM & Viral Myocarditis \\
\hline MI & Myocardial Infarction \\
\hline HEFpEF & Heart Failure with preserved Ejection Fraction \\
\hline HEFrEF & Heart Failure with reduced Ejection Fraction \\
\hline OGN & Osteoglycin \\
\hline SPARC & Secreted protein acidic rich in cysteine \\
\hline Sema3A & Semaphorin $3 \mathrm{~A}$ \\
\hline ECM & Extracellular matrix \\
\hline GAG & Glycosaminoglycan \\
\hline HS & Heparan sulfate \\
\hline CS & Chondroitin sulfate \\
\hline DS & Dermatan sulfate \\
\hline KS & Keratan sulfate \\
\hline ER & Endoplasmic reticulum \\
\hline MI & Myocardial infarction \\
\hline Ang & Angiotensin \\
\hline $\mathrm{I} / \mathrm{R}$ & Ischemia reperfusion \\
\hline TAC & Transaortic constriction \\
\hline $\mathrm{AB}$ & Aortic banding \\
\hline VM & Viral myocarditis \\
\hline AIM & Autoimmune myocarditis \\
\hline MMP & Matrix metallo protease \\
\hline FGF & Fibroblast growth factor \\
\hline TGF & Transforming growth factor \\
\hline TLR & Toll like receptor \\
\hline EGFR & Epidermal growth factor receptor \\
\hline IGFR & Insulin growth factor receptor \\
\hline LDL & low density lipoprotein \\
\hline SLRP & Small leucine rich proteoglycan \\
\hline TSP & Thrombospondin \\
\hline OPN & Osteopontin \\
\hline EXT1/EXT2 & Glucuronyl/N-acetylglucosaminyl transferases \\
\hline GlcNAc & $\mathrm{N}$-acetylglucosamine \\
\hline Xyl & Xylose \\
\hline GalNAc & $\mathrm{N}$-acetylgalactosamine \\
\hline Sia & Sialic acid \\
\hline Fuc & Fucose \\
\hline IdoA & Iduronic acid \\
\hline GlcA & Glucuronic acid \\
\hline Man & Mannose \\
\hline Gal & Galactose \\
\hline Glc & Glucose \\
\hline
\end{tabular}




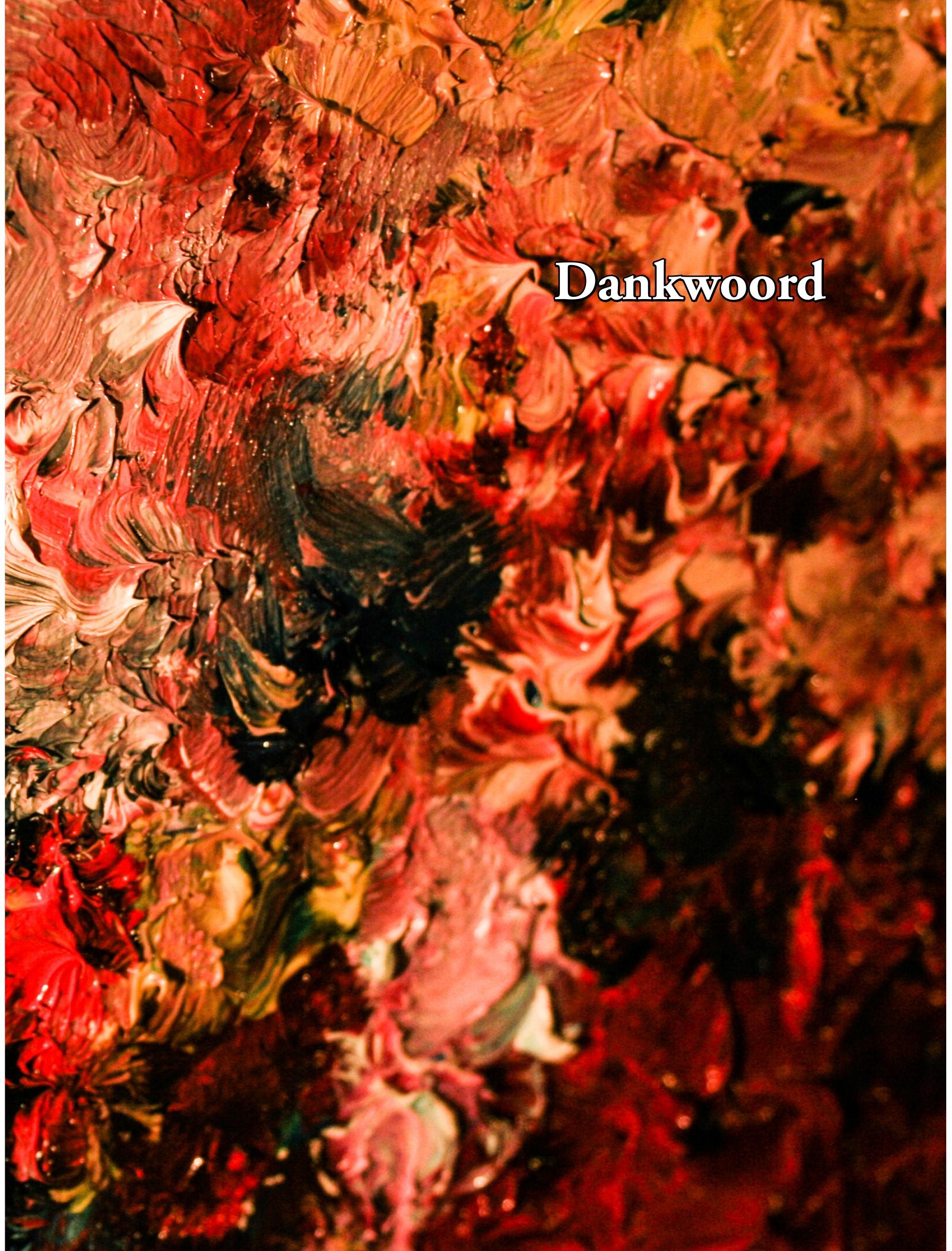


Promoveren is een beproeving. Een beproeving die je passie destilleert, je idealen in perspectief plaats maar vooral karakter bouwt. Geloven, volhouden, afzien maar vooral niet opgeven. Als jonge naïeve onderzoeker begon ik vol passie aan mijn ideaal, fundamenteel wetenschappelijk onderzoek. Het ideaalbeeld is wellicht wat verbleekt maar mijn passie is blijven bestaan. Inventief fröbelen in het lab gecombineerd met volhardende nieuwsgierigheid hebben bijgedragen aan dit proefschrift. Echter dit fröbelen had zonder de hulp van velen niet kunnen leiden tot mijn 'chef d'oeuvre'. Ik ben dankbaar voor de bijdrage van allen echter wil enkele personen in het bijzonder bedanken.

Beste professor Heymans, beste Stephane. Hoewel u als mijn promotor niet verantwoordelijk was voor mijn dagelijkse begeleiding ben ik u bijzonder dankbaar voor uw geloof in mij, mijn ideëen en mijn experimentele aanpak. Wat me van $u$ het meest zal bijblijven is uw tomeloze opportunisme. Ondanks dat uw pogingen tot omdenken soms met gevoelens van wanhoop werden ontvangen in het lab, is dit een kracht die ik bijzonder in u waardeer. Ik geloof inderdaad dat we tot alles instaat zijn als we maar geloven, volhouden en vooral niet opgeven. Een wijsheid die me hopelijk in mijn verdere wetenschappelijke carrière zal bijstaan. Bedankt voor al uw steun, vertrouwen en de kansen die u me heeft gegeven.

My dearest co-promotor, lieve Anna;) Ik heb het vaak gezegd maar ik had me echt geen fijnere co-promoter kunnen wensen. Niet alleen jouw aanstekelijke passie en nieuwsgierigheid hebben me enorm geïnspireerd, maar vooral bij jouw pragmatische, no-nonsense aanpak voelde ik me extreem comfortabel. Dat ons beider hart sneller gaat kloppen van mooi fundamenteel onderzoek werd me met name in Boston duidelijk. Jij bent voor mij wat in de Dikke van Dale bij 'wetenschapper' hoort te staan! ... naast Nahrendorf, Matzinger, Molkentin en Mayr natuurlijk:P Ik meen oprecht dat ik niet in woorden kan uitdrukken hoe bijzonder ik je waardeer. Ik wil je bedanken voor al je steun en vertrouwen. Ik hoop van harte dat we in de toekomst nog mooie dingen kunnen doen samen, zoals wellicht onze eerste Nature paper publiceren (dromen mag;-))

Mijn paranimfen Barbara en Eline. Lieve Babs, hier dan het hoofdstuk dat ik beloofd heb aan je te wijden;-) Wat was het altijd heerlijk dat ik ten alle tijden bij je binnen kon hupsen voor de ow zo nodige afleiding. Van heerlijk platte, flauwe grappen naar serieuze gesprekken over 'het leven' tijdens het drinken van koffie of het genieten van de culinaire mensa lunch, het kon allemaal. Ik waardeer je oprechtheid en hoop dat we contact blijven houden lieve Babs!! Fijn dat je achter me staat als paranimf. Lieve Eline, mijn klankbord en gouden afleiding tijdens deze jaren. Heerlijke fietstochtjes, geniale vakantie en altijd bereid om mijn onderzoeks belvenissen aan te horen, die jij overigens altijd perfect kon plaatsen. Ik ben dankbaar voor onze waardevolle vriendschap en trots dat je als paranimf achter me staat!

Lieve Paolo, dear Paolo. I still remember our first experiments in the dreadfulness of the old and haunted REGA-institute. We immediately had a relational fit and I have loved working with you since then. The most daunting memory I recall is the one where we had to do all the glycocalyx measurements. We were dressed as astronauts while sitting on reversed buckets in a $2 \times 2 \mathrm{~m} 2$ closet with no windows that we stuffed with too much expensive equipment, while I had to listen to you sing along to Kylie Minogue. The horror... how would I have ever survived if it wasn't for you? Thanks so much Paolo for not only being a great colleague these years but also for being a dear friend. 
Mijn overige leuke collegaatjes uit Leuven: Ward, Lucas en Sophie. Beste Ward, ik heb veel bewondering voor je ijzeren disipline en Vlaamse correctheid;-) Je bent een dierbare collega waar ik veel aan heb gehad. Dank voor de waardevolle discussies over alle genot en deugd van het lab. Ik weet zeker dat je een zeer succesvolle onderzoeker en clinicus zal zijn. We gaan elkaar tegenkomen!

Lucas, rasoptimest en mede-mimelecan gedupeerde. Wat heb ik onzettend met jou kunnen lachen. Je verfijnde zelfspot betreffende je memorabele presentatie op de ESC in Zweden, waar helaas niemand bij was om het na te vertellen;-), alsook onze mooie avond in de kroeg in Les Diableret. Je droge zwartgallige humor waren een balsem voor mijn beproefde geest en onze mimelecan-discussies hebben zondermeer bijgedragen aan nieuwe inzichten. Dank daarvoor. Lieve Sophie, niet alleen je bijstand bij mijn en onze gezamelijke projecten hebben me enorm geholpen maar ook onze gezellige weekendjes en stapavonden. Onder andere op de bruiloft van Paolo hebben we tot in de late uurtjes onze dansmoves getoond. Helaas arriveerde ik hierdoor wel iets laten dan gepland op het Matrix Biology congres de volgende dag, stomme Belgische treinen;-)

Aan mijn dagelijkse werkplezier hebben onder andere Wouter, Tim en Georg hun steentje bijgedragen. Van gezellige borrels in de Thembi's naar koffie drinken in de mensa. Derks, partner in crime die me verliet voor Dresden! Je jaloersmakende relaxte attitude werkte erg rustgevend. Een hardcore Bioloog die douchet met zijn mountainbike en al bierdrinkend de Cauberg beklimt, voor jou was niks te gek. Je bent een topcollega, dank voor alle mooie momenten. Tim, while you probably won't consider this a compliment, your envious attitude towards research to me exemplifies your Deutsche Gründlichkeit. While we did not use a similar approach workwise, we did fight the same battles a $\mathrm{PhD}$ student faces and there I truly found your support. You were always willing to help and listen when I needed it. Thanks so much for being a great colleague these years! George or Georg!! I really treasure the precious typical Georg moments I have experienced, like when you wore your 'Back off I am doing Science' shirt when you had to teach, or how you sniffled when you were presenting in the labmeeting after making a joke that nobody understood. That I have added phrases like 'freakishly awesome' to my vocabulary is all your merits. You really trained me in all the ins and outs of 'nerd-iness' which has truly enriched my life;-) I mean now I know why I should never wear red if I want to stay alive! But seriously Georg, thanks so much for everything, you rock!

Naast mijn directe $\mathrm{PhD}$ collega's wil ik uiteraard het fundament van het lab bedanken. Custers! Loze kreten en oergeluiden is hoe we met name met elkaar communiceerden, lekker lomp en primair. Ik vind je echt een top kerel en heb ontzettend fijn met je samengewerkt in het lab. Al moest ik je wel streng doch vriendelijk verzoeken tijdens het pipetteren even je mond te houden, dat gaat gewoon mis (remember;-))! In het bijzonder moet ik ook Rick en Wouter bedanken voor hun waardevolle lessen en alle antwoorden op mijn technische vragen. Wouter, ik heb je steun in het 'verdorven' instituut 'de academie' enorm gewaardeerd. Frustratie ging je te lijf met cynisme en sarcasme, ik hou ervan. Erg bewonder ik je grondigheid en ingenieuze ideëen die zijn tijd ver vooruit zijn, dus hou vol... die Nobelprijs is dichtbij! Rick, de western blot koning en mijn guru al deze jaren. Jij was de enige die mijn pijn begreep in het afscheid van de ouderwetse DOKA. De magie is er gewoon echt af... Ik ben je zeer dankbaar voor je hulp en begeleiding bij het ontrafelen van 'das mimecan mistery'.

Beste Jurgen. Ook jou wil ik bijzonder danken voor je begeleiding van mijn Cremaster experimenten. Je oprechte enthousiasme, meedenken en interesse hebben deze studie mede tot een succes gemaakt. Ook erg dankbaar ben ik Hanneke voor het aanleren van de 
ingewikkelde micro-chirurgischie ingreep. Al was ik in het begin jaloers op jouw prachtige Cremaster-preparaten, daar die van mij er nog redelijk gehavend uitzagen, door je geduld en behulpzaamheid ben ik er uiteindelijk in geslaagd om blind met 2 vingers in m'n neus die sinaasappel in dat neusgat te stoppen! Dank voor je heerlijke gevoel voor humor en de fijne samenwerking. Bart, ook jou wil ik natuurlijk bedanken voor al je hulp!

Naast al dat zwoegen in het lab is het ook erg belangrijk je werk te profileren op vooraanstaande wetenschappelijke congressen. Misschien nog wel veel belangrijker hierbij zijn de juiste congresmaatjes. And ow my! Waar ik in mijn eerste jaar met Corsten nog cultuur en wetenschap heb mogen snuiven in de prachtige steden les Diablerets en Ulm, hebben Hazebroek, Merken en misses Sanders voor nog meer memorabele momenten gezorgd in onder andere Athene en Sevilla. Dank voor deze fantastische en onvergetelijke herinneringen: goud! Maarten, jou wil ik in het bijzonder bedanken voor je oprechte interesse en enthousiasme in mijn gestuntel in het lab, je was een top collega en bent een waardevolle vriend.

Ook Blanche, Marc, Geert, Laura, Robin, Monika, Lilian en Steffie wil ik bedanken voor alle werkplezier afelopen jaren. Daarnaast heeft de open samenwerking in het groot cardiolab een rijke omgeving geboden om mijn ervaring op te doen. Mijn dank gaat hierbij onder andere uit naar Leon, Paula, Servé, Natasja, Rio, Burçu, Ellen, Ella en Nicole. Tenslotte mijn dank aan alle indirecte collega's die hebben bijgedragen aan mijn werk afgelopen jaren. Freek, Nynke, Daniel, de medewerkers van het CPV waarbij in het bijzonder Richard en Paulien. Verder natuurlijk dank aan Mark Schellings, die het wetenschappelijke vuur in mij als jonge student heeft aangewakkerd.

Niet alleen mijn collega's op de werkvloer zijn bepalend geweest voor mijn leven in de krochten van de Universiteit, eenmaal daglicht aanschouwend heeft de steun van velen me bij tijd en wijlen opmerkzaam gemaakt voor de betrekkelijkheid van mijn werk. Cruciaal en verfrissend, het heeft me scherp gehouden. Mijn dierbare vriendinnen Hanne, Rikst en Martine wil ik met name danken hiervoor.

Graag wil ik ook Prof. dr. C. Schalkwijk, Prof. Dr. T.M. Hackeng, Prof. dr. M. Mayr, Prof. dr. M.J.Th.H. Goumans en Dr. P. van Paassen voor het beoordelen van dit proefschrift.

En dan tot slot mijn dierbare familie. Ook al hebben jullie volgens mij nooit ècht begrepen wat ik heb uitgespookt al die jaren, bedankt voor al jullie steun. Geert, jou wil ik in het bijzonder bedanken voor je onvoorwaardelijke steun als mijn rots in de branding gedurende deze jaren. Ik ben je ontzettend dankbaar voor je vertrouwen en geloof in mij en mijn kunnen.

\section{Marieke RienKs \\ MAASTRICHT, FEBRUARI 2016}




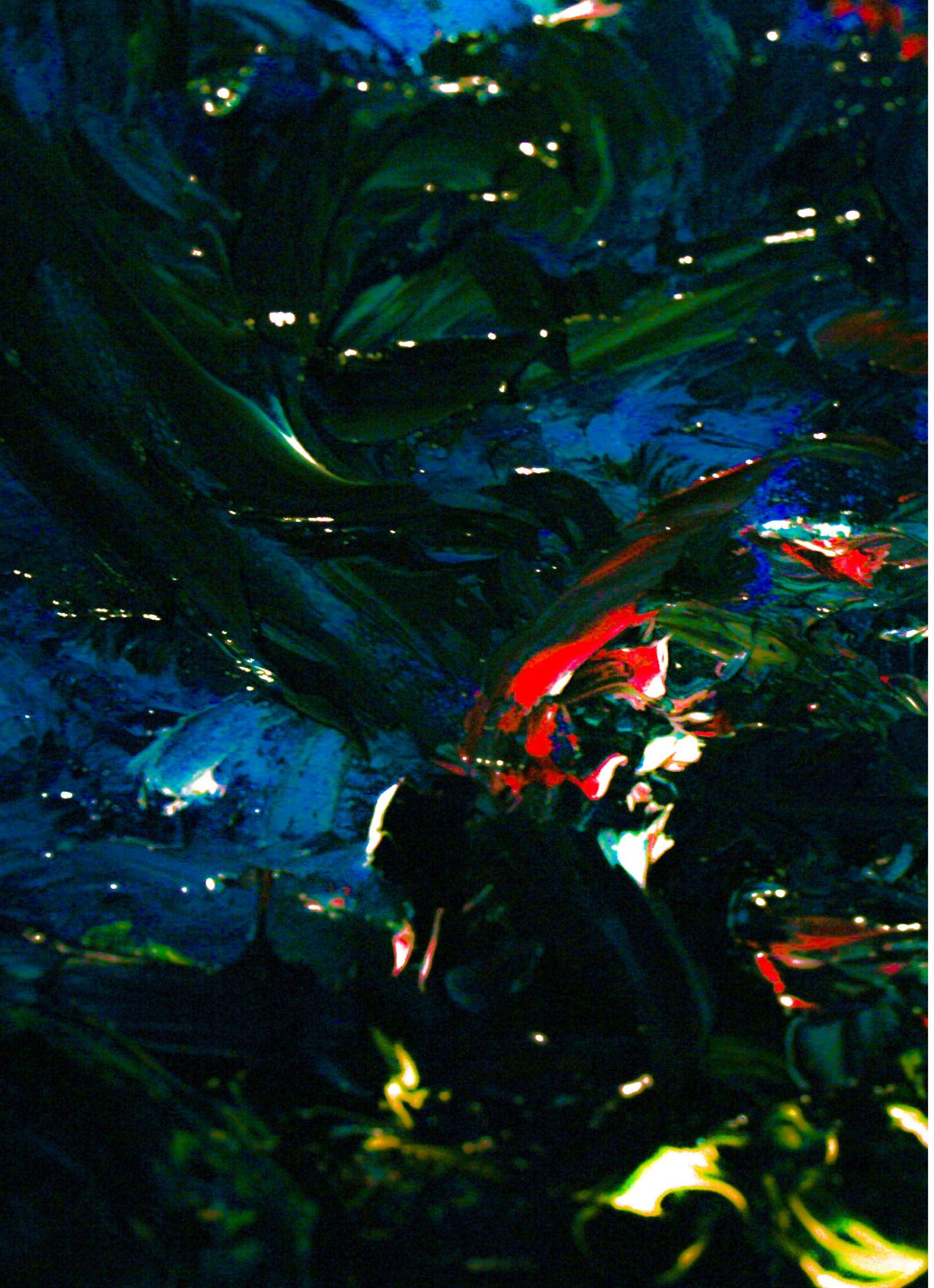




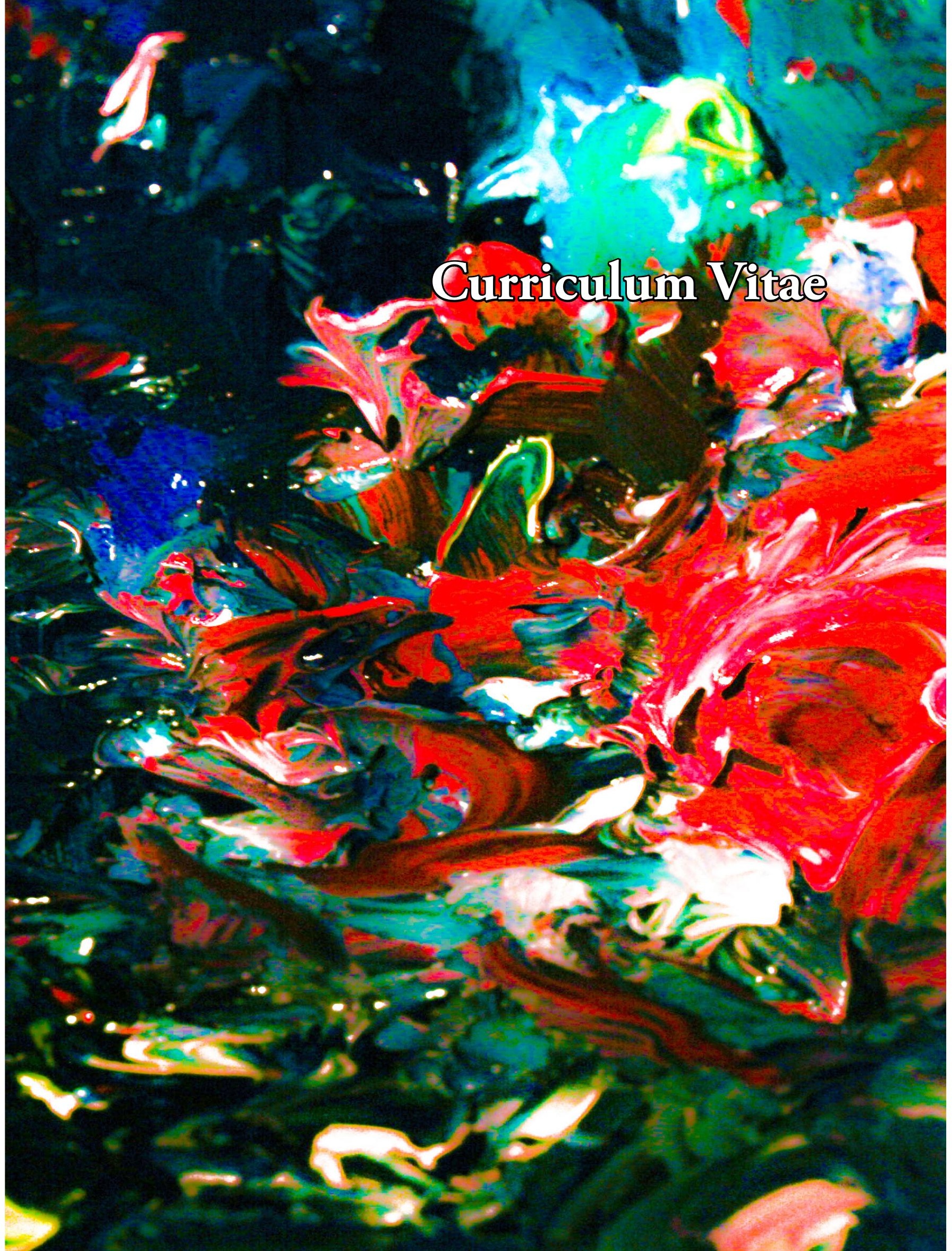


Born in Leeuwarden, the Netherlands, Marieke completed her Master in Medicine in 2010 at Maastricht University where she did her clinical internships in both academic and regional hospitals in the Netherlands. Marieke' first contact with scientific research was in the third year of her Medical training were she volunteered as a student assistant in the department of Neurosurgery and Anesthesiology, which led to a poster presentation at the 'International Anesthesia Research Society Conference' in 2008 in San Francisco. Her interest and passion for molecular biology became increasingly clear during her following internships, which convinced her in pursuing a PhD position in Basic Research after graduation. Her interest for Cardiology and Internal Medicine led to an application in the lab of Professor Heymans, were she focused on the role of matrix proteins in inflammatory cardiomyopathies. During her $\mathrm{PhD}$ she was awarded for oral (poster) presentations such as the Young Investigators Award at the Dutch German joint meeting, the Young Investigators Award at the Heart Failure meeting, best thematic poster at the Experimental Biology meeting and best parallel presentation at the third Cardiovascular Conference. Furthermore she was nominated for the project Faces of Science of the Royal Netherlands Academy of Arts and Sciences and de Jonge Akademie, in collaboration with Kennislink, were she discussed her live, her research and her passions. By writing a blog on lab animal science for Faces of Science, she was asked by the Stichting Informatie Dierproeven or SID to help promote honest and open communication about lab animal science as a board member. She finished her research in juli 2015 and is currently working as a resident specializing in Internal Medicine at the Jeroen Bosch hospital in 's Hertogenbosch. 


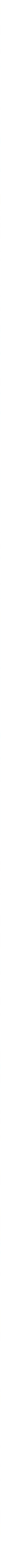



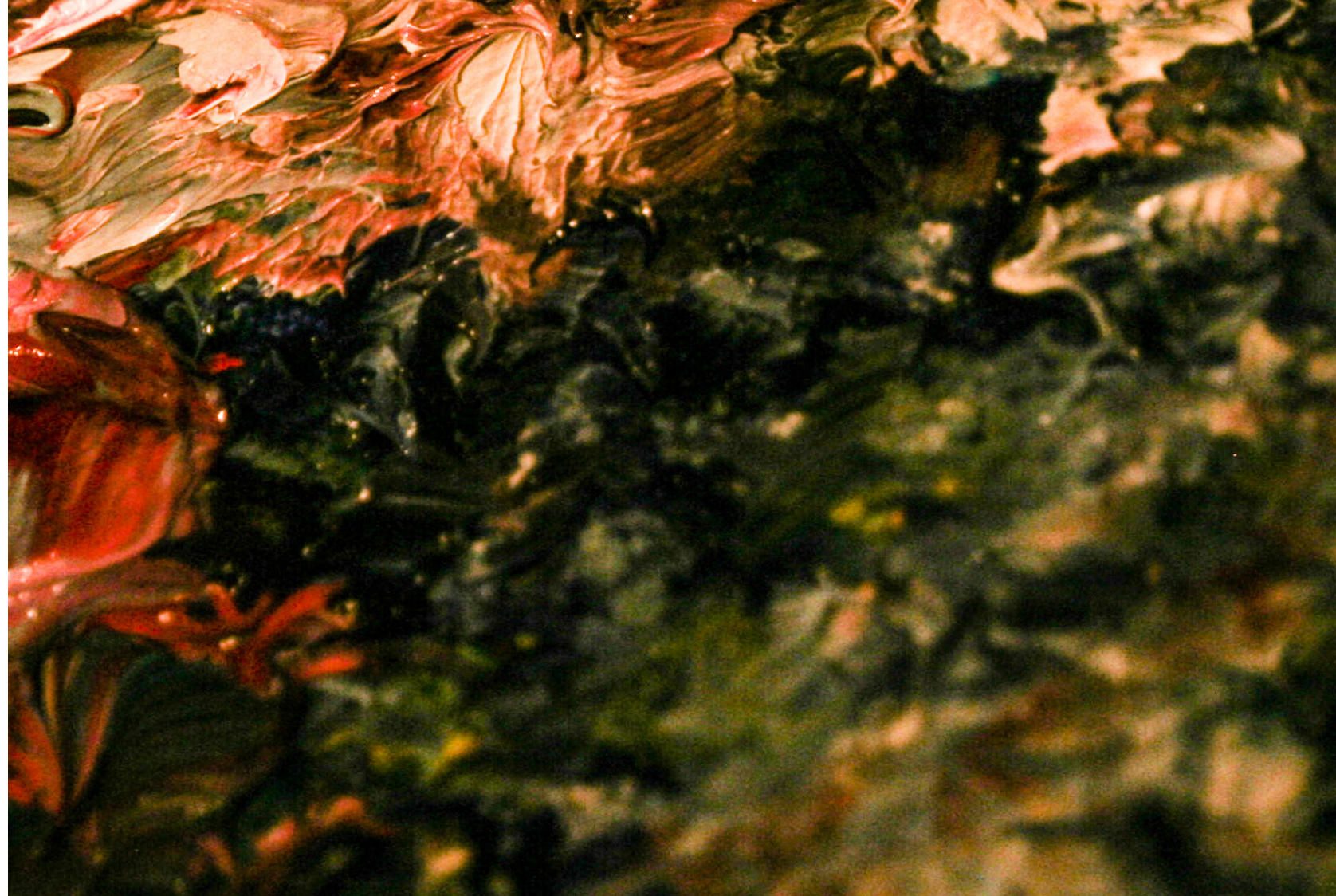
Marieke Rienks, Anna-Pia Papageorgiou, Nikolaos G Frangogiannis and Stephane Heymans. The Myocardial Extracellular Matrix: An ever changing and diverse entity. Circulation Research 2014; 114: 872-888

Marieke Rienks, Elizabeth A Jones, Jurgen van Teeffelen, Paolo Carai, Bart Eskens, Wouter Verhesen, Bianca Hemmeryckx, Rick van Leeuwen, Stephane Heymans*, Anna-Pia Papageorgiou* (* contributed equally). The extracellular matrix protein SPARC is crucial in maintaining endothelial barrier function and prevents adverse cardiac inflammation. (under revision)

Marieke Rienks, Anna-Pia Papageorgiou. Novel regulators of cardiac inflammation: Matricellular proteins expand their repertoire. Journal of Molecular and Cellular Cardiology. (accepted with minor revisions)

Anna-Pia Papageorgiou*, Ward Heggermont*, Marieke Rienks, Paolo Carai, Lies Langouche, Wouter Verhesen, Rudolf De Boer, Stephane Heymans. (*contributed equally) Liver X receptor activation by T0901317 enhances CVB3 viral replication during myocarditis by stimulating lipogenesis. Cardiovasc Res. 2015 Jul 1;107(1):78-88. doi: 10.1093/cvr/cvv157. Epub 2015 May 21.

Marieke Rienks, Anna Papageorgiou, Wouter Verhesen, Rick v. Leeuwen, Paolo Carai, Dirk Westermann, Stephane Heymans. The chondroitin sulfate variant of Osteoglycin increases cardiac inflammation upon viral myocarditis by direct stimulation of the Toll Like Receptor 4. (submitted)

Marieke Rienks, Paolo Carai, Mark Schellings, Johan Verjans, Leo Hofstra, Stephane Heymans, Anna Papageorgiou. Semaphorin $3 A$ promotes clearance of classically activated macrophages and the resolution of inflammation during myocardial infarction. (submitted) 